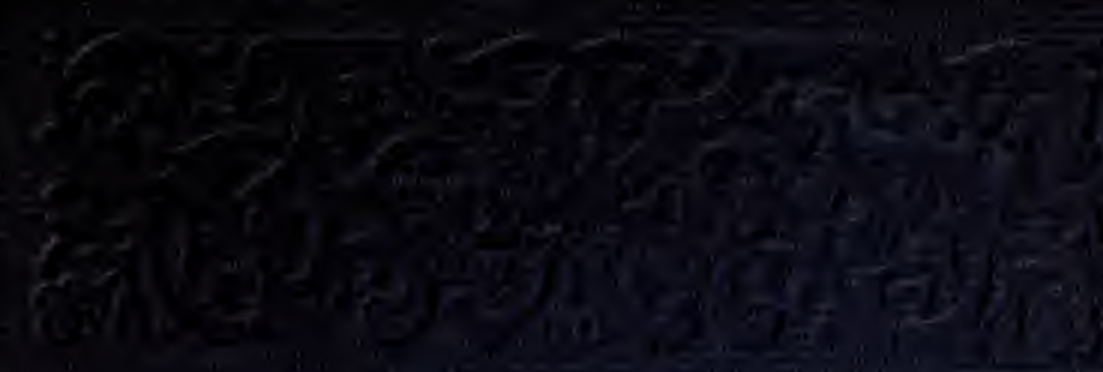

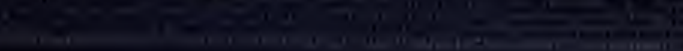

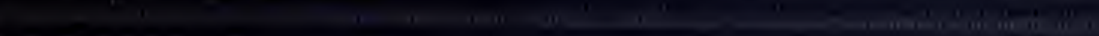

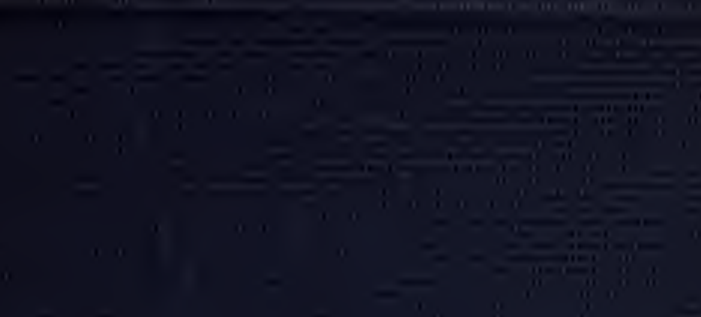



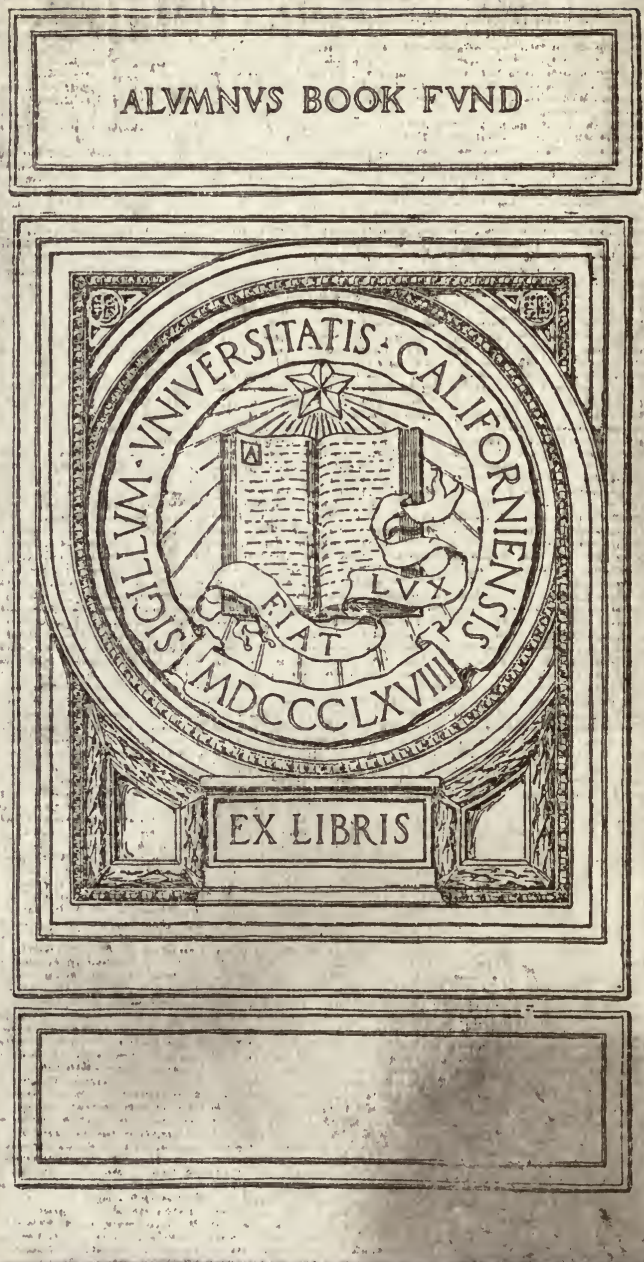



\section{T H E \\ COMMERCIAL PRODUCTS \\ OF THE SEA; \\ OR,}

MARINE CONTRIBUTIONS TO FOOD,

INDUSTRY, AND ART.

By P. L. SIMMONDS,

EDITOR OF "THE JOURNAL OF APPLIED SCIENCE," AUTHOR OF "ANIMAL PRODUCTS AND THEIR USES," "A DICTIONARY OF TRADE PRODUCTS," "TROPICAL AGRICULTURE,"

AND OTHER WORKS.

NEW AND CHEAPER EDITION.

WITH THIRTY-TWO ILLUSTRATIONS.

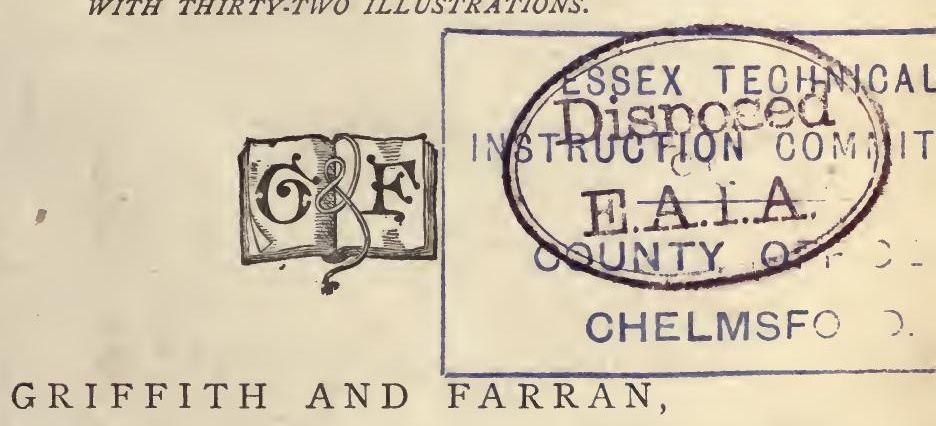

WEST CORNER OF ST. PAUL'S CHURCHYARD, LONDON.

E. P. Dutton \& Co., New York. 


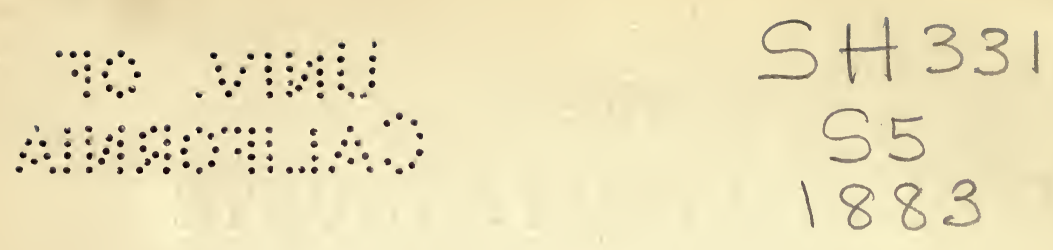

An Alumni

(The rights of translation and of reproduction are reserved.) 


\section{PREFACE.}

Having published a series of papers in the Art Fournal, under the title of "Marine Contributions to Art," and some other articles on various products obtained from the Sea in my serial publications, The Technologist and The Fournal of Applied Science, it occurred to me that they might be conveniently collected into a volume, which would form a companion to books I had previously published on "The Commercial Products of the Vegetable Kingdom," and on "Animal Products: their Preparation and Uses." Hence the appearance of the present work, which, I believe, will supply a want, by furnishing accurate details respecting articles and products of considerable importance in a commercial point of view.

Although some works have been published from time to time on special fisheries, none have treated the subject as a whole, or gone over the field of research in a systematic manner, so as to show the importance of the Commercial Products of the Sea to various countries. I have endea- 
voured to bring down the official statistics in the several chapters to the latest date, and therefore I trust the work may be found a useful and readable handbook for all those interested in marine productions.

While I do not claim any merit for originality in this book, I may state that I have taken every pains to consult all published documents treating on the subject that have come under my notice, especially those issued in the United States and on the Continent, and also the official publications printed by different Governments.

As the book professes to deal only with the Products of the Sea, I have necessarily had to exclude much interesting matter relating to the River and Lake Fisheries of various countries.

\section{P. L. SIMMONDS.}

29, Cheapside, London, October, 1878 .

\section{PUBLISHERS' NOTE TO THE SECOND EDITION.}

THE widespread interest excited by the International Fisheries Exhibition has induced us to issue a New and Cheaper Edition of this work, which has already taken its place as a valuable collection of facts concerning marine contributions to food, industry, and art.

The vast importance of our marine harvests, practically shown in the great Exhibition of 1883 , is permanently recorded in the pages of this volume, which does for the library what the Exhibition does for the eye, viz. presents a complete survey of the commercial products of the sea. 


\section{CONTENTS.}

PAGE

General Introduction

\section{-.. $\quad$.. \\ PART I.} CHAPTER

FOOD PRODUCTS OBTAINED FROM THE SEA.

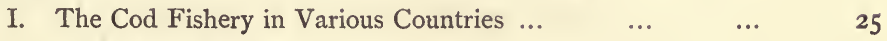

$\begin{array}{llllllll}\text { II. The Herring Fishery } & \ldots & \ldots & \ldots & \ldots & \ldots & 4 \mathrm{I}\end{array}$

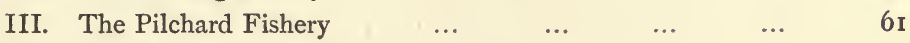

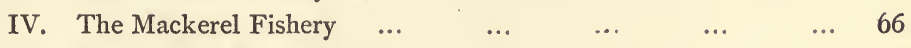

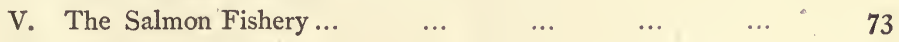

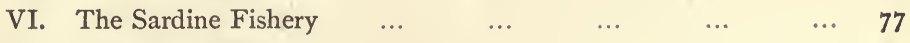

VII. The Tunny Fishery $\ldots \begin{array}{lllllll}\ldots & \ldots & \ldots & \ldots & \ldots & 83\end{array}$

$\begin{array}{lllllllll}\text { VIII. Crustacea } & \ldots & \ldots & \ldots & \ldots & \ldots & \ldots & 90\end{array}$

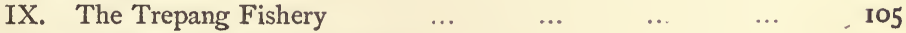

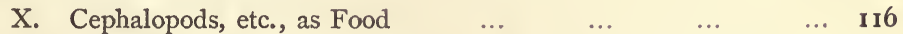

$\begin{array}{lllllllll}\text { XI. Miscellaneous Fisheries } & \ldots & \ldots & \ldots & \ldots & 127\end{array}$

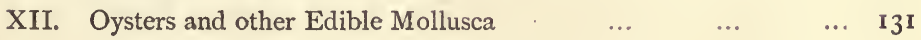

\section{PART II.}

MARINE CONTRIBUTIONS TO INDUSTRY.

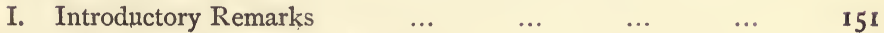

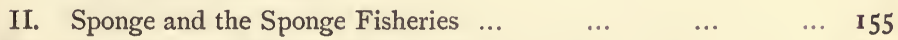

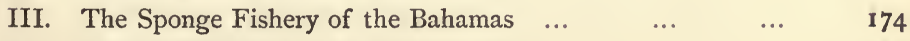

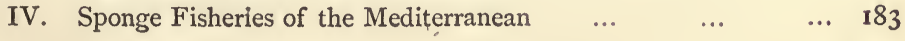


CHAPTER

$\begin{array}{llllllll}\text { V. Oils from Marine Mammals } & \ldots & \ldots & \ldots & \ldots & 198\end{array}$

VI. Fish Oils and the Fisheries connected therewith $\quad \ldots \quad \ldots \quad 212$

VII. The Shark Fishery for the Oil obtained $\quad \ldots \quad \ldots \quad \ldots \quad 226$

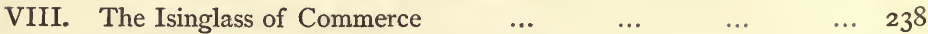

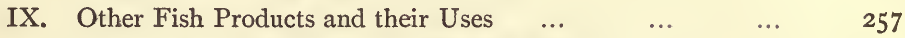

$\mathrm{X}$. Industrial and Manufacturing Uses of Shells $\quad \ldots \quad \ldots \quad 267$.

XI. Industrial and Manufacturing Uses of Shells-Continued ... 288

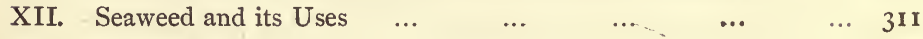

$\begin{array}{llllllll}\text { XIII. Marine Salt } & \ldots & \ldots & \ldots & \ldots & \ldots & 339\end{array}$

\section{PART III.}

MARINE CONTRIBUTIONS TO ART.

I. Tortoiseshell and the Turtle Fisheries $\quad \ldots \quad \ldots \quad \ldots \quad 35^{1}$

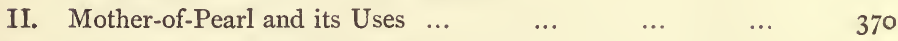

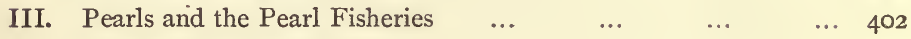

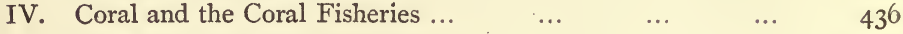

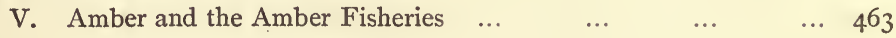

$\begin{array}{lllllllll}\text { INDEX } & \ldots & \ldots & \text { :. } & \ldots & \ldots & \ldots & \ldots & 479\end{array}$ 


\section{LIST OF ILLUSTRATIONS.}

FIG.

PAGE

Coal-Fish

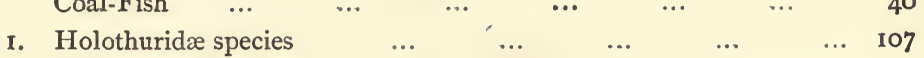

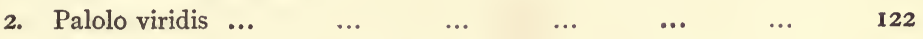

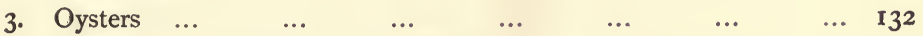

4. Sponge showing the Outgoing Water-currents $\quad \ldots \quad \ldots \quad$ I56

5. Outer Surface of different kinds of Sponge $\quad \ldots \quad \ldots \ldots 6$

6. Cup-shaped Sponges in natural position, rooted to rock $\quad \ldots \quad$ I69

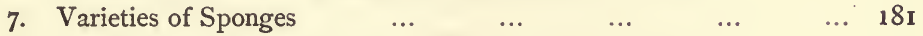

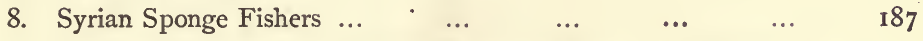

9. Silicious Sponges. I. Euplectella aspergillum. 2. Holtenia car$\begin{array}{lllllll}\text { penteria } \quad \ldots & \ldots & \ldots & \ldots & \ldots & \ldots & \text { I94 }\end{array}$

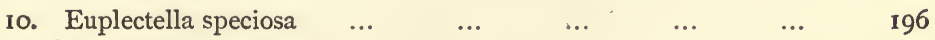

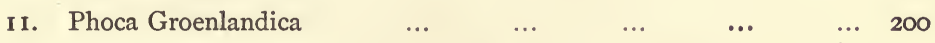

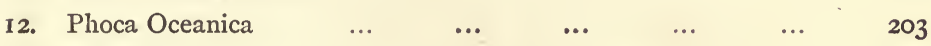

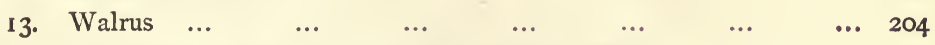

14. Greenland or Right Whale, and Spermaceti Whale ... ... 206

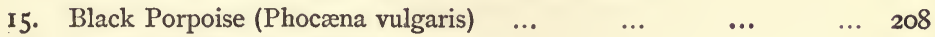

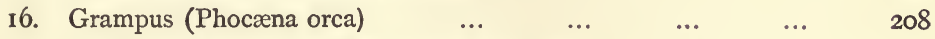

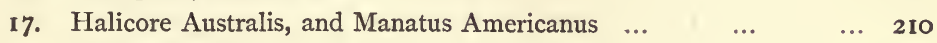

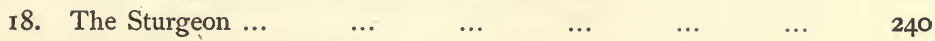

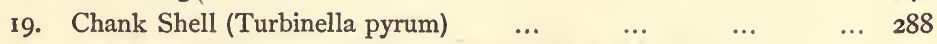

20. Saw used by Natives for cutting Segments of the Shell $\quad . . \quad 290$

21. Segment of Shell, and Bangle, or Ornamented Bracelet of United $\begin{array}{lllllll}\text { Segments } \ldots & \ldots & \ldots & \ldots & \ldots & \ldots & 29 \text { I }\end{array}$

22. I. Money Cowry. 2. Ovulum angulosum. 3. Dentalium Shell (Money of West Coast Indians). 4. Fillet of Nautilus Shells $\begin{array}{lllllll}\text { (from Samoa) } & \ldots & \ldots & \ldots & \ldots & \ldots & \end{array}$ 


\section{List of Illustrations.}

FIG. PAGE

23. Pinna nobilis, and Pinna rugosa $\ldots \begin{array}{llllll} & \ldots & \ldots & \ldots & \ldots & 307\end{array}$

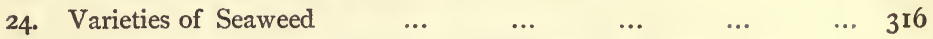

25. Ulva latissima (Green Sloke), and Chondrus crispus (Carrageen

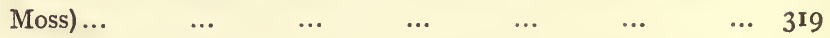

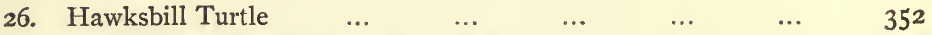

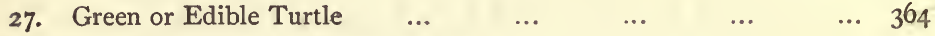

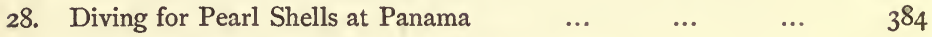

29. Mother-of-Pearl Shell, and Anodonta herculæ ... $\quad \ldots \quad$ 4II I

30. Corallium nobilis, or red Coral, with a piece magnified, showing $\begin{array}{llllllll}\text { the Polypes } & \ldots & \ldots & \ldots & \ldots & \ldots & \ldots & 437\end{array}$

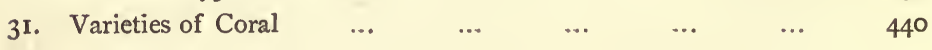




\section{THE COMMERCIAL PRODUCTS OF THE SEA.}

\section{GENERAL INTRODUCTION.}

Importance of marine products-Uses of the animals-Number of species of fishes-French bounty on fisheries-Statistics of British fisheries-Fish - as an article of food-Definition of "prime" and "offal" in the London market-Quantity of fish brought to London-Value of fish and other marine products imported-Value of exports-Statistics of British, French, and North American fisheries-French fisheries, and consumption of fish in Paris-Value of the trade in fish in foreign countries.

THE commercial products obtained from the sea are more numerous and important than would be generally supposed by those who have not looked closely into the subject. The huge marine mammals furnish us with valuable oil, skins, whalebone, spermaceti, ambergris, etc., as well as food to some tribes. The utility of fishes, properly so called, to man is not very various. For the most part, they serve only as food; but in this respect they are of the utmost importance to a great part of the human race, who live only on this class of animals. Some savage nations possess the art of preparing fish in a great variety of ways, even as a kind of flour and bread. Fish are also salted and 
dried, smoked and potted, preserved in oil, and pounded into a dry mass.

In Catholic countries the consumption of fish during their fasts and festivals is very large ; all other food being then prohibited by their priests.

To a great part of the civilized world the taking of the herring, the pilchard, the mackerel, the cod, the tunny, the salmon, the sardine, and other fishes is of great value, and gives employment to many hundreds of persons. The oil obtained from the shark, cod, herring, and other fish is used for lamps, medicine, and in industry. Many parts of fish are employed in the arts and manufactures-as the scales of the bleak for making false pearls, and those of other fish for making ornaments; the skins for tanning and other purposes. Isinglass is obtained from the air or swimming bladders of many. Fish roes are not only used as food delicacies, but also for bait in the fishing grounds. Fish maws, shark's fins, and bèche-de-mer or trepang (a species of Holothuria) are considered great food delicacies by the Chinese, forming the chief ingredients for their gelatinous soups.

The sea is more abundantly stocked with living creatures than the land. In all parts of the world a rocky and partially protected shore perhaps supports, in a given space, a greater number of individual animals than any other station. The sea is filled with animals of several kinds, and each layer of water in depth seems to have its own varieties, thus resembling the changes which take place according to elevation in the organized portions of the land.

The animals are among the mightiest and among the smallest. There are swimming beasts, as whales, seals, and walruses; there are fishes of various kinds and sizes, 
crustaceans, soft or jelly fishes, the molluscs, down to those creatures resembling live plants-the zoophytes or corallines, which partake of the qualities of plant, animal, and mammal. All these are peculiar to the sea or the fresh waters; and the ocean has its marine plants-seaweeds, which remain growing on the ground shoals, or rise to the surface and then float. These, too, have many useful or economic applications.

It is not our purpose to speak of the inhabitants of the ocean generally, but only to restrict the investigation to those which are of some use to man.

Pliny enumerated but 94 species of fish; Linnæus increased the number to 478 ; but recent naturalists have described over I3,000 species, one-tenth of which confine themselves to the fresh waters.

The human race derives almost incalculable benefits from them, as is evidenced by the extent and value of the river, coast, and sea fisheries of the world.

The sea, as Commander Maury well observes, has its offices and duties to perform. So may its inhabitants ; consequently he who undertakes to study its phenomena must cease to regard it as a waste of waters. He must look upon it as a part of the exquisite machinery by which the harmonies of nature are preserved, and then he will begin to perceive the developments of order and the evidence of design, which make it a most beautiful and interesting subject for contemplation.

The harvest of the sea has not yet been attended to and garnered to the same extent as the land. Some nations, as the Chinese, have, it is true, long given close attention to the profitable utilization of its commercial products, and several European nations and the Americans have also prosecuted certain fisheries; but systematic 


\section{4 \\ The Commercial Products of the Sea.}

and scientific management has only of late years been specially directed to the various branches which have been termed pisciculture, aquiculture, and ostreiculture, and the transfer of the fishes of one locality to those of another district.

In respect of fish, no natural cause prevents their coexistence in the greatest abundance with man in his highest state of civilization and refinement, in the midst of the greatest agricultural or manufacturing opulence.

Easily scared in the first instance by unusual sightsfor it has been proved, by a series of curious and interesting experiments on the trout, that most kinds of fish are insensible to sounds-the natives of the water are speedily reconciled to appearances, which become habitual when found to be connected with no danger.

By all civilized and commercial nations-especially the Dutch, the English, the Americans, and the Frenchthe products of the sea have been accounted fully as important as those of the land; because they not only afford cheap, nutritious, and abundant food for the people, but contribute largely, moreover, to the national resources, and to the maintenance of a maritime ascendancy. The Americans and French offer bounties to their fishermen, which of course tells against the fisheries in British America.

France pays about 540,000 francs a year, averaging about $£ 2$ to each man engaged in the fishery. This is an expensive process, but it is alleged that it would cost twice as much to train an equal number of men for the navy in any other way. In I86I a French commission, appointed to inquire into the deep-sea fisheries, said in their report, "It is on fisheries that at this day repose all the most serious hopes of our maritime enlistments," and it was 
added that "no other school can compare with this in preparing them so well, and in numbers so important, for the service of the navy." These bounties are also defended on the ground that the French pursue the cod fishery at a great disadvantage of distance, and from having no possessions in the neighbourhood except two rocky islets.

The fishery question is of urgent consequence to the people generally. Our population is increasing rapidly; cities and towns are gradually covering fields which used to be available for agriculture ; and although steam-farming is increasing the efficiency of husbandry labour, it cannot possibly augment the supply of home-grown food so rapidly as the bread-eaters increase in number. Fish is among the articles of diet which are too little familiarized among us, and any information ought to be welcomed which increases our knowledge of fishing grounds within reach of England.

That the supply of fish is most abundant, and indeed inexhaustible, on all our coasts, has never been called in question. "The coasts of Great Britain," says Sir John Boroughs, "doe yield such a continued sea-harvest of gain and benefit to all those that with diligence doe labour in the same, that no time or season in the yeare passeth away without some apparent meanes of profitable employment, especially to such as apply themselves to fishing; which from the beginning of the yeare unto the latter end, continueth upon some part or other of our coastes, and these in such infinite shoales and multitudes of fishes are offered to the takers, as may justly move admiration, not only to strangers, but to those that daily bee employed amongst them." That this harvest, ripe for gathering at all seasons of the year, without the labour of 
tillage, without expense of seed or manure, without the payment of rent or taxes, is inexhaustible, the extraordinary fecundity of the most valuable species of fish would alone afford abundant proof.

In spite, however, of this large supply of wholesome, palatable, and nutritious food, yielded by the surrounding seas of Great Britain, every acre of which is infinitely more productive than the same quantity of the richest land; notwithstanding that these salt-water fields are perpetually "white to the harvest," it is a remarkable fact that, in the inland and middle counties of England, the labouring classes scarcely know the taste of fish, which of late years has become a scarce article, even in some of the maritime counties. Formerly salmon, whilst in season, was the common food of all ranks in the northern counties bordering on the sea, and in most parts of Wales, and what could not be used fresh was salted for winter consumption; there was scarcely a family in the neighbourhood of a seaport or salmon fishery that did not lay up a supply of pickled salmon for the winter.

The produce of the sea around our coasts bears a far higher proportion to that of the land than is generally imagined. The most frequented fishing grounds are much more prolific of food than the same extent of the richest land. Once in the year an acre of good land carefully tilled produces a ton of corn, or two or three cwts. of meat or cheese. The same area at the bottom of the sea on the best fishing grounds yields a greater weight of food to the persevering fisherman every week in the year. Five vessels belonging to the same owner, in a single night's fishing, have brought in I 7 tons weight of fish, an amount of wholesome food equal in weight to that of 50 cattle, or 300 sheep. The ground which these vessels covered 
during the night's fishing could not have exceeded an area of 50 acres.

Large as is the present supply of fish, and considerable the refuse of our fisheries as manure, much greater things are yet to be accomplished in this way, in both our supply of food, and of fertilizers for our land. The increasing scarcity and high price of butcher's meat leaves no doubt that a great field is open for the application of increased capital and skill to our sea-fisheries. Though the supply of fish to Billingsgate is constantly increasing, it fails to. keep pace with the demand. The well-known fishing grounds of the North Sea are yet only partially fished. The Dogger Bank, which has an area of several hundred square miles, and is most prolific of fish, is to a great extent unworked by the trawlers, and new grounds are still being discovered where fish are found in great abundance. Between England and the continent the average depth of the German Ocean is 90 feet. One-fifth of it is occupied by banks, which are always being added to by the muddy deposits of the rivers of both countries. In extent they are equal to the superficial area of Ireland. To these banks the animals of the ocean chiefly resort, and this great and prolific field is free to the industry of all.

It was stated by a recent writer in Blackwood's Magazine that no department of British industry has received such a remarkable impulse from railways as the seafisheries of the United Kingdom. They have, in fact, completely revolutionized it. Before the Eastern Counties Railway was constructed, the transport of fish from Yarmouth to London was effected by light vans drawn by post-horses, and the quantity amounted to about 2000 tons a year. Nearly double that quantity is now conveyed to London and the great manufacturing towns in the course 
of a fortnight. During the year 1853 , the annus mirabilis of the Yarmouth fishery, 12,000 tons of fresh herrings alone were despatched from that place to London and the provinces. At Grimsby the quantity of fish landed in I 872 , and transmitted by rail, averaged 600 tons a week, or at the rate of more than 31,000 tons a year. The prodigious quantity of wholesome food now daily forwarded into the interior of the country from our principal fishing stations almost exceeds belief. The station-master of Lowestoft informed the Royal Commission of 1864 that in the two preceding years he had often despatched from that town roo truck-loads of fish a day, each truck containing from three to four tons. From 4000 to 5000 tons of herrings, and 1000 tons of other fish, have been sent by railway from the town of Dunbar alone in the course of a single week into the interior of Scotland. Before this rapid mode of transport was invented, the consumption of fresh fish was restricted to the seaboard, the metropolis, and a few of the most considerable provincial towns. To the mass of our island population the red herring was the only representative of sea-fish which ever met their eyes; now there is scarcely a hamlet in which the poor man's frugal dinner is not occasionally varied by a dish of fresh herrings or some other cheap fish, which the facilities of transit from the coast have brought to his door. The increase of fishing power brought of late years to bear upon the sea is equally remarkable. In 1814 only five vessels were fitted out as deep-sea trawlers from Yarmouth, and not one from any other port of the United Kingdom. There cannot now be less, on the most moderate estimate, than I000 sea-going trawlers, hailing from British ports and working in the North Sea, and certainly not less than 300 in the English Channel, and 100 in the Irish Sea. For 
many years there has been a gradual increase in the number of fishing smacks in every port of the United Kingdom.

Fish, crayfish, and many other marine products form an easily digestible and pleasant food, which, it is maintained, is also calculated to stimulate mental activity. Civilized nations cannot abstain from this important aliment without detriment to themselves. Fish, even without any elaborate dressing, form a good and easily prepared meal for the labouring classes. Their flesh contains as large an amount of protein as pork; Ioo lbs. of fish flesh contains as much nourishing matter as $200 \mathrm{lbs}$. of wheat bread or $700 \mathrm{lbs}$. of potatoes. It is an essential advantage of the fisheries that their products supply delicacies for the tables of the rich and wholesome cheap food for the poorer classes.

According to calculations made some years ago, the daily consumption of fish per head amounted to one-seventh of a pound in London, one-twentieth of a pound in Paris, and one-fortieth of a pound in Berlin.

The great importance of fish as an article of food may be clearly shown by a comparison of the total supply of fish to London in the course of a single year. At this time there are between 800 and 900 trawl vessels engaged in supplying the London market with fish; and assuming the annual take for each to average 90 tons, this would give, a total of some 80,000 tons of trawled fish. This quantity is irrespective of the vast quantities of herrings, sprats, shell-fish, and descriptions of fish which are supplied by other modes of fishing. On the east coast of England, and in the London fish-market, the trade divide the fish into two classes_-"prime" and "offal." The "prime" comprise sole, turbot, brill, and cod. The "offal" are chiefly haddock, plaice, and whiting. The term "offal" 
seems to have been introduced when the demand for fish and the means of conveying it to market were much more limited than at present, and when it was therefore often found necessary to throw overboard much of the less valuable descriptions, which could not bear the cost of transport. The use of the word "offal" may now be held to signify the more plentiful and lower-priced class of fish, which finds its way in the greatest abundance to the large towns. The proportion of "prime" and "offal" fish caught by the trawl varies considerably, but may be taken at an average of one-fourth " prime " to three-fourths of "offal." Of " prime," the sole seems to be the general favourite. It is more eaten in London than any other description of "prime" fish, and during the summer a considerable supply is sent daily from the London fish-market to Paris.

Notwithstanding the enormous increase which has taken place in the population of the metropolis during the last twenty years, it is very questionable if the weight of fish annually received has not actually diminished. The falling off in the supplies which reach us by water is very remarkable. In 1848 it amounted to 108,739 tons; but in $187 \mathrm{I}$ it fell to 44,077 tons. This reduction has been gradual but continuous from year to year. The quantity brought to town by railway has, on the other hand, increased, but hardly in the ratio of the diminution by water. There are no statistics of our fish supplies by rail available prior to 1865 , but the quantity which reached us in this way in I87I was 72,386 tons. The fish imports into London by water were in-

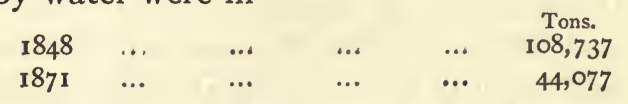

The total weight of fish brought to London by water and rail was in- 


$\begin{array}{llllll}1866 & \ldots & \ldots & \ldots & \ldots & \begin{array}{c}\text { Tons. } \\ 132,004\end{array} \\ 1867 & \ldots & \ldots & \ldots & \ldots & 122,523 \\ 1868 & \ldots & \ldots & \ldots & \ldots & 122,287 \\ 1869 & \ldots & \ldots & \ldots & \ldots & 113,782 \\ 1870 & \ldots & \ldots & \ldots & \ldots & 117,095 \\ 1871 & \ldots & \ldots & \ldots & \ldots & 116,463\end{array}$

Our imports of fish from abroad have largely increased, as will be seen by the following figures, giving the value:-

$\begin{array}{rrrrrr}1856 & . . & \ldots & \ldots & \ldots & £ 228,075 \\ 1866 & \ldots & \ldots & \ldots & \ldots & 631,552 \\ 1876 & \ldots & \ldots & \ldots & \ldots & 1,459,974\end{array}$

Of the imports in 1876,966 , I 19 cwt.-about one-thirdwas fresh fish not of British taking.

We also imported in 1876 train oil or blubber to the value of $£ 445,262$, spermaceti or head matter valued at $£ 290,359$, and seal-skins value $£ 219,540$, making a total of $£ 2,415,135$. This is exclusive of sardines, anchovies, caviare, oysters and shell-fish, pearls, mother-of-pearl, tortoise-shell, coral, sponges, and other articles obtained from the fisheries, which would swell up the aggregate to over . $£ 3,000,000$ of products obtained from the sea.

We exported in that year, of British produce :-

\begin{tabular}{|c|c|c|c|c|c|}
\hline Salmon to the & lue of & $\cdots$ & $\cdots$ & & $\measuredangle 39,083$ \\
\hline Cod and ling & ", & $\ldots$ & $\ldots$ & $\ldots$ & 44,383 \\
\hline Herrings & ," & ... & $\ldots$ & $\ldots$ & 732,737 \\
\hline Pilchards & ", & ... & $\ldots$ & $\ldots$ & 19,222 \\
\hline Unenumerated & ", & $\ldots$ & $\ldots$ & $\ldots$ & $67,33^{2}$ \\
\hline Oysters & ", & ... & $\ldots$ & $\ldots$ & 50,047 \\
\hline
\end{tabular}

In the last quarter of a century the Irish fisheries have declined by fully one-half in the number of boats and men employed. In I870 there were stated to be under 9,000 vessels and boats, and 38,000 men and boys. Owing to the numerous indentations, the coast line of Ireland is 
estimated at upwards of 2500 miles. The length along which the more important herring and mackerel fisheries are carried on does not, however, exceed 250 miles, and the value of the capture of these- $£ 330,000$-amounts to fully two-thirds of all the fish taken around the coast. When, therefore, it is considered that on the remaining 2250 miles of coast not more than $£$ I 50,000 of fish is taken, it will be understood why an equal amount of cured fish has to be imported from America and other foreign countries.

The latest official report on the Irish fisheries shows that, exclusive of the home consumption in 1876, fish were shipped to England to the value of $£ 504,7 \mathrm{I} 9$, thus divided :-

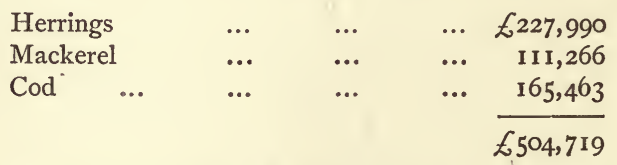

The number of craft of all kinds engaged off Ireland in fishing for sale, in 1876, was returned at 5965, with crews of 22,773 men and 920 boys. In Scotland, in the same year, the number of boats was 14,547 of 106,440 tons, with crews of 45,263 , and there were as many more other persons employed as curers, coopers, etc. The value of the boats was estimated at $£ 455,8 \mathrm{I}$ I, of the nets $£ 563,8 \mathrm{I}$, and of the lines $£ 108,347$, making a total of $£ \mathrm{I}, 127,994$.

We have official annual reports respecting the fisheries of Ireland and Scotland; but the collection of returns for England was discontinued with I850, at the same time that the branding and punching of the barrels of cod and ling ceased. We are not able, therefore, to form any very accurate estimate of the extent and progress of the coast fisheries for England and Wales.

The immense value of the fisheries of British North 
America will be seen by a glance at the following figures. About 1000 decked vessels and 17,000 open boats are engaged in fishing within the four provinces of Nova Scotia, New Brunswick, Quebec, and Ontario; for the other parts of the Canadian Dominion we have no authentic details. 42,000 men are actually engaged in fishing, while 200,000 persons are estimated to be supported almost entirely by this industry in its various branches. The annual produce of the fishery of these four provinces is about $£ 2,000,000$, and the boats, nets, and other instruments represent a capital of over $£ 600,000$. In Nova Scotia alone there are 9500 vessels and boats engaged in the fisheries, valued at $£ 210,000$, manned by 19,000 men, with nets, etc., to the value of $£$ I I 4,000 .

The fisheries are not only of importance to us in consequence of the vast amount of wealth that can be drawn from the deep, apparently without diminution, or exhausting its source, but because by this means a body of able and hardy seamen may be found to conduct the commerce of a maritime country during peace, and to become its gallant defenders on the ocean in time of war. This inexhaustible source of national wealth and greatness appertains in an especial manner to the British Possessions in the northern hemisphere, and has long excited the rivalry of the citizens of the New England States, who are aided by bounties granted by the general Government.

The Atlantic fishing ground situated in British waters reaches from the Bay of Fundy along the southern coast of Nova Scotia, around Cape Breton and Prince Edward Island, and embracing the Bay of Chaleur, extends to the Island of Anticosta and Newfoundland, the coast of Labrador, and the Magdalen Islands. There is probably no part of the world where such extensive and valuable 


\section{I4 The Commercial Products of the Sea.}

fisheries are to be found, as within the Gulf of St. Lawrence. Nature has bountifully provided within its waters the utmost abundance of those fish which are of the greatest importance to man, as affording not only nutritious and wholesome food, but also the means of profitable employment. These fisheries are prosecuted as well in the open waters of the gulf, as within every bay, harbour, creek, cove, and inlet in connection with it.

Quebec possesses, in the river and gulf of St. Lawrence, an extent of coast of 1000 miles, where the cod, herring, mackerel, salmon, and other fisheries are carried on successfully. In the men that sail the fishing fleets of British North America, we see the elements of a very powerful marine, which will be found invaluable in times of national danger.

The following figures show the value of the exports only, the produce of the fisheries of our North American colonies for the year I873:-

\begin{tabular}{|c|c|c|c|}
\hline anada & $\ldots$ & $\cdots$ & $\ldots £_{154,992}$ \\
\hline New Brunswick & $\ldots$ & $\ldots$ & 70,823 \\
\hline Nova Scotia & $\ldots$ & $\ldots$ & 717,301 \\
\hline Prince Edward Isla & land & .. & 200,100 \\
\hline British Columbia & $\ldots$ & $\ldots$ & 406,000 \\
\hline Newfoundland & & $\ldots$ & ... $1,631,086$ \\
\hline
\end{tabular}

In the previous year it was $£ \mathrm{I}, 000,000$ more, without British Columbia, of which the return was not given. This return merely assumes the market value of the products in the colonies; but in the foreign markets to which they are sent they will realize a fourth or a fifth more, and this, be it observed, is exclusive of the large local consumption of fish, oil, etc.

Boston is the fish-market of the United States; and 
the product of the New England fishery is estimated at $£ \mathrm{r}, 600,000$ yearly, of which Boston alone handles more than half.

At the Cape of Good Hope fish forms the principal article of the food of the population, and the poorer classes live almost entirely on it, its price being lower than in almost all other civilized countries.

It is difficult, nay, almost impossible to form an estimate of the probable consumption of fish within the colonial borders. Judging, however, from the great quantities used in a dried, pickled, and smoke-dried state, as an article of internal traffic, and taking into consideration that fish is almost the chief food of the lower orders in Cape Town and the other ports, the consumption must necessarily be very considerable.

The principal foreign market for the fish trade of South Africa is the Mauritius, the exports of dried fish to that colony being from 2000 to 2500 tons annually, of the value of $£ 30,000$. The average import of fish at the Mauritius in the three years ending I870 was about $44,000 \mathrm{cwt}$. There are also fisheries carried on from the island, for in I870 there were 329 fishery works, and at Rodriguez 44, employing 90 boats and 193 men.

At Ceylon the imports of fish are about 77,000 cwt. annually, and at Singapore about 40,000 cwt. of dried and salted fish are imported yearly.

On the coasts of some of the Indian presidencies there are extensive fisheries.

How many a locality in the Indian Ocean is there to which the lines of Milton are applicable !-where 
... part single, or with mate

Graze the seaweed, their pasture, and through groves

Of coral stray ; or sporting, with quiet glance

Show to the sun their wav'd coats draped with gold."

The Chinese are pre-eminently a fish-eating people, and the vast demand for fish there can only be supplied by artificial means. The shad is called by the Chinese "sam-li;" it is of superior flavour and great size, and is produced by artificial means and conveyed in "congs," large vessels made of coarse earthenware, to all parts of the empire.

It has been supposed that nearly a tenth of the population of China derive their means of support from the fisheries. Hundreds and thousands of boats crowd the whole coasts, sometimes acting in communities, sometimes independent and isolated. There is no species of craft by which a fish can be inveigled which is not practised with success in China. Every variety of net, from vast seines, embracing miles, to the smallest hand-filet, in the care of a child; fishing by night and fishing by day; fishing in moonlight, by torchlight, and in utter darkness; fishing in boats of all sizes; fishing by those who are stationary on the rock by the seaside, and by those who are absent for weeks on the wildest of seas; fishing by cormorants; fishing by divers; fishing with lines, with baskets-by every imaginable decoy and device. There is no river which is not staked to assist the fisherman in his craft. There is no lake, no pond, which is not crowded with fish; A piece of water is nearly as valuable as a field of fertile land. At daybreak every city is crowded with sellers of live fish, who carry their commodity in buckets of water, saving all they do not sell to be returned to the pond or kept for another day's service. 
In the port of Okhotz, Siberia, fish is almost the only food of the inhabitants, flour and groceries being unheardof luxuries, and meat very scarce. Even the cattle and poultry are fed on fish.

The general idea that the Southern Australian seas are inferior in piscatory resources to the colder waters of Europe seems to be wholly unfounded. At proper seasons of the year, and when reasonable precautions have been taken and the close months observed, the creeks and estuaries are leaping with fish.

In Victoria, not only around the great inland sea-lake of Port Phillip, for the sustenance of the crowded population of the capital, but in outlying ports and sequestered coves, families, singly and in clusters, draw their whole subsistence from the fisheries. The total number of fishing boats belonging to the Hobson's Bay district amounts to nearly 500, and all of them are busily employed.

Let us glance briefly at the statistics of the value of some of the principal fisheries. The Norwegian fisheries bring in to the hardy Northerners not less than $£ 3,200,000$ per annum, a magnificent sum for a country possessing a population of barely $2,000,000$ souls. In Russia the products of the fisheries are estimated at $£ 3,500,000$; in Denmark they bring in about $£ 160,000$; and the value of those of France reach about $£ 3,500,000$.

The take of the French fisheries for 1873 was thus officially returned :-

\begin{tabular}{|c|c|c|c|c|c|}
\hline \multicolumn{4}{|c|}{ Cod fishery, Iceland } & $\ldots$ & $\begin{array}{l}\text { Francs. } \\
6,719,774\end{array}$ \\
\hline & \multicolumn{3}{|c|}{ Newfoundland } & $\cdots$ & $9,981,547$ \\
\hline Herring fis & shery & $\ldots$ & $\ldots$ & $\ldots$ & $9,401,307$ \\
\hline Mackerel & , & $\ldots$ & $\ldots$ & $\ldots$ & $3,483,343$ \\
\hline Sardine & $"$ & $\cdots$ & $\ldots$ & $\ldots$ & r 3,757,534 \\
\hline \multirow[t]{2}{*}{ Anchovy } & ", & $\ldots$ & $\ldots$ & $\ldots$ & 469,695 \\
\hline & \multicolumn{3}{|c|}{ Carried forward } & .. & \\
\hline
\end{tabular}




\begin{tabular}{|c|c|c|c|c|}
\hline Bro & ight & ard & & $\begin{array}{c}\text { Francs. } \\
43,8 \mathrm{I} 3,200\end{array}$ \\
\hline Other species & . & $\ldots$ & $\ldots$ & $25,878,896$ \\
\hline Oysters ... & $\ldots$ & ... & $\ldots$ & $1,956,334$ \\
\hline Mussels... & $\ldots$ & $\ldots$ & $\ldots$ & 817,2 I I \\
\hline Other shell-fish & ... & $\ldots$ & $\ldots$ & 485,478 \\
\hline Crustaceans & $\ldots$ & $\ldots$ & $\ldots$ & $2,285,45^{8}$ \\
\hline Line fishery & $\cdots$ & $\cdots$ & $\ldots$ & $3,094,787$ \\
\hline & & & & 78,33 \\
\hline
\end{tabular}

Besides seaweed and sand as officially valued at $£ 60,000$. ing :-

The French fisheries gave employment to the follow-

\begin{tabular}{|c|c|c|c|}
\hline & & $\begin{array}{l}\text { Cod fishery of } \\
\text { Newfoundland } \\
\text { and Iceland. }\end{array}$ & Coast fishery \\
\hline Vessels and boats & $\ldots$ & 420 & $19,5^{85}$ \\
\hline Tonnage & $\ldots$ & 54,622 & 101,488 \\
\hline Men employed & $\ldots$ & I 1,965 & 65,5 or \\
\hline
\end{tabular}

Out of a gross return of $80,000,000$ francs the coast fisheries brought in over $63,000,000$ francs.

Both in the home and foreign fisheries many improvements have been carried out of late years in boats, nets, and appliances. In 1873 a great improvement was effected in France by the introduction of capstans worked by steam for hauling in the nets. Steam vessels are also now employed in fishing operations at Teste, Rochelle, and other ports.

The sale of fish in the Paris markets in 1854 was to the value of $7,500,000$ francs $(£ 300,000)$, of which about $\mathrm{I}, 000,000$ francs was for fresh-water fish. In $\mathrm{I} 860$ the sales reached about $10,000,000$ francs. Paris consumed the following quantities of fresh-water fish, etc. :-

$$
\begin{array}{llllrlrr}
\text { Eels } & \ldots & \ldots & \ldots & 230,440 & \ldots & \ldots & 328,000 \\
\text { Barbel } & \ldots & \ldots & \ldots & 23,870 & \ldots & \ldots & 23,826 \\
\text { Bream } & \ldots & \ldots & \ldots & 34,160 & \ldots & \ldots & 94,176 \\
\text { Pike } & \ldots & \ldots & \ldots & 325,840 & \ldots & \ldots & 354,232 \\
& & & \multicolumn{3}{c}{\text { Carried forward }} & \ldots & 800,234
\end{array}
$$




\begin{tabular}{|c|c|c|c|c|c|c|c|c|}
\hline & & & Bro & $\begin{array}{c}1854 \\
\text { lbs. } \\
\text { ught forw }\end{array}$ & & & $\ldots$ & $\begin{array}{c}1877 . \\
\text { lbs. } \\
800,234\end{array}$ \\
\hline Smelts & $\ldots$ & $\cdots$ & $\cdots$ & - & $\cdots$ & & $\ldots$ & 290,454 \\
\hline Gudgeon & $\ldots$ & $\ldots$ & $\ldots$ & 40,686 & $\ldots$ & & $\ldots$ & 39,060 \\
\hline Lampreys & $s \ldots$ & $\ldots$ & $\ldots$ & I, 756 & $\ldots$ & & $\ldots$ & 286 \\
\hline Perch & ... & $\cdots$ & $\ldots$ & I 7,870 & $\ldots$ & & $\ldots$ & 28,738 \\
\hline Tench & .. & $\ldots$ & $\ldots$ & 66,880 & $\ldots$ & & $\ldots$ & I 54,674 \\
\hline Trout & $\cdots$ & $\cdots$ & $\ldots$ & - & $\cdots$ & & ... & 5,128 \\
\hline Various si & mall & white fish & & 252,480 & $\ldots$ & & ... & I, I 57,434 \\
\hline Crabs & $\ldots$ & $\ldots$ & $\ldots$ & I 82,988 & $\ldots$ & & $\ldots$ & 328,008 \\
\hline Snails & $\ldots$ & $\ldots$ & $\ldots$ & - & $\ldots$ & 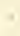 & $\ldots$ & I 90,284 \\
\hline Frogs & $\ldots$ & .. & $\cdots$ & - & $\ldots$ & & $\cdots$ & 22,562 \\
\hline
\end{tabular}

-valued at $I, 500,000$ francs.

There was also sold of sea-fish at the central markets, $3 \mathrm{I}, 489,202$ lbs., valued at I3,I9I,845 francs, together a total of over $£ 634,000$ sterling.

The consumption of other fish was stated in 1854 to have been of-

Preserved fish.

Sardines ...

Tunny ...

Anchovies ...

Salted fish.

Codfish in casks

, dried

Salted herrings

Smoked ,

Mackerel ...

Salmon ...

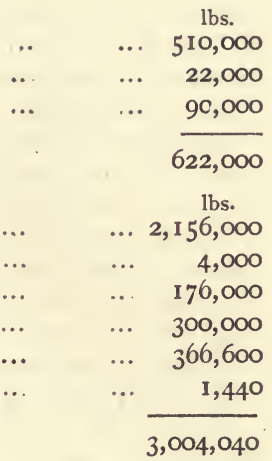

The sale of these has, however, more than doubled in the last quarter of a century.

It is not possible to form an accurate estimate of the extent or value of the fisheries and the products of the fisheries in various countries. But as regards our own 
special commerce, we have some few official figures to work upon. Taking the latest year for which full and complete returns are given, we find that the imports into the United Kingdom reach over $£ 6,000,000$ in value. Guano is included because it is a deposit of sea-birds, and may, therefore, be considered to some extent a product of the sea.

The exports of fish of British catch in 1874 were valued at $£ \mathrm{I}, 077,065$, and if we add the export of salt for the fisheries, fishing nets, hooks and lines, sails and cordage, and other supplies, we shall have fully a value of $£ \mathrm{I}, 500,000$.

The great city of Amsterdam and the present unsurpassed seaport of Liverpool arose from the industry and enterprise of a few fishermen, who found those spots convenient for their dwellings and pursuits-a fact of history thus poetically recorded :-

"Where Mersey's stream, long winding o'er the plain, Pours his full tribute to the circling main, A band of fishers chose their humble seat, Contented labour blest their fair retreat.

Inured to hardships, patient, bold, and rude, They braved the billows for precarious food; Their straggling .huts were ranged along the shore, Their nets and little boats their only store. But now perceive the alter'd prospect round, Where splendid tracts of opulence are found; Yet scarce two hundred annual rounds have run Since first the fabric of this power begun. His noble stream inglorious Mersey roll'd, Nor felt his waves by labouring art control'd ; Along his sides a few small cots were spread, His finny brood their humble tenants fed; At opening dawn, with fraudful nets supplied, The paddling skiff would brave the specious tide, Ply round the shores, nor tempt the dangerous main, But seek ere night the friendly port again." 
Value of the Imports of Products of the Fisheries into THE UNITED Kingdom IN 1870.

We give the statistics of this year, as it is the latest for which details have been furnished by the Board of Trade. None of the minor articles are now enumerated in the official trade returns :-

Fish

\section{Isinglass}

Mother-of-pearl shells ...

Oil, cod-liver...

, whale ...

Whale fins

Orchella weed

Pearls

Seal-skins
$£ 768,387$

83,023

76,489

$\begin{array}{lr}\ldots & 64,157 \\ \cdots & 890,553\end{array}$

... 79,482

… 112,693

$\begin{array}{rr}\ldots & 112,693 \\ \ldots & 16,675\end{array}$

... 270,024

Carried forward

$\ldots \longdiv { £ 2 , 3 6 1 , 4 8 3 }$

If we could trace the wealth of nations arising from their fisheries, it would be found to be beyond calculation.

The following gives the foreign trade in fish of different countries :-

\begin{tabular}{|c|c|c|c|c|c|}
\hline \multicolumn{3}{|c|}{ Russia : Imports, I874-Herrings } & ... & barrels & 430,430 \\
\hline \multirow{3}{*}{\multicolumn{2}{|c|}{$\begin{array}{l}\text { Exports-Caviare } \\
\text { Norway : Exports, 1874- } \\
\text { Anchovies }\end{array}$}} & .. & $\cdots$ & ... lbs. & 106,989 \\
\hline & & & & & \\
\hline & & $\ldots$ & $\cdots$ & dunkers & 102,933 \\
\hline Dried fish & $\ldots$ & ... & $\ldots$ & ... cwt. & 383,830 \\
\hline Fresh fish & $\ldots$ & value & in specie & lar, 4s. $6 d$. & 50,836 \\
\hline Spring herrings & ... & $\ldots$ & tonder & 3 bushels & 17,784 \\
\hline Other herrings & $\ldots$ & $\ldots$ & ," & ," & 919,539 \\
\hline Klipfish (dried co & & $\ldots$ & $\ldots$ & ... cwt. & 599,576 \\
\hline lted fish & $\ldots$ & $\ldots$ & $\ldots$ & tonders & 69,424 \\
\hline Lob & $\ldots$ & $\ldots$ & $\ldots$ & thousands & 74 \\
\hline Seal-skins & $\ldots$ & $\ldots$ & $\ldots$ & ... No. & 95,356 \\
\hline Train oil & $\ldots$ & $\ldots$ & $\ldots$ & tonders & 103,365 \\
\hline weden : Import & $374-$ & & & & \\
\hline Herrings & $\ldots$ & $\ldots$ & $\ldots$ & cubic feet & $, 163,560$ \\
\hline
\end{tabular}


22 The Commercial Products of the Sea.

Spain : Imports, $1875-$

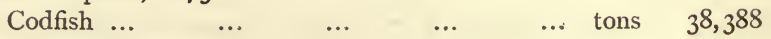

Italy : Imports, $1875-$

Fish of all sorts $\ldots \quad \ldots \quad \ldots \quad \ldots$ tons $4 \mathrm{I}, 9 \mathrm{I} 8$

United States : Exports, 1875-

Fish, dry, pickled, etc. $\quad \ldots \quad \ldots \quad \ldots$ value $£ 601,750$

France : Produce of the Fisheries in $1876 \ldots \quad \ldots$ value $£ 3,560,000$

Algeria : Exports, $1876-\quad \ldots \quad \ldots \quad \ldots$ value $£ 240,000$ 


\section{PART I.}

FOOD PRODUCTS OBTAINED FROM THE SEA. 



\section{CHAPTER I.}

\section{THE COD FISHERY IN VARIOUS COUNTRIES.}

The cod fishery of Scotland-The Grand Bank fishery, NewfoundlandBultow fishing described-Preparing the fish-The Norway fishery-Lofoden fishery-Iceland-Consumption in the French colonies-Fishery at St. Pierre and Miquelon.

ONE of the most important of the sea-fisheries, whether regard be had to the size of the fish or the number taken, is that for the cod. This fishery is carried on not only around the shores of the British Islands, but is prosecuted on a very extensive scale on the shores of Newfoundland and other coasts of the Atlantic, in Norway, Iceland, and other quarters.

The cod (Gadus morrhua) abounds between $40^{\circ}$ and $60^{\circ} \mathrm{N}$. lat. It is essentially a sea-fish, and is never met with in fresh waters, preferring the depths of the sea, which it only quits to spawn on the coasts or the banks.

The following return for the last ten years shows the average take of codfish in Scotland, at least as far as regards the quantity cured :-

$\begin{array}{rlllllr}1867 & \ldots & \ldots & \begin{array}{c}\text { Dried. } \\ \text { cwt. } \\ \text { 1 } 19,638 \frac{1}{4}\end{array} & \ldots & \ldots & \begin{array}{r}\text { Pickled. } \\ \text { barrels. }\end{array} \\ 1868 & \ldots & \ldots & \text { 1 } 13,831 & \ldots & . & 9,659 \\ 1869 & \ldots & \ldots & 135,585 \frac{1}{4} & \ldots & \ldots & \text { 10,319 } \\ 1870 & \ldots & \ldots & 145,288 \frac{3}{4} & \ldots & \ldots & 9,945 \\ 1871 & \ldots & \ldots & 119,030 & \ldots & \ldots & 9,283\end{array}$


26 The Commercial Products of the Sea.

\begin{tabular}{|c|c|c|c|c|c|c|}
\hline 1872 & $\ldots$ & $\ldots$ & $\begin{array}{c}\text { Dried. } \\
\text { cwt. } \\
\mathbf{1} 45,976 \frac{1}{2}\end{array}$ & $\ldots$ & $\ldots$ & $\begin{array}{l}\text { Pickled. } \\
\text { barrels. } \\
\text { I I ,940 } \frac{1}{2}\end{array}$ \\
\hline 1873 & $\ldots$ & $\ldots$ & $160,716 \frac{1}{2}$ & $\ldots$ & $\therefore$ & $12,3^{8} 1 \frac{1}{2}$ \\
\hline 1874 & $\ldots$ & $\ldots$ & I $43,466 \frac{1}{4}$ & $\ldots$ & $\ldots$ & 6,754 \\
\hline 1875 & ... & $\ldots$ & $x 87,788 \frac{1}{2}$ & ... & ... & $8,503^{\frac{1}{2}}$ \\
\hline 1876 & $\ldots$ & $\ldots$ & I I I , 457 & $\ldots$ & $\ldots$ & 6,109 \\
\hline
\end{tabular}

The number of cod, ling, and hake taken in Scotland in I 876 was 3,454, I98. 59,816 cwt. of dried fish were exported, being rather more than half the cure; but this was $22,000 \mathrm{cwt}$. below the export of the previous year.

The cod fishery on the Irish coast commences in the lough opposite Moville, about the Ist of October, and ends about the Ist of July. They move out, and as the weather settles in spring, the fishermen follow them eight miles or more, and finally twenty miles out to Hamden Bank.

Newfoundland may be said to have a monopoly of the cod fishery, and the market is every day increasing. All tropical people like codfish, and must have it, and therefore, if the colonists could obtain 5,000,000 tons, they could not supply the demand in future ages.

The roe of a cod contains 2,000,000 eggs, and if all these came to maturity, one cod would fill the ocean in a few years; but though countless millions perish, if we do not violate the law of nature by destroying the mother or breeding fish, we cannot lessen the quantity.

The Grand Bank appears to be the great breeding ground of the species, and the finest fish is caught there. The quantity of codfish annually taken from the banks and shores of Newfoundland, and the coasts of Labrador, on the average of years, may be stated to be as follows :-

Cwt.

$\begin{array}{ccccc}\text { By the Americans } & \ldots & \ldots & \ldots & \mathbf{1}, 500,000 \\ \text {, French } & \ldots & \ldots & \ldots & \mathbf{1}, 000,000 \\ \text { By" British subjects } & \ldots & \ldots & \ldots & \mathbf{1}, 500,000\end{array}$

-worth about $15 s$. or $16 s$. a cwt.

$4,000,000$ 
Taking the annual catch on the banks and along the shores at 2,750,000 cwt., and averaging 50 codfish to the cwt., it is estimated that there are drawn from the waters around Newfoundland $137,500,000$ codfish in a year. Besides the fish, the oil obtained from the cod forms also a considerable item in the business. About one hogshead of oil is produced from every five tons of fish.

The bultow is a long line, with hooks fastened along its whole length, at regular distances, by shorter and smaller cords, called "snoods," which are six feet long, and are placed on the long line $\mathrm{I} 2$ feet apart, to prevent the hooks becoming entangled. Near the hooks, these shorter lines, or snoods, are formed of separate threads, loosely fastened together, to guard against the teeth of the fish. Buoys, buoy-ropes, and anchors or grapnels are fixed to each. end of the line; and the lines are always laid, or as it is termed "shot," across the tide, for if the tide runs upon the end of the line the hooks, will become entangled, and the fishing will be wholly lost. For the deep-sea fishery the bultow is of great length.

The French fishing vessels, after anchoring on the bank, in about 45 fathoms of water, run out about IOO fathoms of cable, and prepare to catch cod with two lines, each 3000 fathoms in length. The snoods are arranged as previously described, and the hooks being baited, the lines are neatly coiled in half-bushel baskets, clear for running out. The baskets are placed in two strong-built lugsail boats, and at three o'clock in the afternoon both make sail together, at right angles from the vessel on opposite sides. When the lines are run out straight, they are sunk to within two feet of the bottom. At daybreak next morning, the boats proceed to trip the sinkers at the extremities of the lines, and while the crew of each boat are 
hauling in line and unhooking fish, the men on board heave in the other end of the lines with a winch. In this way 400 of the larger bank cod are commonly taken in a night. The fish are cleaned and salted on board, and stowed in the hold in bulk; the livers to be boiled for oil are put in large casks, secured on deck.

The French vessels engaged in this fishery are from I 50 to 300 tons burthen; they arrive on the Grand Bank early in June, and on the average complete their cargoes in three months.

The bultow mode of fishing is wholly used by the French on the banks, and the large vessels have over five or six miles of lines and 6500 hooks lying at the bottom at a time. The shore fishery is prosecuted by hook and line, either in whale-boats or flats.

The bultow is considered very injurious, in destroying what the fishermen call the mother fish, that is, the female fish near the time of depositing their spawn, when they are very torpid and careless in seeking food, which at this period they do always on the bottom, when the bultow hooks are laying ready baited to entrap them. It is but seldom that these fish are caught in the common way, with hook and line, and it is a wise provision of Providence that the cod is so prolific, otherwise the bultow system would almost destroy the species. Leuwenhock counted 9,384,000 eggs of spawn in a cod of middling size, and Hanmer $3,686,750$ in one that weighed 12,540 grains.

The moment a fish is taken off the hook it should be bled. This may be done by the person who is employed in taking it off the hook. The fish must then be headed, split up, and gutted,-in doing which, the sound should be carefully preserved for cure. The fish should then have the bone removed, care being taken that it shall be cut away 
to within 20 or 22 joints of the tail, not directly across but by the splitter pointing the knife towards the tail, and cutting the bone through the two joints at once, in a sloping direction, so as to leave the appearance of the figure 8. This looks best, and it has this advantage, that the fish are not mangled, as they are apt to be when the bone is cut square through one joint. A slight incision should also be made along all the adhering part of the bone, to allow any remaining blood to escape, and the splitter should then drop his fish into clean water. The fish should be then thoroughly washed in the sea from all impurities ; but where this cannot be so immediately accomplished, they should be dropped instantly into a large tub or vat full of sea water, where they should be carefully washed, and the water should be poured out of it when it gets foul, and fresh water supplied. Care must be taken to remove the black skin that adheres to the laps of the fish.

If these operations cannot all be performed on board the fishing craft immediately after capture, the fish, upon being taken off the hook and immediately bled, which is absolutely essential, should be put into boxes, or some convenience, to keep them from exposure to the air, and from being trampled on, which would be extremely hurtful to them. But it may be again repeated, that the more of the above operations that can be performed immediately after capture, the better. If the salting can be done on board the craft, it will be of the greatest advantage, as the sooner the fish are in salt after they are taken out of their native element, the greater is the chance that their cure will be successful. But, whether cured at sea or on shore, they ought in no case to be permitted to remain a longer period before being laid in salt than 48 hours.

When cured on shore, the cod is flung from the fisher- 
man's boat upon the rough stage, where it is received by the "cut-throat," who, with a sharp knife, lays open the fish across the throat and down the belly, and passes it to the header. This operator proceeds to extract the liver, which is dropped into a vessel by his side, to be converted into cod-liver oil. He then extracts the entrails and wrenches off the head, and throws these into another receptacle, to be preserved for the farmer, to mix with bog and earth, thus forming a most fertilizing compost for his fields. The tongues, however, are taken out, and also the sounds, and these, fresh or pickled, are an excellent article of food. The fish is then passed to the splitter, who, by a dexterous movement, cuts out the backbone nearly to the tail, and thus lays the fish entirely open, and capable of being laid flat on its back. This is the nicest part of the operation, and the splitter always commands higher wages than the rest of the operators. The salter next takes the fish and washes it well from all particles of blood, salts it, and places it in piles to drain. After laying the proper length of time it is washed, and spread to dry on the "flake," which is formed of spruce boughs, supported by a framework resting on upright poles. Here the cod are spread out individually to bleach by exposure to sun and air, and during this process require constant attention. At night, or on the approach of rain, they are made up into little round heaps, with the skin outward, in which state they look very much like small haycocks. When the "bloom," or whitish appearance, which for a time they assume, comes out on the dried fish, the process is finished, and then they are quite ready for storing. On being conveyed to the premises of the exporting merchant, they are first "culled," or assorted, into four different kinds, known as "Merchantable," "Madeira," "West India," and "Dun," or broken fish. The first is the best quality, the 
second a grade lower, the third is intended for the stomachs of negroes, and the fourth, which is incapable of keeping, is used at home.

Dun fish are prepared in the following manner:-.. They are caught early in spring, and often in February. The cod are taken in deep water, split, and slack salted; then laid on a pile for two or three months in a dark store, covered for the greatest part of the time with salt hay, or grass, and pressed with some weight. In April or May they are opened and piled again as close as possible in the same dark store till July or August, when they are fit for use.

The cod sent to hot countries are packed by screw power into small casks called "drums;" those which go to the Mediterranean are usually exported in bulk. Large quantities of dried codfish are shipped to Brazil, and there is hardly an inhabited corner of that vast empire where the Newfoundland cod is not to be found, being carried on the backs of mules from the seacoast into the most distant provinces of the interior. The negroes of the West Indies welcome it as a grateful addition to their vegetable diet. To all parts of the Mediterranean it finds its way; Italians, Greeks, and Sicilians equally relishing the produce of the sea harvest. The Spaniards and Portuguese are our best customers, and all over the sunny peninsula the "bucalo" is a standing dish. In the warmer regions of the earth the people seem to have a special liking for the dried and salted cod, and to them it is an almost indispensable article of food.

The air bladder, or as it is called, cod's sound, which consists almost entirely of pure gelatine, sells at a high rate in any market into which it has been introduced. Cod's tongues and sounds form, even at present, a considerable 


\section{The Commercial Products of the Sea.}

export from the ports of the States and the British-American colonies on the Atlantic.

Norway possesses a long and much-indented coast, which furnishes a large part of the fish consumed in England. The most valuable Norwegian fisheries are in the extreme north, near the Lofoden Islands, and within the Arctic circle. The great fisheries, and those of most interest to all Englishmen, are the deep-sea fisheries for cod and herrings, which constitute the most important branch of industry practised in Norway. The annual produce of these amounts to a million of money, and they give employment to from 20,000 to 30,000 men, and from 5000 to 6000 vessels. The cod are caught in two ways, with nets, in the English fashion, and with lines. The lines, or rather cables, are 1000 fathoms long, and are supported in each case by a buoy, and secured by anchors to prevent their drifting. Each line is furnished with 1200 hooks, at distances of five feet from each other, each hook being on a separate hookline of about a fathom in length. The lines are set at night and taken up in the morning. The fish are not salted, but are merely gutted and hung up in pairs upon poles, to be dried in the wind, and when thus cured they are exported in large quantities, under the name of round or stock-fish. The great cod fishery ends in April.

The number of cod caught in 1869 amounted to $20,700,000$, of which about $12,000,000$ were salted and prepared as klipfish (baccalau), and about 7,800,000 were hung up to dry as round-fish (stock-fish); the remainder, about 900,000, were cured for home consumption.

The produce of the fishery in 1870 consisted of $16,456,000$ fish, equal to about 8800 tons when dried. Besides this, there were secured 21,500 barrels of cod oil, and 5000 barrels of cod roe. 
The fishermen pay great attention to the curing. The fish is neatly packed in boxes with the fins trimmed off.

The extensive fishing bank which is periodically visited by the cod, stretches from Rost, a low group of islands forming the south-westernmost range of the Lofoden chain of islands, up to the very head of the West Fiord; a distance of about 70 English miles.

The number of boats engaged is nearly 6000 , of which one-fifth have nets, and the remainder lines and deep-sea lines. The latter are of various lengths, supported on the surface by floats, with a buoy at each end. From this floating line, numerous baited lines are suspended at regular distances. There are also about 400 vessels of various kinds usually assembled, partly for fishing, but chiefly for purchasing fish as they are brought in.

The boats engaged in fishing with nets are from 36 to 40 feet long, and nine to ten feet wide, with a depth of not more than three feet. They are provided with only a single mast, about 24 feet high, carrying one large square sail. But each boat has as well Io or 12 oars, by means of which her sturdy crew can propel her against an adverse wind. For fishing with lines, smaller ships, mostly boats, are used. The crew usually consist of five men and a boy.

In the month of December, the first shoals of cod usually begin to appear on the western banks of the islands, arriving from the open sea. These are soon followed by great masses of fish. But as these western outside shores are shallow, the ports few, and the whole coast exposed to the frequent fury of the North Sea, not more than from 600 to 800 boats venture on the hazards of this early fishing, and the take seldom exceeds $5,000,000$ or $6,000,000$ of fish. 


\section{4 \\ The Commercial Products of the Sea.}

In the mean time the inhabitants of the inner or eastern side, protected from northerly winds, and favoured with many bays of refuge, examine their shores day by day with baited hooks, to discover if the precursors of the dense shoals of cod have yet appeared in the West Fiord, and great is the public exultation when the joyful news of their arrival is announced. This important event takes place generally in the latter end of December, but not before the middle of January do the fish arrive in great masses.

Codfish are taken by the Lofoden fishermen by three methods:-(I) with hand lines; (2) with set lines; and (3) with nets.

Hand lines requiring little capital and producing small results, are only employed by the poorest fishermen. These are satisfied with 50 fish to each man per day, although occasionally they will capture double that number. They bait with herrings, salt or fresh, and when these are all. gone, with the roe of the fish they have caught. Sometimes, when the shoals of cod are very thick and dense, the men adopt another method also, with a single line requiring no bait. Providing themselves with a long cord, armed with a large and sharp hook at its extremity, they sink it into the swarming masses below, having first attached to it, a couple of feet above the hook, small fishes of tin, for the purpose of attracting the cod by their glitter. The fishermen then jerk the hook sharply upwards, occasionally securing a curious fish, though cruelly wounding many others that are not taken.

Set-line fishing requires larger apparatus: a boat, a crew, and from 500 to 3000 hooks baited at once. The hooks are attached to fine snoods of hemp or cotton, which in their turn are'suspended on long lines; each boat puts out at least 24 of these lines, every line carrying more than 


\section{The Cod Fishery in Various Countries. 35}

Ioo hooks. Set-line fishing usually begins in the afternoon, but in any case only at the time and in the place prescribed by the officers appointed at each station for the purpose. The baited hooks are generally suspended near the bottom, but if there is reason to believe that the fish have risen, as they sometimes will, the lines are shortened and the bait raised to the required height by means of glass floats. They are then left all night. On the following morning the lines are taken in, and the crews are well content with an average take of 50 to 60 fish daily on each set of $\mathrm{I} 20$ hooks.

Net fishing requires larger capital, and is only followed by the more wealthy fishermen, who provide both nets and lines, to be used according to circumstances.

When the fish are fat, and especially during the spawning season, they will hardly take any notice of the bait; then is the time the nets are used. Every boat carries at least 60 nets of from ro to 20 fathoms deep. These nets are suspended in the water from floats of wood, cork, or glass. Hollow glass floats are preferred, and are almost exclusively used at Lofoden. Sixteen to 20 nets bound together in one length are set out in the afternoon, and, weather permitting, are taken up the following morning. A catch of from 500 to $600 \mathrm{cod}$ is considered satisfactory; but if this number is largely exceeded, part are left in the nets till the afternoon, because the boats could not safely carry so heavy a freight, together with the crew and wet nets. The total take of cod by these various methods has ranged during the last few years from I $5,000,000$ to $25,000,000$ of fish per annum.

Although the cod fisheries of Lofoden are the largest and most renowned, Norway has many others of great value along her far-stretching sea-board. 
36 The Commercial Products of the Sea.

The produce of the Lofoden fisheries in I87I was of klipfish 750,000 vogs, and of round-fish 340,000 vogsthe vog being about $44 \mathrm{lbs}$. This was equal to nearly 24,000 tons of codfish. The above take of fish yielded 31,000 barrels of oil, and 25,000 barrels of roes. On an average about 400 cod yield a barrel of liver, varying in price from $£ \mathrm{I}$ to $£ \mathrm{I} 6 s$. $8 d$.

It appears that there is a great abundance of fish, especially cod, off the coast of Iceland, and that this fish is a set-off for the scanty agriculture of the island. The cod remain during winter near the coast, and the fishing commences during the spring; in summer, the fish are further out in deep water. Owing to the smallness of the population, the same persons attend to agriculture and to fishing. Taking the whole coast collectively, the winter and spring fishings give large fat cod, which are sold at the trading ports, and afterwards prepared for export; whereas the summer fishings usually yield small cod, haddock, cole-fish, and halibut, which are sorted and smoked for home consumption.

The Icelanders chiefly fish from open boats-seldom from decked ones. Their boats so vary in size as to range from two to I 2 oars, with as many men as oars, and one to act as steersman. The boats have all projecting prows, are very easily rowed, and light in construction. As a rule they carry only one lugsail. The larger boats - from six to I2 oars - are employed in the deeper fishings, often far out at sea. The fishing is effected by means of small drift-nets, deep-sea lines, hand lines, or long lines, according to the depth of water and the kind of fish. Fishing with the drift-net generally ceases about the middle of April, and is succeeded by the deep-sea or hand lines. The hooks used are generally the same as the French, but 
some of the fishermen use the old Iceland hook, which is nearly 20 inches long. Fishing with the ordinary lines is carried on when the other two methods are no longer prcductive, and takes place all round the island. From one to four lengths of strong, thick line, each length measuring 60 fathoms, are spliced together, and vertical or hanging lines six feet in length are spliced into this at a distance of six or eight feet apart; a hook baited with snails or mussels is fastened to the end of each hanging line. The hooks used are the ordinary tinned English No. 5. A boat carries from 20 to 40 such lines, which are sunk to the bottom by means of stone weights; their position is indicated by buoy-ropes kept up by small floating barrels marked with the owner's name. The lines are placed across the entrance of bays and rivers, or sometimes at the outside of them, and are taken up twice or thrice a day, according as the weather permits. As many as 80 of these long-line boats may sometimes be seen collected together, busy fishing from three to four miles off the coast.

Line fishing is conducted in Iceland on a much more limited scale than at Newfoundland, in relation both to the size of the boats and the length of the lines. This arises, not from the scarcity of the fish, but from the poverty of the people, which prevents them from obtaining the requisites necessary for larger operations. The fish are packed for export sale in many ways. In order to obtain what are called white fish, the fish are opened, gutted, cleansed, and partially boned, then washed in sea water and placed in salt. After three or four days' salting they are washed in sea water and laid out on the rock to dry; they are then ready to be packed in warehouses for shipment on suitable opportunity. This is, of course, dried 


\section{The Commercial Products of the Sea.}

salt cod. Another fish for home consumption is the heinge fish, in which the cod are split up along the back and hung up unsalted to dry in sheds with open latticed sides. This second kind is more shrivelled up in appearance than the first, and is eaten uncooked by the Icelanders, who likewise dry and eat the refuse heads.

Somehow or other we have let the French forestall us in that quarter. The French fishermen catch more in the Iceland seas than the Icelanders themselves, and carry away to France as much cod as is worth $6,725,000$ francs a year $(£ 270,000)$. The abundance of fish in the Iceland seas attracted fishermen from many other countries; but, for some reason not easily to be explained, the French are now the only foreigners who carry on the fishing largely. Some few Belgians are occasionally seen, and a few Scotch fishermen from the Shetlands, but their number is insignificant. The Danish Government, to which Iceland belongs, lays down certain limits within which foreign fishing-boats may not approach the shore; but collisions unfortunately occur between those who carry on the line fishing, because the French, when driven by the weather or by the movements of the shoal, come within the prohibited limits, then entanglements of gear result, followed by quarrels. The French fishermen usually have a fleet of 250 vessels there in the season, averaging 90 tons, and worked by 4400 men. These vessels are mostly schooner-rigged. Although the native boats are nearly ten times as numerous, and the crews twice as many, the French catch more cod than the Icelanders, for the majority of the native craft are, as we have said, mere small open boats. The quantity caught altogether must be very large, for the Icelanders alone export 5,000,000 lbs. to 7,000,000 lbs. annually. The average number of French vessels employed in the cod 
fishery in Newfoundland and Iceland in the three years ending with 1860 was 500 , of about 65,000 tons, and em. ploying 14,000 to I 5,000 men.

The produce imported into France in 1860 , which was a fair average of the five years previous, was as follows :-

\begin{tabular}{|c|c|c|c|}
\hline Wet $\operatorname{cod} \ldots$ & .. & $\cdots$ & $\begin{array}{r} \\
\text { Kilogrammes. } \\
\ldots \quad 19,780,556\end{array}$ \\
\hline Dry cod ... & $\ldots$ & $\ldots$ & .. $7,370,659$ \\
\hline Cod oil ... & $\ldots$ & $\ldots$ & $2,050,846$ \\
\hline ," not purifiec & & $\ldots$ & 284,649 \\
\hline Cod roes & ... & ... & 72,489 \\
\hline Other produce-so & ound & & 870,655 \\
\hline
\end{tabular}

The codfish re-exported to the various French colonies, to Italy, and the Barbary States, varies from $3,000,000$ to 9,000,000 kilogrammes.

The average catch of cod in the French colonies of St. Pierre and Miquelon, according to the official returns, was for the five years ending I87I :-

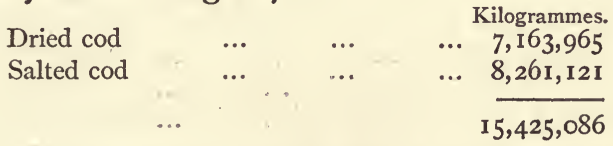

There were employed in the fishery, directly or indirectly, I94 vessels, of 30,56I tons, employing 3439 men. The number of boats was 673 , and the number of fishermen 5773 .

The number of French vessels employed in 1873 in the cod fisheries was-in Newfoundland 190, of 23,035 tons, and in Iceland 230 of 19,585 tons.

The average annual produce of the French cod fishery in the five years ending I 874 was :-

$\begin{array}{ccccc}\text { Dry codfish } & \ldots & \ldots & \ldots & 6,419,538 \\ \text { Green codfish } & \ldots & \ldots & \ldots & \text { I0,985, I27 } \\ \text { Cod oil ... } & \ldots & \ldots & \ldots & 449, \text { IO2 } \\ \text {, sounds } & \ldots & \ldots & \ldots & 4 \text { I } 7,223 \\ \text { ", roes ... } & \ldots & \ldots & \ldots & \text { II } 3,415\end{array}$


The kilogramme is equal to $2 \frac{1}{5} \mathrm{lbs}$.

The number of ships employed at St. Pierre and Miquelon in the cod fishery is 76 , and of boats 590 ; the aggregate tonnage, 12,386. The number of fishermen employed in them is 5335. These figures are the average of the five years ending 1874 .

The imports of cod into the French colonies in 1874 were as follows :-

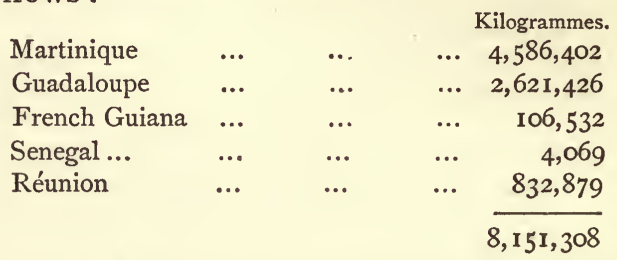

This shows a declining consumption, judging by the average imports for the undermentioned years in the five coînies :-

$$
\begin{aligned}
& \begin{array}{rrrrrr} 
& & & & \text { Kilogrammes. } \\
\mathbf{1} 829-\mathbf{I} 83 \mathbf{I} & \ldots & \ldots & \ldots & 9, \mathbf{1} 20, \mathbf{1} 57
\end{array} \\
& \begin{array}{lllll}
1832-1836 & \ldots & \ldots & \ldots & 9,613,200
\end{array} \\
& \begin{array}{lllll}
1837-1851 & \ldots & \ldots & \ldots & \mathbf{1} 8,031,078
\end{array} \\
& \begin{array}{lllll}
1852-1873 & \ldots & \ldots & \ldots & 9,352,736
\end{array}
\end{aligned}
$$

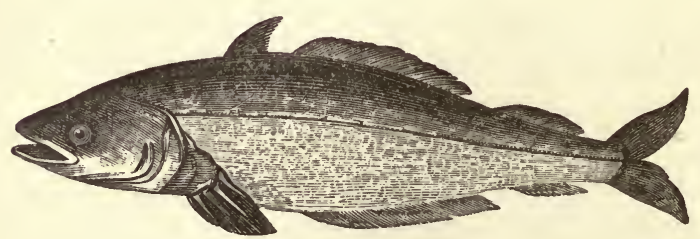

Coal-fish. 


\section{$(4 \mathrm{I})$}

\section{CHAPTER II.}

\section{THE HERRING FISHERY.}

The British herring fishery-The Scotch fishery and take of fish-Mode of curing-Statistics of export-Definition of official brands-Statistics of the Norfolk fishery-Description of drift and other nets-Kippered herrings-The Dutch fishery-The French fishery-The Norway fisheryThe North American fishery.

OF almost equal importance to that of the cod is the herring fishery, which supports and gives employment to many thousand of persons. Herrings (Clupea harengus), when in prime condition, form a cheap, delicate, and nutritious article of food, and when promptly and efficiently cured, become valuable as provision. But their value in this respect must necessarily depend entirely on the quality of the fish when caught, and on the degree of promptitude and care which may be exercised in curing them.

The common herring, which is so abundant in all markets, is taken generally on the coast of Europe, from the extremity of Scandinavia as far as Normandy, and sometimes even lower down, but never so low as the Bay of Biscay. Swedes, Norwegians, Russians, Danes, Germans, Dutch, English, Scotch, Irish, and French, all take part in the herring fishery. The number of men employed in Great Britain is about 100,000, and that of vessels 3000- 


\section{The Commercial Products of the Sea.}

not counting the number of small boats. Herrings breed with remarkable rapidity. The females are in number upwards of two-thirds more than the males, and some of them contain as many as 60,000 eggs. The abundance of herrings is such that it is not diminished either by the fishing or by the destruction committed by large fish and by innumerable birds. The herrings move in shoals, which are sometimes from eight to ten miles long by two to four wide, and of unknown depth. These immense masses, which advance very rapidly, are distinguished by the presence of birds flying above them, and by the agitation of the sea, and at night the place which they occupy is phosphorescent. In I 78I herrings came in such large quantities to Buscoé, on the coast of Gottenburg, that they were caught by the hand. In $1784 £ 56,000$ worth of herrings were caught in the space of a fortnight in Loch Urn. In 1773 there was such an invasion of herrings in Loch Torridon, that I 50 fishing-boats caught from 12 to 20 casks each in the space of a single night. In some cases 50,000 herrings have been caught by a single cast of the nets, and it is also said that the fishermen of Dunkirk, Calais, Dieppe, and Boulogne have frequently taken 280,000 herrings in a night. Not very long ago the fishermen of one English town, Lowestoft, caught in two days 22,000,000 herrings! And this at only one of a hundred such places. At the retail price of a penny each, this two days' catch would come to $£ 91,666$; but it was so beyond all the mercantile force or curing-power of the place, that tons had to be sold for manure.

But few people know the great value of our legitimate fishing ground at home. At the same season when the pilchards arrive from the south, and swarm on the coast of Cornwall, herrings in myriads arrive from the north and 


\section{The Herring Fishery.}

fill the bays and friths on the north-east coast of Scotland. During the herring season there are upwards of 15,000 fishing-boats, manned by about 62,000 men, employed on the coast of Scotland every year, and who land their fish, when they are successfully cured, barrelled, and the bulk of them is sent away to foreign countries. These delicious fish, although caught, cured, and sold by Presbyterian fishermen, neither pious Neapolitan, Portuguese, nor even the good Pope himself, ever hesitates to enjoy the relish of a heretical pilchard or herring.

The Herring Fishery of Scotland.-Mr. Bremner, in his work on "The Industries of Scotland," gives an interesting description of the outfit and results :-

"During the fishing season Wick presents one of the most interesting scenes to be witnessed in the whole range of industry. In the course of the afternoon the crews of the boats moored in the harbours or anchored in the bay prepare to start for the night's fishing. The nets are got on board, the masts are hoisted, the sails set, and soon the bay becomes shrouded in dark-brown canvas. With a breeze from the south-east, the departure of the boats is a splendid sight, for then they have to tack out; and the spectators are favoured by beholding a regatta on a grander scale than any to be witnessed elsewhere. The movement seaward is simultaneous along the coast, and by the time the last of the fleet gets outside the heads of Wick Bay, a dark line of boats extends continuously from Duncansby Head to the head of Clyth, a stretch of a dozen miles. Generally those in the boats have no fixed intention as to what spot they shall select for casting out their nets, and taking their draw from Neptune's lottery. If a good haul was previously got at a certain part, those who get it endeavour to return to that part; but in most cases the 


\section{The Commercial Products of the Sea.}

boats which were successful on the previous night are watched and followed, notwithstanding the fact that it is an exceedingly rare thing for a boat to have two exceptionally successful nights following each other.

"Having chosen their water, the crew of each boat begin to 'shoot' their nets, which, while being 'laid' in their boats, were united in a continuous train or drift, by knotting together the 'back-ropes.' Each boat has a train of nets about half a mile in length and ro yards in depth. By corks attached at the top and weights at the bottom, the nets are made to float perpendicularly in the water. This wall of netting is suspended from buoys which allow it to sink 20 or 30 feet below the surface. The nets are put into the sea immediately after sunset, and most of the crew then endeavour to snatch ' 40 winks' of sleep. In the course of an hour or two some of the nets are hauled up and examined to see whether the fish have been 'striking.' If there should be good signs of fish in the locality, the nets are allowed to lie for some time. The herrings are caught by getting fixed in the meshes while trying to pass through. The captain decides the proper time for taking in the nets, and when he gives the word, all hands fall to work. As the nets are got on board, the fish are shaken out of them and fall into the hold, where, after a gasp or two, they expire. If the night's labour has yielded 20 or 30 barrels of fish, the men think themselves fortunate; but it is no unusual thing for a boat to bring ashore 80 and even 100 'crans,' or barrels.

"The return of the boats in the morning is an event of much more importance and interest to people on shore, and from an early hour anxious inquiries are made respecting the fortunes of the night, while those who have leisure go to make observations from the piers and cliffs. As the 


\section{The Herring Fishery.}

boats crowd into the harbours, an opportunity is afforded for judging of the uncertainty of the fishermen's fortunes. A score or two of boats sail swiftly in, with barely as many fish on board as will suffice for the breakfasts of the crews ; then, at a toilsome pace, come one or two boats filled to the thwarts with herrings. In one case, the night's labour of six men, and the use and risk of property worth from $£ \mathrm{IOO}$ to $£ 200$, has produced a return of about $6 d$.; in another, of $£ 60$ or $£ 80$. The average catch at Wick in I 868 was $4 \mathrm{I} \frac{3}{4}$ crans, drawn from returns of individual boats which ranged from one to upwards of 200 crans, or barrels.

"When all the boats are in, the harbours are quite crowded; but, by mutual arrangement, the boats having large quantities of fish to land are allowed to get near the quays. The fish are shovelled into wicker baskets, and then carried to the 'station,' where they are measured and emptied into the 'boxes,' or enclosures of wood from 20 to 30 feet square, the sides of which are about 30 inches in height. As soon as a convenient quantity of fish has been deposited in the box, a troop of women, arrayed in canvas and oil-cloth, approach, and the 'gutting' and 'packing' processes begin. The gutters, each armed with a small knife, surround the box, and, taking a herring up in the left hand, operate upon it with the knife held in the right hand. The rapidity of their movements is surprising, a good worker being able to dispose of 1000 fish in an hour. As the fish are gutted, they are dropped into baskets and handed over to the 'packers,' who 'rouse' them with salt in a large tub, and then arrange them in layers in the barrels. A free use of salt is made, the herrings being first coated with it separately in the rousing process, and the layers in the barrels afterwards thickly overlaid with it. The barrels are temporarily covered and allowed to stand for Io days, 


\section{The Commercial Products of the Sea.}

during which time the fish settle down considerably. Additional fish are then put in, until the barrels are quite full. After being examined and approved by an officer of the Fishery Board, the barrels receive the official brand, which is accepted in the market as a guarantee that the fish are of a certain standard of quality. A large number of coopers and labourers are engaged in preparing and heading up the barrels, and removing them from one place to another."

At almost all the stations in Scotland the disposition of the fishermen for some years past has been to substitute first-class boats for the second class, and even to employ first-class boats at the line or white fishery, where boats of the second class were formerly used.

An enterprising curer at Wick has lately made trial of sending carrier pigeons to sea with boats which fish at a large offing. The pigeons were the means of supplying intelligence of the results of the night's fishing before the boats arrived, so that preparations could be made accordingly, and they also conveyed instruction when a steam-tug or other assistance was required. Another experiment made with success at Wick was the employment of a traction engine to haul up the boats for the winter, instead of gangs of men, and the work was found to be done cheaper.

The take of herrings in the Scotch fisheries has been on the whole large in the past ten years :-

\begin{tabular}{|c|c|c|c|c|c|c|}
\hline & & & $\begin{array}{l}\text { Total cured. } \\
\text { Barrels. }\end{array}$ & & & $\begin{array}{c}\text { Exported. } \\
\text { Barrels. }\end{array}$ \\
\hline 1867 & $\ldots$ & $\ldots$ & $825,5^{89}$ & $\ldots$ & $\ldots$ & $478,704 \frac{1}{4}$ \\
\hline 1868 & ... & ... & $651,433^{\frac{3}{4}}$ & ... & ... & $368,744^{\frac{3}{4}}$ \\
\hline I 869 & ... & $\ldots$ & 675,143 & ... & $\ldots$ & $381,333^{\frac{3}{4}}$ \\
\hline I87o & & $\ldots$ & $833,160 \frac{1}{2}$ & ... & $\ldots$ & $530,55^{8}$ \\
\hline 1871 & $\cdots$ & $\ldots$ & $825,475^{\frac{3}{4}}$ & ... & .. & $55^{1}, 605^{\frac{1}{4}}$ \\
\hline 1872 & $\ldots$ & ... & $773,859 \frac{1}{2}$ & .. & ... & 549,631 \\
\hline
\end{tabular}




$\begin{array}{ccccccc} & & & \begin{array}{c}\text { Total cured. } \\ \text { Barrels. }\end{array} & & & \begin{array}{c}\text { Exported. } \\ \text { Barrels. }\end{array} \\ 1873 & \ldots & \ldots & 939,233^{\frac{1}{2}} & \ldots & \ldots & 668,008 \\ 1874 & \ldots & \ldots & 1,000,561 & \ldots & \ldots & 737,314 \frac{3}{4} \\ 1875 & \ldots & \ldots & 942,980 & \ldots & \ldots & 660,970 \frac{1}{2} \\ 1876 & \ldots & \ldots & 598,197 \frac{1}{2} & \ldots & \ldots & 400,423^{\frac{1}{2}}\end{array}$

About one half of the total number cured are "officially branded" by the inspectors.

The respective brands are "crown full," "maties," "spent," and "mixed." Maties are those fish in which the roes and milts are perfectly but not largely developed-and it is well to understand that this is the state of the fish in which it is truly in the best condition for food-and when it will be found most delicious to eat, as well as most nutritive. Although it does not exhibit, whilst in this condition, so bulky an appearance as it does when it is in that of a full fish, it is in reality much fatter, for the bulk of the full fish is deceptively produced by the great enlargement of the roe or milt, and this does not take place without a corresponding diminution of the body of the fish. The full fish, however, are those which are most sought after in a mercantile point of view, because of their larger appearance. The spent or shotten fish having just performed their function of spawn ing, and having been thereby reduced to a miserable, lean, and poor state, are unpalatable, and more or less unwholesome as food when in a fresh state, and in a still greater degree when cured. The more immediately they are taken after spawning the worse they will be, and the longer the time that expires after their performance of that function, the less unpalatable or unwholesome they will become. But it is always advisable to avoid taking or using them in any way until they shall have had time to be fully recruited after their thorough exhaustion from spawning.

The Norfolk Herring Fishery.-From a recent official 


\section{The Commercial Products of the Sea.}

report by Mr. Frank Buckland, fishery inspector, we are able to glean some valuable statistics. Yarmouth for 800 years past has been celebrated for its herring fishery. The total value of luggers, trawling smacks, and other vessels, with the various buildings on shore belonging to the herring and trawling fisheries, is supposed to be little short of $£ 750,000$ sterling at the present time.

The fishing vessels belonging to Yarmouth and Gorleston are :-

First class, over 15 tons, luggers and smacks $\quad \ldots \quad \ldots \quad \ldots \quad 512$

Second class, over 2 tons and under 15 tons $\quad \ldots \quad$.. 459

Total .. $\overline{97 \mathrm{I}}$

The crews of these vessels would average eight hands. There are also 37 small boats, with an average of two men, and about 120 Scotch and West country vessels, which land their fish in Yarmouth harbour during the herring season.

Of late years the number of boats and men has greatly increased, and the depth and length of the nets have also been augmented. Fourteen years ago there used to be about 15 yards on a rope; now an ordinary net is from 18 to 20 yards on the rope. Then the boats used to fish from 6I to 9I nets each; now they fish from IOI to I6I nets.

Many boats now fish with nets a mile and a third long; some boats have been known to use nearly two miles of nets. During the months of September, October, and November, it would be well within the mark to state that there are fishing for herrings every favourable night in the North Sea between 5000 or 6000 miles of netting. Formerly the herring nets were made of twine; of recent years they are nearly all made of cotton. Cotton is much softer, and fishes better than twine. 


\section{The Herring Fishery.}

The size of the drift-net varies on different parts of the coast. The herring-net used in the long-standing Yarmouth fishery may, however, be taken as an illustration of this particular kind of net, and the manner in which it is there worked agrees essentially with its operation in all the drift fisheries.

The drift-net, taking it altogether, consists of a number of nets, usually from I 20 to I3O, each of which is I 7 yards long, and between seven and eight yards deep. They are attached along their upper margin by short pieces of line a few inches apart to the back-rope, a double rope enclosing at short intervals single pieces of cork to keep that part of the net uppermost. These nets are fastened together at their extremities, and thus united form what is called a "train, fleet, or drift of nets," extending to a length of nearly a mile and a quarter. The depth to which the nets are sunk is regulated by ropes seven or eight yards long, called "seizings," two of which, from each net, are made fast to a stout warp running the whole length of the train, the warp itself being supported near the surface by small kegs or buoys, technically called "bowls." The warp is also useful in taking the strain off the nets, and in preventing their loss in case the train should be fouled and cut by a vessel passing over them when they are near the surface. The minimum size of the herring-mesh is fixed by law at "one inch from knot to knot along the line," or, to put it in a form perhaps less likely to be misunderstood, at one inch square. In practice, however, it is found that in order to catch good-sized fish rather larger dimensions are desirable, and meshes running from 31 to 34 instead of 36 to the yard are, with few exceptions, in use all around the coast.

Drift fishing is carried on at night. The nets are shot 


\section{The Commercial Products of the Sea.}

a little before sunset, the fishing-boat being kept before the wind, and with only enough sail set to take her clear of the nets as fast as they are thrown over. When all the nets are out, about 15 fathoms more of warp are paid out, and by this the vessel is swung round and then rides head to wind, a small mizen being set to keep her in that position.

The whole train of nets is now extended in nearly a straight line, the back-rope, to which the corks are fastened, being uppermost, and the body of the net hanging perpendicularly in the water, forming a wall of netting more than 2000 yards long, and about eight yards deep. The strain from the vessel serves to keep the net extended, and the whole-vessel and nets together-drifts along with the tide. The influence of the tide, however, is not equally felt throughout the whole extent of the nets. The train is consequently soon thrown into irregular curves, often leading to considerable confusion when many boats are fishing in close company.

During the day the herrings keep very much at the bottom, or in a considerable depth of water; but as night closes in, and if the weather be favourable, they become more active, swim nearer the surface, and in their attempts to pass through the barriers of netting on every side of them many become meshed, the gills of any moderatesized fish preventing its return when once the head has passed completely through the mesh.

If, after two or three hours, an examination of the first of the nets should show that many fish have been caught, the train is hauled on board and the fish shaken out. The nets are hauled in by means of a capstan and the warp to which the nets are fastened.

Drift fishing is carried on with craft of various sizes, 


\section{The Herring Fishery.}

from the Yarmouth decked lugger of 60 tons to the frail canvas canoe or curragh of the West of Ireland, the number of men and the quantity of net varying with the size of the boats.

The weight of fish carried from the Great Eastern railway stations in 1874 was as follows :-

\begin{tabular}{lllllr} 
Yarmouth & $\ldots$ & $\ldots$ & $\ldots$ & $\ldots$ & $\begin{array}{r}\text { Tons. } \\
27,517 \\
\text { Lowestoft }\end{array}$ \\
Harwich & $\ldots$ & $\ldots$ & $\ldots$ & $\ldots$ & $23,86 \mathrm{I}$ \\
& & $\ldots$ & $\ldots$ & $\ldots$ & 2,509 \\
\hline
\end{tabular}

In addition to the above, about 20,000 tons of trawl fish are sent to Billingsgate every year by carrying cutters and steamers from the Yarmouth fleets of trawling vessels in the North Sea. This would give 47,864 tons from Yarmouth alone, and including Lowestoft and Harwich, 74,234 tons of fish. To this must be added a very large quantity sent by steamers to London, Newcastle, Hull, etc., and many ship-loads exported to ports in the Mediterranean.

A very important trade, that of kippering herrings, has, during the last few years, been introduced into Yarmouth, mainly through the energy and enterprise of Mr. John Woodger. Herrings for kippering must be of the very best quality, and no salt is used in this process. The entrails of the fish are taken out; they are then carefully washed, and hung up in the smoking-house for a few hours. Large numbers of women are employed by the kipper merchants, and it is supposed that more than rooo lasts of herrings are now yearly required for this trade alone.

The quantity of herrings landed at the fish wharf, Yarmouth, between August and December, is about I 8,000 lasts. It is estimated that a last of freshly caught herrings weighs about two tons. Probably over 1000 lasts in each 


\section{The Commercial Products of the Sea.}

year may be added to this for herrings landed at Gorleston and other parts of Yarmouth harbour.

In 1873 there were landed at Yarmouth and Lowestoft, including the spring and autumnal fishing, 32,000 lasts of herrings. There are in each last 13,200 individual fish. The total number, therefore, caught in 1873 amounted to $422,400,000$, or nearly four hundred and twenty-three millions of herrings. Take these fish at a halfpenny each when cured and sold in the retail market, and we shall find the value of the herrings caught in one year by fishing vessels sailing out of Yarmouth and Lowestoft to be over $£ 875$,000.

Mr. J. G. Nall, in I866, estimated the entire capital embarked in the Yarmouth fisheries, including trawling vessels, to be about $£ 600,000$; this has since much increased. The value of the capital embarked in the Lowestoft fisheries is also very large.

The herring fisheries in Yarmouth and Lowestoft may therefore be truly said to be of national importance; the herrings alone caught would give about 14 meals in the year to every man, woman, and child in the United Kingdom, allowing one fish to a meal.

It appears that there are no herrings caught in January. Towards the end of February the fishermen begin to catch spring herrings, and the fishery lasts during March, April, and May. In June and July the midsummer herring fishery is carried on, more or less. In August little is done in herrings; the "harvest of the sea" begins in September and lasts until about Christmas. This is called the "autumn or home fishing."

The spring herrings are described as being nothing but skin and bone; there is no fat whatever about them. They are not good; indeed, hardly fit for human food. The mid- 
summer herring is a larger, handsomer, and fatter fish than the spring herring; for whilst the spring herrings are only from six to seven inches in length, the midsummer herring is generally eight to nine inches. As the warm weather comes on, so the quality of the midsummer herring improves.

The spring herring fishery begins at the end of February, and continues to the end of May. These herrings are of great value to the Lowestoft people; from $£ 20,000$ to $£ 30,000$ are put into circulation in Lowestoft, and upwards of 1000 men and boys employed on the water during the spring herring fishery. At that time boatowners have no other employment for their men; 80 to 90 boats go out from Lowestoft, and several from Gorleston, to catch these spring herrings.

A large proportion of these herrings is sold for bait to the Dutch and French fishermen, who come over to Lowestoft on purpose to buy them. They are used to bait the long lines, to catch halibut, turbot, etc.

\section{Herrings caught at Lowestoft.}

$\begin{array}{ccccccc}\text { Year. } & & \begin{array}{c}\text { Spring } \\ \text { herrings. } \\ \text { Lasts. }\end{array} & & \begin{array}{c}\text { Midsummer } \\ \text { herrings. } \\ \text { Lasts. }\end{array} & & \begin{array}{c}\text { Autumnal } \\ \text { herrings. } \\ \text { Lasts. }\end{array} \\ \mathbf{1} 873 & \ldots & \text { I } 887 & \ldots & 54 & \ldots & \text { I0, } 973 \\ \mathbf{1} 874 & \ldots & 2546 & \ldots & 112 & \ldots & 9, \mathbf{1 7 3} \\ \mathbf{1} 875 & \ldots & 1064 & \ldots & \text { 106 } & \ldots & -\end{array}$

The commercial importance of the Lowestoft fisheries may be seen from the following figures, showing the number of boats and men employed at the port :-

$\begin{array}{llllr}\text { Trawling smacks } & \ldots & \ldots & \ldots & 78 \\ \text { Luggers and dandies } & \ldots & \ldots & \ldots & 260 \\ \text { Small boats } \quad \ldots & \ldots & \ldots & \ldots & 120\end{array}$

The trawlers average 8 men and boys; total, 624. The 


\section{The Commercial Products of the Sea.}

luggers and dandies, Io men and boys ; total, 2600. Small boats, 2 men ; total, 240. This gives a total of 458 vessels of all classes, and 3464 men and boys.

This is the total of registered vessels and their crews, but it does not include the shore men, who are employed in the markets as packers, curers, etc. Nor does it include the West country or Scotch boats which use the port during the herring season. These may be safely reckoned as I 20 vessels, with 1000 men and boys.

On the Cornish coast 200 boats from Newlyn and Mousehole are engaged in the herring fishery, and employ at least 1000 persons. Each boat of modern build costs about $£ 250$, and carries nets which cost on the average from $£_{4}$ to $£ 4$ Ios. per net.

The quantity of herrings caught off Ireland in 1876 was I 80,3 18 mease, ${ }^{*}$ which was about 2000 meases below the take of the previous year. At the average of $25 \mathrm{~s} .5 \mathrm{~d}$. per mease, this gives a total value of $£ 226,803$.

The Dutch Herring Fishery.-Before the sixteenth century, when nearly all the countries of Europe were debarred the use of animal food during Lent, the consumption of herrings all over the continent was immense, and brought prodigious wealth to Holland. De Witt, the great Dutch statesman, mentions that about 2000 busses were employed by the Dutch in the herring fishery at home. Each buss had a complement of about 25 men, thus rearing about 50,000 seamen, besides giving bread and employment to several hundred thousand people on shore, in building busses and making nets, casks, etc. ; and it was an old proverb in Holland, "that the foundation of Amsterdam was laid on herring-bones." The Dutch fishery, besides employing so many thousand men in catch-

* A fish-measure of 500 herrings, sometimes spelt " mace" or " maize." 
ing and curing the herrings, employed many thousand more seamen for managing the merchant vessels which carried the produce of the fisheries to the various ports of the Baltic and Mediterranean seas. Thus, by cultivating and encouraging the herring fishery, the Dutch formed themselves into a great maritime power, and in the days of Oliver Cromwell possessed a navy not inferior to that of England.

In the fifteenth century the Dutch had 700 large vessels employed in the fishery, and the quantity of fish they caught was estimated at $30,000,000$ a year; in the seventeenth century the quantity rose to $50,000,000$; but it has since greatly declined. The English fishermen take at present about $7,000,000$ tons annually, and the Dutch not more than 35,000. In the year 1650 the Dutch had 5000 "busses," or large decked fishing luggers, on the east coast of Scotland; they were manned by 50,000 fishermen, and from this source the Dutch navy, so long the most formidable on the North Sea, was chiefly manned. The northeast coast of Scotland was chiefly the locality of the Dutch fisheries, and here they had to compete with the Norse fishers, who had possession of the Orkney and Shetland Islands and a great part of the Caithness coast, the creeks and harbours in which were used for the coast fisheries, while the larger vessels kept the sea.

The Dutch herrings, though caught almost on the same ground as the English or Scotch, fetch a higher price than any other in the world, and are eaten raw as a relish in Holland and Germany. The first barrel of new herrings that is taken is forwarded to the king at the Hague. It is carried in procession with banners and military music ; the day is one of public rejoicing, and a few of the new herrings are sent as presents to the nobles of the land. The Dutch 
bleed each herring, use the best quality of salt, and take the greatest care in the manipulation.

The herring is a very fat, oily fish, and unless carefully and rapidly cured with salt, becomes soon rancid and unfit for use. The herrings formerly cured in Scotland were not gutted and bled with a knife like the Dutch herrings, but were cured intact as they came out of the sea. No time was limited for putting the fish into salt; everything was done there as here, in the most slovenly manner; and while the Dutch herring found a ready market all over the continent, the Scotch found none, and the consumption was almost entirely confined to the home market.

The great advantage of the fishery inspectors now is, that they perambulate the curers' yards while the operation of curing is going on. They see that the women gut, salt, and pack the herrings properly, and within the time prescribed by the statute. They also take care that every cask shall contain at least 32 gallons, and that the full fish be separated from the lank or spawned fish. It requires 12 days to cure the herrings properly; at the expiration of that time the casks are opened again, when the fish are found swimming in the pickle, which is formed by the salt and the blood of the fish. The superfluous pickle is then drawn off, and the casks are filled quite full with herrings. The effect of the salt upon the herrings is to compress them into much smaller bulk, so that a cask which has been packed quite full of fresh fish, the day they were landed, at the end of 12 days is only about two-thirds full; or, in other words, Ioo barrels of fresh salted fish will only yield 70 barrels of well-packed cured fish.

The French Herring Fishery.-The herring fishery known in France in the eleventh century was long ex- 


\section{The Herring Fishery.}

clusively pursued by Dieppe and Rouen fishermen, who caught this fish in the North Sea, and distributed it over France and the Levant. Later, other maritime ports entered upon this industry; and in I 789 Fécamp had 50 boats occupied in the herring fishery. Now, after a decline of the fishery occasioned by the wars of the Republic and the Empire, it has taken a fresh start, and become of great importance to Dieppe and Boulogne. The herring fishery is carried on in France on the coasts of Dunkirk and Havre, from September to February or March, and is sometimes continued till May.

In France I 80 vessels, of 8000 tons burden, are employed in catching herrings for salting, and take about $8,500,000$ kilogrammes a year. Of these vessels about 100 belong to the port of Boulogne-sur-Mer; the rest to Dieppe, Fécamp, St. Valery-en-Caux, Calais, Treport, and Gravelines. The number of vessels employed in fishing herrings which are sold fresh is 470 , of about I0,000 tons burden, and they catch on an average I3,000,000 kilogrammes annually. They belong to the aforesaid ports, and also to those of Barfleur, Berck, Dunkirk, Etape, Le Hourdel, Port-enBessin, and St. Valery-sur-Somme. At Boulogne the fishery is better organized than anywhere else in France, and is carried on by means of associations composed of the owners of the boats and the crews.

A recent very productive year, in which but Iog boats and I 506 men were engaged from Boulogne, resulted in a catch of $45 \mathrm{I} 8$ lasts of fresh and salted herrings, the total money proceeds of which were $£$ I I 8 , OI 5 . In I 873,282 boats were employed, of 8350 tons, and employing 3750 men. The catch of herrings yielded over $£ 200,000$, and the value of the other fisheries carried on from the port $£$ II 5,000 more. The take of herrings on the French coasts in 1873 


\section{8}

The Commercial Products of the Sea.

amounted in value to somewhat under $£ 400,000$. The herring fishery of France realized in I866 a little over $7,000,000$ francs; in 1873 it reached nearly 9,500,000 francs.

The Norway Herring Fishery.-The herring is found from Mandal, on the extreme south of Norway, to the North Cape. They seem to live in the deep submarine valley between the $47^{\text {th }}$ and 67 th degrees of latitude; that is, from about the English Channel on the south, to the North Cape at the extreme north of Norway. It approaches the shore when about to spawn. They abandon water which has not at least the temperature of $4^{\circ} \mathrm{C}$. or $40^{\circ} \cdot \mathrm{F}$., either because this temperature is disagreeable to them, or they do not find suitable food. From some unknown cause, the localities where they present themselves vary each year. The fishermen begin to take a few spring herrings towards the end of March, which are very thin, but improve in July and August. The winter herrings are fished between I 5 th January and I 5 th March. About I,000,000 barrels are annually procured, of which a considerable portion finds its way to Great Britain, and the rest go to Sweden and the Baltic ports.

The North American Fishery.-The common American herring (Clupea elongata, Storer) is amongst the most valuable of food fishes. The habits, haunts, and seasons of the herring are matters of curious inquiry. It seems, however, now to be well established that the only migration of the herring is from the deep seas to the shores at the spawning season, and from the shore to the deep seas when this is over.

As early as March herrings are taken in nets on the coast, but the fish are so straggling and the seas so boisterous, that, except for bait, fishing does not commence 
till May. In this month a run of large fat herrings is taken in nets upon the banks, which lie 10 or 15 miles seaward, and carry about 75 fathoms water. A net 30 fathoms long and three deep is passed from the stern of a boat at anchor. The free end drifts with the tide, held to the surface by cork floats-sometimes the tides carry the net down 15 fathoms in a slanting direction-thus drifting from night to morning; the net is overhauled, and from 20 to 100 dozen is the ordinary catch. It is very evident that, owing to the distance from shore, and the need of calm weather for the boats and nets, as well as for the fish, which are very susceptible to rough seas, this fishing must be precarious. The boats are stout, weatherly keel boats, with a half deck, from five to 5 tons, carrying a jib, fore and main sail, and usually called second-class fishermen when entered at a regatta.

The "in shore run," a fish of smaller size, are taken in nets set to a buoy, instead of a boat, the free end drifting to the tide. These nets are often moored from one buoy to another to preserve a permanent position across a creek or small bay. In these various ways herrings are taken by the shore population of the whole Atlantic and Gulf coast of Nova Scotia, from the Bay of Fundy to Cumberland. The immense tides of the Bay of Fundy, leaving long flats and sand-bars at low tide, and the steep trap formation of its southern coast line have singularly altered the character of the fishery. Here the drift-net fishing is carried on, boats and nets drifting for miles upon the flow and returning upon the ebb, the nets twisted and coiled into apparently impossible masses. The shores of the trap formation being flat tables of trap reaching plane after plane into the sea; with no crevice to hold a stake or anchor a buoy, the fishermen procure stout spruce fir trees, and lopping off the 
branches, leave the long lateral roots attached to them. These they place upright in rows upon the bare rock, and pile heavy stones upon the roots as ballast, stretching their nets between them. Entirely submerged at flood tide, at ebb they are left high and dry, and often loaded down with fish caught by the gills in the meshes of the net. These nets are usually set for a large, lean spring herring, running for the flats in early spring to spawn. This method of fishing obtains throughout the whole trap district of the province bordering upon the Bay of Fundy.

The value of the herrings caught in the Dominion of Canada in 1876 was returned at $£ 825,620$.

Herring (Clupea harengus) and shad (Alosa sapidissima) are so abundant in North Carolina that the former sell for $6 s$. per 1000 , and the finest shad at from $6 d$. to Is. each. The seines used are of immense size, and are worked by steam power. A seine worked at the mouth of the Chowan is a mile and a half in length, and in it 300,000 herrings have been taken in one day. They also take from 1000 to 2000 shad at a catch. Steamers are at the wharves, constantly loading with these fine fish, packed in ice, for the New York and other northern markets. 


\section{$(6 \mathrm{I})$}

\section{CHAPTER III.}

THE PILCHARD FISHERY.

The pilchard fishery of Cornwall and Devonshire-Description of drift and seine nets-Process of cleaning and salting the fish-Statistics of catch in various years-Definitions of fish measures-Cornish sardines-Irish fishery-French fishery.

THE pilchard (Clupea pilchardus) is of a somewhat less compressed and rounded form than the herring. The great seat of this British fishery is the coast of Devonshire and Cornwall, particularly Mount's Bay, St. Ives, and Mevagissey, where they are caught in vast numbers. In July the early pilchard fishing commences, and from that time to the beginning of September the whole coast from St. Ives to the Ram Head is in a state of excitement and activity. So much do the comforts of all the labouring classes depend on a successful take of pilchards, that an unproductive season is nearly as disastrous as a deficient harvest on land would be.

The fish are taken in either drift-nets or seines. The former are for entangling the fish in the open sea, and are about half a mile in length, by five fathoms in depth. The latter are cast near the shore, and in shallow water. To work a seine three boats are required. The first large 
one, carrying the stop seine, is manned by a crew of nine, six rowing, two to shoot the seine, and one acting as bowman, on whom the course of the boat depends. The second boat is called the volgar or follower, and carries the tuck or smaller lifting seine. The third is the lurker, the smallest of the three, and is chiefly: occupied by the hirer or guide, and some boys. The seine is of various lengths, ranging from 250 to 300 fathoms, by I 3 to 16 fathoms deep. Its meshes are smaller than those of the drift-net, the object being to enclose the fish without meshing them.

The seine net has a line of head-ropes, to which are attached corks and other buoys, to keep its upper edge near the surface. To the lower edge are attached innumerable small pieces of lead, which bear it down and keep it close to the ground, the object being to shoot the seine in shallow water with a clear bottom. The "tuck" is a similar net, but of smaller dimensions; its mesh is of the same size as that of the seine, but it has in the middle a hollow bag, as it were, into which the fish go when the process of tucking is going on. These nets are very expensive, costing from $£ 300$ to $£ 600$.

The "drift" fishing employs about 47 boats. Each boat costs about $£ 200$, or when a set of three nets is provided, so as to fish for herrings and mackerel as well as pilchards, the cost is $£ 400$. Unlike the seine boats, the drift boats must all be manned by sailors.

As many as 4200 hogsheads, or over I 200 tons, of fish have been taken in one cast of the seine, but this enormous catch was an extraordinary haul. A good cast, enclosing a large shoal, has, however, often yielded 1200 hogsheads of fish.

The pilchards, when taken on shore, are gutted and 


\section{The Pilchard Fishery.}

cleaned by women and children, and piled, with layers of salt, in large heaps in cellars or warehouses, where they remain for about a month; and being subsequently washed and thoroughly cleaned, are packed in hogsheads and subjected to pressure to extract the oil, about three gallons being yielded by each cask, when the fish are fat.

Great quantities of salted pilchards are sent to the Mediterranean, particularly to Naples and other parts of Italy, where they are largely consumed during Lent.

The number of hogsheads exported in I85 I was 26,743 . The average for Io years then stood at 23,446 hogsheads. Taking the number at 2500 fish to the hogshead, over $58,500,000$ fish are caught annually, weighing 10,620 tons. About 5000 tons of salt are required to cure the catch for export, as there is but a small local consumption.

In the seven years ending 1863 the average annual export was only I 3,757 hogsheads, but I 859 and I 860 were unprecedently bad years, the take being only 3500 hogsheads. The catch of 1863 , on the contrary, was large, reaching 26,057 hogsheads. The shipments were larger at the close of the last century than they are now.

The total takes in Cornwall for the last three years have been very small, namely, $7543 \frac{1}{2}$ hogsheads in 1874 , $7337 \frac{1}{2}$ in 1875 , and 6700 in 1876 . In the last-named year only from 300 to 400 hogsheads were captured during the summer fishing, which ends on the I 5 th of September. These produced from $63 s$. to $67 s$. per hogshead. The main take was in the autumn and winter, and they went as high in price as Ioos. per hogshead.

Italy will absorb, at fair prices, as much as 30,000 hogsheads annually, and depends upon Cornwall for the supply.

Pilchards arrive on the coasts of Devon and Cornwall 
from June to September; sometimes they are caught about Christmas. A hogshead of pilchards, well cured and pressed, will hold 2500 to 3000 fish. The fresh fish weigh about $6 \frac{1}{2} \mathrm{cwt}$., and the salt $3 \frac{1}{2} \mathrm{cwt}$., but the weight of the hogsheads when cured and pressed is reduced to about $4 \frac{1}{2}$ cwt., including the weight usually allowed for the cask, $28 \mathrm{lbs}$. Ten thousand pilchards make a last. A hogshead is supposed to consist of eight baskets of fish, and a basket contains about 400 ; but this number varies with the size of the fish. The fish are sold by the long hundred $-\mathrm{I} 2 \mathrm{O}$.

A new industry has been started in Cornwall within a year or two, that of preserving small pilchards in oil in tins, after the manner of sardines. The seat of the company's operations is at Newlyn; a Frenchman conducts the operations. The Cornish sardines grow in favour and demand in London. Their flavour is considered quite equal to that of the foreign fish, and their nutritive qualities greater; while the extra size of the box, and the liberal way in which it is filled, all tend to commend the home product.

Large shoals of pilchards appeared off the coast of Cork and Kerry during the year 1876, principally from July to the end of October, some as late as November. They were in the greatest abundance off the Cork coast, and in many places came close in to the shore, and were captured by small seines drawn in upon the rocks. No efforts have yet been made in Ireland to cure for the continental markets, but some have been cured for home consumption on various parts of the coast. By degrees this fish is being regarded with more favour by the country people, and if they continue to frequent the Irish coasts as they have now done for some years, there is little doubt that a considerable trade will result. 


\section{The Pilchard Fishery.}

Pilchards frequent the coasts of France and Spain in small numbers. The fishery of Nantes is carried on with great activity, and employs in the season 700 boats, manned by about 3000 seamen. 


\section{CHAPTER IV.}

\section{THE MACKEREL FISHERY.}

The mackerel fishery on the coasts of Devon and Cornwall-The Lowestoft mackerel fishery-Statistics of fishery-American mackerel fishery-Mode of curing the fish.

THE mackerel (Scomber scombrus) is a much esteemed fish. The excitement on the Devon and Cornish coasts when the shoals of this fish appear is very great. On their periodical arrivals, which is their custom in multitudes, for the purpose of feeding on a small fry very similar to whitebait, a practised eye will readily observe their manœuvres some distance from the shore, inasmuch as the moment they discover the food they love so well, their numbers and greedy propensities cause them to rush on their prey, which, endeavouring to escape from death, disturbs the water in large circles like a shower of hailstones dropping therein; indeed, we know of nothing more similar to compare it to. The moment one of these disturbed spots appears on the water, men are placed on the highest cliffs to look out, while the boats with their crews and nets prepared are launched and ready for action. The mackerel are sometimes seen at least a mile from shore, but the moment they attack the small bait, the latter fly towards the beach, till at times they approach within a hundred yards or nearer; 
and the look-out man, who discovers them more readily from an eminence, shouts at the extent of his lungs, the boats are rapidly rowed around the feasting fish in a circle, the nets cast, and then being hauled towards the shore by men on land, some thousands of mackerel are enclosed in a large bag at the extremity of the net.

The demand for this fish is so great, that they are rarely to be met with in the towns in the west.

During 1869 the quantity of mackerel taken from Penzance and St. Ives by railway amounted to 71,959 pads, or 1617 tons; to May I, I870, the quantity conveyed from the same places amounted to 40,100 pads, or 87 I tons.

The Lowestoft Mackerel Fishery. - The mackerel voyage on the east coast, even in its best days, was rarely remunerative either to owners or men; more frequently the amount realized barely paid charges for provisions, leaving nothing for wages, or wear and tear of boats and nets. The owners never expected much, and it was more to keep their men in employment, than in anticipation of profit, that this voyage was carried on for many years. In 1854 there were 20 mackerel boats out of Lowestoft; in 1862 these had decreased to three, and their gross earnings averaged only $£ 9$ per boat.

In former years mackerel realized a large price; now the merchants have to compete with very fine fish caught off the Irish coast near Kinsale, and also with the immense numbers imported from Norway. These mackerel are packed in ice, and find a ready market amongst the manufacturing towns, as well as in London. In I874 Yarmouth and Gorleston had a few boats engaged in this fishery for a short time in the autumn; i.e., nearly four months later than the mackerel voyage of former years commenced. In I 875, 3926 long hundred (I20) were caught, the average 
price of the fish being $26 s$. per hundred; total value, $£ 4907$ ios. In 1862 and 1870 the annual take was valued at $£ 9000$.

The average number of boats engaged in this fishery may be stated at about 50 .

Mackerel nets have only about 24 or 25 meshes to the yard, and are not so deep as the herring nets, but they are twice as long-a fleet of mackerel nets, such as is used by the Yarmouth boats, extending to a distance of nearly two miles and a half.

The official returns of the mackerel fishery for Ireland for 1876 showed a gross capture of $1,391,083$ boxes, of six score fish each. The prices varied from $3 s$. to $5 s$. per box, the total amount realized being £IIO,223. The regular mackerel fishing season commences about the middle of March and ends about the last of June. During that period the lowest price obtained was I $2 s$. per box. The average price for the total quantity taken was $16 s$. per box of six score.

The mackerel fishery on the French coast, taking the catch of the years 1873 and 1874 , averages $£ 140,000$ in value. It is principally carried on from the ports of Boulogne, Dieppe, Fécamp, Caen, and Douarnenez. In I 867 the value of the French catch of mackerel was under $£ 100,000$.

The mackerel on the coast of Norway is, as an article of export, comparatively of modern fishery growth. The fishery is carried on along the southern coast from Christiansand to Mandel, during the three summer months of May, June, and July. The quantity exported to Great Britain in 1869 was $3,698,637$ fish, valued at $£ \mathrm{I} 8,1 \mathrm{I} 7$. The average price paid was $2 s$. per score. The boats' crews engaged in this fishery earned about $£ 60$ to $£ 90$ per boat. 
The American Mackerel Fishery.-The spring mackerel (Scomber vernales, Mitch.) is the ordinary mackerel of commerce. The fall mackerel is considered by some naturalists a distinct species, and has been named Scomber grex. The mackerel is not a migratory fish, but draws off into deep water at the approach of winter, and returns to the shallow water near the shores at the beginning of summer, for the purpose of depositing its spawn. The mackerel fishery of Nova Scotia composes one of its largest exports. Besides the catch by the colonial fishermen, about 50,000 barrels more are taken in British waters annually by the Americans, making about 200,000 barrels in all.

On the North American coast a very extensive trade is carried on in pickled mackerel. Every little creek and day from Cape Sable to Halifax in Nova Scotia occasionally overflows with this fish, and they are taken in nets, from 100 to 600 barrels being secured at a single draught. Men, women, and children are then employed night and day in curing them. 150,000 barrels of mackerel are often exported from the port of Halifax alone, principally to the United States, valued at $£ 300,000$. In I 874, 32,000,000 pounds weight of mackerel were taken on the Canadian coasts.

There are about 60,000 tons register of American boats engaged in the mackerel fishery, chiefly from the States of Massachusetts and Maine, and employing I0,000 men. The quantity of mackerel taken by these boats sometimes amounts to 350,000 barrels, valued at $£ 500$,000.

When an American vessel reaches a place where the fish are supposed to be plentiful, the master furls all his sails except the mainsail, brings his vessel's bow to the wind, ranges his crew at intervals along one of her sides, and, without a mackerel in sight, attempts to raise a school 


\section{The Commercial Products of the Sea.}

by throwing over bait. The baiter stands amidships, with a bait-box outside the rail, and with a tin cup nailed to a long handle he scatters the bait on the water. If the mackerel appear, the men throw out short lines, to the hooks of which a glittering pewter jig is affixed. The fish, if they bite at all, generally bite rapidly, and are hauled in as fast as the most active man can throw out and draw in a line. As they pull them on board, the fisherman, with a jerk, throws them into a barrel standing beside him. So ravenously do they bite, that sometimes a barrelful is caught in I' 5 minutes by a single man. Some active young men will haul in and jerk off a fish and throw out the line for another with a single motion, and repeat the act in such rapid succession that their arms seem continually on the swing. While the school remains alongside and will take the hook, the excitement of the men, and the rushing noise of the fish in their beautiful and manifold evolutions in the water, arrest the attention of the most careless observer.

The summer mackerel fishing is carried on in two ways, with hooks and lines, and with the seine. The greater number of fishermen use the hook and line. These are the crews of those beautiful schooners to be met with everywhere in the southern part of the Gulf of St. Lawrence during the months of July, August, and September, and which from afar look more like a small squadron of yachts than a fleet of fishing vessels, so beautiful are their masts and sails, and so neat and clean are they kept. But on a nearer approach this is found to be an error, for on the decks of these vessels are to be seen crews of from to to 20 men, all occupied either in catching fish, in repairing fishing implements, or in splitting and salting fish that have been taken; and what is most striking is the order that 
reigns on board of these schooners, whose decks and holds are almost always full of fish, fish barrels, salt, etc.

Before sailing from their port of outfit for the Gulf of St. Lawrence, they provide themselves with several barrels of very fat little fish, called poggies, to serve as bait and as feed, for the purpose of attracting mackerel to the surface of the water and retaining them near the vessel.

At a later period, when the poggies are exhausted, recourse is had to the offal of the mackerel for bait, and it is prepared in this way :-Whole fishes, or the offal of fishes, either poggies, mackerel, or others, are chopped very fine in a machine something like a chaff or straw cutter, and then put into a large bucket full of salt water ; the mixture is then stirred for a long time with a small paddle, and this is the whole secret of preparing feed for mackerel. Machines for chopping up the fish are sold at from $£ \mathrm{I}$ to $£ \mathrm{I}$ ros., according to their size.

As soon as the schooners have reached the place where schools of mackerel are usually found, they keep cruising backwards and forwards, and the moment there is the least appearance of fish, or their presence is even suspected near a vessel, the jibs are taken in, and the vessel is brought to, with the mizen-sail and mainsail veered half round. Feed is then scattered all around from small pails; the fishermen seize their lines, bait their hooks with small pieces of the skin of the neck of the mackerel or of any other fish (but the mackerel is much preferable), and throw them into the water. The lines are fine, and made of hemp or cotton, generally the latter. They are from six to eight fathoms long, and to one end is fastened a small sinker of polished pewter, oblong in shape, and weighing about two ounces, on which is soldered a middle-sized hook. Each fisherman plies two lines, one in each hand, and leans on the 
rail while fishing. He very seldom pays out more than four or five fathoms of line, for the mackerel, attracted by the chopped fish thrown overboard, thousands of pieces of which float in mid-water, leaves the depths of the sea, and comes swimming towards the surface to feast with avidity on this excellent bait, prepared for him with so much care; and while he is gorging himself with pieces of poggie and mackerel, he seizes the bait on the fisherman's hook, and soon, in spite of his violent efforts to break the iron that is tearing his mouth, and to free himself, he is pulled out of the water and thrown upon the deck, where he dies before long.

The fish are classed by the inspectors into four grades, the third and fourth quality being worth only half the value of No. I. They are packed for shipment in barrels, half quarter, and eighth barrels. Nos. I and 2 are intended for the home markets of the United States and Canada, the lowest quality being principally consumed in the West Indies.

In curing them, the common custom is to dip them in fine salt before salting in the barrels. When this is neglected, the fish adhere together, and become red and tainted. The proper mode of packing is with the flesh side down; this prevents the fish from tainting, and allows all impurities in the salt to settle away from the flesh of the fish. Mackerel are also cured in hermetically sealed tins, but not to a very large extent. In 1873 the quantity so packed was 21,000 cans in New Brunswick, and 10,842 cans in Nova Scotia. 


\section{( 73$)$}

\section{CHAPTER V.}

\section{THE SALMON FISHERY.}

Salmon formerly common in the Thames-Statistics of salmon brought to London-Value of the salmon fisheries in 1871 -Sales at BillingsgateSalmon fisheries of Norway, Canadian Dominion, etc. -Acclimatization in Australia.

AT present one of the most esteemed fish is the salmon (Salmo salor). In the reign of Richard I. (I 197), the Thames is described as containing " remarkably good salmon;" and even early in the present century the Thames abounded with salmon of the finest quality. "Thames salmon" then bore a higher price than that obtained from most other streams, and so copious was once the supply, that in the olden time it was usual to insert a clause in the indentures of London apprentices, that they should not be fed upon salmon more than a certain number of days in the month. Then came the time when the river water became impure. Not only was the population of the metropolis enormously increased, but, being well sewered, its vast network of drains poured their contents (by the authority of an Act of Parliament) into the river. Then gas-works were made, and their ammoniacal water still further poisoned the stream. Against these impurities the salmon could not contend ; they gradually, and at length totally, disappeared from the waters of our queen of rivers. 
It is difficult to obtain accurate statistics of the fish food which is drawn from the sea; we can only guess at it from such data as have been made accessible. The following statistics show the quantities of salmon (in boxes of 120 lbs. each) received and sold in London from 1850 to $187 \mathrm{I}:-$

\begin{tabular}{|c|c|c|c|c|c|c|}
\hline \multicolumn{2}{|c|}{ Years. } & \multirow{2}{*}{$\begin{array}{l}\text { Scotch. } \\
13,940\end{array}$} & \multirow{2}{*}{ Irish. } & \multirow{2}{*}{ Dutch. } & \multirow{2}{*}{ Norwegian. } & \multirow{2}{*}{$\begin{array}{c}\begin{array}{c}\text { English } \\
\text { and } \\
\text { Welsh. }\end{array} \\
72\end{array}$} \\
\hline 1850 & ... & & & & & \\
\hline 1851 & $\ldots$ & I I, 593 & 4I $4 \mathrm{I}$ & 203 & 212 & 40 \\
\hline 1852 & ... & $1_{3}, 044$ & 3602 & 176 & 306 & 20 \\
\hline 1853 & $\ldots$ & 19,485 & $505^{2}$ & 401 & 1208 & 20 \\
\hline I 854 & $\ldots$ & 23,194 & 6333 & 345 & - & 128 \\
\hline I855 & $\ldots$ & I8, 197 & 4101 & 227 & - & 59 \\
\hline 1856 & $\ldots$ & I $5,43^{8}$ & 6568 & 68 & 5 & 200 \\
\hline 1857 & $\ldots$ & I8, 654 & 4904 & 622 & - & 220 \\
\hline 1858 & $\ldots$ & 21,564 & 6429 & 973 & 19 & 499 \\
\hline I859 & $\ldots$ & 15,630 & 4855 & 922 & - & 260 \\
\hline 1860 & $\ldots$ & I 5,870 & 3803 & 849 & 40 & $43^{8}$ \\
\hline 1865 & $\ldots$ & 19,009 & $685^{8}$ & I 479 & 1069 & 868 \\
\hline I 866 & $\ldots$ & 21,725 & 9326 & I 772 & 1632 & I 563 \\
\hline I 867 & $\ldots$ & 23,006 & 54 I I & 1203 & 1296 & 2405 \\
\hline I868 & $\ldots$ & 28,020 & 3487 & 807 & 407 & 1725 \\
\hline 1869 & ... & 20,474 & 8800 & 637 & 696 & 1843 \\
\hline I 870 & $\ldots$ & 20,648 & 9211 & 626 & 852 & 3120 \\
\hline 1871 & $\cdots$ & 23,390 & 7379 & 516 & 1037 & 2953 \\
\hline
\end{tabular}

The aggregate value of the salmon fisheries in I87 I was estimated by the Fishery Commissioners as follows :Scotland, £200,000 ; Ireland, £400,000 ; England, £90,000.

At an average of $\mathrm{I} s .2 d$. per $1 \mathrm{~b}$., or $£ 7$ per box, the value of the 34,457 boxes sold at Billingsgate in 1870 was $£ 24$ I, I99. Besides these metropolitan sales, 8600 boxes of Irish salmon were sold in the midland districts of England, 2880 boxes in Dublin, and 2107 boxes and $3 \mathrm{I}$ baskets sent to Liverpool. The sales at Billingsgate in $187 \mathrm{I}$ were 35,275 boxes, weighing 1764 tons, valued at $£ 246,925$.

The average annual sale of salmon in London may be taken to be $£ 250,000$ in value. 


\section{The Salmon Fishery.}

The main bulk of the salmon caught in Scotland, it appears, is sent to London; but in the case of the salmon caught in the English and Welsh rivers, the bulk is not sent to London, but to the large towns in the immediate neighbourhood of the fisheries.

The salmon fishery in Norway is interdicted between the 14th September and the I4th February. Besides that which is smoked, salted, and consumed locally fresh, about 250,000 lbs. are shipped annually to England in ice, and a small quantity to Berlin. It costs fresh about sixpence the pound, and the annual sales reach a value of $£ 100,000$. The export of salted salmon is from I000 to I 200 barrels. Above $£ 7000$ worth of salmon was shipped from Norway in I869, exclusively for British account. The fish dealers, who come over in fishing smacks, purchase the fish from the fishermen as brought in, put the fish immediately in ice, and despatch the article to the London market direct, or viâ Grimsby.

In New Brunswick the value of the salmon taken is estimated at about $£ \mathrm{I} 60,000$ sterling.

The fishery is very valuable. As many as 40,000 salmon have been caught in the course of a season at the mouth of the St. John, a large portion of which is sent fresh to the United States, and commands remunerative prices. At the entrance to the Miramichi 400,000 lbs. are annually put up, "preserved" for export. There is a great increase in the yield of salmon in consequence of their protection during the spawning season.

Preserved salmon is exported from British Columbia on a large scale, and bears a very high reputation. In 1874 there was barrelled and tinned not less than 14,500,000 lbs., of the gross value of $£ 400,000$ sterling.

The catch of salmon at Oregon in 1874 was an enormous 
one, and the average take by the 13 existing preserving establishments was 15,000 fish per night for 26 nights. It was estimated that during the season $1,250,000$ salmon were taken, weighing on an average $16 \mathrm{lbs}$. each, of which 950,000 were canned fresh, and the remainder salted and barrelled. The following figures give an approximate return, for it is difficult to obtain precise statistics :-

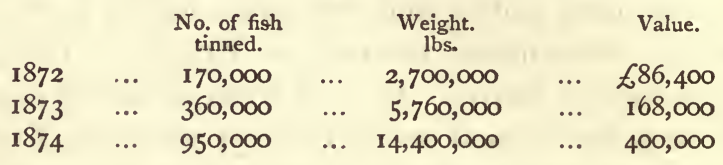

In the last-named year 250,000 salmon, weighing 4,000,000 lbs., were salted. Owing to the enormous increase of production, the market value of both canned and salted salmon has been much lowered. The average price was not over $6 s$. per dozen I lb. cans.

In 1876 , during the fishing season, 18 establishments on the Lower Columbia river put up 428,730 cases of salmon. Of these over 400,000 cases contained four dozen I lb. tins, and the remainder consisted of $2 \mathrm{lb}$. and $2 \frac{1}{2} \mathrm{lb}$. tins. Over I00,000 cases were shipped direct from Astoria to England in the first three months. In 1877 the total catch was 378,325 cases. The total exports from San Francisco by sea to Europe and the colonies were 170,887 cases in 1876 , and 160,982 cases in 1877 .

Attempts have been carried on for many years past, which have been attended with partial success, to acclimatize the salmon in the Australian rivers, and considerable quantities of ova have also been sent out to Tasmania and New Zealand. 


\section{$(77)$}

\section{CHAPTER VI.}

THE SARDINE FISHERY.

Derivation of the name "sardine"-Extent of the French fishery-Mode of preparing the fish for market-Statistics of the fisheries-Dried sardinesThe anchovy - The menhaden, or moss-bunker, prepared in oil in America.

THE purity and delicacy of the little fish (Clupea sprattus, Lin.) which haunts the Bay of Biscay and the Mediterranean is known everywhere ; its excellent keeping qualities, when preserved in oil, enabling it to be transported for an indefinite distance. It has much in common with the sprat in flavour, but also reminds the epicure of the anchovy, which is also common on the Mediterranean and other coasts of France.

There are sardines and sardines, for the family to which this fish belongs includes the whitebait, the sprat, and the pilchard. As they were chiefly found in large shoals on the coasts of Sardinia, they have thence derived their popular name, and this has also been incorporated into the specific name of Clupea sardina, Cuvier. In Italy, however, these fish are known as "sardella," and the anchovy as "sardon."

The sardine fishery is eminently French. It is carried on from the Gulf of Gascony to the east. Quitting the Mediterranean, where they are born, the sardines, on the 
first approach of fine weather, pass in great shoals along the coast of Spain, and reach that of France about May or earlier. In Provence, on the Mediterranean, the fishing, however, commences in March and ends in June, while on the coasts of Britanny it only commences in July, and finishes early in October. The shoal increases as it approaches the north, hence the necessity of often changing the nature of the nets which are used with fisheries.

From Douarnenez to Sables d'Olonne there are about 2500 boats employed in this fishery. Each of these requires about 30 barrels of salted cod roe for bait during the season, and as this sometimes runs up in price to $£ 4$ and $£ 5$ the barrel, this entails a very heavy outlay. Besides which, there are the other numerous ports of Bordeaux, Rochelle, Bayonne, etc., to be supplied.

Two of the largest stations are at Douarnenez and Concarneau. Fleets of boats go out some five miles and spread out their nets, by the side of which some cod-roe is thrown to attract the fish. The nets are weighted at one end, and have corks attached to the other, so that they assume a vertical position-two nets being placed close to each other, that the fish trying to escape may be caught in the meshes. The fish is sold all over France (fresh when it is possible) half-salted, or salted and pressed into barrels, and preserved in oil.

Brought to land, they are immediately offered for sale, as if staler by a few hours they become seriously deteriorated in value; no first-class manufacturer coming to buy such. They are sold by the thousand. The curer employs large numbers of women, who cut off the heads of the fish, wash, and salt them. The fish are then dipped into boiling oil for a few minutes, arranged in various-sized tin boxes 
filled up with the finest olive oil, soldered down, and placed in boiling water for some time to test the boxes, and those which leak are put aside. Women burnish the tins, the labels are put on or sometimes enamelled on the tins, which are then packed in wooden cases, generally containing 100 tins, and are then ready for export. It does not always seem to be remembered that the longer the tin is kept unopened the more mellow do the fish become; and, if properly prepared, age improves them as it does good wine; but if they are too salt at first, age does not benefit them-they always remain tough. The sizes of the tins are known as half and quarter tins. There are two kinds of half tins, one weighing 18 ounces, and the other 16 ounces gross. The quarter tin usually weighs about seven ounces ; but there are larger quarter tins sometimes imported, which tins are still used in France, but seldom seen in England.

Sardines in oil form the most important branch of the trade. It has become immense, and employs large numbers of people. A quarter of a century ago the shipment of sardines in oil from France was not above $£ 24,000$ in value ; but in the last Io years it has ranged from $£ 500,000$ to $£ 750,000$, according to the abundance of the fish. About 4500 boats, registering some 10,000 tons, are engaged in the sardine fishery.

In I 866 the value of the French sardine fishery was a little over 7,000,000 francs. In 1873 it reached $13,757,534$ francs, and, owing to the abundant catch, the price fell to 15 francs the 1000 , against 75 francs the 1000 in 1872 .

In some years the sardines are most plentiful; in others they are scarce. At Douarnenez and Concarneau, the principal centres, 884 boats were employed in 1866 ; and in the month of July these boats caught more than 
I I0,000,000 sardines, the sale of which produced 707,648 francs. By the end of August the fish were so abundant that they were sold as low as Is. $6 d$. the I000, a thing not known for 10 years previously.

In 1873, in the quarter of Auray, the sardine fishery was carried on by 239 boats. The catch amounted to 43, I7,0,000, of which 32,000,000 were tinned, 10, 120,000 were pressed or salted, and the rest locally consumed or sent into the interior.

At L'Orient the catch was valued at $2,730,000$ francs; at Douarnenez, 2,976,55 I francs; at Quimper, I,587,534 francs ; Brest, 29I,836 francs; Morlaix, 48, I 45 francs. Occasionally I I 5,000,000 sardines have been caught in a single season on the French coasts of the ocean.

The French fisheries on the coast of Finistère and Morbihan are of very great importance. Large quantities of sardines, mackerel, and lobsters are caught; and close upon I81,000 fishermen were employed during 1873. In I 87 I-72 the quantity of sardines caught decreased, but during 1873 the catch was good. The value of preserved sardines exported alone from Brest to New York in 1873 was $£ 56,640$.

Of fresh and salt water fish caught, the largest proportion goes by railway to Paris. During the year 1873 the fishing stations at Douarnenez, Audierne, and Guilvince (all on the Finisterre) alone sent by rail to Paris more than 4000 tons of fresh fish, and, strange to say, it can be purchased cheaper in Paris than fish of the same quality at Brest or neighbouring towns.

The sardine frequents the bays and inlets of Gallicia; and in the single province of Pontevedra there are more than 102 stations occupied in salting this fish, which is carried on by females. In $1873,5,000,000 \mathrm{lbs}$. of these fish 
were shipped to Mediterranean ports and the Spanish West Indies. Very few are preserved, the French holding the monopoly of this trade. The fishery is carried on from July to February, but the fish are in the best condition and most abundant in November and December.

Dried sardines ("hosi-ka") in Japan are considered a superior manure, but the price is often too high for poor cultivators to use them. These small fish abound in some of the seas around, so that small boats can hardly make their way through them. They are caught in large shoals to extract the oil from them. This oil is used for burning by the lower classes, but is of very inferior quality, and gives off a good deal of black dense smoke. The residue, after the oil is extracted, is sold for manure. A cwt. of this manure costs about $3 s .6 d$.

The Anchovy is another fish, the capture and cure of which gives extensive employment on the French Atlantic coast and in the Mediterranean. The value of the fish caught on the French coasts ranges from $£ 16,000$ to $£ 20,000$ per annum. The fishery is carried on from May to October. After gutting and removing the head, they are washed and simply placed in barrels, with layers of salt, and a little reddish ochreous earth added to give them a colour.

Anchovies are also caught and salted in Norway, the shipments occasionally reaching 20,000 kegs.

The Americans have begun to utilize the Menhaden, or moss-bunker, by preserving it in oil like the French sardines. This fish has been variously named Brevortea menhaden and Alosa menhaden. The objection to these fish for general use is that they are very bony. The American Sardine Company, by some mechanical process, have removed this objection. 
The preparation these fish go through is thus described: - They are first brought to the scaler, which consists of a long shaft, on which are twelve wheels filled with long blunt teeth. These revolve very rapidly, and take off every scale in an incredibly short space of time. From the scalers they are passed to hands who chop off the heads and cut out the entrails. They are then placed in the washing troughs, above which are a number of revolving circular brushes, by contact with which the insides are thoroughly cleaned. They are then deposited in pickle vats, where they remain for a few hours, until they are sufficiently salted; after which they are spread upon large tables, and placed in cooking cans. They are then taken to the steaming tanks, of which there are seven, each having a capacity for holding 1000 boxes. From the steaming cans, they are again taken to the tables and transferred to the permanent cans, when they are oiled and spiced, and then handed over to the tinsmiths to be soldered. The time from the fish being brought to the factory until they are boxed and labelled, is three days.

Now these fish are shipped in large quantities to every part of the States, and by many are considered quite equal in flavour to the sardines imported from France to Italy. 


\section{$\left(8_{3}\right)$}

\section{CHAPTER VII.}

\section{THE TUNNY FISHERY.}

Tunny fishery in the Mediterranean-Size the fish attains-Description of a "madrague "-Statistics of the Italian fishery-Definition of terms usedScabeccio, or tunny preserved in oil-Salted tunny-Fishery at Tunis and Algeria.

THE tunny (Thynnus vulgaris, Cuv.) is a common fish in the Mediterranean, and has been known and celebrated from the remotest antiquity. The Mediterranean is, of all the seas, that least abundant in variety of fish, only nourishing about 440 species.

In Sicily the tunny forms one of the most considerable branches of the commerce of the island. In France it is much used, and is cooked in a variety. of ways. It is frequently taken on the Atlantic coast, but must be considered a wanderer from more southern latitudes, and is there known by its popular name of "horse mackerel and albicore." In America its flesh is not held in estimation.

On the shores of the Mediterranean Sea it is found in great abundance, and forms one of the chief sources of wealth of the seaside population. The flesh is highly esteemed, and eaten both fresh and salted. It is extensively used in the Italian countries, pickled in various ways, boiled down in soups, and made into pies, which are thought to be very excellent, and possess the valuable 
property of remaining good for nearly two months. The different parts of the fish are called by appropriate names, and are said to resemble beef, veal, and pork.

The shape of the tunny is not unlike the mackerel, but it is larger, rounder, and has a shorter snout. The general average length is about four feet, but sometimes it attains a length of IO or 12 feet. One was recently caught in a mackerel net off Martha's Vineyard, and exhibited by Eugene Blackford, at Fulton market, New York city, that weighed over $700 \mathrm{lbs}$., and was $\mathrm{I} 4 \mathrm{ft}$. IO in. in length. De Kay, in his work, mentions one that was taken near Cape Ann that weighed about I000 lbs. These are the largest tunny fish caught in America of which we have any information.

In May and June the tunnies move in vast shoals along the shores of the Mediterranean, seeking for suitable places to deposit their spawn. They are seen by sentinels, who are on the watch, and nets are prepared for their capture. These nets are of two kinds, one a common seine and the other called a "madrague." The outer portions of the madrague intercept the fish, and on their endeavouring to retreat they are forced to enter one of many chambers. They are thus driven from one chamber to another until they are forced into the last and smallest, which is significantly called the "chamber of death." This chamber is furnished with a floor of net, to which are attached a series of ropes, so that by hauling on the ropes the floor is drawn up and the fish brought to the surface. They struggle fiercely for liberty, but are speedily stunned by blows from long poles, and lifted into boats. From 5000 to 6000 tons of tunny fish have been shipped in some years from Elba.

The tunny fisheries, which supply the labouring popu- 
lation of the Sicilian coasts during the summer months with employment and food, generally yield more than enough for home consumption. The surplus, preserved in oil or salt, forms, together with anchovies, sardines, and sturgeons, a considerable article of export from' Sicily. In I 866 the fishery carried on in the "parages" of the Isle of St. Pierre, situate on the south coast of Sardinia, yielded I5,850 tunny fish, weighing nearly 3,000,000 lbs., and approximately valued locally at $£ 51,000$. In 1869 the shipments amounted in value to about $£ 25,000$, in I 870 to $£ 22,000$, and in 1871 to about $£ 35,000$. This fish is exported to England, the north of Europe, to Italy, and also to Greece and Turkey.

The fishery occasionally employs at Palermo I000 boats and 3500 men.

The produce of the tunny fishery at Caloforte, Italy, in I 874 was :-

$\begin{array}{cccccr}\text { Tunny in oil } & \ldots & \text { Kilogrammes. } & & & \text { Francs. } \\ \quad, \quad \text { salted } & \ldots & 18,400 & \ldots & \ldots & 590,400 \\ \text { Eggs and entrails } & \ldots & 22,230 & \ldots & \ldots & 9,800 \\ \text { Tunny oil ... } & \ldots & \frac{30,850}{372,480} & \ldots & \ldots & 24,200 \\ & & & & & \frac{36,000}{660,400}\end{array}$

The value of the fishery in I 873 was as high as $4,248,700$ francs (about $£ \mathrm{I} 70,000)$.

The tunny fishery of 1875 from Cagliari, though better than that of 1874 , was below the average yield, the value of the products not reaching $1,000,000$ francs.

The exports of tunny fish salted and pickled from Sardinia in twelve year's were as follows :-

$\begin{array}{crlccc}3 \text { years ending } & 1854 & \ldots & \ldots & \ldots & 3,777,280 \\ , . & 1857 & \ldots & \ldots & \ldots & 7,596,904 \\ , " & 1860 & \ldots & \ldots & \ldots & 3,493,013 \\ , & 1863 & \ldots & \ldots & \ldots & 2,152,453\end{array}$


For the last seven or eight years the "matanzas," or takes of tunny, at Tunis have proved very equal and good, Were the fish to exceed I4,000 in one season, they would be beyond the preserving and curing capabilities of the establishment. The nets are laid jutting out to sea for upwards of a mile, and are so placed as to form several chambers; the outer compartments are made of esparto grass-rope nets, of very large meshes, which gradually decrease in size as the "corpo," or slaughtering compartment, is approached. The nets in this part are made of the finest hempen cordage.

The tunny, in their annual spring migration from the ocean to the Archipelago and the Black Sea, follow either the southern or northern shores of the Mediterranean in all their windings. A tonnara is so constructed off a promontory or headland as to offer an obstruction to the fish, which, in endeavouring to avoid it, enter compartment after compartment. Their migratory instinct is so strong, that they never appear tempted to retrace their course, but always endeavour to find a way out towards the east, which is barred to them.

On a sufficient number of tunny fish being noted in the "corpo," a net is lowered at its entrance, and the net, which forms the bottom of it, is gradually drawn up towards the surface, so as to bring the fish within the reach of the men, the majority of whom, about 160 in number, are in two immense lighters, armed with harpoons and boat-hooks, by means of which the tunny are killed and drawn into the barges. A few of the men are also in small boats in the centre of the enclosure. As many as 700 fish are occasionally secured in a single " matanza," but more usually from 400 to 500 . "From 30 to 35 days are expended in laying down the nets and otherwise preparing for work. 
The first "matanza" of the season generally takes place about the Ioth of May, and the last on the 3oth of June, or thereabouts. To secure the high prices of an early market, the first "matanza" is hastened as much as possible, and takes place if even 200 , or only 150 , tunny have entered the "corpo."

The fish are killed and landed in the morning, and allowed to drain until the evening, when they are cleaned and cut up. The "scabeccio"-tunny preserved in oilis boiled for an hour, and then allowed to cool and dry, when it is quickly packed in barrels already prepared for its reception, and about a third of a "metal " of oil ( $1 \frac{3}{4} \mathrm{im}$ perial gallon) is poured into each barrel, great care being taken that it should permeate the whole contents, and that no vacuum should exist when closed. The same process is observed for the tunny preserved in tin cans, only that the air is more thoroughly excluded and exhausted by steam power. The operation of salting the fish is more expeditious, for, whilst the "scabeccio" to be prepared requires from four to five days, the salting takes but a day or a day and a half. The oil extracted from tunny is much used by curriers and in the tanning trade, and is extracted from the heads, dorsal and other bones, and refuse, the whole being placed in an immense cauldron, capable of holding 800 heads and 400 skeletons at a time, and allowed to boil for 24 hours. The bones after boiling are subjected to compression in powerful presses, and thus but little of the oil they contain is lost.

In a good season the Sidi Daud fishery, Tunis, furnishes from 10,000 to 14,000 tunny, but they vary considerably in size from one year to another. In I 870 the fish were larger than those of 187I, although some of the tunny caught measured eight and a half feet in length, and four feet in 
diameter at the neck, the widest part of the body. From 2000 to 3000 fish are sufficient to pay the whole of the expenses of a season. The average yield is for 1000 fish to produce $\mathrm{I} 2 \mathrm{O}$ barrels of "scabeccio."

In I87I, 3200 barrels of "scabeccio" were made, and sold at more than $£ 6$ Ios. the Ioo kilogrammes; and 90,000 kilogrammes of tunny were put up in tin cans, which realized more than $£ 8$ the 100 kilogrammes. Eight thousand barrels of salted fish were sold at about $£$ I $4 s$. per barrel ; and 40,000 kilogrammes of oil $(65,460$ imperial gallons) produced more than $£ 40$ the 1000 kilogrammes. Two thousand "metals" (about 10,250 imperial gallons) of the best olive oil were expended in the preservation of the above quantities of fish.

Very few of the fish are sent in a fresh state to the Tunis market; about 50 only are presented by the proprietor to the Bey, local and foreign authorities, and other Tunisian officials. The roes, milts, hearts, sounds, and all other coarse parts of the fish are the perquisites of the fishermen, and are preserved and sold on their own account. The roes are chiefly sent to Italy, and are there sold at from $2 s .6 d$. to $4 s$. the pair. Upwards of 200 barrels of inferior parts of tunny were salted on account of the men in $187 \mathrm{I}$.

It appears, moreover, that the demand for preserved tunny is at present limited to the countries bordering on the Mediteranean, and the ten tonnaras in Sicily, one in Calabria, six in Sardinia, and one or two in France, Spain, and other parts of Italy, produce sufficient for actual requirements. In Germany tunny is beginning to be known and called for, but it took six months last year to dispose of 200 tin boxes that were sent to England as a commercial experiment. Nevertheless the best qualities 


\section{The Tunny Fishery.}

of tunny only require to be better known in England to be highly appreciated. 1870 and I87I proved disastrous seasons for the Italian tonnaras, the tunny fish having, unaccountably, almost entirely failed to make their accustomed appearance, and the two most famed tonnaras of Trapani only secured 2000 fish each in I87 I, whilst others were forced to break up their establishments from want of success, before the season was half over.

Tunny fish preserved in oil ("scabeccio") is much used; the price is about $£_{3} 5$ s. the cwt., and the produce of the fishing in $187 \mathrm{I}$ was-

\begin{tabular}{lrrrr}
\multicolumn{2}{l}{ Scabeccio preserved, in barrels } & $\ldots$ & $£ 10,336$ \\
Salted tunny $\quad \ldots$ & $\ldots$ & $\ldots$ & 10,200 \\
Scabeccio in tin cans & $\ldots$ & $\ldots$. & 7,200 \\
Tunny oil ... $\quad .$. & $\ldots$ & $\ldots$ & 1,600
\end{tabular}

The export of tunny fish from Tunis in 1873 was :-

$\begin{array}{lrrrrr}\text { Salted, to the value of ... } & \ldots & & \ldots & £ 644 \\ \text { Pickled in oil } & \ldots & \ldots & \ldots & 4 \text { 'r } 3\end{array}$

This fishery might be profitably carried on in Algeria. Arzeu has one small madrague, where on some days as many as 300 tunny fish have been taken. 400 or 500 persons could be profitably occupied in this fishing. A madrague established at Sidi Feruch, or at Cape Matefou, would give during the season, at each lift of the nets (an operation which might be renewed several times during the week), 300 or 400 tunny fish, weighing from $60 \mathrm{lbs}$. to 600 lbs. It might be salted or marinated, and as this fish will keep fresh for a week, it might be shipped to supply the Marseilles market. It could only be carried on during the months of March to June. 


\section{CHAPTER VIII.}

\section{CRUSTACEA.}

Useful or food-supplying crustacea-The lobster-The British fishery-Size to which lobsters grow-Technical names by which they are sold in Billingsgate-Supply of crabs-Crab-pots-Lobster fishery in America-Change of colour in boiling-Statistics of the trade in canning lobsters, etc. The Norway lobster fishery.

Among the crustacea we have the useful or foodsupplying kinds, such as the boiled lobster and the canned or tinned lobster; the edible crabs of the market, used for food, and the king-crab for manure; large prawns, used in place of the lobster on the west coast of America; those sold in the markets of Europe, at New York, and the east and south coasts of America; the smaller shrimps and prawns, held in esteem by various nations, and many of which serve for bait. The liquid fat of the hermit-crab (Pagurus sp.), under the name of "manteca de ladron," is used in Venezuela to cure laxations of the bowels.

The shell of the king-crab (Limulus polyphemus) is used on the American coasts as a boat-bailer.

Of the crustaceans, the lobster is that which is most in demand, although the more common crab is, of the two, most digestible and nourishing. But the lobster has always been held in estimation as a food delicacy, and from being so sought for, leads to a very extensive commerce. Besides 


\section{Crustacea.}

the British supplies-of which we have no very reliable returns - the bulk of our imports come from Norway and Sweden, and it may be interesting to glance at the statistics of the trade generally.

The British Fishery.-Lobsters are brought to Greenock in large numbers from the western islands, chiefly from Skye, in boxes containing from four to five dozen, and are there transferred, for facility and economy of carriage by rail, to tea chests, into each of which from 50 to 100 fish, according to size, are carefully packed, and forwarded regularly and in large quantities in this way to Liverpool, Manchester, Birmingham, and London, in each of which towns is located a branch of a great firm-originally of Aberdeen-to whom are continually consigned enormous quantities of fish from all parts of the coast. Much more might be done on the coasts of the British Islands in the matter of lobsters, especially in Ireland. In a report on the Irish Fisheries, it was stated that- "Lobsters may be taken in any quantity; 20,000 or 30,000 a week might be easily captured on about 20 miles of the coast of Clifden, Buffen Island, and Bunown, but the people have no means of taking them. They only fish close to the shore, and large lobsters cannot go into the pots used. Those of five or six pounds or eight or nine pounds weight are only taken by clinging to the sides of the pots; and if the fishermen had boats sufficient to go out to the rocks seven or eight miles off, they, with proper gear, would take the finest fish in the world, and in the greatest quantities. They may be had in season every day in the year that men could venture out to set the pots, but they never do so in the winter." The size and age to which lobsters sometimes attain was evidenced by one caught a few years ago in Plymouth Sound in a trawl net, which was reported in the Field of June 2nd. Its length was, from the 
tip of the claws to end of tail, $3 \mathrm{ft}$. 2 in.; weight, $15 \mathrm{lbs} .2 \frac{1}{4} \mathrm{oz}$. Several small oysters, mussels, and barnacles were adhering to the shell, and it was supposed to be Ioo years old, although what grounds there were for the assumption were not stated.

Crabs and lobsters are supplied to the London market from the east, south, and west coasts of England, from Cornwall and the Channel Islands. The crayfish nearly all come from Sennen Cove, near the Land's End, and the greater part of these are sent to France. The crabs received from Dunbar are very small, some of them not more than three inches across; they are called in the market "Dunbar bugs." Very small crabs are also received from Scarborough; one dealer in the season receives about 20 barrels per day, each barrel containing 200. After paying expenses and carriage, it is calculated that the fishermen can only realize $4 s$. for 200 crabs, and $20 s$. for 100 lobsters. Crabs are much wanted for the seaside markets in August and September.

Lobsters are sold in Billingsgate by curious ancient terms, viz., a "worst Nancy," which equals 40 small lobsters; a "best Nancy," which is 40 lobsters of a larger size. According to sizes above this, lobsters are sold by a "best Double," a Score, and a Ten.

The supply of crabs to London has diminished more than half, both in size and number. Many crabs come from the West of England, Cornwall, and Devon. The price has gone up fully 30 per cent.; a crab eight or ten years ago worth $2 s$. is now worth $3 s .6 d$. The sale for crabs begins to fall off in October, and does not begin again till March. The chief time for the sale of crabs and lobsters is May, June, July, and August. In winter the crabs are watery. Crabs and lobsters are in best condition in warm weather. 
The crabs at Cromer and the neighbourhood are counted by a peculiar standard. Thus, two crabs are counted as one, the two crabs being called "a cast;" six score of crabs is called a hundred; therefore 100 crabs is strictly 240.

There are about 50 boats, each worked by two men, used by the Cromer fishermen. Each boat would set from 30 to 35 pots. These crab-pots cost about $8 s$. A good catch for a boat in two tides' fishing would be about 180 crabs. Supposing the 50 boats had good luck, they would catch about 9000 crabs a day. Sizeable crabs are sold in the Norwich and London markets at the average of 50 s. the long hundred, or nearly $3 d$. each. At Sherningham there are about $100 \mathrm{crab}$ boats, and each boat has about 20 pots.

The crab-pots are set out to sea from the foreshore to the distance of about two miles. The extent of the united Cromer and Sherningham crab fisheries is about eight and a quarter miles long by two wide.

The crab-pots are made of a cage of thick, strong netting, fastened across bows of iron or wood. This cage is I ft. 9 in. long, and I ft. 3 in. across the bottom. The crabs enter the pots through two funnel-shaped doors, which act on the principle of a mouse-trap; a side door can easily be let down, and the crabs removed. The bait used for catching crabs are flat-fish, usually called "butts." The small crabs called "toggs" are also much used, smashed up, for bait, and are sold in large quantities, scarcely fetching a penny each retail, to the great injury of the fishery.

The crab and lobster fisheries of Ireland continue to be pretty productive; but with a view to their better preservation, regulations have been laid down, limiting the size of crabs to be taken to five inches in length across the back at 


\section{The Commercial Products of the Sea.}

their greatest measurement, and lobsters to nine inches from the end of the tail to what is usually called the tip of the beak.

Lobsters used to be taken in great numbers near the village of Usan, near Montrose, and 60,000 or 70,000 were sent annually to London, and sold at the rate of $2 \frac{1}{2} d$. apiece, provided they were five inches round the body; if less, two were allowed for one. The home supply of lobsters is not now, however, so large as the foreign supply.

The supply to London has fallen off very much these last few years; the price has risen considerably, as compared to what it was formerly; the scarcity is beginning to be felt. Lobsters arrive in London from Scotland, Southampton (where they are kept alive), Norway, Sweden, Ireland, and France. The Norway lobsters are considered very good, and so are those from the Orkneys.

The lobster is never so good as when in the condition of a berried hen. Berried hens occur most frequently in April, May, and June. They begin to lose their berries or eggs about July, but still many berried hens occur in July. The use of the berries is almost entirely devoted to cooking ; they are used in many preparations by the WestEnd cooks, especially for the colouring and enriching of sauces. The "chefs" are also fond of coral out of the body of the lobster.

Occasionally, in the month of May, as much as six ounces of berries will be taken from a lobster weighing three to three pounds and a half. There are about 6720 eggs in an ounce of lobster spawn.

The Norwegian lobsters are best in season in May to August ; the Scotch lobsters begin to fall off in August. The shell of the Scotch lobster is thick, and when boiled is of a dark colour, and covered with white specks. The 
shell of the Norwegian oyster is thin, and of a bright red colour.

The Lobster Fishery of America.-Lobster fishing has been followed at Marshfield and Plymouth, Massachusetts, for 30 years and more. From 50,000 to 100,000 lobsters are taken annually, and sold to the smacks for the Boston market, and to pedlars for the inland.

On the North American coasts a large trade is done in putting up lobsters in tins. For some years past the packing-houses of Portland, Maine, have shipped lobsters in tins to England in ever-increasing quantites. The taste thus acquired has created a demand for the article in a fresh and more palatable state. To supply this demand, the Portland firm of Marston and Sons, extensive dealers, conceived the idea of shipping live lobsters by the British steamers which ply between Liverpool and that port. The efforts made in that direction have not, however, been very successful, the number transported which reached their destination alive being very small. The packing of lobsters in America has become so enormous that, at the present rate of canning, serious apprehensions are felt in some quarters that the supply will not last many years longer. A few years ago it was not uncommon to catch lobsters weighing from 10 to 20 pounds each; now the average is from three to six pounds, and growing less, thousands which are caught weighing but little over one pound each.

Quite a fleet of small vessels is employed in this important branch of commercial industry. The Americans having almost denuded their own coast of this useful and valuable crustacean, are now busy fishing for it on the British Atlantic coasts.

Prior to the year I869, no mention is made in the Canadian Fishery reports of the yield of lobsters. 
In that year 52,400 one-pound cans or tins were put up in Nova Scotia. In 1870 the quantity preserved was more than ten times as great, namely, 553,000 cans, valued at about $7 \frac{1}{2} d$. each. In $187 \mathrm{I}$ the quantity preserved in that province rose to 905,500 tins. In the next two years the export trade had wonderfully increased, yet the wholesale price ran up to $I s$. per tin.

The whole quantity preserved in Nova Scotia was returned at-

$$
\begin{array}{ccccccc} 
& & \multicolumn{3}{c}{\text { Tins. }} & & \multicolumn{1}{c}{\text { Value. }} \\
1872 & \ldots & \ldots & 2,422,508 & \ldots & \ldots & £ \text { 121, I15 } \\
1873 & \ldots & \ldots & 3,462,298 & \ldots & \ldots & \text { 173, I15 }
\end{array}
$$

In New Brunswick only 38,500 cans were put up in 1869 ; in $187 \mathrm{I}$ the quantity had increased to 224,000 tins, and in the two subsequent years the advance was as follows :-

$$
\begin{array}{ccccccc} 
& & \multicolumn{2}{c}{\text { Tins. }} & & \multicolumn{1}{c}{\text { Value }} \\
1872 & \ldots & \ldots & \mathbf{1}, 055,485 & \ldots & \ldots & £ 27,740 \\
1873 & \ldots & \ldots & \mathbf{1}, 387,700 & \ldots & \ldots & 69,400
\end{array}
$$

The business of "canning" lobsters is annually extending, and threatens the annihilation of the beds, but it is now proposed that no lobsters shall be taken with the eggs attached, or weighing less than one pound and a half. By this means the destruction will, it is hoped, be limited, and the same error which was committed in the case of the salmon fisheries prevented.

In I 873 more than $4,000,000$ one-pound tins of lobsters were sent from British North America into the markets of the world. In 1874 the value of the lobsters preserved was $£ 203,000$, besides the fresh ones sent to the United States, valued at $£ 24,000$.

In some parts of the Gulf of St. Lawrence they are so plentiful that, notwithstanding their increased commercial 
value since the foundation of this new industry, good marketable lobsters are used to manure the fields.

The proprietor of a large establishment at Shippagaw writes: "The heavy gale of August, 1873, drove more lobsters ashore within five miles of my packing-houses than I could make use of during the whole summer. They formed a row of from one to five feet deep, and I should estimate them at an average of 1000 to every two rods of shore."

Lobsters are taken in wicker baskets, called lobster-pots. These are about three feet long and two feet wide, of a semi-cylindrical form; that is, the bottom flat, and the sides and top in the form of an arch. At each end is an opening for the ingress of the lobster ; around this opening are placed short, flexible pieces of wood, projecting into the basket, so arranged that they will easily separate and allow the lobster to enter, but their points close together after him and prevent his egress. They have a door upon the top, through which the lobster is taken out. A long line is attached to these pots; a heavy stone, sufficient to sink it, is placed inside. They are baited with the heads or offal of fresh fish, and sunk to the bottom at about lowwater mark; the other end of the line is made fast to a block of light wood, called a buoy. The fishermen go out with their wherries freighted with these pots, and drop them at short intervals along the shore. During the season of lobster fishing, which lasts from March to July in America, hundreds of these buoys may be seen bobbing up and down like so many seals' heads. The fishermen visit them every morning, draw them up alongside of their boats, take out the lobsters, replenish the bait, and drop them again into the water. The lobsters, when first taken, are very fierce, and seize with their strong pincers upon 


\section{The Commercial Products of the Sea.}

whatever may be within their reach. When thrown together in the boat, they will grapple and tear off each other's feelers and legs. Without much care in handling them the fingers of the fishermen get many a hard bite. To prevent them from injuring each other, the fishermen provide sharppointed wooden pegs, which they insert into the joint or hinge of their pincers; this prevents them from closing. When they have visited all their pots they row to their landing-place. If they now wish to preserve them for several days, they put them into a long box or kennel, made of plank, and bored full of holes, which is moored in the water at a little distance from the shore. If they wish to prepare them immediately for market, they are taken ashore in hand-barrows and carried to a sort of shed, in which is fixed a large cauldron in which they are boiled.

The cause of the change of colour in the crustaceans after boiling has been investigated by several scientific inquirers. It is found to be due to two or three pigments, scarlet, blue, and green. The lobster, crayfish, and crab take a vermilion hue; the prawn acquires a bright rose colour, and the grey shrimp a slight rose tint, bordering on violet.

There are now about 67 canning establishments in Nova Scotia and New Brunswick, which use up from three to five tons each per day in the season, which lasts from four to six months, making a total annual destruction of at least 30,000 tons. Every season the number of canning establishments is increasing, and of course the destruction will increase proportionately. As no supply, however large, can stand a ceaseless and increasing drain, unless means are taken to supply the waste, it is evident that this valuable supply must soon become exhausted by over-fishing.

The whole of the edible part of the lobster is not 
utilized by the curers, who say that the trouble of picking out the flesh from the claws is too great, and that lobsters are too cheap to make it worth while to go to the expense of this slight additional labour.

Lobster Fishery in Norway, etc.-There are many other countries where the business of preserving lobsters in tins might be profitably carried on-Norway for example. From the port of Stromstad, in Sweden, about 50,000 are also sent annually to England.

The Norway lobster is the Nephrops Norvegicus. This crustacean is caught in the fiords from the southern extremity up to the Lofoden Islands; but it has been noticed for some years that there is a tendency in the lobster to keep more towards the north, where they are found of larger size. They are often taken by means of a common cask, the bottom of which is replaced by boughs, and a hole is left for the lobster to enter, attracted by the bait of the fresh herring suspended, but it cannot get out again. Osier pots are also used, but of a more oblong shape than those employed with us. The trade is pretty much centralized at Christiansund. The lobsters are there placed in large reservoirs made in the centre of the fiord, where they are kept alive until despatched to Belgium and England. A part are sent off in wooden boxes, and others in quick-sailing vessels, with holds having reservoirs capable of holding 10,000 to 12,000 lobsters, the sea water passing freely through holes pierced in the ship's side.

The commerce in lobsters in Belgium is not in a very good state. In I87I several cargoes were imported from Brittany; but these lobsters are larger than those of Norway, and the flesh is not so good, and yet they sell at a somewhat higher price. The whole of the fishery in Norway is monopolized by English speculators, so that it is 
I00 The Commercial Products of the Sea.

difficult to buy a lobster, excepting of a diminutive size without breach of contract, or paying comparatively an exorbitant price.

The number exported annually from Norway ranged in the early part of the century from 600,000 to 800,000 ; from I 825 to I 829 it was higher, reaching an average of I,280,000; in $1848,607,282$ were sent away. The annual export from I 853 to I 859 was about 800,000 . In the ten years ending with 1870 the average number shipped was $1,500,000$. In the last five or six years the number has fallen somewhat below $1,000,000$.

The number of lobsters exported was in-

$\begin{array}{rrrrrr}1870 & \ldots & \ldots & \ldots & \ldots & 1,207,194 \\ 1871 & \ldots & \ldots & \ldots & \ldots & 1,045,063 \\ 1872 & \ldots & \ldots & \ldots & \ldots & 899,708 \\ 1873 & \ldots & \ldots & \ldots & \ldots & 919,944 \\ 1874 & \ldots & \ldots & \ldots & \ldots & 749,074 \\ 1875 & \ldots & \ldots & \ldots & \ldots & 880,630 \\ 1876 & \ldots & \ldots & \ldots & \ldots & 1,270,348\end{array}$

The lobster is the largest and most useful of the crustaceans of Europe. It is met with along the whole coast of Norway up to the Arctic circle, in the sea and in the fiords, but especially between Christiania and Loudmore.

The fishery for lobsters is well regulated on all the coasts of Sweden and Norway as far as Molde. It is prohibited between the I5th July and I5th October. Each boat has about 30 bow-nets, and wooden cases with openings at each end, having the form of elongated casks. They are sunk about 38 fathoms deep by means of stones, after being baited with waste fish, and are examined night and morning. The claws of the lobster are fastened that the animals may not injure each other, and they are shipped in fast-sailing, welled vessels that hold from 15,000 to 20,000 . About $3,000,000$ are taken annually in Norway 
and Sweden; these are sold at $3 d$. to $6 d$. each, according to size. Those less than eight inches, or which have lost a claw, are only worth half this price, and they are now prohibited to be sold.

The Cape lobster (Palinurus Lalandii, Lam.) is used as food by the colonists. It is peculiar to the west coast, and common in Table Bay; is easily caught in vast numbers all the year round, and attains a length of $\mathrm{I} 3$ inches and a breadth of nearly five inches. The flesh of the half-grown individual is tender and delicate, but that of the adult is coarse and difficult of digestion. To the poorer classes this crustacean is a regular godsend, and it is occasionally dried for preservation.

A part of the west coast of New Jersey, not far from Cape May, is infested in May and June by swarms of huge inedible crabs, and these are collected and ground up for manure. As to their eggs, one may almost say that the sand of the beach consists of their eggs, for they are scooped up by the bushel and thrown to the pigs and poultry.

A large number of fine crabs are caught on the coasts of Norway, which only cost about $\frac{1}{2} d$. or $\mathrm{I} d$. each on the spot. They are met with in incredible numbers in the fiords on the west coast, especially where it is rocky. There are often 40 or 50 taken at a time in a cask or crab-pot, and they are frequently I I inches long. The crab is not eaten by the coast populations, and it sells at a very low price, even in the markets of Bergen and Stavanger. Crabs are chiefly used cut up for fish bait. Lately an attempt has been made to preserve them in tins for export, and specimens were sent to the Paris Exhibition in 1878 .

A fishery for small crayfish is carried on in the bays of the river Konki, in Russia, and the tails are dried for sale. A pound will contain about 300 of these pieces. 
IO2 "Yhe commercial Products of the Sea.

Various crabs, crayfish, and prawns are regularly collected, and eaten or sold as food by the natives of India. All the species thus used are, however, caught in lagoons or fresh-water lakes, with the exception of some land-crabs. Prawns in Madras are usually avoided by Europeans, as they are mostly caught in the river Cooum, which is little else than a common sewer. Some of the crabs are pleasant to eat, but not always safe. Among those eaten are Lupa sanguiloneuta, Desm., and L. Tranquebarica, Edwards, and Thelphusa Leschenaultii.

Crayfish and lobsters are very abundant on the west coast of South America. At Juan Fernandez they are found in such large quantities that the fishermen have no greater trouble to take them than to strew a little meat or bait upon the shore, and when they come to devour it, as they do in immense numbers, to turn them on their backs with a stick. By this simple method many thousands are taken annually; and the tails, which are in high estimation, are dried and sent to Chilca.

At Marennes, in France, the fishery for shrimps brings in a return of $£ 500$ a year.

The British Shrimp Fishery.-Shrimping is pursued extensively on many of our sandy coasts.

The chief occupation of the Leigh fishermen is catching shrimps. This they do throughout the summer months. The smaller boats continue to catch them during the winter; but the larger vessels, when the demand for shrimps falls off, go farther away to sea, hand and long lining for cod, or fit out with stow-boat gear for catching sprats, or go trawling. They fish during winter about the Swin, the Barrow Deeps, the Waleet, and other places, remaining at sea for weeks together; but in the summer their practice is to go out one tide and return the next; 
and a very pretty sight it is to see this little fleet of I 50 vessels all working in and out of Leigh Creek together, boats of all sizes, and sails of every cut and colour, and if it be about sunrise or evening time when this happens, it makes a most charming picture.

Shrimps are caught all over the sands that lie in the Thames estuary. The manner of catching them is this. An apparatus is constructed in the following manner :-A frame of wood about six or eight feet long (it may be of any size) is formed, and upon this is placed a net, in such a manner that the net and frame, when complete, shall form a long-pointed bag; to the wooden frame is attached a long rope, by which it is lowered to the bottom, and when there dragged along by the motion of the boat through the water. The edge of the wooden frame scrapes along the sand and compels the shrimps to enter the net; when in, they quickly get back to the end of the pocket, where the mesh is fine, and they are secured. Each boat is provided with three or four of these little trawls. At Gravesend, where there is also a large fleet of craft employed in shrimping, they use a much larger description of net, and each boat is sufficiently equipped with one of these.

Shrimping boats must be provided with a well, in which the shrimps are placed the moment they are caught. As soon as they are taken from this well, on the arrival of the boat at Leigh, they are placed in a copper of boiling sea water and boiled at once; when cool, they are forwarded to London as quickly as possible.

As many.as 1000 gallons of shrimps are sometimes sent to London in a single day from this place alone.

Shrimps and Prawns, etc., in other Countries.-Prawns at Tunis are of great size, six to seven inches long. Tunis, the ancient Carthage, was always celebrated for them, and 


\section{I04 The Commercial Products of the Sea.}

the Roman emperors used to send for them for their banquets.

Shrimps are collected in large quantities on the east coast of Norway. One species (Pandanus borealis), distinguished by its red colour and great size, being three or four times larger than the ordinary shrimp, is fished for exclusively at Svelvig, and sold at Drammen, where it is much sought after.

Large quantities of dried shrimps form an important article of consumption and export at Maranham, in Brazil. In the eastern countries, as in India, there is a large commerce in them; and a shrimp powder is also used as food there, composed of dried shrimps pounded up with salt, spices, etc. The species used are Penceus affinis and another species. From the port of Chefoo, China, 6500 to 8500 cwt. of dried prawns are annually exported. From the port of Newchwang there was sent to other Chinese ports, in $187 \mathrm{I}$, nearly $2000 \mathrm{cwt}$. of dried shrimps and 300 cwt. of shrimp husks. From Manila large quantities are also shipped.

Only a few Australian crustacea are applied to any use. The Great Murray River crayfish or lobster (Astacoides serratus) is brought in great numbers to market, and is generally used at table as the lobster is in Europe. The smaller crayfish (Astacoides quinquecarinatus) is not sold in the markets, but is commonly eaten in the vicinity of the many streams and rivers in which it is found in abundance. The great marine spiny crayfish or lobster, found abundantly at the Port Phillip Head, is constantly exposed in the shops and used at table in salads, etc. It seems to be a variety of the Homarus annulicomis, or a very closely allied species. 


\section{( 105$)$}

\section{CHAPTER IX.}

THE TREPANG FISHERY.

Trepang or bèche-de-mer fishery in the Pacific and Eastern Seas-Numerous varieties of Holothuria-Mode of preparing for market-Process of drying-Statistics of exports from the Fiji Islands and Tahiti-Large imports into China.

AN important fishery for a food product, although one scarcely known at all in Europe, is the trepang fishery of the Pacific and Eastern Seas.

The trepang, or bèche-de-mer as it is sometimes called, is a most unsightly looking substance, a kind of sea-slug, belonging to the genus Holothuria. There are many varieties. The ordinary kind in point of size and appearance resembles a prickly cucumber, except that the colour is of a whitish brown ; another is perfectly black. Sometimes they are found nearly two feet in length, but they are generally very much, smaller, and perhaps about eight inches may be taken as the average size.

There are 33 different varieties enumerated by the Chinese traders and others skilled in its classification, and it varies in price according to quality from $5 s$. to IOs. the pound. Fashion and custom have caused each variety to have a different market. While the gourmand of the 


\section{Io6 The Commercial Products of the Sea.}

south smacks his lips on the juicy white and black kinds, the less cultivated taste of those at the north is satisfied with the red and more inferior varieties.

It is minced down into a sort of thick soup by the Chinese, who are extremely fond of it-and, indeed, with some reason, as when cooked by a Chinaman who understands the culinary art, the trepang is a capital dish, and is rather a favourite among many of the Europeans at Manila.

This sea-slug, when dried, is an ugly looking, dirty-browncoloured substance, very hard and rigid, until softened by water and a very lengthened process of cookery, after which it becomes soft and mucilaginous. It is found in all the sheltered harbours, where it gropes about the bottom, and feeds upon weeds and mollusca. It is taken at low water upon the shoals and mud-banks, over which the fishermen wade knee-deep in water, dragging their boats after them, and when the feet come in contact with a slug, it is picked up and thrown into the boat. They occasionally search in deeper water, where the fishermen avail themselves of the services of the natives, who are expert in diving and tracing out the slugs.

The bèche-de-mer, or trepang, is very abundant on the coasts of New Caledonia, and constitutes the most important branch of commerce. The annual exports are valued at $£ 4000$. The fishery has been carried on for a long time on a neighbouring island, Erromango, which serves as an entrepôt, where vessels load with this article and sandal-wood, which they carry to Shanghai or Hongkong. The merchants here, however, prefer to ship to Sydney, for which the trepang serves as a return cargo for the vessels which bring merchandise.

Although there is such a great number of varieties of 
this sea-slug, only about five have any great commercial importance, which are as follows, with their nominal value in New Caledonia:-

\begin{tabular}{|c|c|c|c|c|c|}
\hline I. Brown, with & eats & $\cdots$ & $\begin{array}{l}\text { Per ton. } \\
£ 30\end{array}$ & ... & Francs. \\
\hline 2. Large black & $\ldots$ & $\ldots$ & 25 & $\ldots$ & $2 \circ 0$ \\
\hline 3. Small black & ... & ... & 20 & ... & I'30 \\
\hline 4. Red bellies & ... & $\ldots$ & 15 & ... & 1.00 \\
\hline White & $\ldots$ & $\ldots$ & 12 & $\ldots$ & 70 \\
\hline
\end{tabular}

The first quality sells in China often as high as $£ 90$ to $£$ IOO the ton. The prices in the second column per kilogramme are those given in the French Colonial Catologue of the Paris Exhibition, 1878.

FIG. I.
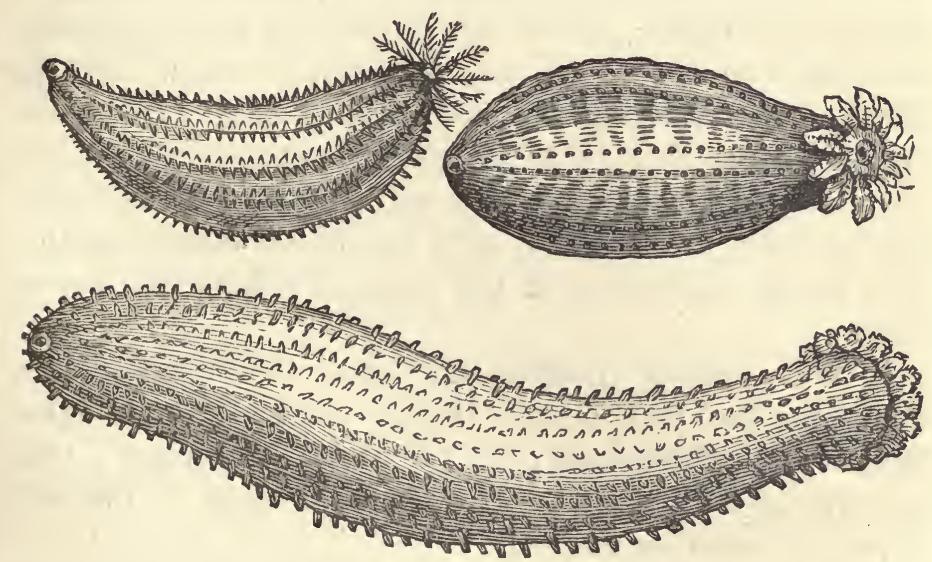

Holothuridæ species.

The preparation of the product is very simple. It is boiled in water for about 20 minutes, and then slit up from one end to the other and dried. This process is carried on in a large shed, with three stages of frames disposed over a good fire to smoke and dry them. As the trepang is very hygrometic, it is indispensable that they should be kept dry- 


\section{Io8 The Commercial Products of the Sea.}

ing until the moment of shipment, in order that they may not imbibe moisture, for then they become flaccid and decay.*

The following detailed account by Captain Andrew Cheyne, who had had much experience in the fishery and preparation, was published some years ago in a volume of my "Technologist" :-

"There are many kinds of bèche-de-mer found on coral reefs in the Pacific Ocean; but only ten of these varieties are marketable in China, each being distinguished by wellknown names. As they vary in price from 6 to 35 Spanish dollars per picul (I $33 \frac{1}{3} \mathrm{lbs}$.), it becomes a matter of great importance to obtain the superior qualities. The slug when cured presents quite a different appearance to what it does when caught; and no person but one well acquainted with the trade would be able to ascertain which were the first quality, by comparing the raw slug with a cured one. Again, the success of a voyage depends greatly on the knowledge possessed by the person in charge of the localities in which the superior sorts are to be found, together with much experience in the mode of fishing and curing them.

"The superior qualities are known by the following names in the Sooloo and Manila markets:-I. Bangkolungan; 2. Keeskeesan; 3. Talepan ; 4. Munang; each presenting a different appearance, and found in different depths of water on the reefs.

"I. Bankolungan, when caught, is from II to I 5 inches in length, of an oval shape, brown on the back, and the belly white and crusted with lime, with a row of teats on each side the belly. It is hard, rigid, and scarcely possesses any power of locomotion. It has, however, the power of expanding and contracting itself at pleasure. This quality

* "Revue Maritime et Coloniale." Paris, March, 1866. 
is found on the inner edge of coral reefs, in from 2 to 10 fathoms water, and on the bottom of coral and sand. It can only be procured by diving.

" 2 . Keeskeesan is from 6 to 12 inches in length, of an oval shape, quite black, and smooth on the back, with a dark-greyish belly, and one row of teats on each side. When contracted, it is similar in shape to a land tortoise. This quality is found in shallow water, on the top of coral reefs, and on a bottom of coral and sand. Bangkolungan and Keeskeesan fetch about the same price; and the latter being the most plentiful and easiest caught, ought of course to be the kind most sought after.

"3. Talepan varies in length from nine inches to two feet, and presents the most remarkable appearance of any of the species of bèche-de-mer. It is found on all parts of the reefs, but chiefly in from two to three fathoms water. It is of a dark-red colour, and narrower in proportion than the before-mentioned kinds. The whole back is covered with large red prickles, which render it easily distinguishable from any of the other kinds. It is much softer than the black, and more difficult to cure.

"4. Munang is of a small size, seldom exceeding eight inches in length, of an oval shape, quite black, and smooth; has no teats or other excrescences, and is found in shallow water on the coral flats, and often among turtle grass near the shore. This is the kind which the American vessels chiefly procure at the Fiji Islands. It is worth from I 5 to 25 dollars per picul in the China market. These four varieties form the superior qualities of the slug, and the following are the middling and inferior sorts :-

" 5. Sapatos China is of a reddish-brown colour, and about the same size as the Munang. It presents a wrinkled surface, and is found adhering to the coral rocks on the 


\section{IO The Commercial Products of the Sea.}

top of the reefs. 6. Lowlowan is of various lengths, black, wrinkled, and narrow. It is found on various parts of the reefs. 7. Balati blanco is about nine inches in length, of an oval shape, and a white-and-orange colour; and may be easily known by its voiding a white adhesive substance, which adheres to the fingers when handled. It is found generally on the inner edge of reefs, and on a sandy bottom. Moonlight nights are the best time for collecting this sort, as they generally bury themselves in the sand during the day. 8. Matan is of the same species and habits as No. 7, and only differs from it in colour, which is grey, brown, and white speckled. 9. Hangenan is generally about a foot in length, of a grey or greenish colour, wrinkled, and is found on the lagoon side of coral reefs. IO. Sapatos grande is about 12 or 15 inches in length, and of a brown-and-white colour,' wrinkled, and very inferior.

"The following remarks on boiling bèche-de-mer are the result of a number of experiments made at different times. Bangkolungan and Keesgeesan will require to be boiled about five minutes or more, if the pot is nearly full; they must be well stirred, and should be taken out when thoroughly heated through, by which time they will feel quite hard and elastic. The cut part of the fish, when properly boiled, should be of a blue-and-amber colour, and feel firm like india-rubber. If the pot is only half full, they will require to boil fully io minutes before the cut part becomes of the blue-and-amber colour. The Talepan and Munang require to be boiled fully io minutes. The Munang dries very quickly; but the Talepan is very difficult to cure, and often requires two boilings before it will dry. The Sapatos China requires to be boiled about I 5 minutes; if properly boiled it will dry very quickly. 
The Balati Blanco and Matan need very little boiling, say three or four minutes if the pot is nearly full. They should be taken out as soon as they shrink and are thoroughly heated through. The Hangenan should be boiled about 20 minutes. This sort must be very carefully handled when raw, as it will break in pieces if held any time in the hand. It appears to me that there are two ways of boiling bèche-de-mer equally good. The first is to take them out when boiled about a minute, or as soon as they shrink and feel hard; the other method is to boil them as before stated; but in boiling either way, the slugs ought, if properly cooked, to dry like a boiled egg immediately on being taken out of the pot. Bèche-de-mer dried in the sun fetches a higher price than that dried over a wood fire. But this method would not answer in curing a ship's cargo, as they take fully 20 days to dry; whereas by smoking them they are well cured in four days.

"Much skill is required in drying bèche-de-mer, as well as in boiling it, as too much heat will cause it to blister, and get porous, like sponge ; whereas, too little heat again will make it spoil, and get putrid within 24 hours after being boiled. There is, likewise, great care and method requisite in conducting the gutting; for if this be not properly attended to, by keeping the fish in warm water, and from exposure to the sun, it will, when raw, soon subside into a blubbery mass, and become putrid in a few hours after being caught."

The first thing to be done on arrival at an island where the slug is plentiful, is to erect a large curing-house on shore, about 90 feet in length, 30 feet in breadth, and the sides about 10 feet in height. These houses are generally built of island materials, and thatched with mats, made by the natives, of cocoa-nut leaves; the thatch must be well put 
on, so as to prevent the rain from penetrating. The sides are likewise covered in with these mats, and a small door should be left in each end. Platforms, or batters, for drying the slug on, are then erected along one side of the house. They should run the whole length, and be about eight feet in breadth; the lower one about breast-high from the ground, and the upper three feet above that. The frames are generally made of cocoa-nut trees, or pandanus, and covered with two or three layers of split bamboo, or reeds, seized close, so as to form a sort of network for the slugs to lay on. Much care and skill is required in the construction of these batters, or platforms, so as to prevent the bèche-de-mer from burning, which it would be liable to, were they not properly fitted. A trench, about six feet in breadth and two feet in depth, is then dug the whole length of the batters for the fires. Tubs are placed at short distances along the side of the trench, filled with salt water, and a good supply of buckets kept in readiness, to prevent the fires from blazing up and burning the fish, or platforms, as well as to regulate the degree of heat necessary for drying the slug.

The process of curing is this:-The bèche-de-mer is first gutted, then boiled in large pots; and, after being well washed in fresh water, carried into the curing-house, in small tubs, or baskets, and emptied on the lower batter, where it is spread out (about five inches thick) to dry. The trench is then filled with firewood, and when the batter is full of trepang, the fires are lighted, and the drying process commences. From this time the fires must be kept constantly going, day and night, with a careful officer and regular watch to attend to it. On the afternoon of the following day the fires are extinguished for a short time, and the slugs shifted to the upper batter, having been first examined, and splints of wood put into those which may 
not be drying properly. When this is done, the lower batter is again filled from the pots, the fires immediately lighted, and the drying process continued as before. The slugs on the lower batter must be turned frequently during the first 12 hours. On the second day (the fires having been extinguished as before) the slugs on the upper batter are shifted close over to one end, to make room for those on the lower batter again; and so on, as before, for the two following days, by which time the first day's produce will be properly cured. It is then taken off the batter, and, after having been carefully examined, and those not dry put up again, the quantity cured is sent on board the vessel, and stowed away in bags. But should the ship be long in procuring a cargo, it will require to be dried over again every three months, in the sun, on platforms erected over the deck, as it soon gets damp, unless when packed in airtight casks.

If the bèche-de-mer is plentiful, and the natives bring it daily in large quantities, 40 men will be requisite to perform the work of a house of the above size; and the pots will want two hands to attend them. These curing-houses consume a large quantity of firewood daily. When bèchede-mer is cured and stowed away, great care should be taken to prevent it from getting wet, as one damp slug will speedily spoil a whole bag.

The bèche-de-mer fisheries at the Fiji Islands have been extended of late years, particularly upon the Mattuata coast, situated upon the north side of Vanna Levu. The increase of value of export upon this head has been large, and, provided the exertions used to keep the petty chiefs from quarrelling are successful, will no doubt augment. The product is sold there at about $36 s$. per picul. The prices fluctuate very much, being sometimes as high as $40 s$. 
I 4 The Commercial Products of the Sea.

per picul and as low as $24 \mathrm{~s}$. during consecutive months. It is shipped to Sydney, and thence to China.

The exports were in-

\begin{tabular}{rrrrrrr} 
& & \multicolumn{3}{c}{ Piculs. } & & \multicolumn{2}{r}{ Value. } \\
1865 & $\ldots$ & $\ldots$ & 500 & $\ldots$ & $\ldots$ & $£ 1200$ \\
1866 & $\ldots$ & $\ldots$ & 300 & $\ldots$ & $\ldots$ & 600 \\
1867 & $\ldots$ & $\ldots$ & 880 & $\ldots$ &. & 1600
\end{tabular}

From Tahiti there were shipped, in 1874, 5346 lbs., valued at $£ 58$.

The following are some of the names, classifications, and prices given to specimens shown in the British Museum, London, but the prices are old quotations :-

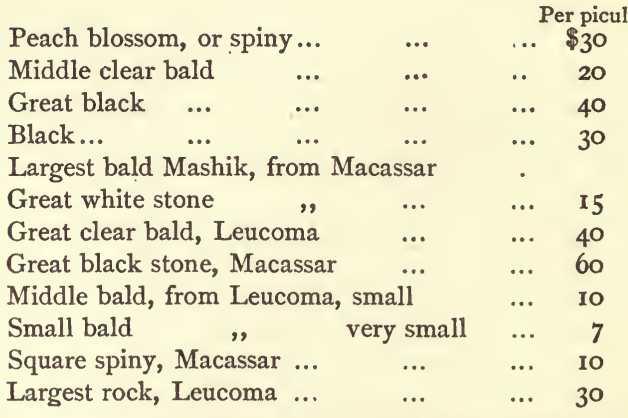

Trepang is very abundant around Tahiti, Moua, and the Windward Islands. The ordinary price at Tahiti is about $£ 40$ per ton. A single house sometimes ships I 50 tons to California, to be thence sent on to China. The imports of bèche-de-mer into China in foreign vessels were stated to be as follows :-

\begin{tabular}{|c|c|c|c|c|c|}
\hline I 868 & $\ldots$ & $\ldots$ & $\ldots$ & $\ldots$ & $\begin{array}{l}\text { Piculs of } x 33 \\
18,407 \frac{1}{2}\end{array}$ \\
\hline r 869 & $\ldots$ & $\ldots$ & $\ldots$ & $\ldots$ & 15,579 \\
\hline 1870 & $\ldots$ & $\ldots$ & $\ldots$ & $\ldots$ & I 5,447 \\
\hline 1871 & $\ldots$ & $\ldots$ & $\ldots$ & $\ldots$ & I $1,33^{8}$ \\
\hline 1872 & $\ldots$ & $\ldots$ & $\ldots$ & $\ldots$ & I 7,953 \\
\hline
\end{tabular}

Taking one year, $187 \mathrm{I}$, we find the following imports of 


$$
\text { The Trepang Fishery. }
$$

trepang were received at different ports in China in Chinese vessels :-

$\begin{array}{lllllr}\text { Chukiang } & \ldots & \ldots & \ldots & \ldots & \text { 1008 } \\ \text { Swatow } & \ldots & \ldots & \ldots & \ldots & 404 \\ \text { Kiukiang } & \ldots & \ldots & \ldots & \ldots & \text { 144 } \\ \text { Takow } & \ldots & \ldots & \ldots & \ldots & \text { I8 } \\ \text { Tamsui } & \ldots & \ldots & \ldots & \ldots & 34 \\ \text { Ningpo } & \ldots & \ldots & \ldots & \ldots & \text { I I34 } \\ & & & & & 2742\end{array}$

And Shanghai and Foochow receive together about 6000 to 7000 piculs.

It is difficult to form an estimate as to the amount of trepang annually exported from the North Australian coast. From 30 to 40 prahus, varying from 20 to 70 tons burthen, are employed in the fishery, the crews amounting to about 1200 men. They receive no wages, but are entitled to a certain portion of the profits of the voyage, the system being somewhat similar to that adopted in whale-ships. The provisions and stores required for the voyage are advanced by Chinese or Dutch merchants at Macassar, who thus acquire a right to the entire proceeds at a certain price which has previously been fixed upon, and which is invariably much below the current value. Taking the average amount of trepang obtained by each prahu at 20 tons, this will give about 600 tons as the quantity annually exported from the coast. The value at Macassar is 70 rupees, or somewhat less than $£ 7$ sterling, for the picul of $\mathrm{I} 33 \mathrm{lbs}$. avoirdupois. The price to the consumer in China is enhanced to the amount of about one-third. 
1 I6 The Commercial Products of the Sea.

CHAPTER $\mathrm{X}$.

CEPHALOPODS, ETC., AS FOOD.

Dried cuttle-fish as food-Consumption of octopods and polypi in the countries bordering on the Mediterranean-Prices in Tunis-Mode of capture and preparation-Squid used for bait by the North American fishermenCuttle-fish bone and sepia-Large consumption of dried cuttle-fish in China-Species of Echinus eaten-Palolo viridis, a kind of sea-worm, edible; fishery for, in the Pacific.

THE flesh of the large cephalopodous animals was esteemed as a delicacy by the ancients. Most of the eastern natives, and those of the Polynesian Islands, partake of it and relish it as food. They are exposed for sale, dried, in the bazaars or markets throughout India, and in the Food Collection arranged at the East End Museum, Bethnal Green, dried cuttle-fish may be seen among the articles of Chinese, Japanese, and Siamese food. In Chili the flesh is also considered a delicacy, and in Barbados the bastard cuttle-fish or calmar (Loligo sagittata, Lam.) is used as an article of food by the lower classes. But from my small experience of this kind of diet, notwithstanding the assertion of the learned Bacon in his "Experiment Solitary touching Cuttle Ink," that the cuttle is accounted as a delicate meat, and is much in request, I should say that it 
is as indigestible and innutritious as it is certainly tough and uninviting.

Cephalopods are eaten at the present day on many parts of the Mediterranean coast. Mr. Vice-Consul Green, in a recent report, furnishes some novel and interesting particulars as to the fishing and trade in cephalopods in the Tunis waters. Octopodia and polypi are the trade names under which these cephalopods are known in the Levant and Greek markets, where they are solely imported for consumption during Lent, the orthodox Church not including them in the prohibition against the use of fish in seasons of religious abstinence. They prefer rocky shallows, and visit those waters, coming from the open sea, in the months of January, February, and March. A considerable number of octopodia, however, remain permanently near the shores; but it has been observed that when their fry, locally called "muschi," are numerous from the month of June to August, the fishing of the coming season is sure to be abundant, whilst the reverse is the case if they appear in numbers in November and December. In a good season the several villages on the island of Karkenah supply about 3000 cwts., and the Jubah waters a third part of this quantity. In an average year the yield will be under $2000 \mathrm{cwts}$., and in one of scarcity 1000 cwts. On the shores from the village of Luesa to that of Chenies, in the Gulf of Khabs, the natives collect from four to five cwts. of cuttle-fish a day during the season; but this supply generally serves for the consumption of the regency. The remaining coast and islands may be calculated to furnish a minimum of 650 to $700 \mathrm{cwts}$. of dried molluscs.

The Tunisian Government claims a third of all the polypi fished upon its coast. The selling price varies con- 


\section{8 The Commercial Products of the Sea.}

siderably, according to the size, supply, and demand, but at Sfax a pair of them may cost, as circumstances rule, from $6 d$. to Is. $3 d$. ; however, the preparatory maceration, by beating on a stone slab or rock, required before drying entails a small additional expense, and brings the extremes of low and high prices to $25 \mathrm{~s}$. or $50 \mathrm{~s}$. per cwt. To the cost price must be added an export duty of $5 s$. I $d$., and the purchaser ought to be careful to receive his merchandise from the seller during dry weather, as a damp day will add from four to five per cent. to the weight of every cwt.

From two to three public sales of dried polypi take place in a season on the island of Karkenah; these are regulated according to the abundance of the fish. The average price of the last six years has been-during the first sale, from $45 \mathrm{~s}$. to $50 \mathrm{~s}$. per cwt.; second sale, $35 \mathrm{~s}$. to 45 s. ; third sale, 25 s. to 30 s. A few first parcels, in order to secure an early market, have, however, occasionally been sold for $£ 5$ the cwt.

Polypi have hitherto been prepared for exportation by simply salting and drying them, but it is now proposed to carry out on a large scale an experiment, which appears to have proved successful, of preserving them either in oil or brine, after subjecting them to a preliminary scouring and boiling process.

Malta receives the largest share of the Tunisian polypi, but they are only sent to that island for ultimate transmission to Greece and other parts of the Levant. Portugal is one of the few countries that competes with Tunis in supplying the Greek markets with polypi. In Greece they are either sold, after being pickled, at from $£ \mathrm{I} 2 \mathrm{I} \sigma s$. to $£ 159 \mathrm{~s}$. the cantar of $176 \mathrm{lbs}$., or in their original dried state at from $£ 12$ to $£ I 4$, but these prices fluctuate ac- 
cording to the favourable or unfavourable results of the season's fishing.

On the first arrival of the octopodia in the shallows they keep in masses or shoals, but speedily separate in search of shelter among the rocks near the beach, covered by only one or two feet of water, and in the stony localities prepared for them by the fishermen in order to frustrate the depositing of their spawn. Polypi are taken in deep water by means of earthen jars strung together and lowered to the bottom of the sea, where they are allowed to remain for a certain number of hours, and in which the animals introduce themselves. Frequently from 8 to Io polypi are taken from every jar at each visit of the fishermen. In less deep water earthenware drain-pipes are placed side by side, for distances frequently exceeding half a mile in length, and in these also they enter and are taken by the fishermen. As they are attracted by white and all smooth and bright substances, the natives deck places in the creeks and hollows in the rocks with white rocks and shells, over which the polypi spread themselves, and are caught from four up to eight at a time. But the most successful manner of securing them is pursued by the inhabitants of Karkenah, who form long lanes and labyrinths in the shallows by planting the butt-ends of palm branches at short distances from each other, and these constructions extend over spaces of two or more miles. On the ebb of the tide (the fall is here about Io feet) the octopodia are found in the pools inside the enclosures, and are easily collected by the fishermen, who string them in bunches of 50 each, and from 8 to 10 of these bunches, called "risina," are secured daily during the season by every boat's crew of four men.

The squids form an important element in the North 
American fisheries. The common Loligo is the favourite food of the cod, and is therefore itself fished for bait. One-half of all the cod taken on the banks of Newfoundland are said to be caught by it. When the vast shoals of this mollusc approach the coast, hundreds of vessels are ready to capture them, forming an extensive cuttle-fishery, engaging 500 sail of French, English, and American ships. During violent gales of wind, hundreds of tons of them are often thrown up together in beds on the flat beaches, the decay of which spreads an intolerable effluvium around. They must themselves be consumed in enormous numbers, for it has been estimated that a single squid will lay in one season 40,000 eggs.

The cuttle-fish are frequently left stranded on the beaches, and are also caught by fishermen, who obtain two valuable products from them-the so-called calcareous bone (which is much used by chemists, when pulverized and tinted, and sold as coral tooth-powder), and the ink-bag, which forms the sepia colour of artists. On the coasts of Brittany and La Vendée, the flesh of this polypus is eaten and appreciated, but on many other coasts it is disdained. Much depends, however, on its culinary preparation, which is somewhat difficult.

Dried cuttle-fish form a large article of export from Japan to China. They are called susume, and are brought chiefly from Esasi, Matsmai, and the west coast of Yesso, Fugaro, and Yetzidzen, generally during February and October, and the prices paid vary from 14 to $I 6 \frac{1}{2}$ dollars. Small quantities brought to Hakodate from Sado Island, situated near the west coast of Niphon, are said to be of very good quality.

To show the extent of the Chinese trade, it may be stated that in the quarter ending June, I 872 , the imports into three of the Chinese ports were as follows:- 


$\begin{array}{lllllr} & & & & & \text { Picals. } \\ \text { Kiukiang } & \ldots & \ldots & \ldots & \ldots & 869 \\ \text { Shanghai } & \ldots & \ldots & \ldots & \ldots & 1564 \\ \text { Ningpo } & \ldots & \ldots & \ldots & \ldots & 1745 \\ & & & & & \frac{4198}{}\end{array}$

-equal to $5222 \mathrm{cwt}$.

What is commonly termed cuttle-fish bone is frequently found floating in the Mediterranean Sea, and in much greater quantity on the shores of Australia. It is of an oblong oval shape, from 3 to Io inches long, and its breadth is about one-third of its length; hard upon its upper surface and edges, but soft on its lower side, both surfaces being convex. Its specific gravity is about '935. Its composition, though calcareous, is quite different from bone, being about 83 per cent. of carbonate of calcium, with some magnesia and common salt, and but little animal matter. The structure is quite peculiar; a fresh fracture, when examined, shows the layers of the calcium salt, supported by pillars of the same material, arranged in regular rows, likened by Wood the naturalist to an imitation Giant's Causeway. It furnishes cage-birds with tiny grindstones, whereon to whet their bills, and levigated and dried it forms the basis of some dentrifices.

When the ovaries of some of the species of sea-eggs or sea-urchins are fully developed-the Echinus edulis, for instance-they are collected as food. The late Sir Robert Schomburgk, in his "History of Barbados," mentions that they are eaten there.

The Echinus albus is eaten by the Chilians and others. It is of a globular form, and about three inches in diameter ; the shell and spines are white, but the interior substance is yellowish and of an excellent taste.

Palolo.-Another curious food product obtained in the Pacific, which is esteemed as highly as whitebait in Eng- 
I 22 The Commercial Products of the Sea.

land, is the Palolo viridis, Gray, a small species of seaworm, a genus of annelides. The Rev. J. B. Starr, of the London Missionary Society, has given the best description of it, as follows :-

FIG. 2.

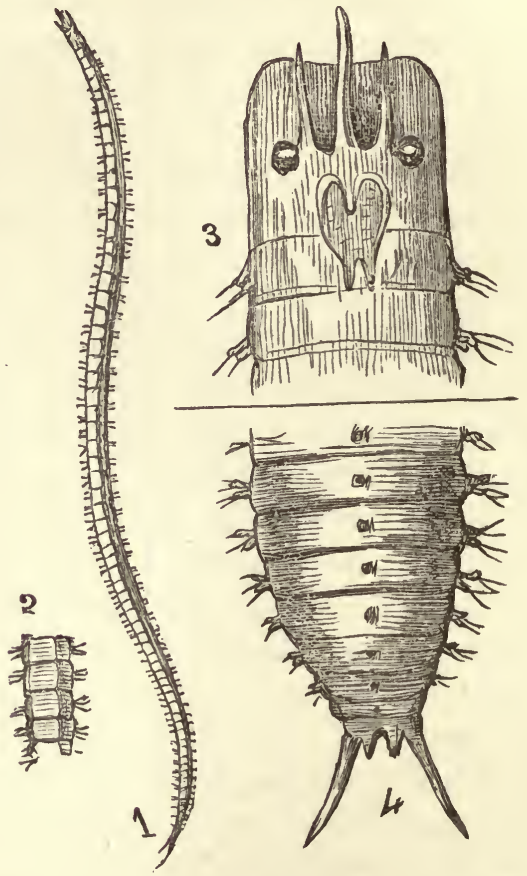

I. Palolo viridis, natural size. 2. Portion of body, slightly magnified. 3 . Magnified figure of head. 4. Ditto of posterior extremity. (Gray.)

"The palolo is the native name for a species of seaworm which is found in some parts of Samoa (the Navigator Islands) in the South Pacific Ocean. They come regularly in the months of October and November, during portions of two days in each month, viz., the day before 
and the day on which the moon is in her last quarter. They appear in much greater numbers on the second than on the first day of their rising, and are only observed for two or three hours in the early part of each morning of their appearance. At the first dawn of day they may be felt by the hand swimming on the surface of the water ; and as the day advances their numbers increase, so that by the time the sun has risen, thousands may be observed in a very small space, sporting merrily during their short visit to the surface of the ocean. On the second day they appear at the same time and in a similar manner, but in such countless myriads that the surface of the ocean is covered with them for a considerable extent. On each day, after sporting for an hour or two, they disappear until the next season, and not one is ever observed during the intervening time. Sometimes, when plentiful at one island in one month, scarcely any are observed the next; but they always appear with great regularity at the times mentioned, and these are the only times at which they are observed throughout the whole year. They are found only in certain parts of the islands, generally near the openings of the reefs on portions of the coast on which much fresh water is found; but this is not always the case.

"In size they may be compared to a very fine straw, and are of various colours and lengths, green, brown, white, and speckled, and in appearance and mode of swimming resemble very small snakes. They are exceedingly brittle, and if broken into many pieces, each swims off as though it were an entire worm. No particular direction appeared to be taken by them in swimming. I observed carefully to see whether they came from seaweed or rose from the reef, and feel assured they come from the latter place. The natives are exceedingly fond of them, and calculate with 


\section{24 The Commercial Products of the Sea.}

great exactness the time of their appearance, which is looked forward to with great interest. The worms are caught in small baskets, beautifully made, and when taken on shore are tied up in leaves in small bundles, and baked. Great quantities are eaten undressed, but either dressed or undressed they are esteemed a great delicacy. Such is the desire to eat 'palolo' by all classes, that immediately the fishing parties reach the shore, messengers are despatched in all directions with large quantities to parts of the island on which none appear."

The great antiquity of the name for this worm amongst the South Sea Islanders (Balolo and Palolo) is attested by the fact that the parts of the year most nearly corresponding with our months of October and November, are respectively named "Vula i Balolo lailai" (little), and "Vula i Balolo leva" (large); the latter, as its name implies, is distinguished by the appearance of the "balolo" in such vast numbers that it is collected by the natives as a dainty article of food, and is so much prized that formal presents of it are frequently sent considerable distances into the interior, from certain chiefs resident on the coast, to others whose dominions do not happen to be favoured by the annual visit of the "balolo."

Dr. Seemann, in his "Mission to Viti," gives us the following extract of a letter from a lady in Fiji to her friends in England:- "In November we all went for a few days to Wakaya, about io miles east-north-east from Ovalau, in order to see the balolos, which rise out of the reefs just before daylight, at first in small numbers, but about sunrise in such masses that the sea looks more solid than liquid. As they were to appear on the morning of the $25^{\text {th }}$, we retired to rest at an early hour the night before, and rose with the moon about one o'clock in the 
morning. An hour's pull in the whaleboat brought us to the very spot to which they were to come. We found several natives already collected there in boats and canoes, all anxiously looking out who should get the first 'balolo.' This they discovered by sitting with their hands in the water as the canoe was gently paddled about. Presently there was great shouting-nets were put out, and the excitement commenced. At first our nets did very well ; but soon the balolos became too numerous for them to be of any use, and they were caught by the hands and thrown into the baskets with which the boats were filled. We placed a white handkerchief four inches below the surface of the water, but the little creatures were so thick above it that it was quite invisible. At first I could not make up my mind to touch them, but seeing every one else doing so, I summoned up all my courage, plunged in my hands, and grasped a goodish number, of which however I got rid as quickly as possible. The little slimy things twist round the hand in half a second. They are of course perfectly harmless, swim very fast, and the longer ones have sometimes five or six coils in the body. When at the thickest, they are all entangled one in another, presenting a very curious appearance, as they are of various shades of green, brown, and white. As the sun gains power, they disappear, and about eight or nine o'clock you can scarcely find one. It is always in November they come in such masses, just after the last quarter of the moon, and they rise with the tide. As soon as the natives have gathered all they can, they make fires and ovens to cook them. Small quantities of ' balolo' are tied up in bread-fruit leaves, and have to lie in the oven from 12 to 18 hours. When all is cooked, the natives expect a heavy shower of rain, as they say to put 
I 26 The Commercial Products of the Sea.

out the fires of their ovens. Should there be no rain, a bad yam season is expected."

Many of the European residents in the Fijis eat the "balolo," and look on it as quite a periodical relish. It also makes its appearance in the New Hebrides, in Tonga, and in the Samoan or Navigator Islands identically with its advent in Fiji. 


\section{( 127$)$}

\section{CHAPTER XI.}

\section{MISCELLANEOUS FISHERIES.}

The capelin fishery of Newfoundland-Chiefly used as bait for cod-Some shipped pickled and dried-The halibut fishery on the American coastThe sword-fish eaten as food-Fishing for turbots, soles, and other flat fish -Quantity sold annually in Billingsgate-Fish in India.

The Capelin Fishery.-The capelin (Mallotus arcticus; M. villosus, Cuv.) is peculiar to Newfoundland and Labrador. It is a very delicate fish, resembling a smelt. Its visits are during August and September, for the purpose of spawning on beaches. At times they are so numerous as to darken the sea for miles, while the cod feed on them with the utmost voracity. We only know them in Europe in the dried state, some quantity being imported from Newfoundland.

As an article of bait for cod and other fish of that class, the capelin is of much importance; whenever abundant, the cod fishing is excellent. Like the common smelt, it possesses the cucumber smell, but differs from the smelt in never entering fresh-water streams.

This delicious fish is now only locally sought for bait and manure, but a very small quantity are cured. This may hereafter become a great source of wealth, when we con- 


\section{I28 The Commercial Products of the Sea.}

sider how large a trade is carried on in sardines and anchovies. If they were merely pickled and dried, a simple operation which could be performed by children, they would be worth at least $4 s$. a barrel; and 1,000,000 barrels would find a market if introduced into fish-eating countries, and not sensibly lessen the quantity which every summer swarms in every bay and creek of the island of Newfoundland and the Labrador coast.

The Halibut (Hippoglossus vulgaris, Cuv.).-The halibut abounds in the waters of the Atlantic coast from Newfoundland to Cape Hatteras. From some ports of Nova Scotia a considerable trade in halibut is carried on with the United States. On parts of the coast the fish is so abundant, and of such large size, that the localities are avoided by those engaged in cod fishing, as a boat or small vessel becomes soon heavily laden. This fish sometimes attains the weight of 400 to 500 lbs. The flesh is somewhat coarse and dry, but is much esteemed by many. It is lightly salted and smoked. The fins and flaps are delicacies, if the fish is in good condition. The halibut is also cut into slices and pickled in barrels, in which state it sells at half the price of the best herrings.

The fishing for the halibut is very important, and 5000 to 6000 barrels are taken in the British Provinces by Americans, few of the native settlers embarking in it. The fish is somewhat different from the European fish of the same name.

Sword-fish.-The flesh of the Tetrapturus Australis is an excellent article of food, much resembling that of the true sword-fish or "pesce spada" (Xiphias gladius) of the Mediterranean. Its flesh is much esteemed there as an article of food. The sword-fish is common in the Bosphorus, and measures Io to 12 feet, and of proportionate girth. The 
flesh, which is of a dull red colour, is very palatable, and a sword-fish steak makes an excellent substitute for a salmon cutlet. A sword-fish was shown at Boston, U.S., some years ago, which weighed over I000 lbs., and measured, including the sword, I4 feet.

The fishermen of Sables d'Olonne, France, dry and salt the flesh of Squalus caniculata, and of another species, the dog-fish ( $S$. galeus), for winter use.

Turbot, Soles, etc.-The British trawl vessels catch their fish on the vast submarine plateau extending from Flamborough Head to the south of Orfordness on the English coast, and from the Long Fisher Bank, north of Heligoland, to Ter Schelling, on the Dutch coast.

Soles fourteen years ago cost $2 d$. to $2 \frac{1}{2} d$. per $1 \mathrm{~b}$. ; now they are worth $8 d$. to I $s .2 d$. per $1 \mathrm{~b}$. Large soles are difficult to get at all. Small soles go by the name of "tongues;" the smallest are "cat's tongues." "Slips" are $9 \frac{1}{2}$ to to inches in length. A fair-sized sole would be about 12 inches. The legal sizes for the sale of fish in France limit soles and turbot to four inches.

Sole fishing is a trade carried on most extensively at various parts of the English coast, but more particularly at the Great Silver Pitts, situated betwixt the Dogger and Wellbank, east from the Humber river. Sole fishing is conducted upon exactly the same principle as oyster dredging. The vessel sails easily along at the rate of about two knots per hour, pulling the dredge after her; and as the trawler's dredge or net is fitted with inside pockets, when once the fish are fairly entered into the net, they cannot again easily get out. The depths and bottom about the middle of the Firth of Forth are similar to those about the Great Silver Pitts, and as soles are frequently caught by fishermen on their lines, the supposition is that were dredges used in 


\section{I30 The Commercial Products of the Sea.}

25 and 30 fathoms' water in the Firth, soles might also be found there lying in clusters.

On that part of the northern coast of Ireland connected with Lough Foyle, turbot fishing is carried on from March to November. Turbot average to the fishermen $3 s$. to $4 s$. per dozen, and there are about 12 dozen of turbot sent weekly from Moville to Liverpool and Glasgow. A considerable quantity of soles and plaice is also shipped from the trawlers.

One hundred millions (or about I2,000 tons in weight) of soles are said to be sold annually in Billingsgate.

Nearly every fish that swims, either in salt or fresh water, is greedily eaten by the natives in India. Sharks especially are much valued, and said to be very palatable and nutritious. The fishery for these is described in another chapter. In the bazaars of Madras it would be possible to obtain some 200 or 300 kinds of dried fish, including different preparations of the same species. In curing fish, salt, owing to its high price, is used as sparingly as possible, and hence, as a rule, the dried fish of the bazaar has anything but a pleasant odour. In some quarters saline earth is used instead of salt, as being cheaper; but fish cured in this manner is said to have an unpleasant flavour, and to be apt, when continuously used, to bring on itch. The fish most in repute for European tables in Madras are the seer (Cybium Commersonii), the pomfrets (Stromateus niger and S. argenteus), and mullets. The seer is sold in cutlets, like salmon in Europe, and is in some respects perhaps superior to salmon, more especially as regards digestibility. 


\section{( I3I )}

\section{CHAPTER XII.}

OYSTERS AND OTHER EDIBLE MOLLUSCA.

Britain long celebrated for oysters-Large consumption and great value of those consumed in England-Continually advancing prices-The Jersey fishery-The French oyster fishery-Oyster consumption in Paris-Ostreiculture on the French coast-American oyster fishery-The New York trade-Oysters in Australia-Clams and other edible molluscs.

THE geographical distribution of the oyster is extensive. Large quantities are found on the American coasts and at the Antipodes. On the coast of Africa it is also plentifully sprinkled.

In antiquity Britain was so celebrated for oysters, that they were sent to Rome ; a fact attested by more than one of the Roman poets. The epicures of that city had their layers or stews for oysters, as we have at present in the open sea. According to Pliny, the oyster reservoirs were first made by Sergius Orata, not for the gratification of his own palate, but as a most lucrative speculation by which he realized large profits. The ancients ate oysters as we do, either raw or roasted ; but they had also a way of stewing them with mallows and docks, and sometimes with fish. There is a curious account of the treatment of oysters in. Sprat's "History of the Royal Society," an abstract of 


\section{I32 The Commercial Products of the Sea.}

which may be found in Pennant's "British Zoology." About I776, the oysters of Colchester and Rochester were the most famous; and a great part of the inhabitants of the latter place were concerned in or supported by this fishery, which was conducted by a company of free dredgers, established by prescription, but subject to the Corporation.

It is from September to April that oysters are in most request, and during this interval it is computed there are

FIG. 3.

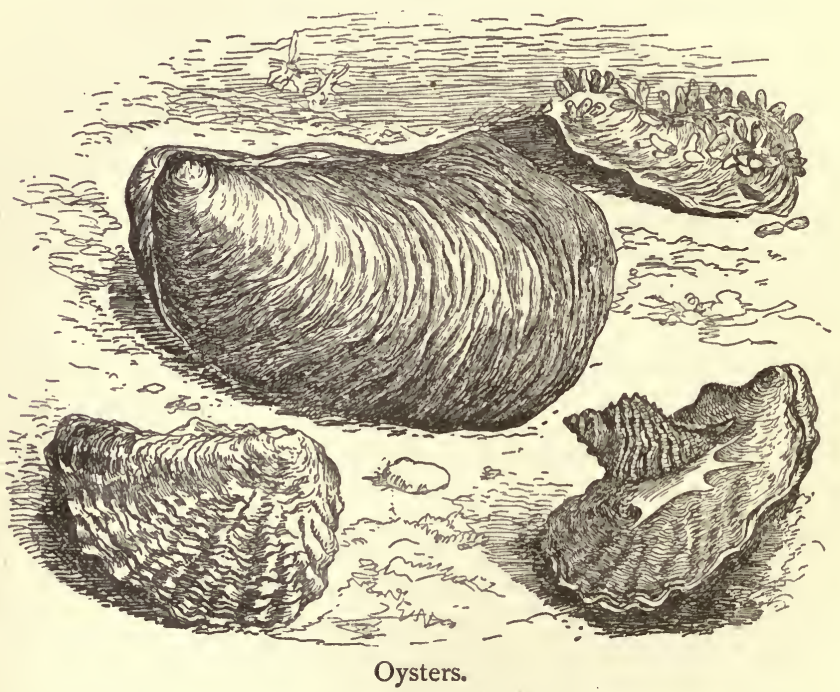

$800,000,000$ of oysters consumed in London alone, and quite as many, if not more, in the provinces. We pay between $£ 4,000,000$ and $£ 5,000,000$ a year for oysters, and there is no doubt double the quantity would find ready consumption if they were obtainable at a reasonable price. During the last ten years the price of "natives" has in"creased from two guineas to ten guineas a bushel. 
The English native oyster of the coasts of Kent and Essex is distinguished from all others:- - . By its peculiar flavour and delicacy. 2. By the colour of its lobes and mantle, which are of a clear green hue, due to the marine plants on which it feeds. 3. By its thin and translucid shell of a brilliant pearly interior, unlike the common oyster which has a large calcareous centre, indicating an inferior quality.

The English native oyster contains iron and alkaline iodides, which renders this mollusc sweet and wholesome, and nourishing food.

Now that the genuine Whitstable oyster fetches $3 s .6 d$. the dozen, and is likely to cost $4 \mathrm{~s}$., if not more, soonwith oysters, in a word, at threepence halfpenny each, and threatening to rise to fourpence-anything that affects, or tends to affect, the price of this delicious bivalve cannot but be matter of almost universal interest. It is certainly cause for great regret that the supply of the best kind of oysters should have fallen so short as it has done of late years. The oyster is not a luxury which only very rich people can expect to command, but it ought to be within the reach of all persons of moderate means. It is essentially the most popular, as well as palatable, of delicacies. It is not many years since the best "natives" from Whitstable and Colchester were only sixpence a dozen in a West-End establishment, and "seconds" but two-thirds of that sum; and then the City clerk, emerging hungry from the theatre, could appease his appetite with oysters and draught stout, secure from any suspicion of undue extravagance. Those golden days unfortunately have fled, and, unless active and practical steps be taken to replenish our oyster beds, they can never be expected to return.

The oyster is not, strictly speaking, a mollusc of the sea. 


\section{I34 The Commercial Products of the Sea.}

It can only live and breed in certain shallow estuaries, and even in these it only thrives within particular limits. If we overfish our estuaries we depopulate them, and we have systematically over-dredged our oyster beds. Thus we are now reaping the inevitable result of extravagance and waste. We must cultivate the oyster, or else rest content to see it become still scarcer, or even extinct. No third course is possible. Oyster culture in England is still in its infancy, but it is satisfactory to know that steps are being taken to improve our knowledge of the subject.

The oyster fishing of Arklow, on the east coast of Ireland, is a large and constant source of employment to the fishermen. The oysters are carried in boats to Beaumaris, in Anglesey, where they are laid on banks and raised when required for the Liverpool market.

Oysters continue to be scarce and dear in England. In former years some hundreds of boats might be seen in Goree harbour, Jersey, engaged in the fishery; now, scarcely a dozen boats can pay their way by dredging. The fishing is most active from February to May.

During the spring of 1850 the number of Jersey boats employed in the fishery was 70, manned by 350 men; of English boats, I 19, manned by 623 men-a total of 189 boats, 4018 tons, 983 men. The quantity of oysters caught was 105,000 tubs, which fetched 35 . a tub-or $£ 15,300$ ! In the autumn of the same year there were 40 Jersey boats, manned by 200 men; 40 English boats, 220 men. These 80 boats caught 19,200 tubs, which sold at $2 s .6 d$. per tub, or $£ 2400$; the total produce of the oysters dredged in the spring and autumn of 1850 being thus $£ \mathrm{I} 7,700$.

In Falmouth harbour there are from 200 to 300 boats employed in the oyster fishery. The price has risen from $2 s$. to I $8 s$. per bushel. 
The conventional ring-gauge of oysters is two and a half inches in diameter, and this, it is thought, might be reduced to two inches.

Some 36,000 bushels of oysters have been taken to the coast of Kent to lay down in beds for the London market, and large quantities are bought by French and other merchants, the French giving the highest price.

The French Oyster Fishery.-To show the importance of the French oyster fishery, it may be stated that more than 30 years ago the value of the oysters taken at the two ports of Granville and Cancale realized £22,000. At Granville I05 boats, employing 760 men, took I $8,750,000$ oysters, and at Cancale 187 boats, with 1083 men, took only $8,000,000$ oysters. The Granville oysters then sold at I9 francs 62 cents the 1000 ; Cancale oysters at 2 I francs.

In a report submitted to the Emperor Napoleon by M. Coste, he showed that the production of oysters on the plan recommended by him had taken such a prodigious development, that in the Ile de Ré alone more than 3000 men, who had come from the interior, had established I 500 parks, which produced annually about 371,000,000 oysters, of the value of from $6,000,000$ francs to $8,000,000$ francs.

To show the consumption of Paris, and the great increase of price, the following figures may be given :-

Consumption.

\begin{tabular}{|c|c|c|c|c|c|}
\hline & & Consumption. & & & $\begin{array}{l}\text { ce per } 1 \\
\text { Francs. }\end{array}$ \\
\hline 1804 & $\ldots$ & I $7,200,000$ & $\ldots$ & $\ldots$ & 一 \\
\hline 846 & $\ldots$ & $47,400,000$ & $\ldots$ & $\ldots$ & $3 \cdot 3^{8}$ \\
\hline $852+2$ & $\ldots$ & $77,900,000$ & $\ldots$ & $\ldots$ & $2 \cdot 27$ \\
\hline $\mathbf{T}$ & $\ldots$ & $57,600,000$ & $\ldots$ & $\ldots$ & $3 \cdot 5^{8}$ \\
\hline 6 & $\ldots$ & $26,500,000$ & $\ldots$ & $\ldots$ & $7 \cdot 20$ \\
\hline
\end{tabular}

The price has since advanced to over I 2 francs the IOO, and the effect has been to stimulate the development of ostreiculture. 


\section{I36 The Commercial Products of the Sea.}

The value of the oysters sold in France in 1872 was $£ 520,000$, and in $1873, £ 600,000$. The ports of Granville, Cancale, and L'Orient produced nearly I 3,000,000 oysters, about 4,500,000 more than in the previous year. Ostreiculture, thanks to the care and wise regulations of the Government, is making rapid progress, both to the benefit of the fishermen and the public. In the quarter of $\mathrm{La}$ Teste, where this industry is extensively carried on, 42,342,250 oysters were obtained, being $17,000,000$ more than in the previous year.

As there is nothing new under the sun, it would appear that artificial oyster-culture is no exception, for in the days of the Stuarts many Star Chamber edicts were issued prohibiting the "exportation beyond the seas" of "oyster faggots," i.e., fascines with young oysters attached; and at another time, in those halcyon days when Whitstable oysters rose from $8 d$. to $6 s$. the bushel, "water measure," their exportation was prohibited, subject to dire pains and penalties. It is strange that the French should learn oyster culture from us, and that we should be beholden to them for what we know about the artificial reproduction of the oyster, notwithstanding the fact that we abound in aquaria paying remunerative dividends.

The French have been more zealous and energetic in oyster culture than we have. At Arcachon, in the centre of a basin exposed only during low water, is a bank called Lahellon, of a surface of about 100 acres, forming the model oyster ground, which is only above water for 25 minutes at every low tide. The oyster bed proper covers only Io acres, to which, however, have been added, as annexations and depôts, about 60 acres of neighbouring banks. On this small space, where the first oysters were planted in 1860 , the enormous oyster population has been 
generated which now covers it, and at some future day will be a source of great wealth.

The first deposit made consisted of 500,000 oysters, and near them I0,000 large hollow earthen tubes were so placed and piled up as to afford a desirable stoppingplace for the young vagabond oysters, the birth of which was expected. Notwithstanding partial failures, unavoidable in all such totally new enterprises, the park of Lahellon, with its appendages, was estimated to have produced, in $1868,50,000,000$ oysters, which is much more than the rest of the bay contained in its 40,000 acres' surface.

It is reckoned that the net increase of the receipts from oysters alone in France is rather over $£ 300,000$ a year. All down the coast of the Bay of Biscay, from Brest to the Gironde, the shores are studded with artificial beds belongging to private individuals, but regularly and rigidly inspected by Government. The population of the islands' of Ré and Oleron in particular are entirely supported by the oyster beds.

Auray in Brittany is, next to Arcachon, the seat of the most important of all French oyster fisheries. There is one establishment in the Auray district-that of M. d'Argy, at Le Breneguy, near Locmariaquer-which comprises about 100 acres in a single enclosure, private property, and about $\mathrm{I} 2$ hectares outside, in addition, between the enclosure and the sea. The IOO acres now forming this great oyster-pond were in 1864 part of a farm belonging to M. d'Argy, and divided in the usual way into fields. In that year the sea broke in, and submerged it, causing, as it was thought at the time, great destruction of property. The proprietor, however, eventually determined some time ago to form it into an oyster-tank, and, by means of sub- 


\section{I38 The Commercial Products of the Sea.}

stantial embankments erected at great cost, has succeeded most completely in doing so. In I $876 \mathrm{M}$. d'Argy laid down $6,000,000$ oysters, $3,500,000$ being of the five-centimetre size. These have grown well, and the large ones were also in good condition; indeed, so satisfactory have been his efforts that he has been enabled to contract for the present supply of $1,000,000$ marketable oysters to London and the same to Paris, while the quantity despatched to each place will shortly be increased to $2,000,000$.

The official value of the produce of the principal oyster fisheries in France in 1873 was given as follows :-

\begin{tabular}{|c|c|c|c|c|}
\hline $\begin{array}{l}\text { Quarters. } \\
\text { Sables d'Olonne }\end{array}$ & $\ldots$ & $\ldots$ & $\ldots$ & $\begin{array}{l}\text { Francs. } \\
60,200\end{array}$ \\
\hline Noimontiers & ... & $\ldots$ & $\ldots$ & 79,876 \\
\hline De Vannes & $\ldots$ & $\ldots$ & $\ldots$ & 98,590 \\
\hline D'Auray ... & $\ldots$ & $\ldots$ & $\ldots$ & 274,849 \\
\hline 'Orient ... & $\ldots$ & $\ldots$ & $\ldots$ & 35,000 \\
\hline Paimpol ... & $\ldots$ & $\ldots$ & $\ldots$ & 105,800 \\
\hline Cancale ... & $\ldots$ & $\ldots$ & $\ldots$ & 595,020 \\
\hline Granville ... & $\ldots$ & $\ldots$ & $\ldots$ & $6 \mathrm{r}, 595$ \\
\hline La Hougue & $\ldots$ & $\ldots$ & $\ldots$ & 183,085 \\
\hline Caen & $\ldots$ & $\ldots$ & $\ldots$ & 96,786 \\
\hline Havre & $\ldots$ & $\ldots$ & $\ldots$ & 121,800 \\
\hline Calais $\quad \ldots$ & $\ldots$ & ... & $\ldots$ & 28,932 \\
\hline Teste & $\ldots$ & $\ldots$ & $\ldots$ & $\mathrm{I}, 736,032$ \\
\hline
\end{tabular}

The dredging in the ports of Granville, Cancale, and L'Orient produced in $1873 \mathrm{I} 2,805,000$ oysters, against $4,586,000$ oysters in the previous year. In 1874 the produce at Cancale was $13,454,000$ oysters.

The following official statement, lately published, gives the statistics of the commerce in oysters in France for the seasons Ist September to 3oth April :-

\begin{tabular}{|c|c|c|c|c|c|c|}
\hline \multirow[b]{2}{*}{1874} & \multicolumn{3}{|c|}{ Oysters taken from the beds. } & \multirow{2}{*}{$\begin{array}{c}\text { Value in francs. } \\
7,727,000\end{array}$} & \multicolumn{2}{|c|}{$\begin{array}{l}\text { Price per 100. } \\
\text { Francs. }\end{array}$} \\
\hline & $\ldots$ & $104,731,350$ & $\ldots$ & & ... & $73 \cdot 78$ \\
\hline & $\ldots$ & $227,640,212$ & $\ldots$ & II $, 247,4$ I 6 & ... & $49 \div 40$ \\
\hline & $\ldots$ & $335,774,070$ & $\ldots$ & $13,226,296$ & $\ldots$ & $39 * 39$ \\
\hline
\end{tabular}


The basin of Arcachon and the other maritime rivers of that coast are those where the artificial culture of oysters has been most attended to. In the season ending April, I $877,202,392,225$ oysters, valued at $4,500,000$ francs, were delivered to commerce from Arcachon. The D'Auray quarter collected and delivered IOI,736,000 oysters, valued at 500,000 francs, during the same period.

The American Oyster Fishery.-The trade in oysters in the United States is very large. The Baltimore oyster beds in the Chesapeake river and its tributaries cover 3000 acres, and produce an annual crop of about $25,000,000$ bushels.

The oyster trade of New York is one using large amounts of capital, employing nearly I 50 sailing vessels, with crews averaging in the aggregate 700 seamen, and handling millions of bushels of oysters per annum. There are moored at the wharfs in New York city nearly 60 barges, or "lay-boats" as they are called, costing from $£ 600$ to $£ \mathrm{I} 000$ each, substantially built, having compartments capable of containing thousands of bushels of oysters in the shell.

The oyster season commences about the ist of October (when the boats owned by the dealers are sent to the beds for cargoes), and lasts until the middle of March or Ist of April. The oyster fleet is composed principally of schooners, ranging from 35 tons to 250 tons, and receives the proceeds of the dredgings of the beds at York River, Prince's Bay, Keyport, City Island, Cow Bay, Rockaway, Oyster Bay, Glen Cove, Blue Point, Norwalk, Stamford, and Greenwich. When the oysters are received, they are discharged directly on the wharf to dealers; and after these are supplied, the balance is stored in the compartments of the lay-boats. From the lay-boats the oysters are 


\section{I40 The Commercial Products of the Sea.}

shipped to other cities at the north and west. For shipment, they are packed in barrels in the shells, or opened and packed in tubs with ice, and forwarded by rail to Boston, Providence, Portland, Chicago, Omaha, San Francisco, and other cities. Very few oysters are canned in New York. That trade seems to be principally monopolized by Baltimore. Besides the oyster shipping interests, there is the important retail trade in the city. The well-fitted and at times luxurious offices on the lay-boats are the meetingrooms of the proprietors of the hotels, restaurants, retail oyster saloons, and cheap oyster stands. At certain hours in the day, representatives of each of these branches of the trade may meet in the office, and the rapidity with which a cargo of oysters-extras, box, cullens-is disposed of astonishes a novice. One man requires only the largest oysters in the lot. Another wants to know if the dealer hasn't got a lot of small oysters for cheap stews. A third requires tip-top box oysters, and another asks when the next cargo of York Rivers or Rockaways is expected.

Most of the dealers own the beds from which they receive the oysters, but are compelled to have partners to superintend the catching and loading, because most of the beds-in fact, all except those bordering on Long Islandare out of the State. The laws of the other States-Connecticut, New Jersey, Delaware, and Virginia-do not permit non-residents to own beds or catch oysters within their domains. So the New York dealers, at least some of them, form co-partnerships with residents near the fishing grounds, supply them with money, let them buy beds and plant the oysters, take them in as part owners of the vessel in the carrying trade, and then divide the profits.

The New York trade is controlled in a great measure 
by.the weather. If the nights are clear and cold, the sidewalks dry, and the stars out, the consumers throng the retail saloons, and the result is an assemblage of all sorts of vehicles in the morning at the lay-boat stations for new supplies. If the country roads are in prime order, and the fast horses of the well-to-do farmers or bloods can make good time to the village, carrying the girls on supper excursions, the demand for new supplies by rail is increased. But when the barometer falls to $29^{\circ}$, the stars go out of sight, the roads are muddy and the sidewalks damp, the demand falls off. Singularly, however, the prices do not fluctuate. The wholesale prices change to so trifling an extent that the consumer never receives the benefit; if any one profits by a fall, it is the retailer.

The oyster trade is one requiring peculiar and delicate perception. Yet the expert who catches the oyster in his left hand, taps it with the butt-end of the knife to make it insensible, and shatters its stony lips to take its life, knows as soon as he lifts it from the pile where it came from, how old it is, whether it is a Delaware, Prince's Bay, City Islander, or has grown under the dashing waves of Rockaway. He knows, too, whether it will open good. The wholesale dealers at. New York have over $£ 600,000$ invested in the oyster trade, and receive on an average $2,500,000$ bushels per annum. During the warm season, the oysters are sent by rail in refrigerator cars, a recent railway improvement.

On some single days, over 100,000 bushels of oysters have been taken from the Chesapeake Bay, which is the greatest oyster bed in the world, and is said to be inexhaustible.

Two hundred and fifty boats are engaged in oyster dredging from Baltimore, which bring in about 900 bushels 


\section{I42 The Commercial Products of the Sea.}

to the cargo; and as they make in the aggregate 6000 trips during the eight months of the season, this gives a total of nearly $5,000,000$ bushels of oysters, worth about $£ 500,000$.

The Newhaven banks have a very high reputation, and this place ranks next to Boston in importance in the oyster trade. Fair Haven is the great oyster mart of New England. Only a very small proportion of the oysters here are natives. They are fully equal in quality to those imported, but cannot be raised in sufficient quantities to supply more than one-tenth of the trade. Of the 4,000,000 bushels imported, about $\mathrm{I}, 600,000$ are brought in the spring and "planted," while $2,400,000$ are imported in the fall and winter, and consumed immediately, some of the largest dealers using as many as 150,000 bushels yearly.

It is estimated that $4,000,000$ bushels of oysters are annually carried from the Virginia waters to Fair Haven; 4,000,000 to New York; 2,000,000 to Boston ; 2,000,000 to Philadelphia; $2,000,000$ to Baltimore ; 3,000,000 to Providence, etc.; in all, more than a score of millions.

The celebrated Chesapeake Bay oysters of America are now regularly received in Europe, and are to be found in the markets of London and Paris. There are several varieties of American oysters, differing mainly in size, according to the districts from which they come. Between the best and the commonest there is hardly a difference of 25 per cent. There is the "Morris Cove" oyster, which comes from New Jersey, and is the kind almost exclusively used in New York and the neighbouring districts ; the "Saddle Rocks," a particularly fat variety ; the "Norwalks," from Connecticut; and other varieties from the coasts of Virginia and Maryland.

The city of Boston plays the same part in supplying 
the Northern States as Baltimore and Fair Haven do for the Central and the Western.

Baltimore is the most important of all the cities engaged in the oyster trade, as far as regards interior and foreign transportation.

Twenty years ago, an official report on the oyster beds of Baltimore gave the aggregate value as follows :-

$\begin{array}{lrrrr}\text { Oysters packed in tins } & \ldots & \ldots & \ldots & £ 600,000 \\ \text { Consumed in the neighbourhood } & \ldots & \ldots & 200,000 \\ \text { Shells converted into lime for agricultural purposes } & \text { 10,000 } \\ & \text { Total } & \ldots & £ 800,000\end{array}$

They obtain all their oysters south of the mouth of the Patapsco river, a great portion by dredging in 20 fathoms water ; these, however, are not so large as those taken with tongs in the numerous shallow inlets and bays, and near the mouth of the Chesapeake. When planting or parking, they take small oysters from deep water, and plant them in places where in three years they grow to a very large size, without being in the least affected by any kind of weather; consequently the increase is unfailing. The number of vessels employed in the trade then amounted to I000, some of which cost $£ 600$, and were capable of carrying 3000 bushels.

The number of houses engaged in this business was then 25 ; the number of hands employed in opening and packing, 2500. In some establishments 3000 bushels were opened in a day, and in all the establishments 17,000 bushels daily. Of this quantity, 9000 bushels were packed in cans in a raw state, and the rest pickled, spiced, and hermetically sealed for exportation everywhere. About half of the packed oysters are consumed in the cities of the Western States, and are invariably sold for cash. Within I 2 years 


\section{I44 The Commercial Products of the Sea.}

the business has increased tenfold, which may be attributed to the facilities of transportation. They now ship raw oysters from Baltimore to South America, California, and Australia, besides all parts of Europe; and the demand will steadily increase as they become better known, from the fact that Chesapeake oysters, like canvas-back ducks, owe their superior flavour to the food obtained on their feeding grounds.

The oysters of the Pacific are beginning to attract attention in British Columbia, and the cultivation of this mollusc and the preservation of oysters in tins for foreign markets will soon become an important industry there.

The Chinese have a mode of raising oysters on bamboo screens in the beds of rivers in the southern ports of the empire. These are prepared for keeping in the following manner:-The oysters, when taken from their shells, are placed for a time in boiling water, and taken out with a skimmer. They are then exposed in the sun to dry. Oysters taken from the rock cannot, it is said, be so preserved.

The number of oysters consumed in Victoria is very large, and averages nearly 15,000,000 per annum. Each year's return manifests a decided increase over its predecessor, and there is every likelihood of this number being doubled if not trebled in the space of a few years, so growing is the passion of "oyster-eating." Oysters are divided there into two classes, viz., "mud" and "rock." Of the former, there are several kinds, varying in quality according to the nature of the ground and the depth of water in which they lie. The latter is generally found in shallow water, bordering on rocks, and is a more delicate oyster than the "mud." Melbourne is supplied from several distinct sources, but the great bulk comes from New South Wales and Tasmania. A few are also received 


\section{Oysters and other Edible Mollusca.}

from Port Albert and Adelaide, and until latterly the Western Port beds yielded a large quantity. The oysters of New South Wales are principally "rocks," and are found in almost every river and inlet in the colony. The best come from the Manning river and Cape Hawk. Those coming from the Hunter, near Newcastle, are very small, and but seldom used. The number of men engaged in the New South Wales fisheries is calculated at almost I000, but it is impossible to state the exact number. The Tasmanian oysters ("mud") are chiefly found in the bays and inlets on the southern coast-the best coming from Port Esperance and Spring Bay. Those brought from the Swan Ports are very inferior. The number of oysters imported from the Tasmanian fisheries is not half so great as it was some years ago; and there cannot now be more than about 50 or 60 men employed, whereas there were formerly more than three times that number. No oysters whatever have been received from Western Port for a considerable period, though from what cause is not precisely known. Formerly there was a fleet of $2 \mathrm{I}$ sailing vessels employed, and the yield then amounted to over I0,000 dozen per week. The few received from Adelaide vary in quality, but none of them possess such a good flavour as the "Sydney rocks," which are more used in the colony than any other class of oysters.

The oyster seasons are:-Of Victoria, from the Ist February to the 3oth September; but this season is considered to commence too early and end too soon. The Sydney rock oysters are allowed to be sold all the year round. The Tasmanian season is restricted to the period intervening between the Ist April and the 3 Ist October; but any party is allowed to gather enough for his own consumption at any time. 


\section{I46 The Commercial Products of the Sea.}

Clams.-Many molluscs pass under the name of clams. The sand or soft clam of the New England States is Mya arenaria; the round clam or hard-shell clam, Venus mercenaria; and both these are brought to market as food. The sea clam is the Mactra gigantea and M. solidissima, Gould ; the razor clam, Solen ensis, Lin.

The soft clam is, next to the oyster, the most important bivalve of the American coast, whether we view it as a means of public sustenance, or as an addition to the fishing industry of the country. Its great abundance on the coasts where it is found, the good market it commands, the ease with which it can be obtained from the banks at low tide, all render it a most valuable source of sustenance to the poorer classes. Clam beds are found in sheltered parts of the coast, or at least in places where the action of the waves is not sufficiently strong to change the character of the banks. The consumption of these molluscs is considerable during every season, but especially in summer, along the entire coast of the Northern States, from New York to Maine; but nowhere is it so great as at Boston. The people of the United States use clams in a variety of culinary preparations, the most popular of which is, undoubtedly, a kind of soup especially esteemed in Boston.

Round clams exist in great abundance on the American coast, from Cape Cod almost to the extremity of Florida. They are generally found on the shores of gulfs and bays, and of the mouths of large rivers which are less exposed to the action of the waves than the open coast. Their beds are at a depth varying from 6 to 25 feet below the surface of the water at low tide. Like all the molluscs of that family, they prefer a large proportion of mud with the sand in which they live.

Round clams are the object of an especial culture in 
America, designed to improve the rapidity of their growth. Like the "paires doubles" (Venus verrucosa) or clams of the Mediterranean, they are never as delicate in flavour as when freshly caught. In summer the consumption of clams in the cities of New York and Philadelphia is very considerable, much greater than that of the Mya arenaria. Like the latter, sold in their natural condition or out of the shell, they furnish many excellent dishes, the most esteemed of which is clam chowder. Many persons eat the smaller specimens raw; and when flavoured with a few drops of lemon juice, they are as palatable as the clovisses (Tapes virginea and $T$. decussata) and the "paires doubles" (Venus verrucosa), which are the especial favourites of the people of Marseilles.

Whatever may be the value of soft clams as a means of sustenance for the people along the coasts, they are still more important to the fisheries of the country. The Americans have for a long time been aware of the marked predilection which many fish, particularly those of the cod species, manifest for the flesh of clams, under whatever form presented to them.

Clams are used for bait, either alive or salted, according as the fishery is on the coast or out at sea. Many years ago it was estimated that 40,000 bushels of clams were consumed in the preparation of salt bait, in addition to large quantities used in a natural state by the coast fisheries.

Cockles, mussels, periwinkles, whelks, and other molluscs: are largely eaten for food in many countries of Europe. 

PART II.

MARINE CONTRIBUTIONS TO INDUSTRY. 


\section{CHAPTER I.}

\section{INTRODUCTORY REMARKS.}

Enumeration of some of the various uses of marine products-Animals-Shells -Isinglass-Fish skins and leather-Fish scales-Various oils, etc.

OF the radiate animals, we have among the useful ones the edible bèche-de-mer or Holothuria (already described), the sea-eggs, sea-urchins, or sea-chestnuts (Echini), which are frequently used as food when full of spawn, and star-fish for manure.

Among those which are ornamental may be named the stony corals, the red "organ-pipe" coral (Tubipora musica), sea-fans and gorgonas, and madrepores.

The vast number of small marine animals, particularly the shell-fish and corals, are of extreme importance to the general economy of nature, acting as scavengers ; inasmuch as they in the ocean, in the same manner with insects upon the earth, incessantly destroy, consume, and as it were metamorphose, an infinite variety of noxious, hurtful, or superfluous substances.

To man they are in so far serviceable that many of the mollusca, or naked soft worms, and the shell-fish are eatable, some forming a principal article of diet to many 


\section{I52 The Commercial Products of the Sea.}

navigators and inhabitants of seacoasts. A very beautiful purple dye was formerly procured to some extent from certain molluscs. Sepia and Indian ink are obtained from the peculiar dark fluid of the cuttle-fish. The gall of the carp is used in Turkey as a green paint and in staining paper. The byssus of certain species of Pinna affords a kind of brown silky fibre which may be worked up into useful articles. Many kinds of shells contain pearls. Red coral is an important article of trade, particularly in the East Indies. Several kinds of shells, either entire or divided, pass current as money in Africa, India, and other remote nations. From portions of shells the North American Indians made their wampum-a sort of currency which serves the purpose of records. Many savage people use mussel, snail, oyster, and tortoise shells for drinkingvessels, spoons, etc. In regard to works of art, the motherof-pearl oyster and many mussel and snail shells are cut like onyx into cameos, and used for making buttons. The cuttle-fish bone is employed by artists and workmen. Sponge serves a variety of domestic purposes. Madrepore is employed for paving and building on the coasts of the Red Sea. Numerous shells and corals are burnt for lime. Some large thin shells are used as glass in the south of China and in India. Shells are among the most common ornaments of savage nations; and shell flowers, shell earrings, shell brooches and bracelets are worn even by females in the more civilized countries.

It is not as nourishment only that fish is made subservient to commerce. The preparation of isinglass affords to some countries the means of extensive trade and speculation. Sole skins, if clean, sweet, well prepared, and dried, can be used as a fining agent, and are sometimes employed in households to clarify coffee. It may be 
mentioned that the stomach, the intestines, and also the skins of different kinds of fish can be used as isinglass after being cut and submitted to the action of boiling water, and then pressed, which gives the substance the appearance of thin leaves, resembling parchment. The skins of many are utilized. Leather is largely made from seal and porpoise skins, and also prepared from scaled fish by the North American Indians; eel leather is used for whips and flail thongs; shagreen or shark leather, used by the Alaska Indians for boot soles; there is also a sturgeon leather. The skins of Diodon are used in making helmets, and the stomach membranes of the halibut, in Greenland, for window transparencies: Parchment is made from the viscera of seals, and used by the Eskimo for clothing, bags, and blankets. They also employ the pharynx of the seal or walrus as leather for boot soles. Beluga leather is dressed as kid, sole, harness, boot, mail bags, belts, and pattern leather, etc. Walrus leather is used by the Eskimos for harness, tables, thongs, seal-nets, and in Europe for covering polishing wheels. The Eskimos also use sea-lion leather to cover bidarkas, and for garments and beds.

Oil is largely obtained from fish for medicine and use in manufactures. From the mammals we obtain-seal oil, in its various grades, used for lubricating; sea-elephant and sea-lion oil; dugong oil; oil from the body of whales, grampuses, and porpoises, employed in the arts, for lubricating, painting, etc. ; black fish and porpoise-jaw oil, used in lubricating fine machinery, watches, clocks, and guns; grampus oil and sperm oil, used in lamps, for lubricating, as an emollient in medicine, for lip-salves, and in the manufacture of spermaceti. The fish oils comprise, among others, sun-fish oil and cramp-fish oil, used by fishermen for the cure of rheumatism; cod oil and cod-liver oil, used in 


\section{The Commercial Products of the Sea.}

medicine, as a food and emollient, and in lubricating; hake and haddock-liver oil, used in adulterating cod-liver oil ; pollock oil, used by the Shetlanders for illumination; menhaden oil, used in currying leather, in rope-making, for lubricating, as a paint oil, and exported to Europe for the manufacture of soap and for smearing sheep. Herring oil, white fish oil, sturgeon oil, shark oil, and many other oils obtained from fishes, and a large part of the seal and black whale oil are known indiscriminately as fish oil, and employed for various manufacturing uses. Oulachan oil is used by the Indians of the north-west coast of America, for food and illumination. Shark and skate liver oil, including the "Rouen oil," made on the coast of Normandy from the liver of Raia aquila, R. pastinaca, and R. batis, are used like cod-liver oil.

The bones and débris from the menhaden, herring, cod, and other fisheries form fish guano. The scales of fish are used in ornamental work, in manufacturing flowers and other fancy articles. Among those so employed are the scales of parrot-fishes (Scaridee and Labride), of mullets (Mugilide), of sheep's-head, etc. (Sparide), of drum and bass fish (Scianida), of Serranide and perches (Percidce and Labracide), of Lobotide, of tarpum (Elopida), of herrings (Clupeide), of Cyprinide; of eels, used in the north of Europe to give a pearly lustre in ornamental house-painting; of gar pikes, used by Indians for arrow tips; also those of sturgeons, for implements. Pearl white, or essence d'Orient, prepared from the scales of Alburnus lucidus and other Cyprinidae and Clupeida, is used in making artificial pearls. The shagreen of the trigger-fish (Balistes) is employed in polishing wood ; that of sharks as leather and for polishing purposes, particularly in the manufacturing of quill pens. 


\section{( 155$)$}

\section{CHAPTER II.}

SPONGE AND THE SPONGE FISHERIES.

Description of sponges-Two scientific divisions, common and fine-Commercial grades-Distribution of sponges-Cup-shaped and fistular sponges -American sponge fisheries-Mode of procuring and cleaning them.

SPONGE is a substance with which almost every one is familiar, as there are but few families or individuals living in civilized communities who do not find occasion to use it for a great variety of purposes. The article is so very useful that a large number of inconveniences would arise if it could not be obtained. What would the surgeon do? what the traveller? what the housekeeper? And yet most of those who use sponges in an indefinite variety of ways all their lives never stop to consider how they are formed; whether they are plants or animals, or what are their history and habits.

Sponges consist of a framework or skeleton, coated with gelatinous matter, and forming a non-irritable mass, which is connected internally with canals of various sizes. The ova are very numerous, and present in appearance the form of irregular-shaped granules, derived from the gelatinous matter, which grow into ciliated germs, and, falling at maturity into the small canals, are then expelled by the orifices. When alive, the body is covered by a gela- 
I56 The Commercial Products of the Sea.

tinous film, which, being provided with cilia, causes a current of water to pass in at the smaller pores and out at the larger apertures, the sponge probably assimilating the nutritive particles which enter into the water.

FIG. 4 .

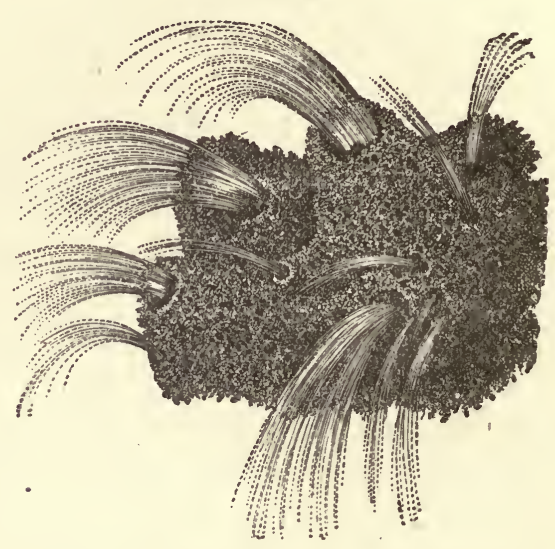

Sponge showing the outgoing water currents.

A monograph of these polypes, published in the 2oth volume of "Des Annales du Museum, Paris,". enumerated I4I species, ranged under six divisions.

The sponges of commerce are divided into two scientific divisions :

I. Comprehending the common sponges (Spongia officinalis), of rounded or flat form, convex beneath, of soft tissue, more or less tenacious, large pored with great orifices.

2. The second division includes the fine sponges (Spongia usitatissimum), of concave or cup-like form, having the oscules slender like hair, and the pores very fine in the interior. Of these there are 34 species. 
Sponges are found abundantly in tropical waters generally, and perhaps nowhere more abundant than in the seas of the Australian islands. They gradually decrease in numbers towards the colder latitudes till they become entirely extinct. They vary much in shape. Some are beautifully shaped like a vase, others are semi-cylindrical, others nearly flat like an open fan; some are branched like the opened fingers of a hand, and are called glove sponges, and in others these branches seem to be reduced to only one, which is shaped somewhat like a club. These varying shapes may belong to one species, and the differences are due, so far as known, to the fact that the first mentioned are found in deep water, and they grade, in the order described, up to the last, which grow in much shallower water.

The commerce in sponges is of considerable importance. From a very elaborate and learned paper in a recent number of the "Memoirs of the Boston Society of Natural History on the North American Poriferæ," with remarks upon foreign species, we derive the following valuable information on the characteristics and classification of the commercial sponges. The great difficulty which is experienced in any attempt to distinguish species results from the extreme susceptibility of all keratose sponges to any change in external conditions. They appear to require for the production of the forms in abundance tropical or sub-tropical seas, and attain by far their greatest development in the number of the forms and species in the West Indian seas. The typical forms, the commercial sponges, are essentially confined to the waters of the Caribbean Islands, the Bahaman Archipelago, and the southern and western coasts of Florida in the western hemisphere, and to the Mediterranean and Red Seas in the 
I58 The Commercial Products of the Sca.

other. Australia affords a few forms; and some species are said to be found on the Atlantic coast of Brazil. Bermuda also has a few of the commercial kinds, which, according to Mr. Goode's report and his suite of specimens, are much coarser than the Key West, darker in colour, and, in fact, just about intermediate between these and those of Australia. They are occasionally found in the shops, but, as a rule, are used only by the fishermen themselves about their boats, the Bahamas sponges being preferred for domestic purposes by the inhabitants. It appears that the finest forms grow only in the protected lagoons, at depths varying from 5 to 25 feet, on a sandy bottom. The temperature is not stated. They are cured in a very careless manner by exposure to the weather, a process which doubtless does not increase their value. The true Spongic are all shallow-water forms. In the Mediterranean, according to Von Eckhel, they are not found below 30 fathoms, and in American seas about the same probably, though not fished to greater depths than five fathoms. The fishery is principally carried on in the West Indies by the aid of a sort of hooked fork, two shepherd's-crook-like hooks on a long pole. The fishermen cannot so successfully work at considerable depths with this instrument, as by diving, or with the diving apparatus or armour, and various forms of drags, etc., employed in the Mediterranean. The greater part of the fishery is accomplished between the depth of 3 and 20 feet, according to the report of Dr. Palmer, from which these remarks are principally derived. The finest qualities of American sponges are obtained in the Bahamas, the principal depôt being at Nassau.

The process of preparation is not so careful as in Europe, probably owing to the greater coarseness and 


\section{Sponge and the Sponge Fisheries.}

cheapness of the specimens. The actual fishing is done from boats, generally belonging to some schooner or larger craft. The boats are sent out from the vessel manned by two men. They are generally sold by the cargo. The bases are clipped off, and the sponge trimmed with shears and packed in pressed bales for transportation to New York or England, where they are largely used for the manufacture of pilot cloth, hats, etc. The coarser kinds and clippings are also used extensively for stuffing mattresses, carriage cushions, etc., in place of hair. They are not of sufficiently good quality to compete with the Mediterranean sponges, and are therefore rarely employed for domestic purposes, except in Great Britain and the countries of North and South America. The fisheries near shore are abandoned in the winter on account of the turbid state of the water, which becomes "milky" with suspended coral sand during the more tempestuous months. A more limited fishery, however, is still carried on at Anchor Keys, some 35 miles outside of Cedar Keys, and in other places where the water is stiller, clearer, and warmer than nearer shore.

The commercial grades coincide very closely in America and in Europe, but it is easy to show that each of them may be considered a distinct species if one has an inclination to multiply in this direction. The grades are glove sponge (Spongia officinalis), sub-species tubulifera; wool sponge (Spongia equina), sub-species gossypina; and yellow and hard head (both under the name of Spongia agaricina), sub-species corlosia. These correspond with remarkable accuracy to the three principal grades of commercial sponges in Europe, which are the bath sponge (Spongia officinalis), the horse sponge (Spongia equina), and the zimocca sponge (Spongia agaricina). 
This result, in which three species appear on both sides of the Atlantic as representing alone the marketable qualities of the genus Spongia, becomes of double interest when these varieties, or local species as they might be called, are compared one with another. It is then found that the aspect of the surface is closely similar in each of the three ; that sub-species tubulifera represents Spongia officinalis, sub-species gossypina offsets Spongia equina in the same way, and lastly, sub-species corlosia has the same relation to Spongia agaricina. In order to make it still more convincing that such a relationship is not the result of an artificial arrangement, it becomes necessary to describe some of the facts more at length. First, their similarities of surface and aspect are precisely the same as those which experience has led me to adopt in the designation of species in this group. Secondly, their differences can be accounted for by the difference in habitat, and are of varietal and not of specific value, according to the accepted use of the term species.

The whole group of Keratosa is confined to seas in which the differences observable between the winter and summer isotherms are not excessive. None are found north of Cape Hatteras and Bermuda, and doubtless a similar limit occurs to the southward of the equator; at least, it is a noticeable fact that the only specimens in the Museum of Comparative Zoology are from the island of Fernando Noronha. On the Pacific shore, Southern California and Chili are the extreme points so far known. On the opposite coast of the Atlantic they are recorded from England to the Cape of Good Hope, and also at the island of Teneriffe. In the Indian Ocean they are found all along the east coast of Africa, at the Mauritius, and on the shores of India. They have been described from the 
southern part of the Sea of Okhotz, on the Asiatic continent, and specimens are not uncommon on the coasts of Australia and New Zealand. In the Pacific they have been found at the Kingmills Islands and Hawaiian Islands. The extreme outlying form to the north, on both sides of the Atlantic, is the excessively coarse Dysidea fragilis, with its fibres loaded with débris. Those from the Cape of Good Hope and Southern Australia also belong to the coarser genera. The species cited by Miklucho Maclay from the Sea of Okhotz seems to be one of the Phyllospongida, but there is no analysis of the characteristics of the skeleton, only the external form being described and figured in his article on the sponges of the North Pacific ("Mémoires de. l'Acad. Imp. de St. Petersburg," vol. 75, No. 3). It would seem, therefore, that the finer skeletons of the Keratosa, those of the genus Spongia, are only to be sought in the intermediate zone, where the waters are of equable and high temperature. Again, in examining the species of this genus with relation to each other, it becomes equally evident that they are finest and most numerous in archipelagoes, or off coasts which are bordered by large numbers of islands, or long reefs, or in sheltered seas.

Mr. Gurdon Saltonstall states that the sponges near Nassau lie on reefs very much exposed to the action of the waves, often 30 miles from land, and always in currents, sometimes running three or four knots an hour. Such currents are usual wherever groups of islands confine the tide water within certain definite channels, and they have also the effect of concentrating the floating food in the channels, or wherever tides meet. Both of these conditions are essential to successful sponge growth, namely, a continuous renewal of aerated water and a plentiful supply of food, and are probably partly the cause of their abun- 
I62 The Commercial Products of the Sea.

dance in such places. This entirely agrees with observations made upon many species on the North American coast of Chalinince and Halichondrida. Constant reference to physical influence is also noticeable in the map prepared by Von Eckhel, and in the method of classification adopted by him. The marketable qualities are described as "sorts," and the different " sorts" designated by letters, as "sort A," "sort B," and so on. These sorts he has found it most convenient to arrange according to localities, and thus under some "sorts" we have all the three species represented; all, however, from the same place, and all having some local peculiarity which makes them either of superior or inferior quality. The author also frequently refers to the slimy character of the bottom as a reason for inferiority or dark colour. On the American side of the Atlantic this is also shown by the great difference in point of colour and fineness between the Nassau and Key West sponges. The former are lighter coloured, finer, more elastic, and more durable, than the same species at Key West, where the colour is so dark that it designates at once the locality from which the specimen came.

Again, the shallow-water sponges are coarser than the deep-water forms. This is probably due, in part, as in other species, to the quantity of sediment, which is of course less in deep than in shallow water, as, for example, at Key West in the winter time. Mr. Saltonstall, who made inquiries among the spongers, states that no fine qualities of any sponges are found within the limits of the milky water, but all the finer qualities of the marketable kinds in the deepest water in which the species occur, except, perhaps, in the case of the reef sponge. Glove, reef, and hard head are fished in shallow waters, greatest depth two fathoms, and the other and generally finer marketable varieties from two 
to five fathoms. This fact also explains, in a measure, but not wholly, the greater coarseness of American sponges as compared with the European; for though it may be assumed from the examination of the skeletons that Mediterranean sponges are much less exposed to turbid waters, and though it may be shown by the microscope that the primary fibres contain less débris, this does not wholly explain their greater fineness and elasticity. We may attribute this either wholly or partly to climatic conditions.

If either the temperature or density of the water had been exceptional, we might have gained some additional information, but as it is, we cannot assume that either cause would have been sufficient to account for the absence of the Spongice from the Euxine. According to Carpenter, in his articles on the Mediterranean and Black Sea, there is a strong current continually flowing at the depth of 20 fathoms from the Mediterranean into the Black Sea, and a return surface current from the Black Sea into the Mediterranean. The sponges occur necessarily in the shallower waters of the Sea of Marmora, since they are said by Von Eckhel to be fished for mostly with the harpoon, and are probably exposed more or less to the influence of the surface current. Under these circumstances, they must very often be able to endure a degree of cold during the winter, and an amount of change in the density of the water, for which it becomes difficult to account, even taking into consideration the inferior quality of their skeletons. It is possible, however, that the water of the northern part of the Black Sea may not affect the temperature of the southern part to such an extent as would at first sight appear probable, and that, notwithstanding the lower temperature of the northern shores, the general temperature of 


\section{I64 The Commercial Products of the Sea.}

the surface water during the winter immediately east and west of the Bosphorus may not fall below $55^{\circ}$ as a minimum.

The northern shore of the Ægean Sea and the eastern shore of the Adriatic Sea are populous with sponges, and yet the former throughout its whole extent, and the latter from Ragusa to Istria, have nearly the same average winter temperature, and possess a colder climate in winter than the coast of southern Italy or Spain, where no Spongice exist. Again, upon consulting the invaluable little Eckhelian pamphlet, we find that the sponges correspond in quality to this climatic change. The sort found at the head of the Egean is said to be the Spongia officinalis alone, and to have a "heavy, hard, close, very hairy skeleton, often containing slime," and it is further added that it is not much liked, and is usually fished with the harpoon. The same species exist also alone at corresponding localities along the shore of the Adriatic, and at the extreme locality, the island of Istria, upon the limit of its distribution, it is said to be very rare, the form to be ugly, the skeleton hard, the colour dark. Farther south, along the Dalmatian coast, it becomes abundant, finer in texture and of a lighter colour, but it is still inferior to the more southern or Levantine variety. In considering such classes of facts, it must also be borne in mind that the habitat of a certain sort of variety may largely determine the quality of the skeleton, even where the temperature may be very favourable. Thus, to the south of Quarnero, among the islands, a much better quality of Spongia officinalis occurs than in the milder sea about the Ionian Islands, which, as Eckhel remarks, is probably attributable to the slimy character of the bottom.

The finest sponges in the Mediterranean, those of the 
Levant and off the Syrian and Tripoli coasts, are found between the average aerial winter temperature of $63^{\circ}$ and $70^{\circ}$, and the isochrymals of $50^{\circ}-57^{\circ}$, and at no time of the year are these, which, as stated, by Von Eckhel, occur in the deeper water at a distance from the coast, probably exposed to a lower temperature than $60^{\circ}$.

In describing the species of this genus I have made comparisons between three principal Mediterranean and three of the American commercial sponges, in order to show the very evident relationship of these forms. Schmidt describes five Mediterranean species in all, and may be right; but so far as I can understand his descriptions, with the aid of a fine collection of specimens purchased by Professor Baird for the National Museum from Mr. Isaacs, of New York, I cannot make more than three out of the ordinary commercial varieties, which were fully represented, and appeared to include the entire range of his five species. Von Eckhel's work upon the "Badeschwämme," although a purely commercial treatise, has the same view of the affinities of the sponges, based upon the observations of the fishermen and dealers, and the distribution of the species. The latter is quite remarkable. Only one species, the Spongia officinalis, Lin., Adriatica, Schm., is found on the eastern shore of the Adriatic and coast of Greece, from Trieste to the Bay of Nauplia. From Nauplia and the island of Candia to Eritra, on the coast of Asia Minor, two occur, Spongia officinalis and Spongia agaricana, Pall., Zimocca, Schm. From Eritra, opposite the island of Chios, to Tripoli, all three, Spongia officinalis, agaricana, and equina, are fished, except at the island of Cyprus, where the zimocca sponge does not live. From Tripoli to Tunis two only occur, Spongia officinalis and equina, and from thence to Ceuta, at the Straits of Gibraltar, a very peculiar dark- 
coloured and coarse variety of the Spongia equina is obtained, called the gerbis sponge.

The distribution indicates the naturalness of the three species, and shows also that the dealers have to do with a vast variety of forms. They can, however, pick out the three species and their varieties without hesitation, and I was amused and interested at finding that the method pursued was precisely similar to that which I had been

FIG. 5.

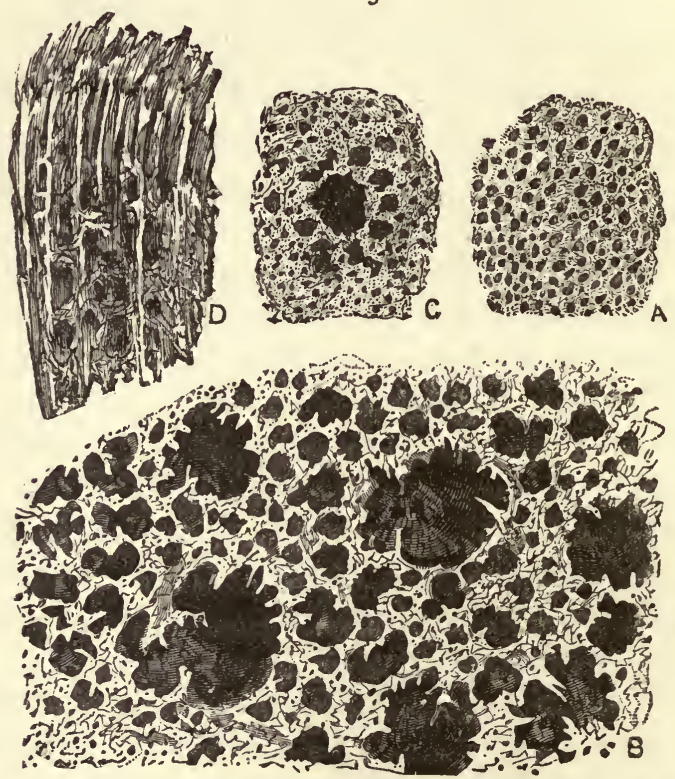

Outer surface of different kinds of sponge (natural size). A, Cup-shaped variety; $\mathrm{B}$, honeycomb sponge; $\mathrm{C}$, toilet sponge; $\mathrm{D}$, Bahamas sponge, partly in sections, showing projecting extremities and internal tubular character.

obliged to adopt in distinguishing empirically the various sub-species and species of Spongia. They are led mainly by the general aspect of the surface. This has a distinct 
appearance in every species, and though much altered by the greater or less development of superficial tufts, is much more constant than any other character. This is due to the fact that the surface takes its aspect largely from the number, distribution, and size of the pores, cloacal orifices, superficial canals, and primary fibres. These characteristics, of course, are directly correllated with all that is important in the internal anatomy of the animal, and should therefore be more constant than the length, form, or composition of the tufts of fibres, or the shape of the whole, which are capable of great modification, according to the locality in which the specimen may be found. The forms of Spongia officinalis may vary from cup-shape to fistular, and to irregular or lump-like. The latter are usually coarser and looser in texture, the superficial tufts are longer and more numerous, and they approximate more closely to the coarser varieties of sub-species tubulifera of the Caribbean Sea in the external aspect of the surface and the apertion of the interior, than the finer varieties.

The texture of the poorest variety of the Mediterranean sponges is, however, always better for domestic purposes than the best of the corresponding American varieties, being firmer and more elastic ; and it is also to be remarked that the last never have the cup-shape, which is so common in the sub-species Mediterranea, and that the fistular form takes its place. The forms of Spongia agaricina, sub-species $Z$ imocca, vary from saucer-shape to irregular, lump-like growth. As in the Spongia officinalis, it may be shown that these aberrant forms are quite similar to the aberrant or formless varieties of the sub-species punctata of Florida, as regards the aspect of the surface; but these also are nevertheless much finer than the finest varieties of the latter. Here, again, the platter or saucer shape, which is 


\section{I68 The Commercial Products of the Sea.}

a modification of the cup-shape, is absent. Spongia equina exhibits similar degrees of variation in the texture of the surface and the form. There are no proper cup-shaped specimens among the American varieties of sub-species gossypina, but in place of these the fistular form. These occur generally associated in clumps, more or less densely filled up into heads, and solid, but sometimes the tubes are almost isolated. The younger specimens of this species have a very loose and open texture, due to the approximation and large size of the openings, and to a less degree this is also to be remarked in the gerbis sponge. The former approximate in aspect to the coarser qualities of the American species, and so also does the latter, which has very nearly the same colour and aspect as the darkcoloured Key West specimens, but it is not so coarse or dark. It seems, then, that there are three sub-species of commercial value in the Mediterranean, which find their way into the New York and European markets. The coarsest varieties of the European sponges are finer, firmer, and more elastic than the finest of the corresponding American sub-species. This is directly traceable to the larger amount of foreign matter included in the primary threads, the looser mesh of the tissue; the fibres are also comparatively coarser and the large cloacal channels more numerous throughout the mass.

Thus the different varieties of sub-species gossypina differ in an exactly similar way from each other, and from the third form, sub-species cerebriformis; they differ in texture, in surface, and also in habitat, the finer kinds, as stated previously, being found in the deeper water, equally removed from excessive heat and excessive sediment. These three sub-species run together by means of specimens of the coarser varieties, which cannot be distinguished 
Sponge and the Sponge Fisheries. $\quad 169$

FIG. 6.

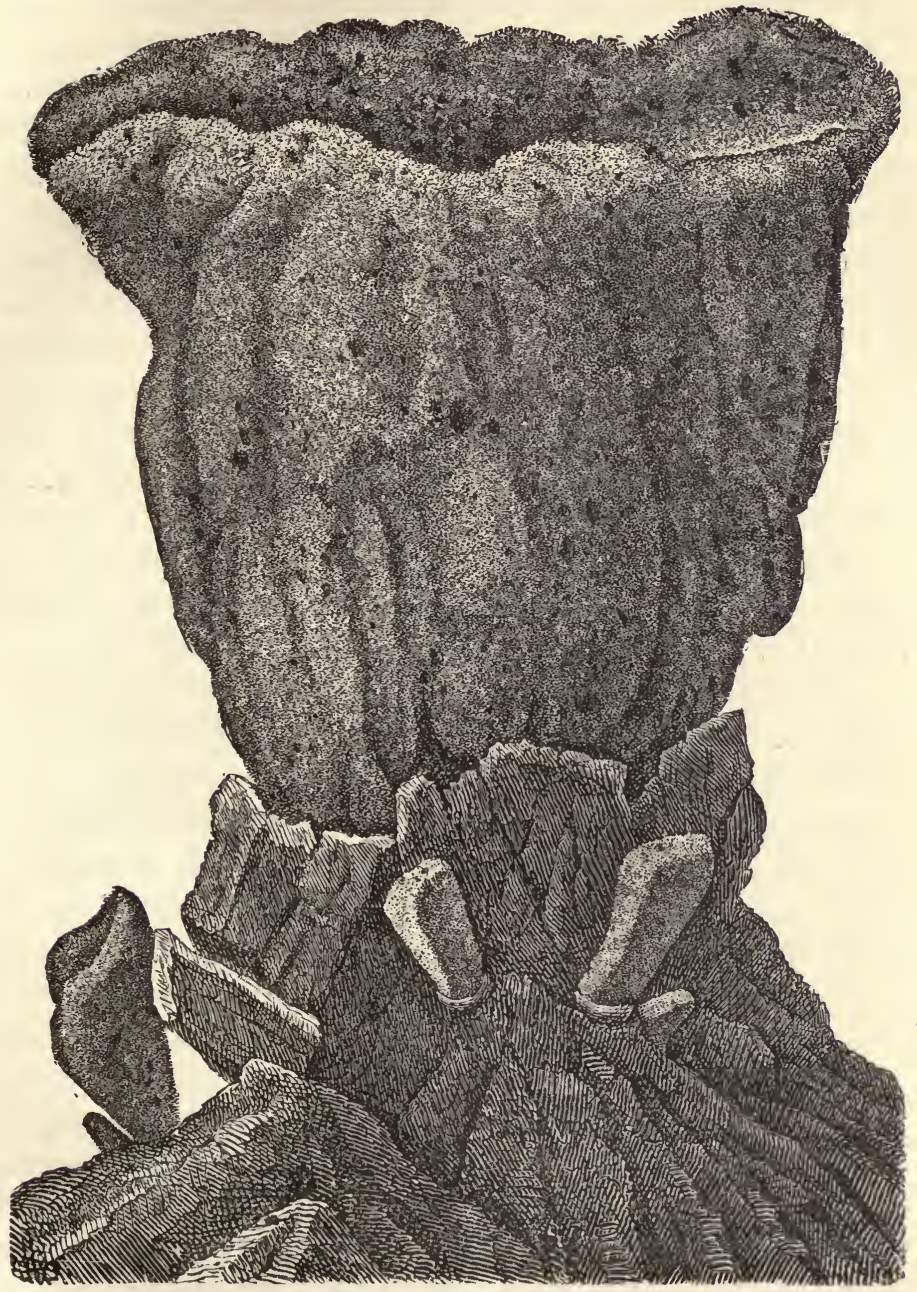

Cup-shaped sponges in natural position, rooted to rock. 


\section{70 The Commercial Products of the Sea.}

from each other with any certainty, in the same manner as the corresponding sub-species in the Mediterranean and Caribbean Seas were connected, through the coarser, and not by the aid of the finer varieties. It is evident, however, that besides the general differences previously noted, the cup-shape form is not found in the American subspecies, whereas it is the prevalent form of the Mediterranean sub-species. A cursory examination of a large collection will, however, satisfy any one that the shape does not necessarily correllate with a finer or a coarser skeleton, but probably with a more or less extended base of attachment and local peculiarities, such as currents, and the kind of bottom, etc., which have not been investigated in this connection.

The American Sponge Fisheries.-The coarser descriptions of sponge entering into commerce are procured about the Bahamas banks and the coast of Florida.

Sponge fishing is said to have become a very profitable business in the neighbourhood of Key West, Florida. The article is mostly procured there by the natives of the Bahamas, who best understand the business of sponges; and its principal grounds are Rock Island, a scope of land 30 miles long by seven miles broad, lying off Taylor county and 60 miles north-west from Cedar Keys; thence from the mouth of the Withlacoochee, past Martin's Reef to near Tampa Bay, a distance of perhaps 300 miles.

The number of small schooners engaged is between 75 and IOO, with an average of from 5 to 15 men to each, and an average of three dingies to each vessel. The vessels built for the purpose are half oval-shape, and as flat as is consistent with due regard to sailing qualities. Dingy, or dincey, is the small boat used to gather the 
sponge, and is usually managed by two men. There are about 600 men daily engaged in gathering when the weather is fair. Quiet weather and calm sea are always taken advantage of. These dingies, when likely to be called into service, are towed Indian file at the stern of the larger vessel. Each sponger is provided with a "spongehook," made of iron, with three prongs, a socket fitting on a pole one and a half inches thick and from 18 to 35 feet long; also a "water-glass," a bucket with a pane of glass fitted in the bottom. This adds to the power of vision by excluding the light from behind, enabling the sponger to penetrate with his eye at least ro or I 5 feet deeper into the water. The sculler propels the boat along very slowly; in the mean time the sponger sits hanging over the side of the dingy with his head at the bucket held by the hand and his eye penetrating the depths below, taking in all that passes within his line of vision. As soon as he sees his legitimate prey, he raises his sponge-hook with his right hand, in which he is assisted by the sculler, still keeping his eye at the glass, grapples the sponge, then puts aside the glass and hauls it in.

Frequently his sight is darkened and view obstructed by the intervention of the monsters of the deep. A huge shark, a sawfish, or perhaps an enormous devil-fish, very often large schools of beautiful fish, "Spanish mackerel," " cavallie," "sailor's choice," " pompeno," pass beneath him in such numbers as to seriously interfere with his occupation. Again, his sight is regaled with lovely coral formations, deep fissures and grottoes, gem-lined within.

When a dingy load is gathered, the sponges are taken to the vessel, where they are placed roots down, eyes up, until they are dead. This part of the sponge fishing is the most disagreeable, and causes the vessel to be almost 


\section{I72 The Commercial Products of the Sea.}

unbearable, the sponge exhuming a bloody, slimy matter of most offensive odour.

The vessel having secured a full cargo makes for port, when the sponges are taken ashore and buried in the sand in a place technically called a "crawl." It is generally constructed of a paling of oak staves driven in the sand, and the lee of some island is selected as the spot. The sponges are left a week or longer, when the slimy flesh, as it may be called, having rotted off, the sponger goes into the crawl with a "bruiser" (a small paddle), and with a few strokes on the top of the sponge, clears it from the filth and skin; after which it is assorted into the different varieties, collected upon strings of convenient length and bleached in the sun, when they are ready for the market.

The sponge on the bar grows something like a bed of cabbages or mushrooms, and presents a beautiful appearance, very dark and seemingly having eyes. The sponge reefs in deep water are called "feather bars," from the feathery or fan-like appearance of the coral, very often seen growing up through the sponge, and in such places the larger sponges are generally found. The different kinds of sponge found on this coast are known as "loggerhead," "sheep-wool," "turtle-grass," and "yellow." The sheep-wool and yellow only are marketable. The latter is worth Is. per pound; sheep-wool averaging 4 s. per pound.

There are two sponge seasons proper, during the winter and summer months; should the water continue clear, however, it then lasts all through the year.

The common practice is to gather sponge on shares, the vessel getting one-third and the crew two-thirds, the provision bill being assessed in the same ratio. The 
Sponge and the Sponge Fisheries.

sponges gathered in Florida waters are taken from the fishermen at Key West, Cedar Keys, and Apalachicola. The amount of money paid out per annum is as follows :At Key West, £24,000; Cedar Keys, £1 3,000 ; Apalachicola, $£$ I r,o00-a total of $£ 48,000$. 
I74 The Commercial Products of the Sea.

\section{CHAPTER III.}

\section{THE SPONGE FISHERY OF THE BAHAMAS.}

The Bahamas sponge grounds-Statistics of the fishery-Gathering and cleaning the sponge-Eleven sorts specified-Value of the exports from BahamasNew uses for sponge-Bleaching sponges-Reproduction and transplanting sponges.

Bahamas Sponge. - About 500 vessels are constantly engaged in the trade, 3000 men find employment, and through it $£ 20,000$ to $£ 30,000$ sterling are annually circulated and spent in the colony.

The great sponging grounds lie to the east, west, and south of New Providence. Although often far from the shore, and at a depth of 20,40 , or even 60 feet, it can easily be descried through the transparent waters on the clear sandy bottoms, from which it is raked or grappled up.

From William's Cay, Andros Island, the fine qualities of glove sponge are obtained. This kind is used principally for surgical purposes, and is sent generally to America, as the Mediterranean supplies Europe with this description of sponge.

The process of cleaning the sponge here is very simple. It is kept on the decks of the vessel until it is quite dead, when it is thrown into a "crawl" made for the purpose, 


\section{The Sponge Fishery of the Bahamas.}

through which the tide flows, and left to soak from four to six days, when it is beaten with a flat piece of stick, and then becomes quite clean. A few years ago the practice was to bury the sponge for 20 days, by which time the gelatinous animal matter was destroyed or eaten away by the insects that swarm in the sand. This has been entirely done away with; the present custom is more simple, and cleans the sponge better. The sponge is then assorted and compressed in powerful presses like cotton. Each bale or package has fastened to it outside a sample to show the quality.

Strange to say, spongers, as a rule, are not very good judges of the quality of the sponge they gather. They seldom seem to know good from bad sponge. The consequence is that much of very inferior quality is brought to market, and realizes very low prices. This is an evil which could easily be remedied. The gathering and cleaning of common sponge entails as much trouble and fatigue as the collecting of what is valuable and good. Spongers should be more observant of the various qualities of sponges. They ought to know a sound from a sucked sponge-a sponge of fine texture and good shape from one of bad shape and coarse.

Bahamas sponge is classified into II sorts. From the south-eastern extremity of Andros Island, and all over the Exuma banks, the fine large sheep-wool or honeycomb sponge is chiefly found. This kind is known as the bath sponge, and is by far the most valuable and merchantable. The other kinds are the reef or fine toilet, the boat, the velvet, yellow, hard head, Long Island, grass, common or glove, and refuse. None of these are very valuable, excepting the velvet sponge, which is obtained from the west end of Bahamas and William's Cay. From these two 


\section{I76 The Commercial Products of the Sea.}

places this kind of sponge, although coarse, hard, and common wherever else obtained, almost equals the far-famed Turkish sponge in texture, and is very nearly as valuable as the sheep-wool. From the extensive banks to the southeast of Andros Island, a very inferior and coarse velvet sponge is gathered, which is brought in large quantities to market; being tough and soft, it is much used in stables. It does not realize a high price, but the sponging vessels more than make up for the inferior quality by the immense quantity which can easily be obtained. New tracts of sponge are seldom found. Spongers, as a rule, seem to prefer to sponge upon the old, well-known grounds, which, by being frequently searched, are consequently nearly worked out. There are unquestionably immense fields of sponge all over the banks that yet remain undiscovered-sources of future wealth which will be opened up in time to those who seek them. Sponge is taken from the bottom of the sea here by means of a hook attached to a long staff. The length of the staff required is usually 25 feet. The best qualities of sponge are found in the deepest water, excepting the fine glove.

In 1875 great exertion was made to procure the better classes of sponge, viz., wool, reef, velvet, and boat. The demand for these kinds was somewhat greater, and the prices ranged higher. It is, however, more and more apparent to those who watch the lots as they arrive in the market, that the proportion of sponges of suitable size for the trade is decreasing gradually; and unless new beds are discovered, or the coarser kinds, of which large quantities exist, can be utilized, or the fisheries of Cuba be opened to the Bahamas spongers so as to allow time for the young sponge in the neighbourhood of these islands to attain sufficient growth, a large number of those engaged in the 
business will have to withdraw, as even now it hardly compensates them for their labour.

The rapid strides made in sponging within the Bahamas group appears almost incredible. It only commenced in I84I. The early stages of the trade a quarter of a century ago, and its progress since, are shown in the following statistics :-

Value of the Exports from the Bahamas.

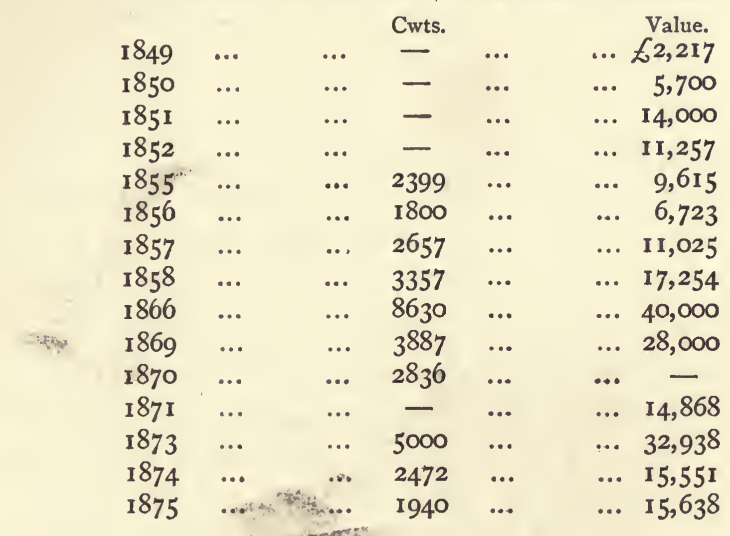

About half the quantity collected is shipped to the United States, and half to England.

Before sponges pass into commerce they are trampled on, pressed, washed a great many times in salt and fresh water frequently changed, until the gelatinous mucus with which they are covered has disappeared. They are then passed through boiling water, with the view of ridding them, if possible, of the peculiar smell arising from the animal matter attached to the fibrous tissues.

To bleach sponges, they are steeped in a dilute solution of sulphuric acid of $\mathrm{I}$ to $\mathrm{I}^{\circ} \mathrm{O} 3$ degrees, and they are left to steep five or six days, taking care to press them from time to 


\section{its The Commercial Products of the Sea.}

time. It is necessary before the bleaching to remove any calcareous matter which may adhere to the sponges, by soaking them for about an hour in dilute hydrochloric acid.

The following is the chemical analysis of sponge :-

$\begin{array}{lllllr}\text { Carbon } & \ldots & \ldots & \ldots & \ldots & 47 \cdot 16 \\ \text { Hydrogen } & \ldots & \ldots & \ldots & \ldots & 6 \cdot 31 \\ \text { Nitrogen } & \ldots & \ldots & \ldots & \ldots & 16 \cdot 15 \\ \text { Oxygen } & \ldots & \ldots & \ldots & \ldots & 26 \cdot 90 \\ \text { Iodine } & \ldots & \ldots & \ldots & \ldots & 1 \cdot 08 \\ \text { Sulphur } & \ldots & \ldots & \ldots & \ldots & 0.50 \\ \text { Phosphorus } & \ldots & \ldots & \ldots & \ldots & 1.90 \\ & & & & & \frac{100}{10}\end{array}$

If sponges were more generally abundant in commerce and somewhat cheaper in price, many more uses might be found for them. Thus, they would make excellent material for stuffing beds and furniture-a use to which they have already been put in America-for large and white tissues for purifying and filtering liquids, paper stuff, etc.

One of the uses to which sponge has of late years been applied in America is to make what is termed elastic sponge for stuffing in upholstery purposes. The raw sponge is received in hard, dirty masses, filled with sand and bits of shell. Being soaked in a large tank of water, it expands into such condition that its quality may be determined, and it is then sorted into two kindsthe "soft" for mattress stock, and the "hard" for cushions.

The cleansing process, which is an exceedingly important one, then begins in another room. In order to effect this, the sponge is first cut and washed, by passing for an hour through a huge tube, in which there is a series of knives, through which the sponge is made to pass by means of the movement given to the water by a wheel. The water, too, is constantly changing, so that by this process the sponge is nicely cut, and its filth separated in part. It 
is next soaked for 20 minutes in a tank of water, containing $2^{\circ}$ (hydrometer) of soda ash and heated to $150^{\circ}$. It is then passed into a tank containing a hot solution of very strong detergent soap, where it is soaked for half an hour with constant and violent agitation. It then returns to the first tub, where it is washed another hour and cut more finely. The cleansing process is then complete, and after the water has been pressed out by passing through rollers, it is carried by the elevator to the "drying-room," two stories above, where a high degree of temperature is maintained, and it is dried in large revolving cylinders. It is then clean and without smell, but hard and inelastic in character, and in that condition totally valueless for the purpose of stuffing.

It was at this point that the inventor's skill was necessary. The pores of the sponge closed when the water had evaporated, and no permanent elasticity could be had unless these were held open permanently. Glycerin, being a non-evaporative substance, was found to answer the purpose. The remainder of the process is then as follows:-The dry hard sponge is placed in a solution of glycerin and water, in the proportion of about half and half, and after passing through heavy rollers it is again dried in the cylinders. The aqueous portion then evaporates, and leaves the bits of sponge dry and sweet, and so permeated with the glycerin that a permanent elasticity is maintained. It is then at last taken to the packing-room, highly compressed into bales of about $40 \mathrm{lbs}$. each, and is ready for market.

An enterprise was started in the United States in 1873 , for manufacturing the coarser sponges, sent as grass, glove, and refuse, into a sort of felting to be laid under carpets. Large quantities of these kinds were purchased, in the 


\section{I80 The Commercial Products of the Sea.}

Bahamas early in 1874 ; but the demand ceased in the latter part of the year, and the manufacture appears to have failed.

Persons may well be cautioned against buying cheap sponges from itinerant venders in the streets, which have probably done duty in hospitals, stables, or for other vile uses, and, even if they have been chemically washed and bleached, can scarcely be considered wholesome. Sponges which have been used in bathing wounds are liable to retain a disagreeable odour; while bacteria, monads, and various contaminating matters may be found in them. To obviate the evil, the infected sponge is impregnated with a solution of four parts of permanganate of potash to 100 parts of water; passing it next through a solution of sulphuric acid, and then washing with water. The sponge recovers its primitive state, and even its marine odour and the tissue is improved.

The Société d'Acclimatation of Paris, early in I862, sent out M. Lamiral to the coast of Syria, with a view to obtain sponges for transplantation. On his return, in September of that year, he presented a report. In this he distinguishes three kinds of sponges for which there is a demand-the fine and soft sponge, called abiand; the fine and hard sort, called achmar; and lastly, the common sort, called cabar by the Arabs. These sponges are found in the Levant within the 36 th and 33 rd degrees of latitude: that is, between Alexandretta and Saida.

It is now universally acknowledged that sponges belong to the animal kingdom, and are an aggregate of cellules built up by gelatinous polypi similar to those which construct madreporæ, porites, and other polypifers. When the sponge is first gathered at the bottom of the sea, it is covered with a black but transparent gelatinous substance, 
resembling vegetable granulations, among which microscopic white and oviform bodies may be distinguished. These are the larvæ destined to perpetuate the species. When arrived at maturity, they are washed out by the sea water which incessantly flows through the sponge; they then swim along, by the aid of the vibrating cilia or hairs with which they are provided, until they reach a suitable

FIG. 7 .

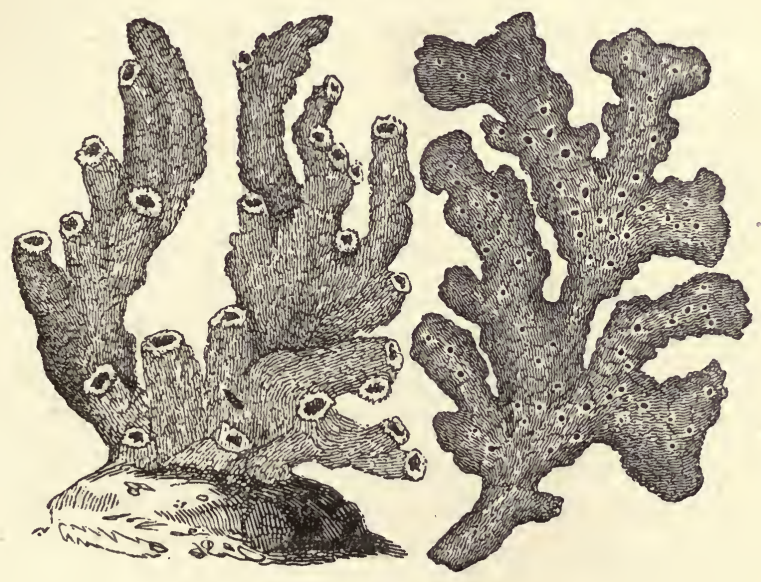

Sponges.

rock, to which they attach themselves, and there commence a new life. This emigration of the larvæ from the parent sponge occurs about the end of June and the beginning of July. The fine qualities of sponges are chiefly found at the depth of 15 fathoms or thereabout; the common sponge lies at depths varying between 20 and 30 fathoms.

At Tripoli (on the coast of Syria; not of Africa) M. Lamiral engaged some divers, who commenced operations on the 2 Ist of May. The sponges gathered were imme- 


\section{I32 The Commercial Products of the Sea.}

diately placed in boxes, through which a stream of sea water was constantly made to flow, the animal matter being, of course, left on them, and protected from injury. These sponges arrived at Marseilles on the $\mathrm{I} 7 \mathrm{th}$ of June; thence they were taken to Toulon and the islands of Hyères, where stone troughs, with five sponges in each, were sunk in different places.

During the past few years, Dr. Oscar Schmidt, Professor of Zoology at the University of Grätz, has employed several weeks of the early summer in artificially producing and rearing the bath sponge. His labours have met with such success that his system has been adopted by the Austrian Government, and is now carried on on the coast of Dalmatia.

It has for some time been a well-known fact that several families of zoophytes have such great powers of reproduction, that a portion of one will grow and form on an entire new body. This property has been taken advantage of by Dr. Schmidt, his process being to cut the sponge into pieces, fasten each portion to a pile, and immerse it in the sea. The pieces then grow, and eventually from each one a spherical sponge is obtained. According to the estimates of Dr. Schmidt, a small piece of sponge at the end of three years will represent a value of $5 d$. The total cost of raising 4000 sponges, including the interest on the expended capital for three years, is estimated at $£ 88 \mathrm{~s}$., and the income at about $£ \mathrm{I} \sigma$, leaving therefore a net profit of nearly $£ 8$. There is no doubt but that the practice of this branch of industry will be the means of considerable benefit to the inhabitants of the Idrian and Dalmatian coasts. 


\section{CHAPTER IV.}

SPONGE FISHERIES OF THE MEDITERRANEAN.

Sponge trade of the Ottoman Islands-Market prices of sponge-Number of boats employed-Fishing grounds on the coast of Candia, Syria, and Barbary-Statistics of the fisheries-Operation of diving-Diving-bells and dresses now used-Imports of sponge from the Mediterranean-Total imports of sponge into the United Kingdom-French trade in spongeSilicious sponges.

The Sponge Trade of the Ottoman Islands.-It appears that, with few exceptions, in which the owners of sponge boats have capital, all the funds required for the equipment of these boats are furnished by native money-lenders, and that important foreign capital, especially British and French, has latterly been invested in diving apparatus since the introduction of this new mode of fishing for sponges in these islands. It is noticeable, too, that a large French firm, whose operations in this trade were on a very extensive scale, have of late somewhat reduced their trade, while on the other hand the use of British-made machines continues to increase, and it is mentioned that there is a decided preference on the part of the natives to work with British rather than with French diving apparatus. The whole of the machines now employed in the Ottoman islands is upwards of 100 . Owing to the depressed prices 


\section{I84 The Commercial Products of the Sea.}

at which sponges have been sold during the last few years, and which have prevented divers from paying their debts to the native money-lenders, the latter, although in possession of bills for important sums of money, have not a sufficiency of cash to equip all the boats suitable for the sponge fishery. Notwithstanding the adverse circumstances, the quantity of sponges obtained of late has exceeded that of former years, in consequence of the more abundant crops and improved diving apparatus. At the island of Halki, for instance, where Io years ago the produce in sponges was hardly $£ 10,000$ a year, it amounts now, with the same number of boats, but working with diving apparatus, to nearly $£ 20,000$, thus showing a very important augmentation. It is mentioned, however, that the produce in sponges seems more than sufficient for the demand; and if all the available boats in these islands could procure the required money to enable them to go fishing, the extra quantities of sponges which would then encumber the markets would lower the price of the article to rates which would prove ruinous to the divers.

The average market prices of sponges for the year 1872 are shown per oke (equal to $2 \frac{3}{4} \mathrm{lbs}$.) in the subjoined table:-

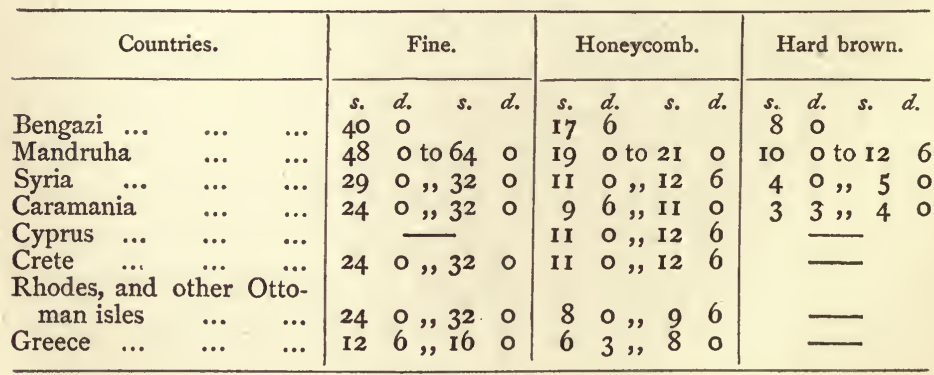

Bengazi and Mandruha sponges are not sold by weight; 


\section{Sponge Fisheries of the Mediterranean. $\quad$ I 85}

but by piece; for the sake of comparison, however, their prices are proportioned to others. Bengazi fine sponges are exceedingly scarce.

The prices quoted in the foregoing, although higher than those of the two preceding years, are still rather low, and Hellenic sponge boats, which used to bring and sell their crops in the markets of the Sporades, now abstain from doing so. In fact, owing to the reduced prices offered in these islands for sponges, several of the most enterprising native sponge-dealers decided, a few years ago, instead of selling their sponges in the local market, to convey them to Europe, and retail them on their own account from place to place. There is not a single country-even Sweden and Norway-which these sponge-dealers have not visited, in order to sell their goods. A few of them journeyed even as far as America; while some settled in London, where their countrymen ultimately bought the quantities which they had not been able to dispose of in their peregrinations. These attempts have been so far successful. It is stated that the value of sponges sent annually to Great Britain is no less than $£ 70,000$.

The principal article of export from the Ottoman Archipelago is sponge. The number of boats employed varies, ranging from 400 to 600 in the year. The latter number may be said to be thus distributed, as belonging to the different islands:-

$\begin{array}{lccccr}\text { Calmynos } & . . & \ldots & \ldots & \ldots & 254 \\ \text { Symi ... } & \ldots & \ldots & . . & \ldots & 190 \\ \text { Halki } & \ldots & \ldots & \ldots & \ldots & 65 \\ \text { Castel Rosso } & \ldots & \ldots & \ldots & \ldots & 40 \\ \text { Leros } & \ldots & \ldots & . . & \ldots & 30 \\ \text { Stampalia } & \ldots & \ldots & \ldots & \ldots & 12 \\ \text { Telos } & \ldots & \ldots & \ldots & . . & 7 \\ \text { Cassos } & \ldots & \ldots & \ldots & & . . \\ & & & & & 600\end{array}$




\section{I86 The Commercial Products of the Sea.}

As there are seven men to each boat, the number of men engaged is about 4200 .

The sponge fishing grounds are on the coast of Candia, Syria, and Barbary. The average depth at which sponges are found is 30 fathoms; those of an inferior quality are found at lesser depths. The sponge fishing-boats in the island of Calmynos amount to nearly 260 , employing 1600 men and boys. These boats, called "scafi," are on an average six tons each, carrying from six to seven, and sometimes eight men, of whom two are rowers.

The proceeds from the sponge obtained are divided into shares, the divers receiving a whole share, and the rowers two-thirds of a share. A good diver will make from eight to ten dives during the day.

The sponge is covered with a thin, tough, black cuticle, inside of which there is a white liquid like milk, and of the same consistence. The sponge in this state presents a very different appearance to what it does when freed from these extraneous substances. The annual value of the sponges taken by the Calymniotes amounts to about $£ 2500$. " The finest are sent to Great Britain ; the common and coarser to France, Austria, and Constantinople.

The sponge fishery of Turkey has made a great advance by the introduction of diving apparatus. The quality fished in the Sea of Marmora is of second-rate quality, and is shipped to England, and a part to Trieste and Germany.

The following shows the value in round numbers of the sponges sold at Rhodes in I86I:-Fine, $£ 4 \mathrm{I}, 000$; common, $£ 63,000$; coarse, $£ 7000$; total, £III,000. Part of the sponges fished in the autumn of 1860 were sold in the early part of I86I, at 450 piastres per oke for fine, 120 for common, and 60 for coarse, which are the highest ever reached for the fine and coarse qualities. Towards the 


\section{Sponge Fisheries of the Mediterranean. $\quad 187$}

Fig. 8.

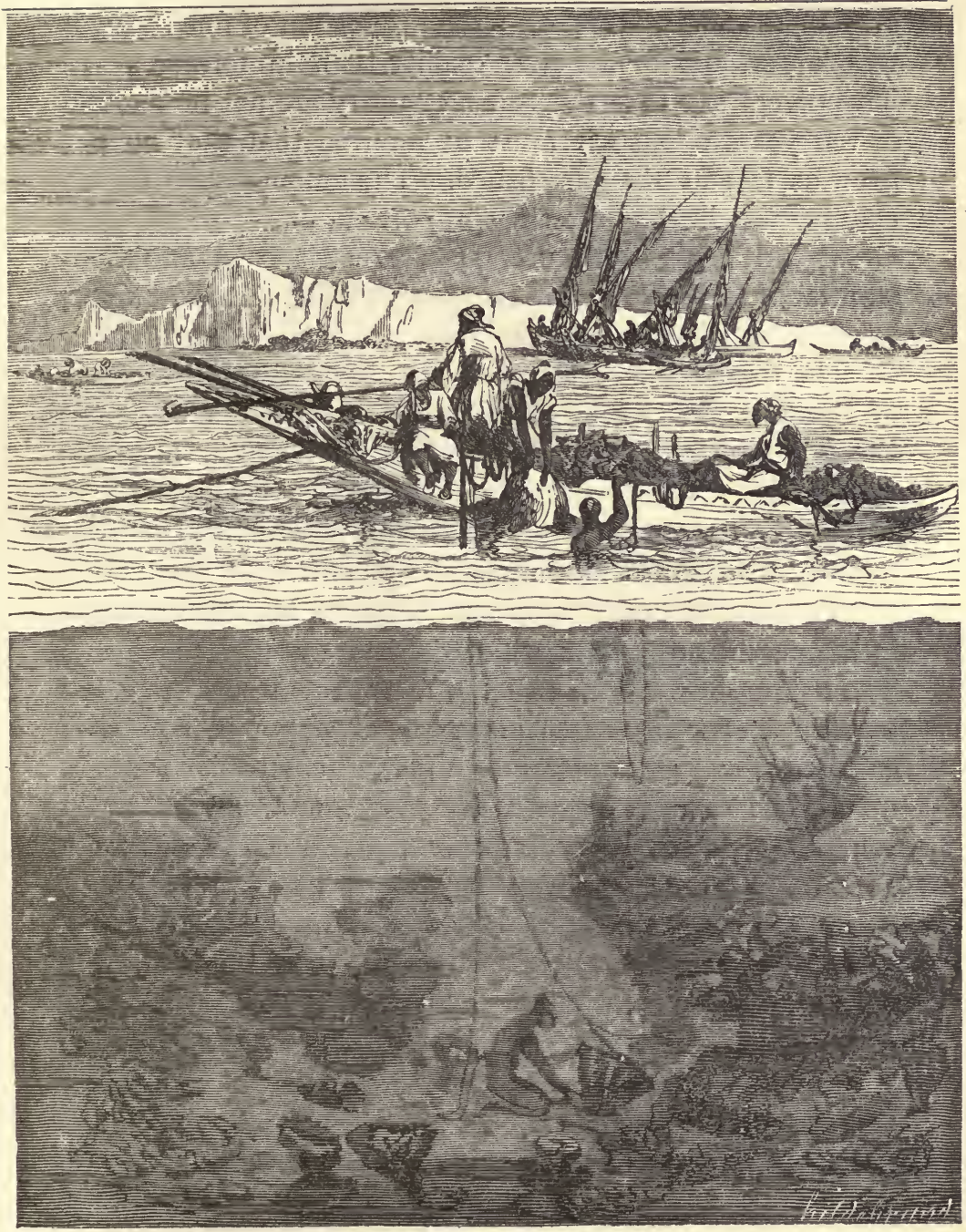

Syrian sponge fishers. 


\section{The Commercial Products of the Sea.}

end of the year, the prices declined nearly one-fourth. The crop of $\mathrm{I} 86 \mathrm{I}$ was abundant; the proportion of fine sponges was larger, and of a better quality than in former years. The divers say that the same quantity are not now found as ten years ago, so it must be inferred that they do not grow as fast as they are fished. The amount sent to each country was in the following proportion, out of 36 parts :Great Britain, 13 ; France, $15 \frac{1}{2}$; Austria, $5 \frac{1}{2}$; and Constantinople, 2 ; total, 36 . In I $86730 \mathrm{cwt}$., valued at $£ 700$, were exported from Turkey.

The total value of the sponges obtained on the coasts of Syria is $£ 20,000$ to $£ 25,000$, which seems to be about the average of past years. The production, however, appears to be falling off through excessive fishing. Some 250 to 300 boats are at present employed in this industry, manned by I 200 to I 500 men. The centres of production are Tripoli and Batronn on the coast of Mount Lebanon, in the neighbourhood of which the best qualities are found. The fishing-boats, from I 8 to 30 feet long, are each manned by a crew of four or five men, one of whom is especially engaged for the purpose of directing, while the rest are divers. The diver, naked of course, with an open net round his waist for holding the sponges, seizes with both hands an oblong white stone, to which is attached a rope, and plunges overboard. On arriving at the bottom, the stone is deposited at his feet, and the man, keeping hold of the rope with one hand, grasps and tears off with the other the sponges within reach, which he deposits in his net. $\mathrm{He}$ then, by a series of jerks to the rope, gives the signal to those above, and is drawn up. No knife, spear, or instrument of any kind is used. The depth to which the diver descends varies from 5 to 30 fathoms, each equal to an ordinary man's height. 
Although marked by a great variety of quality and size, sponges may be generally classified as the fine, white, bell-shaped "toilet sponge;" the large reddish variety, known as "éponge de venise" or "bath sponge ;" and the coarse red sponge, used for household purposes, cleaning, etc. France takes the bulk of the finest qualities, while the reddish and common sponges are sent to Germany and England.

The fisheries of the Lebanon employ I 20 boats, manned by 550 men. The annual yield varies in value between $£ 4000$ and $£ 6500$.

The value of sponges directly exported from the Sporades is about $£ 90,000$ additional. Formerly, almost the whole quantity of sponges was sent from the islands of the Sporades to Rhodes for transhipment to Europe; but since the English steamers call at those islands, sponges are sent direct.

On the coasts between the latitudes $32^{\circ} 20^{\prime}$ and $33^{\circ} 20^{\prime}$, the qualities of soft and hard, fine and venise sponges, are mixed and fished for together, at about the same depth, from 4 to $\mathrm{I} 5$ fathoms. Beyond this depth the venise sponge, which is mixed with the other two kinds only in the proportion of about one-third, is more abundant, and constitutes the bulk of the fishery. At a depth of 20 to 30 fathoms, this sponge, of a large size, is almost exclusively found. The prices paid have been-for bath or common sponges, according to quality, from 40 to 60 piastres per oke (equal to $2 \frac{3}{4} \mathrm{lbs}$.); fine sponges, from 120 to 200 piastres.

The sponges fished at Mandruha, on the coast of Africa, are always sold by the piece. The prices paid for them have been-bath sponges, from one and a half to four piastres a piece; fine sponges, from four to eight piastres a piece; 


\section{I90 The Commercial Products of the Sea.}

zimocca, or coarse sponges, from is to 18 paras a piece. In sponge transactions, the rate of the Turkish pound is I 5 piastres; and of the pound sterling, I 25 piastres. They still continue to send sanded sponges to England.

The sponges fished by diving apparatuses are not so good as those fished by neck-divers, these last going to deeper waters; the sponges there being of a superior quality. They therefore always cost from I 5 to 20 per cent. more than the former ones. Although the diving apparatuses secure a more abundant crop, they are getting unpopular, owing to the many accidents which are to be deplored every season, the divers using them exceeding the depth prescribed.

The total number of diving apparatuses imported from France and Great Britain during the last Io or I 2 years is about 250, but not more than I IO are actually at work. The gears for these machines, which are annually renewed, are generally imported from England. The total number of sponge fishing-boats (including also those with diving apparatuses) belonging to Rhodes and the Sporades Islands, is about 700, employing 6000 men. During the year 1874 , only 512 boats were sent to this fishery, of which 96 were supplied with diving apparatuses.

The sponge fishery in Tunis is most active in the months of December, January, and February, as, during the other seasons, the spot where the sponges are found is covered with dense masses of seaweed. The tempests of November and December clear away the latter, and allow the sponges to be seen. The fishery has, however, two seasons-one commencing in March and finishing in November; the other occupying the rest of the year. In the summer season the production is small, because diving apparatus is then necessary, and can only be employed 
where there is a rocky or other firm bottom; but the Arabs search along the coasts, feeling for the sponges with their feet beneath the masses of tangled weeds. The sponges which they find are generally of an inferior kind, as they cannot go into any depth of water. The success of the work of sponge-getting depends upon the sea being calm. There are not more than 40 or 50 days during the winter season which are favourable.

The Arabs who inhabit the coasts, the Greeks, and principally those of Kranidi, near Nauplia, and the Sicilians, all engage in the sponge fishing, but the Greeks are considered the most adroit and the Arabs the least so.

The gathering is performed by means of a trident, or "arth," a kind of dredge, similar to that used for taking oysters. The Arabs employ boats called "sandah," with crews of four to seven persons, one of whom only uses the harpoon. As soon as this man sees a sponge the boat is brought to a stand; the work is carried on to the depth of 15 to 35 feet. The Greeks, although very expert divers, also use the harpoon, but they employ small and very light boats, carrying only the harpooner and the sculler. The former explores the bottom of the sea by means of a kind of telescope-a tin tube about 14 inches in diameter and 20 inches long, with a thick glass at the lower end. The object of this tube is to get rid of the surface oscillations and allow the fisherman to see the bottom. The Greeks exhibit sometimes extraordinary dexterity in getting sponges from a depth of 60 feet with short harpoons ; they hold in their hands three or four harpoons, which they throw with such extraordinary rapidity and precision, that scarcely has one harpoon disappeared beneath the water, when the second strikes its upper end and adds to the force of the propulsion; the third is in 


\section{I92 The Commercial Products of the Sea.}

the same way struck into the second, and so on. Neither the Arabs nor the Sicilians avail themselves of either of the above methods of using the harpoon or of the wave tube.

The sponge fishery is considered to be capable of great development, and the danger of exhausting the supply is not great, as a new sponge is said to take the place of one removed within twelve months.

The following table shows the imports of Turkey and Mediterranean sponges into the United Kingdom for a series of years :-

\begin{tabular}{|c|c|c|c|c|c|c|}
\hline 1851 & $\ldots$ & $\ldots$ & $\begin{array}{l}\text { lbs. } \\
\mathbf{1} 89,8 \mathbf{2} 8\end{array}$ & $\ldots$ & $\ldots$ & Value. \\
\hline 8 & $\ldots$ & $\cdots$ & 160,621 & $\ldots$ & $\ldots$ & \\
\hline 353 & $\ldots$ & $\ldots$ & 205,924 & $\ldots$ & $\ldots$ & - \\
\hline & $\ldots$ & $\ldots$ & 224,787 & $\ldots$ & $\ldots$ & $£ 70,246$ \\
\hline & $\ldots$ & $\ldots$ & 339,985 & $\ldots$ & $\ldots$ & 140,164 \\
\hline & $\ldots$ & $\cdots$ & 313,287 & ... & $\ldots$ & 172,308 \\
\hline & ... & $\ldots$ & $3 \mathrm{I} 8,676$ & $\ldots$ & $\ldots$ & 164,650 \\
\hline & $\ldots$ & $\ldots$ & $287,68 \mathrm{I}$ & $\ldots$ & $\ldots$ & $\mathrm{I} 57,75^{\mathrm{I}}$ \\
\hline 59 & $\cdots$ & $\ldots$ & 345,818 & $\ldots$ & $\ldots$ & 218,161 \\
\hline & $\ldots$ & $\cdots$ & $4 \mathrm{II}, \mathrm{III}$ & $\ldots$ & $\ldots$ & 270,410 \\
\hline & $\ldots$ & $\ldots$ & 340,506 & $\ldots$ & $\ldots$ & 108,782 \\
\hline & $\ldots$ & $\ldots$ & 348,924 & $\ldots$ & $\ldots$ & 74,833 \\
\hline 802 & $\ldots$ & $\ldots$ & 377, I I I & $\ldots$ & $\ldots$ & 69,074 \\
\hline & $\ldots$ & $\ldots$ & 431,906 & $\ldots$ & $\ldots$ & 53,168 \\
\hline & $\cdots$ & $\cdots$ & $3^{21,199}$ & $\ldots$ & $\ldots$ & $4 \mathrm{I}, 477$ \\
\hline & $\cdots$ & $\ldots$ & 320,032 & ... & $\ldots$ & $3^{1}, 415$ \\
\hline & $\ldots$ & $\ldots$ & 356,131 & $\ldots$ & $\ldots$ & $6 \mathrm{I}, 8 \mathrm{I} 7$ \\
\hline & $\ldots$ & ... & 660,685 & ... & $\ldots$ & $85,75 \mathrm{r}$ \\
\hline & $\ldots$ & $\ldots$ & 453,819 & $\ldots$ & $\ldots$ & II 3,384 \\
\hline
\end{tabular}

The imports have not been officially recorded since.

The supplies are received principally through the four channels of France, Greece, Turkey proper, Italy, and sometimes from Malta and Egypt.

The sponges shipped are of three qualities-fine, common, and coarse. In the fine qualities there is but one in ten of the first or superior quality; the rest are of a second or 
inferior fine quality. Of the common sponges there is one in four of a first quality; the rest are of a second or common quality. Of the coarse, one-half are of a first quality, and the other half of a second quality. Thus, it will be seen that the fine, common, and coarse kinds of sponges may be divided into two qualities each.

The total imports of sponge into Great Britain in 1840 were $78,500 \mathrm{lbs}$. ; in $\mathrm{I} 84 \mathrm{I}, 58,93 \mathrm{I}$ lbs. ; in $\mathrm{I} 855,47 \mathrm{I}, 87 \mathrm{I} \mathrm{lbs}$. The quantity and value of the imports of sponge into the United Kingdom since have been as follows :-

\begin{tabular}{rrrrrrrr} 
& & \multicolumn{3}{c}{$\begin{array}{c}\text { Quantity. } \\
\text { lbs. }\end{array}$} & & \multicolumn{2}{c}{ Computed value. } \\
$\mathbf{1} 862$ & $\ldots$ & $\ldots$ & 544,882 & $\ldots$ & $\ldots$ & $£ 100,204$ \\
$\mathbf{1} 863$ & $\ldots$ & $\ldots$ & 474,748 & $\ldots$ & $\ldots$ & 77,907 \\
1864 & $\ldots$ & $\ldots$ & 540,172 & $\ldots$ & $\ldots$ & 60,278 \\
$\mathbf{1} 865$ & $\ldots$ & $\ldots$ & 694,128 & $\ldots$ & $\ldots$ & 103,780 \\
1866 & $\ldots$ & $\ldots$ & 895,369 & $\ldots$ & $\ldots$ & 96,768 \\
1867 & $\ldots$ & $\ldots$ & 980,259 & $\ldots$ & $\ldots$ & 86,201 \\
1868 & $\ldots$ & $\ldots$ & 997,447 & $\ldots$ & $\ldots$ & 119,917 \\
1869 & $\ldots$ & $\ldots$ & $1,221,673$ & $\ldots$ & $\ldots$ & 156,965 \\
1870 & $\ldots$ & $\ldots$ & 837,159 & $\ldots$ & $\ldots$ & 160,162
\end{tabular}

No return published since.

The following is the French classification of commercial sponges :-

Fine soft Syrian.

, Archipelago.

Fine hard, of Syria, known as Chimousse.

Yellow sponge of Syria, known as fine venise.

of the Archipelago, known as common venise.

Hen sponge of Barbary.

Brown sponge of Barbary, called Marseilles.

Salonica sponge.

Lastly, the Bahamas and American sponges, which are divided into fine and common. Their tissue is loose, without elasticity, and hence they are easily torn. They sell at a low price.

In the ten years ending 1860 , the sale of sponge in 
I94 The Commercial Products of the Sea.

France was 2,000,000 kilogrammes, of the value of $10,600,000$ francs $(£ 424,000)$. The consumption is therefore about 150,000 kilogrammes per annum. There was imported into France in I875 246,666 kilogrammes of

FIG. 9 .

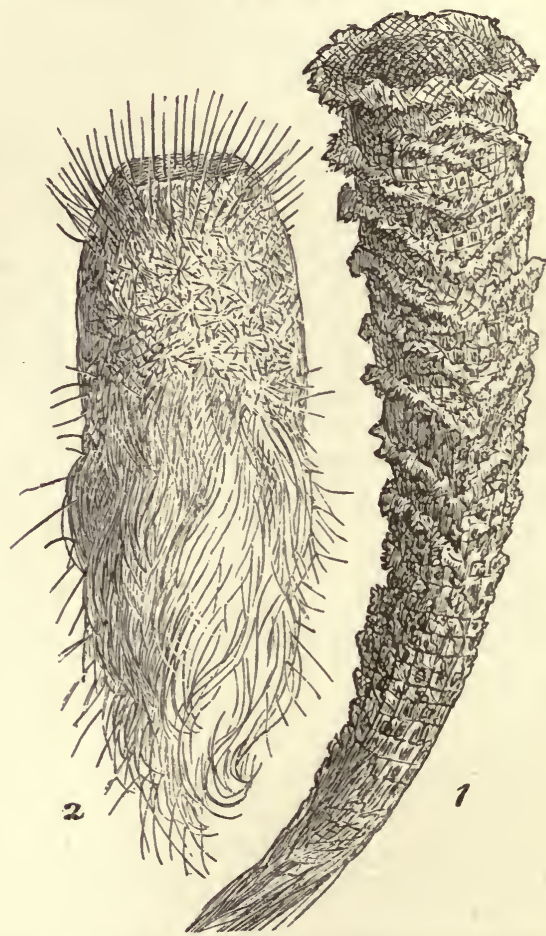

Silicious sponges. I. Euplectella aspergillum; 2. Holtenia carpenteria.

sponge, of which 93,324 kilogrammes were re-exported. In 1876 the imports reached 257,878 kilogrammes, and the exports were 89,600 kilogrammes.

Silicious Sponges.-Sponges are not confined to recent 


\section{Sponge Fisheries of the Mediterranean. 195}

seas, though the commercial ones are not known to have existed earlier, because the keratose matter furnishes hardly favourable conditions for petrifaction. In the oölite and chalk formations, sponges containing flinty spicules were very abundant; and in most of the earlier formations, large sponges containing calcareous spicules abounded. These very closely resemble corals, and have been mistaken for them by some of our best geologists. The spiculæ or needle-shaped particles, which are often microscopic in size, are not thrown in without order, but are arranged to support the skeleton. The horny sponges do not secrete or cleposit spicules, but these are sometimes found within the skeleton in broken and disordered form, which show they were taken in from without.

The quantity of silica which constitutes the structure of sponges is remarkable. It generally occurs in the form of spiculæ in considerable quantities, imbedded in the substance or body of the sponge. One of the rarest and most beautiful of the silicious sponges is the Euplectella speciosa, found at the Philippine Islands. It is of cornucopia shape, and has a horny, skeleton-like network, composed of large silicious fibres running from the base to the head, surrounded by small fibres forming square, open meshes, resembling a net or basket work. It ranges in height from 6 to over 15 inches. At the lower extremity, or root, it averages about an inch in thickness, but its size gradually increases as it approaches the top, where often it is two inches wide. It is surmounted by a ridge about a quarter of an inch wide, and is closed at the larger extremity by a delicate open lacework of fibres, possessing no particular pattern. It is on this light and pretty. structure that the fibrous, gelatinous substance rests, resembling in texture the common sponge, but in this instance disposed in an 


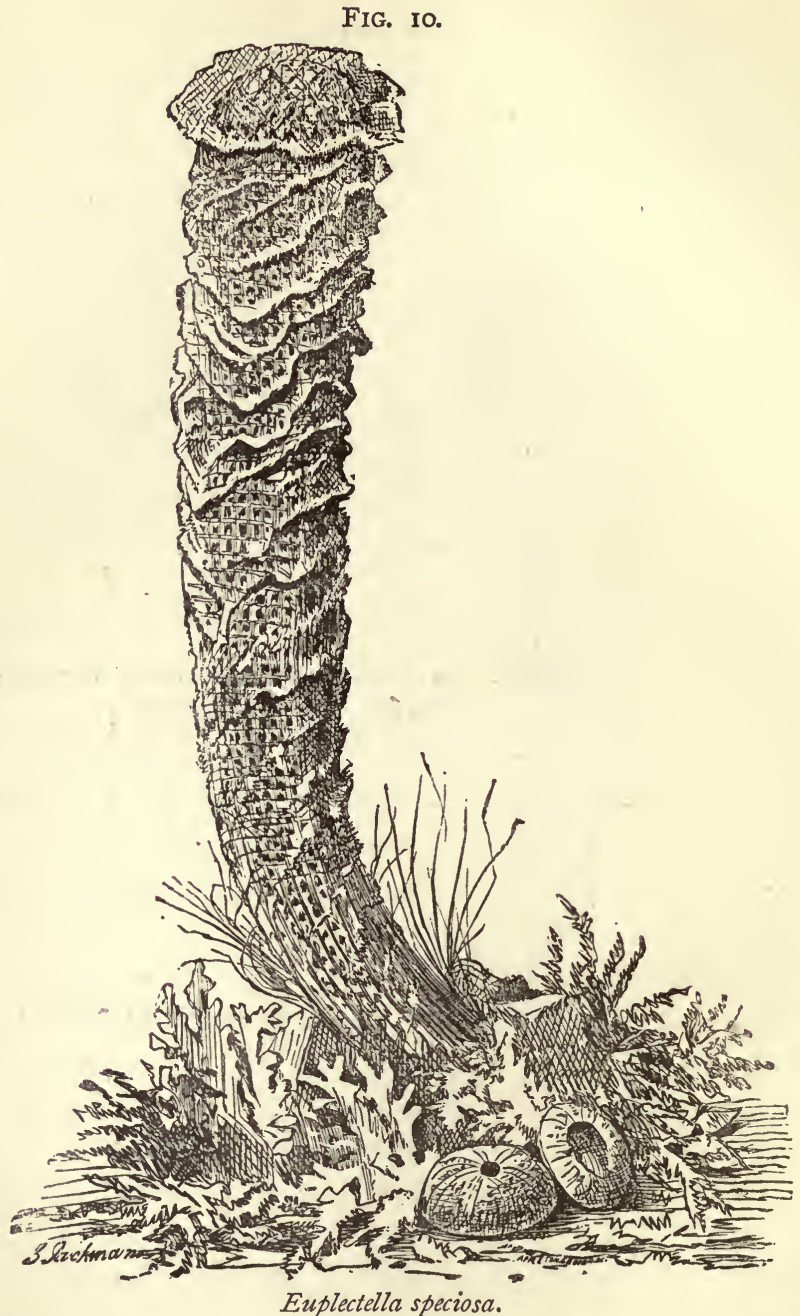

irregular, foliated pattern, over which the usual film of the sponge is laid during life.*

* Bryce M. Wright in "The American Naturalist." 
Sponge Fisheries of the Mediterranean. $\quad 197$

At one time this sponge was so rare that specimens fetched enormous prices; now, by the progress of commerce, it has become more common, and specimens of great beauty may be had for a few shillings.

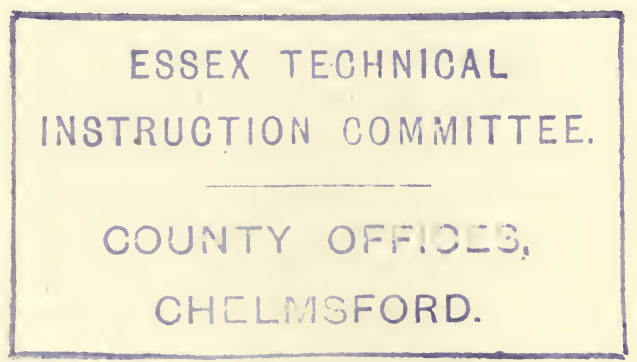


198 The Commercial Products of the Sea.

\section{CHAPTER V.}

\section{OILS FROM MARINE MAMMALS.}

The seal fishery-Seal oil-Yield of oil from blubber-Seal-skins-The fur seal-The walrus-The whale fishery-Imports of train oil or blubber, spermaceti, and whalebone-Porpoise oil-Dugong oil.

Oils from the Mammals.-One of the articles contributed by marine animals to the wants of industry is oil; which is largely obtained both from mammals and fishes. The aggregate value of the trade in these in the United Kingdom alone exceeds $£ \mathrm{I}, 000,000$ sterling a year. Some of these oleaginous substances are employed as food by man, some in manufactures, and others in medicine.

Oil for commercial purposes is obtained in greater or less quantities from numerous inhabitants of the seasfrom the marine mammals, the right and spermaceti whale, the seal, sea-elephant, dugong, porpoise, etc. ; from the shark, sunfish, cod, herring, and numerous small fish, which are especially sought for the oil they yield.

The great trade in animal oils and fatty substances indicates the care with which oily matters, rich in carbon and hydrogen, are sought in all countries, supplying as they do a great number of wants in countries the most civilized, as well as among people still in their primitive state. We know that fish oils are beneficial in consumptive cases, as 


\section{Oils from Marine Mammals.}

with cod-liver oil and that obtained from the dugong; but they might be often used with advantage for inunction, where they are not easily retained on the stomach.

Dr. T. Thompson has pointed out the medicinal value of various animal oils besides cod-liver oil, such as sperm and seal oil ; and the result of his observations was a conviction that fish oils generally resembled one another in their remedial properties, although differing in their aptitude for digestive assimilation in the human stomach. He tried neat's-foot oil, an animal oil obtained from a soft, solid fat found between the parchment and the leather skin of animals; also shark-liver oil, and an oil obtained from a species of fish abounding on the Malabar coast ; and these trials were frequently attended with encouraging results.

The practice of daily inunction is common in many warm countries, and serves to soften the skin and keep the body in health. In tropical regions, vegetable oils are chiefly used ; but the New Zealanders and some others use shark oil. The Esquimaux and Greenlanders imbibe large quantities of train, seal, and various fish oils; whilst the natives about the large rivers and coasts of Brazil use turtle oil, and fat obtained from the alligator and crocodile. The natives of many parts of India use shark oil and that from the liver of the sword-fish in anointing their skin.

Those who are employed in the woollen trade, and in soap, candle, and other factories, where oil and fats are largely used, enjoy a comparative immunity from scrofula and phthisis. Sailors believe a whaling voyage to be a cure for consumption; and probably the quantity of oil drunk and taken into the skin may have its beneficial effect upon the system.

The Seal Fishery.-After the cod fishery, the seal fishery is the most profitable branch of trade in New- 
foundland. More than 350 vessels are engaged in it. The seals whelp their young in January and February on the ice field of Labrador; this ice is floated southwards by the ocean currents, and is always to be found on the coast of Newfoundland after the middle of March. The take of seals varies; in some years the export of skins being under 200,000 , in others exceeding 450,000 . The value of the seal oil shipped ranges from $£ 160,000$ to $£ 200,000$. The yield of oil is about I I gallons from one cwt. of blubber.

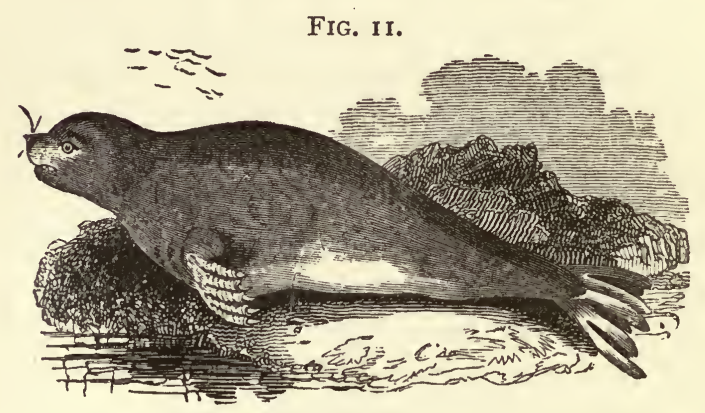

Phoca Groenlandica.

Seal oil and cod oil are now two of the most important, whale oil having much declined in quantity, owing to the fishery being less earnestly prosecuted; but there are very many fish oils, extracted in different quarters, which have a local and general use, such as shark oil, herring oil, menhaden oil, etc.

Seal Oil.-There are three classifications of seal oil: that which drains spontaneously by the pressure of the layers of the skins one over the other; that which is prepared by submitting the fat to the action of steam in hermetically closed boilers; and that which is obtained from the residual mass, submitted to a high pressure. 
At St. John's, Newfoundland, the head-quarters of the sealing trade, the blubber used to be generally put into wooden cribs, beneath which were wooden pans to catch the oil. No artificial heat was used in this process. The oil which runs for the first two or three months is termed pale seal oil, and forms 50 to 70 per cent. of the whole quantity. As putrefaction takes place, the oil becomes darker and more offensive. The putrescent refuse and the clippings of the pelts, or skins, yield further quantities of oil by boiling (boiled seal oil). This process is now very generally replaced by steam apparatus. A uniform and much better quality of oil is thus obtained, free from the horrible odour of that prepared by the old method, and the time required for rendering out the oil is only twelve hours, instead of six months. A few drops of nitric ether is said to destroy the disagreeable smell of rancid oil, and to prevent oil becoming rancid. When the oil is heated to separate the alcohol, it becomes clear and bright, even when it was before turbid.

In Russia a quantity of seal oil is obtained annually in the White and Caspian Seas. The mode of preparation is very simple. After removing the layer of blubber which adheres to the skin, it is exposed in casks or vats to the heat of the sun, which dissolves out the oil of first quality. The residue is heafed in cauldrons with a little water. In one or two factories the preparation of the oil on a large scale is carried on by steam. The seals killed in autumn and winter have the oil rendered out forthwith, without the necessity of first salting the skins; but in the hot seasons this step is necessary, and a great pit is prepared, capable of holding 50,000 skins.

Repeated and careful experiments in rendering out seal blubber show the relative produce of pure oil obtained from 
202 The Commercial Products of the Sea.

the different species to be as follows for one barrel of blubber, from seals in prime condition :-

\begin{tabular}{ll|l|c|c}
\hline & & Barrels of fat. & Oil. & Residue. \\
\hline & & lbs. & Galls. & Ibs. \\
Old harp (Phoca Groenlandica) & $\ldots$ & 288 & $22 \frac{1}{2}$ & 73 \\
Young harp $\quad \ldots .$. & $\ldots$ & 225 & 22 & 52 \\
Young hood (Stemmatopus cristatus) & $\ldots$ & 230 & $2 \mathrm{I}$ & 80 \\
Beadlemer (a year-old hood) & $\ldots$ & 246 & 2 I & IO3 \\
\hline
\end{tabular}

In 1850 the export of seal oil from Newfoundland was 6200 tuns, valued at $£ 180,000$; in 1860 it was 5565 tuns, valued at $£ \mathrm{I} 69,975$; in $\mathrm{I} 870$ it was 4982 tuns, valued at $£ 176,472$; and in 1875,4837 tuns, valued at $£ \mathrm{r} 32, \mathrm{I} 16$.

The total value of the oil shipped from Newfoundland has been as below :-

\begin{tabular}{|c|c|c|c|c|c|}
\hline \multirow{2}{*}{ Cod oil $\ldots$} & & 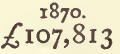 & $\cdots$ & & $\begin{array}{l}\text { r875. } \\
6101,420\end{array}$ \\
\hline & $\ldots$ & 21,068 & $\ldots$ & ... & 3,842 \\
\hline Seal oil $\quad \ldots$ & $\ldots$ & 176,472 & $\ldots$ & $\ldots$ & 132,116 \\
\hline & & & & & \\
\hline
\end{tabular}

Thirty small sloops and steam vessels were employed on the bank and Spitzbergen fisheries in 1873 ; the catch resulted in 130,000 seals, 350 sea-horses or walruses, and 6363 barrels of liver, estimated together at a value of $£ 99,669$.

Seal-skins.-The seal fishery is chiefly prosecuted from Newfoundland. It commences in March, and rarely lasts longer than one or two months. There are from I 50 to 200 decked vessels employed in it. These will take probably 2000 each, but as many as 8000 have been taken on a single trip, and often two or three voyages are made in one season.

The quantity of seal-skins received in this country varies; it has been as low as 160,000 , and as high as 


\section{Oils from Marine Mammals.}

876,000 . In the last quarter of a century the total number received has been nearly $23,000,000$, thus summarized in periods of nine years ending-

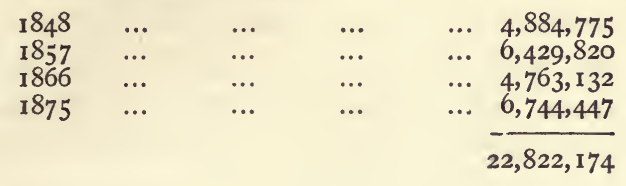

FIG. 12.

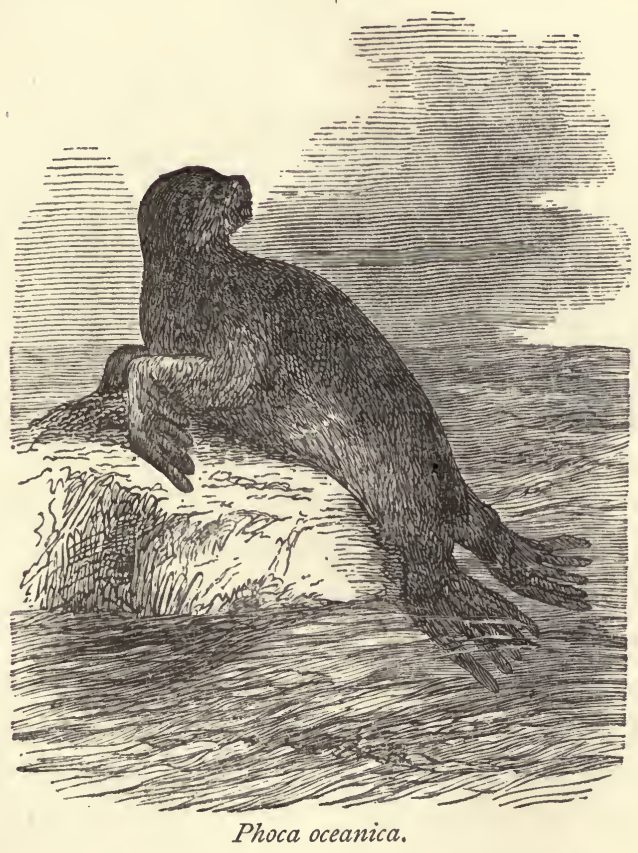

The fur seal-skin of commerce is obtained from different animals to those of the hair seals. One association, the Alaska Company, contributes 100,000 of these skins a year, having a monopoly by a contract with the American Government. 
Having fully described and figured the marine mammalia of any commercial value in another work,* I would refer those desirous of further details to it.

The walrus (Trichecus rosmarus) furnishes some economic products, in its flesh, its skin, its teeth, and the oil obtained from the blubber. The inhabitants of the Arctic regions esteem its flesh. The hide, when cut into shreds and plaited into cordage, forms lines used in cap-

\section{FIG. I3.}

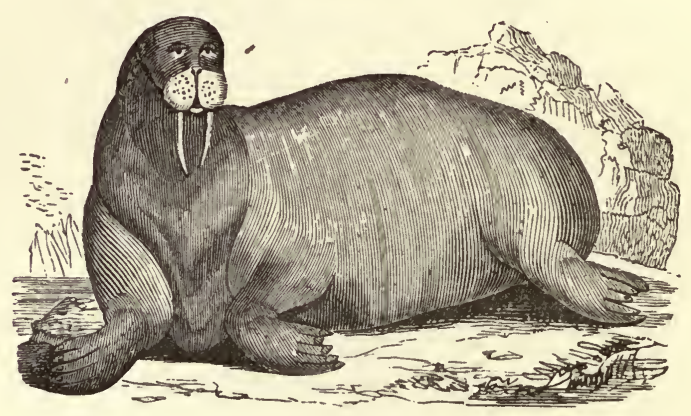

Walrus.

turing the whale. It has also been successfully used for belting and for covering skin-boats. The quantity of walrus tusks obtained in Alaska averages 100,000 lbs. in weight. The teeth, which weigh about four pounds the pair, used to be in great demand by dentists. Among the Chinese this dentine is employed for those various uses to which they turn ivory so skilfully. Walrus oil is a wellknown article of commerce.

The Whale Fishery.-Narratives and accounts have so frequently and graphically been written, that it is not

* "Animal Products : their Preparation, Commercial Uses, and Value." Chapman and Hall, 1877. 
necessary to enter into any lengthened detail here of the prosecution of this fishery, which has largely declined, having been much abandoned, as compared with former years, both by the English and Americans. The French have given it up altogether.

A quarter of a century ago, 730 ships, registering 233,1 89 tons, were employed in the American whale fishery; now there are less than I70 vessels, registering 40,000 tons, employed in whaling.

The extensive use of gas, as well as the employment of mineral and vegetable oils, for illuminating purposes, has in a great degree superseded the demand for whale oil that existed half a century ago. Our annual average imports of train oil, it will be seen, keep pretty steady.

IMPORTS INTO THE UNITED KINGDOM.

\begin{tabular}{|c|c|c|c|c|}
\hline & \multicolumn{2}{|c|}{ Train oil or blubber. } & \multicolumn{2}{|c|}{ Spermaceti or head matter. } \\
\hline I 867 & $\begin{array}{l}\text { Tuns. } \\
\text { I I } 90 \text { I }\end{array}$ & $\begin{array}{c}\text { Value. } \\
\{478,723\end{array}$ & $\begin{array}{l}\text { Tuns. } \\
3226\end{array}$ & $\begin{array}{l}\text { Value. } \\
\end{array}$ \\
\hline I 868 & I I, 203 & 415,400 & I945 & I 85,960 \\
\hline I 869 & 10,146 & 399,536 & 4IO7 & $387, \mathrm{I} 7 \mathrm{I}$ \\
\hline 1870 & 14,721 & 549,213 & 4069 & $34 \mathrm{I}, 340$ \\
\hline I87I & $19,29 \mathrm{I}$ & 636,706 & 5388 & 451,028 \\
\hline 1872 & $\mathrm{r} 5, \mathrm{co}+$ & 522,056 & 3715 & 333,534 \\
\hline 1873 & 15,069 & 514,493 & 2817 & 252,434 \\
\hline I874 & 13,896 & 454,729 & 3155 & 296,630 \\
\hline $1875^{\circ}$ & 14,890 & 489,8 I 7 & 4469 & 427,884 \\
\hline 1876 & 13,466 & 445,262 & 3218 & 230,359 \\
\hline
\end{tabular}

The blubber on a fat whale is sometimes, in its thickest parts, from 15 to 20 inches thick, though usually not more than a foot; it is of a coarse texture, and much harder than pork. So very full of oil is it, that a cask closely packed with the clean raw fat of the whale will not contain the oil boiled from it and the scraps that are left besides. 
Whalebone, as it is erroneously termed, is another valuable product of this fishery.

FIG. I4.

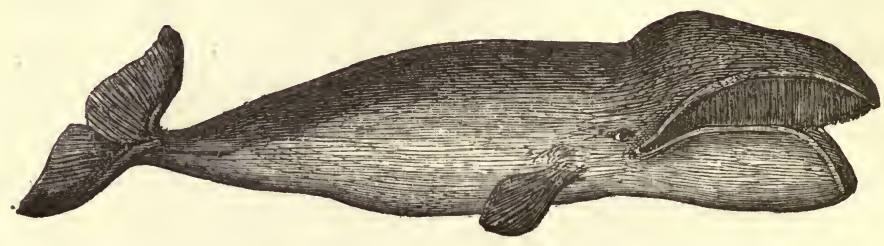

1

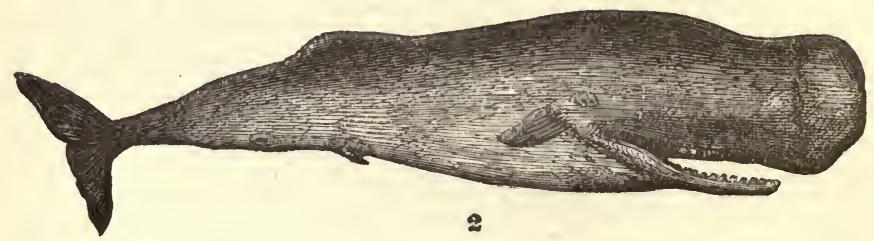

I. Greenland or right whale ; 2. Spermaceti whale.

The whale-fins imported into the United Kingdom in the last ten years have been as follows :-

$\begin{array}{rrrrrrrr}1867 & \ldots & \ldots & 2740 & \ldots & & \ldots & £ 51,286 \\ 1868 & \ldots & \ldots & 3800 & \ldots & & \ldots & 67,876 \\ 1869 & \ldots & \ldots & 1680 & \ldots & & \ldots & 34,958 \\ 1870 & \ldots & \ldots & 4260 & \ldots & \ldots & 79,482 \\ 1871 & \ldots & \ldots & 2853 & \ldots & \ldots & 45,178 \\ 1872 & \ldots & \ldots & 2831 & \ldots & \ldots & 51,558 \\ 1873 & \ldots & \ldots & 3544 & \ldots & \ldots & 64,618 \\ 1874 & \ldots & \ldots & 2911 & \ldots & \ldots & 54,920 \\ 1875 & \ldots & \ldots & 1871 & \ldots & \ldots & 42,240 \\ 1876 & \ldots & \ldots & 1799 & \ldots & \ldots & 47,144\end{array}$

A flourishing establishment has grown up in the vicinity of the small town of Vadsó, at the entrance of the Waranger Fiord, Norway, under the auspices of a Mr. Foyn, 


\section{Oils from Marine Mammals.}

of Tónsberg, the patentee of an improved kind of harpoon employed in the whale fishery. It consists of a harpoon with two movable barbs like the claws of an anchor, one on each side. The harpoon is projected from a swivel gun fixed on the bows of the vessel. The claws or barbs lie flat against the stem while in the gun, and during its progress through the air and entrance into the body of the fish; but no sooner is the line attached to the harpoon hauled upon, or the fish takes a start, than the claws or barbs expand and become fixed at an angle of $45^{\circ}$ on each side, which effectually precludes the possibility of the harpoon being withdrawn from the body of the fish. In addition to this, a capsule containing an explosive substance is concealed in the harpoon, which by another ingenious contrivance explodes, causing instant death. The animal is then towed by the steamer to the factory, where the usual flenching process commences; and as soon as completed, the residue of the huge animal is converted into artificial manure (guano), by which the whole carcase becomes utilized. Mr. Foyn employs two small steamers, and in 1873 caught 38 whales. From the effective means employed, it appears that he never loses a whale after the harpoon has once entered the carcase, the struggle seldom lasting above a few minutes after the fish is struck before death ensues. The factory is situated at the entrance to the Waranger Fiord, where the process of utilization commences. This species differs from the Greenland whale (Balcenoptera), and when full grown exceeds it in size, as they have been caught roo feet in length, and the young when cast have been known to reach 20 feet. In $1874 \mathrm{Mr}$. Foyn is reported to have caught 50 whales, which were estimated to be worth from $£$ I 50 sterling each. 
Porpoise Oil.-A fishery for the porpoise (Delphimus phocana) is carried on off the coasts of Trebizond; it is FIG. 15 .

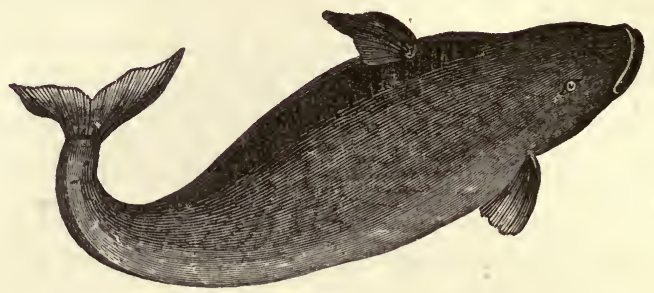

Black porpoise (Phocana vulgaris).

taken in nets, and also shot. This fishery yields upwards of $700,000 \mathrm{lbs}$. of oil per annum, a portion of which is consumed by the lower classes for lighting, and the rest finds a market in Constantinople. Porpoises are also caught in large numbers in the Little Belt, Denmark, where I 500 to 2000 are frequently obtained.

The extraction of the oil of the white whale (Beluga

FIG. I6.

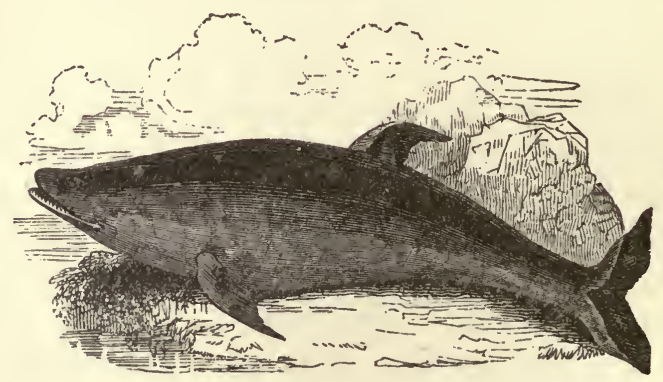

Grampus (Phorana orca).

catodon) and of the black porpoise constitutes an important industry in the district of Quebec, on the St. Lawrence 
river. This oil is inodorous, and gives a brilliant light. It is said to be superior to any other for lighthouses, because it does not coagulate even in the most intense cold, and its durability renders it invaluable for greasing leather and oiling machinery, which it preserves from injury by friction.

In I874 fish oil to the value of $£ 86,600$ was exported from Canada.

Dugong Oil.-An animal oil, having medicinal properties, was a few years ago added to the list of commercial products. It is obtained from the blubber of the dugong of Australia (Halicore Australis), a native of the shores of Queensland and the north-west coast of Australia. It was recommended as a new therapeutic agent, and as a substitute for cod-liver oil. The distinction between them is that the dugong oil contains no iodine ; it is said, however, to possess all the advantages of the cod-liver oil without its unpleasant smell. No large supply of this oil could, however, be obtained, and from having arrived frequently much adulterated it lost any reputation it may have merited.

The best known of this family is the Manatus Americanus, Cuv., which frequents the mouths of rivers, and quiet, secluded bays and inlets, in the islands of the West Indies and the coasts of Guinea and Brazil. It is said to attain nearly 20 feet in length, and differs from the dugong in having no canines or incisors. An old author, Dr. R. Brookes, in his "Natural History," speaking of it says, "The fat which lies between the cuticle and the skin, when exposed to the sun, has a fine smell and taste, and far exceeds the fat of any sea animal. It has this peculiar property, that the heat of the sun will not spoil it, nor make it grow rancid. The taste is like the oil of sweet almonds, and it will serve very well in all cases instead of butter. Any quantity may be taken. inwardly with safety, 
for it has no other effect than keeping the body open. The fat of the tail is of a harder consistence, and when boiled is more delicate than the other." The flesh of the manatus is highly esteemed as food in all countries the shores of which it frequents. It is particularly abundant in the

\section{FIG. I7.}
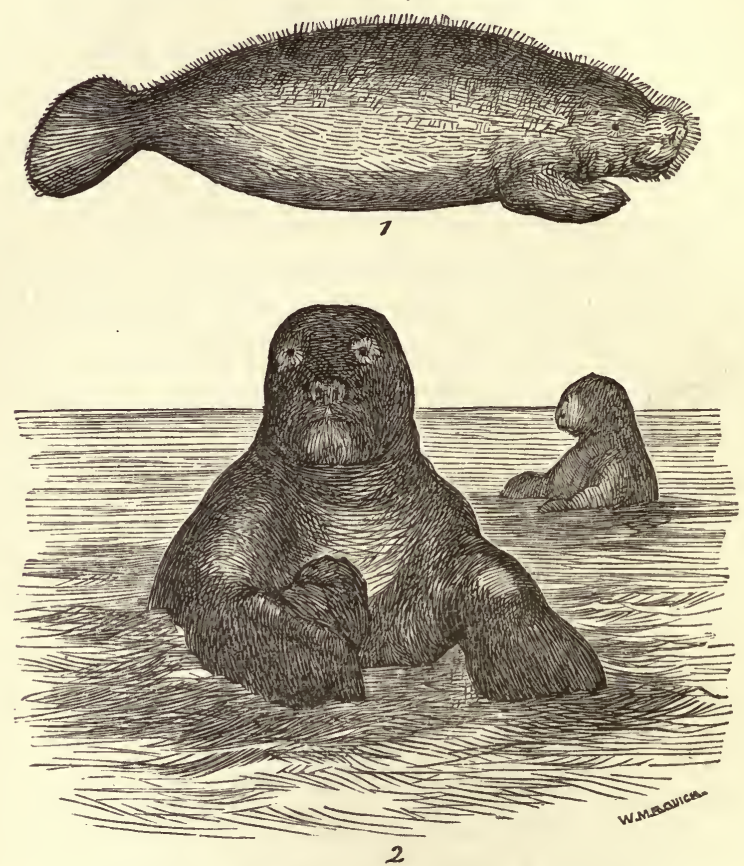

1. Halicore Australss; 2. Manatus Americanus.

lakes of the Amazon. Wallace, in his Travels up that river, describes it. "Beneath the skin," he says, "is a layer of fat of a greater or less thickness, generally about an inch, which is boiled down to make an oil used for lighting and cooking. Each animal yields from 5 to 25 gallons of oil." 
Edwards, in his "Voyage up the River Amazon," speaks of them, and says, not unfrequently they are taken eight feet in length. This is said to be a distinct species from the Manatus of the Gulf of Mexico. 


\section{CHAPTER VI.}

FISH OILS AND THE FISHERIES CONNECTED THEREWITH.

Definition of fish oil-Cod oil-Cod-liver oil-Exports from NewfoundlandMode of preparation-Exports from Norway-From Iceland-Fish oils in Russia-Indian fish oils-Fishes from which obtained-Tunny oilHerring oil-Oolachan oil-Menhaden oil-Mode of preparation and statistics.

THE term fish oil is a very vague one, from its being generally applied to oil of all kinds, obtained both from marine mammals and fishes. Train oil from the whale is frequently so termed. Shark oil, and the oil expressed or obtained by heat from various kinds of fish, large and small, is very much mixed as sent into commerce, and it is scarcely possible, unless from a few special districts and large factories, to know what is the true source of the fish oil purchased. There are some few large fisheries, such as the cod, herring, pilchard, sardine, menhaden, etc., where attention is given to the preparation of the oil.

Cod Oil.-The oil obtained from the cod forms a considerable item in the fishing business. About one hogshead of oil is produced from every five tons of fish. The quantity of oil extracted from cod livers in Newfoundland is about $1,250,000$ gallons, valued at $£ 200,000$. Nearly all 


\section{Fish Oils and the Fisheries connected therewith. 2 I 3}

is sent to England, as the American import duty is so high. The value of the crude cod oil shipped from Newfoundland amounts to about $£ \mathrm{II} 0,000$, and of the refined cod oil from $£ 10,000$ to $£ \mathrm{I} 5,000$. The export of cod oil from the French Newfoundland fisheries in the five years ending I87 I averaged 560,000 kilogrammes. In 1876, 2,819,000 kilogrammes of fish oil were imported into Havre.

The medicinal qualities of cod-liver oil have long been fully proved, and its manufacture has been a great source of wealth to the fishing colony of Newfoundland. Like all good things, however, it is easily imitated. The common cod oil, made by the putrifying process, has often been refined by animal charcoal, filtered so as to deprive it of all bad smell (the iodine and all other medicinal qualities having passed away by putrefaction in the manufacture), and it is then palmed off by dishonest dealers as the genuine article.

The cod livers reserved for the preparation of medicinal oil are all very carefully examined, and those that are poor, have sustained injury, or have portions of gall adhering, are removed. The selected livers are then thoroughly washed and afterwards dried. The fishermen-many of whom make the oil themselves, or sell to larger makers-put these prepared livers immediately into open barrels, where the oil slowly exudes, and, rising to the top, is removed with large spoons. It is, when quite cold, filtered three or four times through bibulous paper, and the preparation is complete. Nothing more remains but to pour it into tin cans or oak barrels, and it is ready for market. The oil is of a straw yellow, with scarcely any smell or taste, and is known as natural medicinal oil.

In the mean time other fishermen, having carefully sorted, washed, and dried the livers, place them in a pot 


\section{I4 The Commercial Products of the Sea.}

of tinned sheet iron. This tinned pot is then put into a larger iron pot, half full of water, which on becoming heated causes the livers immediately to begin to give out their oil. Some makers introduce steam from a boiler between the two pots, and others let the steam out directly on the livers. The first yield by these methods of regulated heat is removed by spoons, filtered when cold, and reserved for medicinal use under the names of "steamboiled medicinal" and "ordinary bright." The after yield is used in medicine, though somewhat redder; it is called "bright brown." Finally, those portions of liver that will not dissolve by themselves or by a mild heat are roughly boiled down to yield "dark brown," or tanner's oil, the black residuum being used with other fish refuse for manure.

There is a great difference between one year and another in the quantity of oil the cod's liver yields. One year it may require 600 livers to make a barrel of oil ; in others, 200 are sufficient.

In I840 42,737 barrels of cod and shark oil were sent away from Norway. In 1848 1,296,572 gallons of cod oil were shipped, against only 65,600 in 1846 .

From the coast of Norway the average export of fish oil from I85I to 1855 was 52,900 tuns, and from 1856 to I $860,59,6 \mathrm{I} 7$ tuns per annum; from I 86 I to $\mathrm{I} 866,7,750,000$ litres per annum. In 1877 130,600 barrels of cod-liver oil were shipped, valued at $£ 386,600$. The catch of each boat yields from 8 to 20 barrels of liver. Fresh livers, for medicinal oil, fetch from $27 s$. to $3 \mathrm{I} s$. per barrel; old livers, from 22s. to $26 \mathrm{~s}$. At the early part of the season the fish are rich in liver, so that from 250 to 300 of the net-caught fish yield a barrel of liver, while 50 to 100 more fish taken on lines would be required. As the season 


\section{Fish Oils and the Fisheries connected therewith. 2 I 5}

advances the fish become perceptibly poorer, and it will take 400 to 450 to fill a barrel, while on the sea-board or western side of the Lofoden Islands from 600 to 700 livers are requisite.

In Sweden the residue from fish which have been salted are placed in large boilers, with waste herrings and others, a small quantity of water, and boiled or frequently steamed till the mass is dissolved; cold water is then introduced, and the oil floats at the top. This is skimmed off, clarified, and put into casks. It is of a brown colour, good for burning and other uses, but is said to be too fluid for the leather workers.

The export of fish oils from Iceland (principally from the shark) amounted in 1867 to $4,186,560 \mathrm{lbs}$. An ordinary year's export, however, may be put down at about $2,700,000 \mathrm{lbs}$.

One of the most important secondary products of the fisheries in Russia is the oil obtained, of which the quantity annually extracted represents a value exceeding $£ 7$ I,500. This is either employed for medicinal use, for food, or for technical purposes. The medicinal oil is obtained from the liver of the cod, which is cut up when it is quite fresh, and subjected to the action of steam heat. The oil used for food is obtained from the fat surrounding the intestines of the sturgeon and the sandre (Leucoperca sandre). It is washed, and in its fresh state melted in steam boilers. The oil or fat is chiefly used to add to the barrels of caviare, when the fish spawn is itself not sufficiently fat. At the seat of production fish oil is also largely used instead of vegetable oils.

The common fish oil employed for technical uses in soap factories, tanneries, for lighting workshops, etc., is generally obtained by putrefaction, which decomposes the 
membranes by which the fish fat is surrounded, and facilitates its flow. The quantity of this oil made amounts to more than 100,000 pouds of $36 \mathrm{lbs}$. The oil used to be extracted not only from different parts of fish, but large quantities of small fish were also rendered down for their oil, especially the herrings of Astrakhan and many small species of Cyprinoides. The Government have of late years, however, put a stop to this practice of using small fry for the purpose, although the extraction of herring oil is permitted, because such enormous shoals of these can be obtained that it is impossible to salt them rapidly enough when they are fresh, hence the policy of turning them into oil.

Not only are the livers of the codfish now used to extract oil from, but those of a number of other fish are sought for the purpose. Thus, the livers of the ray, the shark, and other Squalus are used in Iceland and Norway to extract an oil used for lighting and employed by curriers. In British Guiana an oil is obtained from the liver of the saw-fish (Pristis pectinatus), which is used for lighting, and by the immigrants from India for anointing their bodies. A liver will yield from 15 to 20 gallons of oil. In Cambodia a fish called tussoc yields an oil remarkable for the proportion of stearine it contains.

The quantity of fish oil obtained in India has much declined of late years. From Bombay, Sind, and Madras, in I865, more than 3,750,000 lbs. were shipped. In Madras a good deal is still made. The Indian fish oils are mainly of two descriptions-medicinal and common.

The natives prepare fish oils from the livers of sharks, skates, saw-fishes, rays, cat-fishes, oil sardines, and other kinds. The cat-fish livers have the most oil about January, just before they are breeding. When the livers of 


\section{Fish Oils and the Fisheries connected therewith. 2 I 7}

these fish alone are employed, they are heated up to $130^{\circ}$ in water, having about one and a half inches in depth over them. After 15 or 20 minutes, on being stirred, the froth rises, and the oil is skimmed off into large vessels, in which state it is sold as fish oil. There is no washing of the livers-fresh or semi-putrid, bloody or clean, they all are put in the pot, and the oil undergaes no straining.

A large quantity of oil is also procured in India from sardines, and especially from the "louar" (Clupea Neohowii), which is obtained from August to November, and then treated with boiling water to separate the oil which floats. Oil is also obtained from the livers of several Siluroids, but it is only during January and February that the organs are rich enough in fatty matter to be remunerative. The oil sardine seems to form the basis of all the oil obtained in India, for if not prepared from it, a great amount is from the sharks and other fish who live upon them. But the oil sardine is very capricious as to its arrival and departure. In I 864 the enormous quantity of I 48,206 cwts. of fish oil was shipped from the port of Cochin. In I 865 still larger exports were made. During the next five years scarcely anything was done in the trade; but in $187 \mathrm{I}$ the shoals of fish reappeared as abundantly as ever, and with these shoals the sharks returned. When the sardine fish first arrive they are lean, but by October, and sometimes before, they become fat, and are well adapted for extracting oil from. They are captured either by long floatnets, attached at either end to a boat, and by making a circuit the shoal is surrounded; or else several canoes put off together, and pull to a shoal of these fish, which they take by cast-nets. A boat-load of sardines is computed to hold I 4,000 . 
2 I 8 The Commercial Products of the Sea.

If Clupea lemuru, Bleeker, is the oil sardine, this fish would appear to be found in the Malay Archipelago.

At Rangoon the average quantity of fish oil obtainable is over 77 tons per month; but from November to May much larger quantities are procurable, it being only made at those times. It is used for lamps, and even for curries and frying fish; and is obtained by boiling the intestines of some fish, the heads of others, and even whole fish, in an iron vessel with water in it, and the fatty substance as it floats is skimmed off into another pan, and boiled till the oil floats. It is said to be chiefly extracted from the Anabas scandens, Barbus chola, Chipea palasah, and the intestines of the Ophiocephalus striatus.

Tunny oil is extracted at Tunis from the head, backbones, and refuse of the fish, which are placed in a large cauldron capable of holding 800 heads and 400 skeletons, and allowed to boil for 24 hours. The value of the tunny oil exported from Tunis in I87 I was $£ \mathrm{I} 600$.

Herring Oil.-For I 5 years or more, herrings have been chiefly converted into oil in Russia, as there exists a prejudice against eating them, under the belief that they are rabid, from the habit they have of turning round and round when they are spawning. About $100,000,000$ of these fish are sacrificed annually for oil making. During the three or four weeks that the influx of fish continues, 100,000 to 250,000 pouds (of $36 \mathrm{lbs}$.) of herring oil are made on the Volga, according as the fishery is abundant and the fish more or less fat. The manufacture is carried on in this manner. The herrings are placed in open casks, containing about I000, and boiling water poured over the mass. Several days elapse before the fish enter into putrid fermentation, under the action of the air, the heat, and the hot water, and the oil separates. The whole is trans- 
formed into a half-liquid, reddish paste, of a disgusting odour. But when once this putrid fermentation has commenced a day suffices. The oil is then collected from the surface, and the mass thrown away.

In Japan oil is extracted from the herrings which are caught on the coast of Yesso and the north of Nipon. The fisheries afford employment to thousands of the inhabitants, and are a source of immense profit to the Japanese, who farm them from the various daimios who are charged by the Japanese Government to protect this island. The prices vary from $48 s$. to $56 s$. the picul (I $30 \mathrm{lbs}$.) In Kanagawa this fish oil is only about half that price. The principal market for fish oil is Hakodate.

The oolachan or houlican (Thaleichthys pacificus) - a fish somewhat larger than the sprat, very delicate, and of exquisite flavour-is found in abundance in the waters of British Columbia. It has been suggested that these fish might be cured in their own oil, or marinated after the manner of pilchards. They are so full of oil that it is said those caught in the north will burn like a candle, They enter the river in millions in the month of April. and their presence is at once made known by the seagulls, which wheel about the shoals, and dart among them for their prey, startling the usually still Fraser with their shrill cries. Their run lasts about three weeks, during which time they may be caught in countless myriads.

Eaten fresh, they are most delicious, and are also excellent packed in salt or in a smoked form. The fish are caught with a pole about Io feet in length, along which are arranged for five feet at the end nails like the teeth of a comb, only about an inch and a half apart. The comb is thrust smartly into the water, brought up with a backward sweep of the hand, and is rarely found without three 


\section{The Commercial Products of the Sea.}

or four fish impaled on the nails. Frequently a canoe is filled with them in less than two hours by a couple of hands.

By warming over a slow fire, or by heating in water, an oil is abundantly obtained, which is used for the same purposes as cod-liver oil, and with as much, if not greater, benefit. The oil when cold is of the consistence of thick cream, white in colour, with but little odour, and by no means unpleasant to the taste-in fact, those who use it very quickly acquire a partiality for it. The Indians make large quantities every season, and with them it supplies the place of butter. They cannot live without it, and it forms a great article of trade. When properly filtered, a fine pellucid oil, of a delicate, pale yellow colour, is obtained. Some of the northern natives allow the fish to become half putrid, and then express the oil by pressure upon boards.

There is no doubt but that this oil might become of great economic value. It has been given medicinally, and will probably be found useful where cod-liver oil or other hydro-carbonaceous food is indicated.

Menhaden Oil.-A fishery eagerly prosecuted for the oil obtained from the fish is the menhaden, on the Atlantic coast of the American States. Of the natural history of the fish not much is accurately known, but it is stated to be the Brevoordia menhaden (the Alosa menhaden, Mitchell), and belongs to the herring family, differing from it in having a deep notch in the centre of the upper jaw. The fish is from 8 to 14 inches in length. It frequents the Atlantic seacoast, from Maine southward, but has not been noticed south of Cape Hatteras. It is sometimes sold in the markets as a table fish, but is usually considered too oily for food. Among the fishermen, however, it is esteemed a fine-flavoured fish. This is the source of the 


\section{Fish Oils and the Fisheries connected therewith. 22 I}

American fish oil. Whale oil formerly sometimes bore the name, but has long ceased to do so; and oils obtained from other fish have their own specific designation.

The manufacture of oil from porgies or menhaden is an important industry in some of the American Atlantic States. The value of this fishery to the State of Maine is estimated at $£ 300,000$. Forty steamers, 350 sailing vessels, and 500 boats, with an aggregate of 3500 men, are employed in this fishery, of which the coast of Maine is the largest and most profitable field, yielding more oil to the number of fish caught. Hence this interest is becoming a local one, and the number of factories is constantly increasing.

At Portland nearly all the factories are located in Lincoln County. About 500 hands are employed, and the return of produce is to the value of $£ \mathrm{I} 00,000$. In the prosecution of the business there, a numerous fleet of small vessels and steamers are engaged, giving employment on the water and land to probably not less than 1000 men.

The menhaden fish emerge from the warm waters of the Gulf Stream, and strike the coast of New Jersey in the month of April, reach the coast of Maine by May or June, and remain till October, when they return south.

The fishery is carried on by the very smartest of yachts, not fancifully rigged or equipped, but the fastest sailers that can be built or bought. Some of the best boats in the yacht clubs find their way into this service. In size these vessels rarely exceed 20 or 30 tons; say, 18 feet beam and 50 feet over all. Built to stand the heavy gales on the coast, and well provided with light and heavy sails, they are able to cruise in weather that sends fancy boats into the harbours. The fishing yachts are manned with from eight to ten men each. To make the outfit complete, two sloops, called carry-ways, are attached to each yacht. These are 


\section{The Commercial Products of the Sea.}

smaller than the latter. Each of these will hold 70,000 menhaden (I6 or I7 tons). They are employed in taking the fish ashore after they are caught. The seines are made of strong cotton twine, and are I 30 fathoms ( 780 feet) long, and from 80 to 100 feet deep. At the eastern end of Long Island, where the fishing is in deep water, the depth is even greater. Along the bottom of the seines run lines, arranged so that they can be drawn up like an oldfashioned purse-whence the name "purse-seines." The top of the seine is attached to buoys of cork or wood, and these, when the whole is thrown into the water, hold the upper edge at the surface, while the remainder hangs vertically beneath it. The seine is loaded into two boats, which also form a part of the outfit of the yacht, and are always with her when not engaged in taking fish.

Thus furnished, the yachts start on a cruise in search of the fish, which go in immense schools. When a school is met with, it is necessary to drop the seine in front of them; otherwise no fish would be taken, as they would swim away in front before the seine could be closed around them. The boats get ahead of the school, and pay out the seine as they separate. When the school is fairly in the seine, the boats come together and completely surround the fish. At the point where the boats first started, a heavy weight, called a "tom," is attached to the bottom of the seine, and to this weight, which rests upon the bottom, are fastened the lines which "purse" up the bottom, and prevent the fish from escaping below. When the bottom is drawn together, the men haul the seine into the boats and shake the fish down into the "bunt," as the bag or purse formed by the seine is called. They then signal for the carry-ways, which come alongside. The fish are taken out of the seine into the carry-ways by means of dip-nets. If the school is 


\section{Fish Oils and the Fisheries connected therewith. 223}

a large one, and most of the fish have been taken, the carry-ways are despatched at once to the factory on shore. If not quite loaded, they are generally retained until another school is taken, when they are sent off.

When they reach the factory, they run alongside of the dock, and the fish are hoisted out into a car. When this is full, it is hauled by steam up the track leading from the dock to the cooking-vats and thrown into them. When a vat is full of fish, water from elevated tanks is let on until the fish are covered. Then steam is introduced and the whole is boiled. To properly cook a tankful of fish takes from 20 to 40 minutes, according to circumstances. In some factories the cooking is very short; in others, it is preferred to take a longer time, so that the fish shall be equally cooked throughout the mass. At the conclusion of this process part of the oil has been boiled out, but by far the greater portion still remains in the fish; and this must be removed by means of the hydraulic press. With one of these machines from 200,000 to 300,000 fish can be pressed in Io hours. Two curbs are used with these presses, so that there is no delay in the work.

As soon as the oil has ceased to run from the curb, the press is lowered, and the curb, containing the mass of scrap, is rolled away over small turn-tables and out on the track to the scrap-houses, where the two handles holding up the bottom are released, and the whole mass is thrown out. While this is going on another curb has been put in the press. The curb then comes back to the vats for a new load. In this way the work goes on until all the vats are emptied. The oil and water as it comes from the press runs down to the separating-tank. In this tank there is a partition from top to bottom. The oil flows across this in two openings, cut in the top, while the water passes under 


\section{The Commercial Products of the Sea.}

the bottom. Here men stand and skim off the oil, while the water is allowed to run away. In some establishments the separating-tank is so arranged that the oil can flow into the oil-tanks without having to be dipped out. This of course, saves much labour.

The oil is now stored in the tanks. When a better grade of oil is desired, it is bleached by exposing it in a shallow "sun-tank" to the action of the sun. If a still finer quality is required, another kind of tank is used, having a frame for the reception of a sash, so that all dust and dirt is excluded, and the oil is bleached without waste. In the bottom of the vats, in the separating-tanks, and elsewhere, a great mass of sediment collects, consisting of a fine refuse, mixed with some oil. This is put into the "gurry-tank," steam is, turned on, and it is thoroughly cooked till the oil rises to the surface; the "gurry" that remains is then put up in barrels and sold to the soapmakers, who use it for making " fish-oil soap."

These fish yield a large quantity of oil, the highest percentage being about four and a half gallons per barrel of fish in the month of September. A thousand fish will yield on the average I 3 to I4 gallons of oil, though this depends largely upon the season, and the good or bad condition of the fish.

The uses to which the oil is put are very numerous. It is said to be good for table purposes, and, when properly prepared, the best kind is extensively used under the name of olive oil. As a vehicle for paint, it has a good body, and does not readily abandon the paint which may be mixed with it. It is quite rare to find such paint rubbing off in the shape of powder. Much of the linseed oil in the market has a large amount of menhaden oil mixed with it. This is no disadvantage to the painter's work, but a serious 
Fish Oils and the Fisheries connected therewith. 225

detriment to his pocket. Fish oil cannot, however, be used for lubrication. Its body and the rapidity with which it absorbs oxygen and "gums" entirely precludes its application to machinery. The literal and metaphorical bad odour formerly attached to fish oil is passing away. It has been found that by cooking the fish while they are fresh a perfectly sweet oil can be obtained. The vile smell of former (and to some extent of latter) days resulted from the treatment of stale or decaying fish. The common kind of oil is extensively used by curriers and in other trades, and the flesh and bones, after the oil is extracted, form a manure which is in great demand for the cotton fields of the south.

The amount of capital invested in this business is very large. In 1873 it was ascertained that $£ 500,000$ was invested in 43 factories scattered along the coasts of Long Island Sound, Rhode Island, Massachusetts, and Maine. The quantity of fish caught was' I,I 73,700 barrels. The yield of oil, 2,250,000 gallons, was valued at over $£ 200,000$; and that of fish manure, 36,000 tons, at $£$ I 25,000 . 


\section{CHAPTER VII.}

THE SHARK FISHERY FOR THE OIL OBTAINED.

Fishery in Norway-The Greenland shark-Mode of capture-The basking shark-Sharks in Australia and New Zealand-Shark fishery in IndiaSharks' fins exported to China for food.

The Shark Fishery of Norway.-There are four species of the shark tribe which inhabit the northern latitudes, viz., the Scymnus borealis or Squalus glacialis, Selache maximus, Squalus acanthias, and Squalus spinax niger.

The Greenland shark (Scymmus borealis) frequents in numbers the banks which are traced in a line nearly the whole length of the western coast, at distances varying from 50 to 100 miles from the main; in greater abundance, however, on that portion which lines the coast of Nordland and Finmark, as far as the North Cape, and between the latter and Cherry or Bear Island. They are to be met with, however, all over the North Sea and Arctic Ocean, as well as in most of the large fiords on the west coast, at depths varying from 100 to 200 fathoms.

Formerly the fishery was exclusively confined to the immediate vicinity of the coast; but of late it has been more specially and lucratively prosecuted on the banks, commencing in about lat. $68^{\circ}$ to the North Cape, and between that and Cherry Island. The vessels employed in 


\section{The Shark Fishery for the Oil obtained.}

this fishery generally range from 25 to 35 tons, manned with a crew of six men. They lie at anchor on the banks with $\mathrm{I} 50$ to 200 fathoms water, moored by a grapnel weighing two cwt., with a warp about 300 fathoms in circumference.

A box perforated with holes, or a canvas bag containing the residuum or refuse of blubber, after the oil has been extracted by boiling, is attached to the line not far from the bottom, near the grapnel. Globules of oil are found to ooze out or to percolate through the holes or bag, and to float away in a continuous stream, serving as a decoy, in a similar manner as the cod ova are applied in France, where they are thrown into the sea as ground bait to attract the sardines. Led by this stream, the sharks are guided to the main bait, which is attached to a thin iron chain; of from one to two fathoms in length. This is fastened to a line of about the thickness of the stem of a common tobaccopipe. At the end of the chain the hook is attached, which is usually of the size of ' a salmon-gaff, and is baited with some kind of fish, or, what is preferable, about a pound of seal blubber. The seals from which this blubber is taken are generally caught at Spitzbergen, and there salted fresh. No kind of bait appears so efficacious or so attractive as this, and it throws off readily its fatty particles, which being carried to a considerable distance, form a trail to the bait, which the fish greedily take, if of blubber; but, it has been observed, not so readily if the blubber is at all rancid. Five barrels of blubber is considered necessary for the season, and appears to be the average quantity used by each vessel.

On hooking the shark, he is hauled to the surface of the water by the aid of a single purchase. Each vessel is furnished with four of these, two on each side. The line, 
being small, is only calculated to bring the fish to the level of the water; his nose is then hauled a little above the surface, and a smart blow is immediately struck, by which he becomes stunned. A large hook at the end of a pole, attached to a strong tackle, is then driven into the fish, and by this means he is hauled on deck. The belly is cut open and the liver taken out. A hole is then made in the stomach for the purpose of inflating it with wind, which done, the hole is again tied up, the fish got into the water, and permitted to float away. The stomach being inflated prevents the fish sinking, and it soon drifts out of sight. By being kept afloat, the fishermen imagine that the carcase cannot injure the fishing grounds.

The length of this fish varies from io to 18 feet. The value depends upon the size, quantity, and quality of the liver, which yields from one-half to two barrels, or from 15 to 60 gallons of fine oil each.

This shark is caught nearer the coast, as far as Waranger Fiord. The fishery commences about the end of September, and is continued through the winter until the end of February with deep-sea lines, in open boats manned by five men.

The bait preferred is either porpoise or seal blubber. The line is retained on the finger, and as soon as the man feels that the bait has been touched, he gives a sharp jerk, in order to fix the hook more firmly in the jaws of the fish. Some skill and experience is required to effect this at the proper moment, as the fish no sooner finds himself caught than he spins round the line, and on these occasions the line is liable to be severed by the sharp edges of the skin. The greatest activity is, at the same time, requisite in hauling the fish to the surface, in order to check the rotatory movement. 
It happens not unfrequently on these occasions that several sharks come to the surface of the water in the wake of the one hooked, swim round the boat, and are caught by means of a swivel hook, fixed to a long gaff, which each boat is furnished with. They are then secured by a hook and strong line to the stem of the boat, until they can be hauled alongside.

The result of a fishery carried on in open boats depends greatly on the wind and weather. When a boat's crew obtain from two to four barrels of liver, they are satisfied. Under favourable circumstances, however, they obtain from seven to eight; and if during the course of the winter they can get from 40 to 50 barrels, the catch is esteemed a remarkably good one. Besides the liver, when the fish can be towed to the shore, the flesh is converted into food for the cattle, if there is a scarcity of dried cod's heads, which are prepared for that purpose.

The flesh is occasionally used also for human food, being cut up into long strips and wind-dried in the open air, or buried in the ground until partially decomposed, when it is taken up and prepared in a peculiar manner, so as to become edible. It requires, however, an Arctic stomach to digest it.

The basking shark (Selache maximus), another of the genus, the largest of sea-fish, is found all along the coast from Ryvarden, lat. $59^{\circ} 3 \mathrm{I}^{\prime}$, up to Finmark. This fishery was for a long time pursued with great activity and perseverance, and with such success as for a series of consecutive years to form the staple and chief support of the inhabitants of the districts in which it was carried on. Of late years their numbers have decreased so as to diminish the importance it had for years maintained. The increased herring fishery which has followed, however, fully compensates for the decline. 
This shark differs from his fellows in not being a voracious fish ; consequently it is neither to be enticed nor caught by the same kind of bait or mode of fishing as pursued with the Scymmus borealis, but rather that followed with the whale. About the last of the dog-days, when the water and weather are at their highest temperature, this shark makes his appearance on the coast, and the fishery immediately commences.

Large open boats are generally employed, from 37 to 42 feet in length, each boat being manned by four men and furnished with harpoons similar to those used in harpooning the sturgeon. The harpoon is attached to a line proportioned to the depth of water on the ground selected, which usually is from 300 to 400 fathoms. This rope lies coiled up in the bow of the boat.

Thus equipped, the fishermen, selecting a light breeze and warm weather, cruise about under a triangular sail, near the mouth of the fiord the fish are in the habit of seeking. They are generally found lying perfectly still near the surface, apparently basking in the sun, and slowly follow in the wake of the boat as soon as discovered; the large fin on the back, standing prominently above the surface of the water, indicating their presence and movements.

The fishermen imagine, from his following the boat, that he is decoyed to the surface by the small triangular sail, which he mistakes for another fish. Certain it is that, whatever the temptation may be, the fish follows closely the boat without being disturbed for a considerable time, although sometimes carrying a stiff breeze. When the fish approaches close enough, the harpooner, watching his opportunity, sends his harpoon as deep into the body of the fish as he is able. Then arrives the perilous moment, for 
the fish no sooner feels the weapon than he dives with great celerity.

Everything must be clear, to allow the line to run out freely; and it does so with such rapidity as to require one of the men to be incessantly pouring water over the swivel on which the line traverses, to prevent its igniting. Should the line unfortunately catch any projecting piece of wood, or meet with any impediment, the boat is inevitably capsized ; or should one of the men, through carelessness or accident, be caught by the line round the leg or arm, which has occasionally happened, he gets hauled down by the fish. Another man, therefore, always stands ready with an axe to cut the line; but when such an accident does occur, generally both man and fish are lost. When the fish has reached the bottom, he proceeds along it, continuing to drag the boat with him, until his strength becomes exhausted. A lean fish holds out longer than a fat one, and will sometimes continue dragging for four and twenty hours, while a fat one generally gets tired out in three or four hours.

When thoroughly exhausted, the fish is hauled up to the surface alongside the boat, and with a long, sharp knife, the fin is instantly cut off to prevent his striking, as a blow would readily smash the boat. $\mathrm{He}$ is then speared until quite dead. Before commencing to extract the liver, the fish is fastened by sundry ropes to the mast, and turned, when one of the men, provided with a long knife for the purpose, opens the fore part of the belly, which enables him to take out a large piece of the liver. $\mathrm{He}$ then insinuates his arm in, and separates all the fibres and integuments, so as effectually to release the liver, which operation requires to be carefully performed. When com. pleted, the stomach is ripped up from end to end. The 


\section{The Commercial Products of the Sea.}

liver then floats out, the belly fills with water, and the fish is cast adrift and immediately sinks. The liver is then taken into the boat, and the fishery is concluded.

The size and fatness of the fish vary considerably. The prevailing size there is from 30 to 35 feet. They have been caught as long as 40 feet, but this is now a rarity. Young fish are never met with ; they doubtless keep in deep water until of mature growth. The size of the liver depends greatly on the condition of the fish. They usually render from four to seven barrels of liver, occasionally as much as from Io to I6. Instances even have been known where as much as 24 barrels have been obtained from a single fish; but this is of very rare occurrence. When the liver is rich, six barrels will produce five barrels of oil of 30 gallons each. No other part of the fish is utilized.

Of the remaining species of the shark tribe, there are only two, besides the foregoing, which are of any importance on this coast. The first is the picked dog-fish, Squalus acanthias, which in former times was in great abundance along the whole coast from Gothenburg, and afforded lucrative employment to the fishermen. At present the fishery is carried on during the whole of the summer from the Naze to the North Cape, in the fiords as well as along the coast.

This is a ravenous fish, which is caught in various ways. About midsummer he is observed to swim near the surface, and can then be taken in nets, as well as with lines, precaution being taken to protect the line by proper "serving" for a short distance beyond the hook, to prevent its being bitten off. This fish is eaten sometimes fresh, but must be skinned before being cooked. When cooked in this way, it is considered rather a delicacy. It is also dried as split stock-fish for consumption in the country, 


\section{The Shark Fishery for the Oil obtained. 233}

as well as for export to Sweden, where it is greatly appreciated. The yolk of this shark's egg is used by the inhabitants as a substitute for other eggs in their domestic economy. The skin is employed by joiners and turners for polishing purposes. The liver is exceedingly rich, and makes a very fine oil.

The other species is called in Norway the kulp or hoastorsk (Squalus spinax niger), and is the smallest of the shark tribe. It is met with in all the deep fiords along the coast, where it commits great mischief by nibbling off the baits from the deep-sea lines which are set out for the ling and the torsk (Brosmus vulgaris).

Lines with single hooks are never laid out to catch this fish; but at the end of the summer and autumn, and in some fiords all the year round, instead of a single hook, they employ Io to 12 , placed one above the other, baited with half-decayed or tainted fish. The depth of water selected is from 60 to 100 fathoms. As the kulp is a sluggish fish, bites lightly, and is small, some experience is required to know when he bites and is secured on the hook, especially if there is any wind. The line, however, is not brought up each time the bite is felt, as there are many hooks; a simple tug is given at every supposed bite. The fish being once hooked generally remains quiet, and one usually finds 8 or Io fish caught when the line is drawn up. As this fish comes in shoals and takes the bait freely, an experienced, skilful fisherman will occasionally, during a single night, obtain a rich booty. The kulp will not bite during the day. It is not eaten, but sought after exclusively for the liver, which is unusually rich, and yields a very superior kind of oil.

In the bays about the peninsula of Kola, Lapland, the shark fishery is now vigorously carried on by the Russians; 


\section{The Commercial Products of the Sea.}

the species chiefly taken is the Scymmus borealis. The fishery is only prosecuted off the coast in small undecked boats, manned by four men. In autumn the sharks are in the best condition and yield the most oil ; in summer they scarcely afford any. Some of the large species of basking sharks will yield as much as $1600 \mathrm{lbs}$. of oil. The crude shark oil sells in Russia at about $6 s$. the poud of $36 \mathrm{lbs}$., and when refined is worth double that price.

Sharks are caught on the New Zealand shores in great numbers, during the months of November, December, and January, by the natives, who use them as an article of food. The fins can be procured at a very moderate rate, and fetch a good price in the China market.

The Government of the colony of Victoria having published a scale of rewards for the capture of sharks, the pursuit has become a frequent occupation among the fishermen and boatmen of Hobson's Bay. In one week in May, I 877 , over 3500 sharks were captured by the fishermen of Sandridge, some of whom earned from $£_{3}$ to $£ 4$ per day. One immense shark, measuring between 15 and I6 feet in length, was caught in the bay.

It was stated some years ago that there were 13 boats, manned with 12 men each, constantly engaged in the shark fishery at Kurrachee. One boat will sometimes capture at a draught as many as Ioo sharks of different sizes. The average capture of each boat probably amounts to about 3000 , making the number of sharks taken not less than 40,000 a year. The great basking shark, or mhor (Selache maximus), is always harpooned; it is found floating or asleep near the surface of the water. The liver of a large fish of this species yields there eight barrels of oil. The oil is of a very low specific gravity.

The fish, once struck, is allowed to run till tired; it is 
then pulled in, and beaten with clubs till stunned. A large hook is now hooked into its eyes or nostrils, or wherever it can be got most easily attached, and by this the shark is towed to shore; several boats are requisite for towing. The mhor is often 40, sometimes 60 , feet in length; the mouth is occasionally four feet wide. All other varieties of shark are caught in nets, somewhat like the way in which herrings are caught at home. The net is made of strong English whipcord; the meshes about six inches; they are generally six feet wide, and from 600 to 800 fathoms, or from three-quarters to nearly a mile in length. On the one side are floats of wood about four feet in length, at intervals of six feet; on the other, pieces of stone. The nets are sunk in deep water, from 80 to 150 feet, well out at sea.

They are put in one day and taken out the next, so that they are down two or three times a week, according to the state of the weather and success of the fishing. The small sharks are commonly found dead, the larger ones much exhausted. On being taken home, the back fins, the only ones used, are cut off and dried on the sands in the sun; the flesh is cut off in long strips, and salted for food; the liver is taken out and boiled down for oil ; the head, bones, and intestines left on the shore to rot, or thrown into the sea, where numberless little sharks are generally on the watch to eat up the remains of their kindred. The species chiefly caught are the Rhyncobatus pectinata, $R$. levis, and Galiocerda tigrina.

Owing to the large size of the sharks from which the livers are taken, the Malabar fishermen, unlike those of Sind, are unable to capture them with nets. Putrid beef or porpoise flesh is employed, large pieces being buried for a day or two previous to being used. The hook is attached by a chain to the line whilst the fishing is carried on. 


\section{The Commercial Products of the Sea.}

In Sind large quantities of oil are prepared from the livers of different fish. The sharks (Carcharias melanopterus) are caught principally in October and November, for at that period the livers are much more developed than at any other season. The oil obtained from them is of the same quality whatever the season, but they furnish about three times the quantity in autumn that they do in any other season. The most esteemed livers are firm, and of a rose colour; those which are whitish and flabby are rejected as inferior. After having separated the vesicle, the livers are washed, and all the blood is taken out through incisions. They are then cut into medium-sized pieces, which are placed in a large earthen vessel with enough water to cover them. They are now heated for I 5 or 20 minutes, after which they are allowed to cool. The oil, which soon floats to the surface, is gathered in ladles made from the half of a cocoa-nut, and is then poured into glazed earthenware jars. It is now passed through a sieve, and all which does not pass through is thrown away. Three or four days later, it is again filtered through a thick strainer, in order to separate the abundant deposit of stearine, and it is necessary to repeat this operation four times, at intervals of from 20 to 25 days, to separate the deposit; after which the oil remains clear, of a fine straw colour, and smelling very much like cod-liver oil. Thus prepared, it is reserved for medical purposes.

In India a manufacture of inferior oil is also carried on, which is used for lighting and other domestic purposes. It is prepared from the liver of sharks, rays, and other sorts of fish mixed. The livers are heated without being previously washed or picked, and the product is not purified.

From Bombay sharks' fins weighing 6000 to $9000 \mathrm{cwts}$. are exported annually, valued at from $£ 14,000$ to $£ 20,000$. 


\section{The Shark Fishery for the Oil obtained.}

Besides the local catch, large quantities are imported from the Arabian and Persian Gulfs. There is a small export of these fins from Madras to the extent of 250 to 300 cwts. annually. They are assorted into the "white" and "black," the former being the dorsal fins, which are uniformly light coloured on both sides, and reputed to yield more gelatine than the other; the "black" are the pectoral, ventral, and anal fins, which are less esteemed than the white, and consequently realize a lower price.

Sharks' fins are sent to China from various quarters; from Akyab, Sumatra, Manila, Borneo, the Sandwich Islands, and other places. They are much esteemed as a food substance, being used for making soup. 
238 The Commercial Products of the Sca.

\section{CHAPTER VIII.}

THE ISINGLASS OF COMMERCE.

Description and uses of isinglass-Fish from which obtained-Russian isinglass -Vesiga-Brazilian isinglass-West Indian isinglass-North American isinglass-Chinese isinglass-Fish maws and sharks' fins.

ISINGLASS, one of the purest and finest of the animal glues, is a product the preparation of which was long carried on almost exclusively in Russia, and chiefly obtained from the sturgeon. The value of the isinglass from this fish is chiefly due to its peculiar organic texture, on which the property of clarifying wines and beers depends. No artificial isinglass, however pure the gelatine, or identical as to chemical composition with the air-bladder of the sturgeon, answers the purpose of the preparers of fermented liquors.

Isinglass is brought to market in different forms ; sometimes in that of plates or lumps, or in the form of a bag or purse, at other times rolled up in different shapes, which pass under the names of book, leaf, long and short staples, tongue or pipe, and it is cut into fine threads. When of good quality, isinglass is of a whitish colour, thin, and semitransparent, but tough and flexible, destitute of taste as well as of smell. The inferior kinds are thicker, yellowish coloured, opaque, and sometimes have a fishy smell and taste. When placed in cold water, it becomes soft, then 
swells, and if held up to the light in this state is opalescent. In boiling water pure isinglass is entirely dissolved, with the exception of a very minute proportion of impurities. Though the best isinglass is thus completely dissolved in hot water, yet most of that met with in commerce does not become so, in consequence of the presence of albuminous parts.

The fine shreds into which it is cut and kept in shops give great facility for making a jelly in the shortest possible time. This can be made palatable and nourishing by the addition of sugar and milk, acids or spices ; about one-third or half an ounce is sufficient for a pint of water. It may also be taken in the form of a soup, with the addition of salt, spices, and sweet herbs, or it may be employed medicinally as a demulcent, either externally or internally. The best kinds of isinglass are alone employed in articles of diet and for the best confectionery, being added in small quantities to other, especially vegetable, jellies, to give them a tremulous appearance; but gelatine is now frequently substituted.

Isinglass appears to have been discovered many ages since, for certainly it was known to the Romans, being mentioned by Pliny. It is obtained in several parts of the world from the air-vessels (termed "sounds" or "maws") of various species of sea, estuary, and fresh-water fishes, England procures the best from Russia, where it is principally collected from the family Accipenseridee or sturgeons, and the following species, according to Brandt and Ratzeburg, furnish it:-Accipenser sturio, the common sturgeon; $A$. huso, the great sturgeon ; $A$. Guldenstadtii, the osseter; $A$. rathenus, the sterlet; $A$. stellatus, the sevruga or starred sturgeon, in which account are likewise included the $A$. brevirostris; $A$. schypa; $A$. Ratzeburgii; 


\section{The Commercial Products of the Sea.}

A. Lichtensteinii; also A. maculosus, and A. oxyrhynchus from North America.

Isinglass has, in a measure, had its consumption checked by its high price, and substitutes are employed, such as gelatine (of which it is itself the purest form). It is of a highly nutritious and unirritating nature, admirably adapted for the sick room, and the preparation of some forms of confectionery and cookery, besides being employed both externally and internally in medicine, in the preparation of court plaster, in some arts and manufactures, but more extensively for clarifying or fining wines and beer. The brewer employs it as follows:-Some, having been finely divided, is dissolved in sour beer, to the consistence of a

FIG. I8.

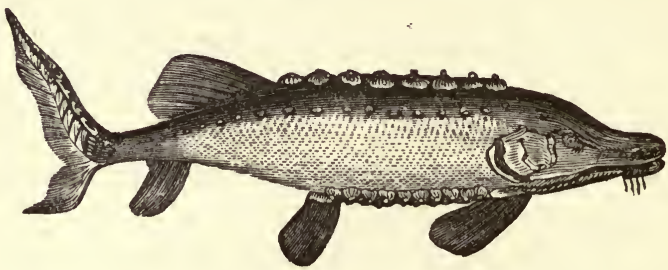

The Sturgeon.

thick mucilage, and a portion is added to the fluid which it is intended to clarify, and after a longer or shorter period, suspended substances subside. Some suppose that all floating particles become entangled in the isinglass, and, uniting with it, form an insoluble compound which becomes precipitated; others, that when dissolved in a fluid it lessens its affinity for the suspended particles, which, being thus set free, subside.

The finest description of isinglass is thin, tough but flexible, white, semi-transparent, and destitute of both taste or smell; it almost entirely dissolves in boiling water, and 
provided it contains as much as one-hundredth of its weight of gelatine, has the property of gelatinizing or assuming the form of a soft, tremulous solid as it cools. The inferior sorts are thick, opaque, white, or yellow, having a fishy taste and smell, and only partially dissolve. The commonest kind, termed cake isinglass, is of a brownish colour, having an unpleasant smell, and is only used in the arts, and for the preparation of glue. The Brazilian isinglass is very inferior to the Russian, and is in the form of pipe, block, honeycomb, cake, and tongue isinglass. The North American is like long ribbons, produced from the air-vessels of the Otolithus regalis, B1. Schn.

Russian Isinglass.-Isinglass is obtained in Russia from the interior lining of the swimming-bladder of the sturgeon (Accipenser), the Silurus glanis, the Lucioperca Wolgensis, Pall., and the large carps. The Coregonus leucichtys also furnishes a little.

The air-bladders are left for some days in water, which is frequently changed, in order to remove the fatty and bloody particles; they are then withdrawn and cut lengthwise into sheets, which are exposed to the sun and air, the outer part being attached to boards. The inside, which is formed of layers of pure isinglass, is carefully detached from the exterior layers, wrapped in linen, and pressed, in order to keep it from contracting; it is then made up into parcels according to size. The parcels of isinglass of the large sturgeon are composed of from io to 15 sheets, and weigh about a pound and a quarter; those of the ordinary sturgeon contain 25 sheets, and weigh one pound. These parcels, to the number of 80 , are packed in a linen bag, covered with rush matting, and sent away sealed with lead; $38 \mathrm{lbs}$. are worth, at Astrakhan, from £I9 4s. to £28 I6s., according to quality. The air-bladder, although deprived 


\section{The Commercial Products of the Sea.}

of its internal parts, still contains a little isinglass, which is scraped off with a knife and kneaded; after being damped with water, it is made into small tablets about the size of a five-shilling piece. The sheets of isinglass of the Silurus glanis are placed like leaves in a book, and are dried upon small cords; it is made up into bags of $152 \mathrm{lbs}$. Carp isinglass (Cyprimus carpio) is made into parcels of 30 ; and, lastly, a good fish-glue is made at Astrakhan from the scales of the fish.

Vesiga is the name given to the dorsal cord or tendons of the vertebral column of the larger species of sturgeons, prepared in a certain manner, and much esteemed for the table: The quantity prepared reaches the value of $£ 20,000$ annually. It is first carefully washed and pressed to extract the soft matter which it contains, then dried and put up in packets the entire length, and folded in the middle. It is used chopped up in the preparation of small fish-cakes, much esteemed in Russia. The Russian poud of about $36 \mathrm{lbs}$. is worth $£ 2$ IOs. to $£ 33 s$.

The mode of preparation in Russia is as follows :The sound is taken from the fish while sweet and fresh, slit open, washed from the slimy sordes, divested of every thin membrane which envelops the sound, and then exposed to stiffen in the air. When the sounds of the cod or ling are prepared, the only difference is that they are slit open, washed in lime-water in order to absorb their oily particles, and then in clean water, when they are laid upon nets to dry. In the present Russian factories of the Caspian and Volga, the fresh sounds are first slit open, well washed to separate the blood and impurities, then spread out and exposed to the air to dry, with the inner silverywhite membrane turned upwards. This, which is nearly pure gelatine, is carefully stripped off, laid in damp cloths 
(or left in the outer covering), and forcibly kneaded with the hands. It is then taken out of the cloths, dried in the form of leaf isinglass, or rolled up, and drawn out in a serpentine manner into the form of a heart, horseshoe, or lyre (long and short staple) between three pegs, on a board covered with them; here they are fixed in their places by wooden skewers. When they are somewhat dried there, they are hung on lines in the shade, till their moisture is entirely dissipated. The oblong pieces are sometimes folded in the form of book isinglass. In order to obtain good isinglass, it is necessary to have well-arranged rooms to dry it in, as at Astrakhan. According to Pallas, at the lower parts of the Volga, a fine gelatine is boiled out of the fresh swimming-bladders, and then poured into all kinds of forms. In Gurief, a fine boiled fish-glue is prepared, perfectly transparent, having the colour of amber, which is cast into slabs and plates. The Ostiaks also boil their fish-glue in a kettle. The common cake isinglass is formed of the fragments of the other sorts; these are put into a flat metallic pan, with a very little water, and heated just enough to make the parts cohere like a pancake, when it is dried.

Indian Isinglass.-Attention was first directed to this product by Dr: Cantor, who stated that the suleah fish of Bengal, when at its full size, attains about four feet in length, and is squaliform, resembling the shark species in appearance, but exhibiting a more delicate structure. The flesh of the fish is exceedingly coarse, and is converted by the natives, when salted and spiced, into burtah, a piquant relish well known at the breakfast-tables of Bengal. The air-bladder of the suleah may be considered the most valuable part of it; this, when exposed to the sun and suffered to dry, becomes finely pellucid, and so hard that 


\section{The Commercial Products of the Sea.}

it will repel the edge of a sharp knife when applied to it. These bladders, when perfectly dried, vary in weight from half to three-quarters of a pound avoirdupois. This fish abounds in Channel Creek, off Saugor, and in the mouths of all the rivers which intersect the Sunderbunds they are exceedingly plentiful in certain seasons.

The discovery of isinglass as a product of India was so important that Dr. Cantor determined to investigate the subject, and to ascertain what were the fishes which yielded it. These seemed to be principally one or two species of Polynemus, especially the Polynemus sele of Hamilton's "Fishes of the Ganges," and the gol or gheriah (Corvinus niger). $P$. sele is supposed by Royle to be a variety of $P$. lineatus, which is said to be common on all the shores to the eastward. A larger species, $P$. tetradactylus, Shaw, is also believed to furnish some of the Indian isinglass. Several of the Siluridæ also afford it in large quantities, especially the species marked Silurus raita by Dr. Buchanan.

The kinds of fishes from which this useful substance has been obtained in India do not appear in all instances to have been correctly defined, for it has been suggested as derived from some which are destitute of air-vessels. Without entering too minutely into the subject, it may be stated that along the western coast, and down Malabar, the Siluroids are in the majority; but wherever large rivers debouch into the sea, there the Polynemi are captured. As we advance up to the eastern coast, at first the Acanthopterygians are in excess, whilst off Masulipatam, to the north again, the Polynemi become numerous, especially off the Sunderbunds. In Burmah, due to the character of the water, the Siluroids again obtain the predominance. Amongst the isinglass-producing Acanthopterygians, the Polynemi are most noted, but the species constituting this 
genus are peculiar, in having filamentous prolongations at the base of each pectoral fin ; these are remarkably elongated in Polynemus paradiseus, known in Bengal as the Tupsi mutchi or mango-fish. By correctly ascertaining the number of these prolongations in a specimen, a decision may be arrived at whether the species possesses or is destitute of an air-vessel; or, in short, if isinglass can or cannot be obtained from it.

But of seven species at present recognized in the seas and estuaries of the coasts of India, merely two are useful for this manufacture, and they are the only ones which have five pectoral appendages. Consequently, unless a large Polynemus possesses five of these filamentous appendages at the base of its pectoral fin, it will be useless looking for its air-vessel ; it has none, and isinglass cannot be prepared from it. When dried, the air-vessel is tongue-shaped, as are also those of others of the Acanthopterygians whose air-vessels are loose in the cavity of the abdomen, have no communicating duct leading to the pharynx, and are not attached to the vertebræ. If we examine the air-vessels of the Siluroid or scaleless cat-fishes, which are used for isinglass, we find them entirely different. They are like short rounded bags with an open mouth, this latter being where they have been torn away from their adhesions to the vertebræ. The fishes which furnish these descriptions of air-vessels are mostly found in muddy waters, estuaries, and the mouths of rivers, but do not thrive where the sea is clear. The Rita ritoides, C. and V., or Pimelodus rita, H. B., which attains a great size, and is found far up rivers, is said to afford this substance in large quantities.

Dr. McClelland discovered, about the year I839, that the Chinese had been importing isinglass from India in enormous quantities, and from immemorial ages, and an 


\section{The Commercial Products of the Sea.}

investigation was commenced into this subject. He ascertained that from one village, six miles south-east of Calcutta, from 800 to 900 maunds yearly, valued at from Rs. 25 to 40 the maund, were exported. Lord Auckland, when governor-general, sent some specimens to England as a new export, and, according to Dr. Royle, gave "a general . view of Indian fisheries, and the propriety of attending more extensively to the curing of fish." Dr. Royle, in I 842, in a pamphlet "on the production of isinglass along the coasts of India," gave a résume of what had been previously accomplished, as well as some very interesting figures and experiments on the value of this article, as received in London, both in an economic and financial point of view. "The sounds; when received fresh, are opened and stripped of the vascular covering and internal membrane, washed, and at once made into any form the manufacturer finds most convenient for packing. ... When dry, before it reaches the manufacturer (which is commonly the case, the fish being caught at a distance towards the sea), the sound has to be opened, and as much of the lining membrane as possible removed by the hand. A large earthen vessel is then filled with sounds, and water poured into it, and the whole covered up for I 2 hours, when the sounds will have been brought back to their original soft state, in which they may be as perfectly cleaned as if they had been obtained fresh." It seems more than probable that this will account for the fishy odour of this isinglass, as the sounds should be quite fresh when prepared. Dr. McClelland bleached his specimens in alum water (one ounce to four or five gallons), soaking them a short time, and, when saturated, removing them to a linen or cotton cloth, likewise saturated with alum water. In this they were tightly rolled up and set aside for 12 hours, the process being repeated until they 


\section{The Isinglass of Commerce.}

were white. Some were sprinkled or dusted with chalk, in case of exposure to damp in their homeward voyage; it can be easily rubbed off. At Gwadur the air-vessels were soaked in brine before being dried; but elsewhere they are simply removed and dried in the sun.

The lining membrane of the air-vessel of the sturgeon, as already noticed, yields the best isinglass, but it has been rejected in the Indian forms, which accounts for its more fibrous nature, although not proving that this lining portion in India is of the best. East Indian isinglass has some positive defects, such as retaining a fishy smell, besides being partially insoluble, perhaps due to some portions of the albuminous membranes remaining. In fact, it requires more care in its preparation, which should be undertaken whilst it is quite fresh; and greater caution is necessary in the drying process. If it be not properly dried, it might possibly undergo a slight change or decomposition, and become partially converted into a more insoluble form of gelatine. A more important objection is the smell, which, however, may likewise, to some extent, be traced to the preparation. Care should be taken that it is not contaminated by the animal fluid of the fish, for then it becomes very difficult to purify. Likewise, it is too thick, which may be obviated by beating or pressure, as is now done with some American and Brazilian kinds. "The extra labour that this would require," observes Royle, "could be profitably saved by not tearing it into fibres, in which form it is disapproved of in the market; but it might still be cut or rasped into a state fit for domestic use." The same authority likewise states that- "It is preferable, and will be cheaper, to prepare the article and send it as sheet isinglass, that is, in the form of the slit sounds themselves, or their purest membrane, washed, cleaned, and 


\section{The Commercial Products of the Sea.}

dried in the best manner. ... Isinglass cut into threads is unsuitable for the English market, because there is a great prejudice against purchasing wholesale, things in a cut and powdered state, in consequence of the innumerable methods adopted for falsifying and adulterating almost every drug."

The method adopted in separating isinglass from the fish-sounds and rendering it fit for market in India is as follows :-

The air-vessel is from 8 to 12 inches long, pointed at each end like a double nightcap, hollow, but without an opening. It is merely taken out of the fish when caught, and thrown aside without further trouble by the fishermen. It is at first soft and doughy to the feel, and partially distended with air; but in time it becomes collapsed and hard outside, in which state it is sold to the Chinese.

When fresh taken from the fish, it is covered by a thin cobweb of small blood-vessels, which are easily peeled off, as none of them enter the substance of the organ. Where this is neglected it is stained and spotted with blood, and the whole becomes hard and consolidated together, or the vascular membrane itself becomes putrid in places.

Hence the vascular membrane should always be carefully peeled off the first thing by the fishermen, when the outside will present an appearance like white satin, of a fine, oblique fibrous texture. The edge should now be slit open, and the same kind of bloody cobweb peeled from within. The inner side will then present the same whitesatin appearance as the outside, but, if attentively examined, will be seen to consist of transverse instead of oblique fibres. If it be allowed to dry, the whole becomes hard, horny, and partially transparent.

The thickness of the organ is about one-third of an 
inch, and the best way to see its fibrous structure is to tear it across when it is dry. In this way it splits in the direction of the transverse fibre, of which nine-tenths of its substance consists, the oblique fibre forming merely a thin coat outside. If the mechanical division of the transverse fibre be thus continued, the outer oblique coat becomes readily detached, and falls off in plates and scales from the outside. Thus, by mechanical means the organ may be separated into two very distinct parts-the first, or transverse fibre, consisting of perfectly pure gelatine, comprising about nine-tenths of the whole; the second, or oblique fibre, falls off in broad plates, consisting of albumen, thus leaving the gelatine or isinglass perfectly pure.

When cut open, cleaned, and dried as above, the suleahsound weighs from 12 to 16 ounces, from which 90 per cent. of pure isinglass may be separated by mechanical means.

The fish being caught at a distance from Bombay and Calcutta, the sounds are usually sold unopened and uncleaned, as taken from the fish, with the cobweb of bloodvessels hardened and dried upon the surface, which is frequently stained with blood.

In this state it requires to be soaked for 12 hours in water to overcome the horny consistence, so far as to be able to cut it open. The outer rind, being insoluble, is that on which soaking makes the least impression; so that when opened we frequently find much of the pure isinglass within dissolved; and if continued soaking and washing be practised after it is opened, with a view to soften and cleanse the outer insoluble rind, the article may become greatly impoverished and deteriorated from the solution of the inner parts, which thus become dissolved and washed away incautiously during the operation.

To obviate this it is only necessary to induce the 


\section{The Commercial Products of the Sea.}

fishermen to open the sounds at once when taken from the fish, and strip them of their cobweb, when they should merely be rinsed with a little fresh water and dried in the sun; after which the longer they are kept exposed to dry in the air, the better.

Brazilian Isinglass.-One or other of the siluroid fishes common in Guiana probably yields the Brazilian isinglass, which comes chiefly in the form of lump or pipe.

The fish which produce this article are caught annually in great quantities at the mouth of the Amazon. The isinglass is almost all sent to Great Britain. The fish caught in the rivers are not of first-rate quality. Great quantities of piracuru (Vastris gigas), highly esteemed by the natives, are taken on the Upper Amazon, and sent to the Para market.

A machorian, which gives $22 \mathrm{lbs}$. of salted or dried fish, produces about I lb. $1 \frac{1}{2}$ oz. of isinglass. Thus, the weight of the isinglass is to the fish as $\mathrm{I}$ to 20 , a rule found to be pretty general. According to the estimated take of fish, the yield of isinglass should be 123,480 lbs.

Supposing the price of isinglass to be but $2 s .6 d$. the pound (at Para it is $4 s$. and sometimes $5 s$.), and the price of salt fish a penny per pound, we have the following as the produce of the local fishery:-

$$
\begin{array}{llrr}
\text { Isinglass, } 123,480 \mathrm{lbs} . \text { at } 2 s .6 d . & \ldots & £ \mathrm{I} 5,435 \\
\text { Salt fish, 2,346, 120 lbs.., at } 1 d . & \ldots & 9,80 \mathrm{I} \\
& & £ 25,236
\end{array}
$$

From 750 to $880 \mathrm{cwt}$. of isinglass are shipped from Brazil annually, of the value of $£$ I 5,000 to $£ \mathrm{I} 6 ; 000$.

In the Cape Colony some of the wine merchants make use of the dried bladder of the kabeljauw (Sciana hololepidota, Cuv. and Val.) instead of isinglass. 


\section{The Isinglass of Commerce.}

West Indian Isinglass.-Under this name the isinglass obtained in British and French Guiana enters into commerce. It is the produce of one or two siluroid fishes. In British Guiana it appears to be obtained from the gilbackre or gilbagre (Silurus Parkerii), a fish very abundant in the estuaries of the rivers of the colony. A small quantity of this fish-glue, as it is termed, is now exported from thence.

In French Guiana some attention has also been given to the preparation of isinglass obtained from the machorian (Silurus felis), which is especially employed in the clarification of beer. Reduced into small shreds by the action of a mechanical plane, it dissolves completely in cold water, and is compared with Russian isinglass as two to three. Its cheapness gives it also advantages over the latter.

North American Isinglass. - Cod-sounds, which are brought in great quantities from Newfoundland, are nothing more than the salted air-bladders of these fishes. The Iceland fishermen, as well as those of America, prepare isinglass of a very excellent quality from cod-sounds, though they are not acquainted with the method of clarifying it which the Russians practise in preparing that article from the sound of the sturgeon.

Ribbon isinglass is obtained from the air-bladder of the common hake (Merlucius vulgaris), or probably from the fish passing under the name of hake on the coasts of America (Phycis chuss). The air-bladder is thrown into water to macerate for a little while, and taken out and pressed between two iron rollers, by which it is elongated to the extent of half a yard and more. It is then carefully dried, packed, and sent to market.

In the manufacture of ribbon isinglass from fish-sounds it is customary to place the softened and moist or 


\section{The Commercial Products of the Sea.}

macerated sounds between feed and compressing rollers, by which the viscid substance is compressed and joined, and formed into a continuous sheet. Notwithstanding the constant injection of cold water into the rolls, the substance adheres tenaciously to the roll, accumulates thereupon, and has to be cut away; so that the operation is slow and laborious, and productive of imperfect sheets.

Mr. James Manning, of Rockport, Massachusetts, has invented an improvement, designed to so strip the gelatinous substance from the rolls that the work may proceed continuously, the ribbon, as it is stopped, being again fed or guided by the operator into and between the rolls until sufficiently reduced or elongated for removal, or, for the action of other rolls, set nearer together to produce a thinner ribbon. He effects this result by placing at the side of each roll a scraper extending the whole length of the roll, having an edge set up to the roll, so that the roll shall run just clear of it, which scraper or cleaner strips from the whole surface of the roll the adhering gelatine in the form of a sheet.

Knowing that the sturgeon abounded in the North American rivers, and struck by the absence of isinglass from that quarter, in I85 I Professor Owen drew the attention of the Canadian Commissioner to the fact, and now a commerce has sprung up for this valuable product, which, previous to the first London Exhibition, had been rejected among the useless entrails of the sturgeon. Now some attention has been given to the preparation of the airbladder and the outer tunic of the alimentary canal, after the modes of obtaining the best Russian isinglass.

The sturgeon enters the rivers of North America, such as the Potomac, Delaware, Hudson, and Kennebec, in numberless quantities, like the shad and herring; but 
very little use is made of it. From Virginia up to the highest habitable northern latitudes, they ascend the rivers 300 to 500 miles up. From 30,000 to 40,000 sturgeons might be caught annually in the before-named rivers, and without counting the rivers farther north of Maine, the annual export of pickled sturgeon, caviare, and isinglass alone would be worth 500,000 dollars. The sturgeon is not, however, much esteemed in America; it brings scarcely twopence a pound in the market, and the roe and swimming-bladder are always thrown away. There are two species of sturgeon which frequent the American riversthe round-nosed (Accipenser rubicundus), which is generally eight feet or more long, and weighs over $200 \mathrm{lbs}$; and the sharp or shovel nosed (Scaphirhyncus platyrhyncus), which is seldom more than five feet long, and weighs about $150 \mathrm{lbs}$. or more. In Russia some are found which weigh $500 \mathrm{lbs}$, and in Norway one was caught which weighed Iooo lbs.

In the Hudson river thousands are captured annually - a number of persons making this their sole business. Immense nets are cast; but instead of hauling them entire, their floats are watched, and when one goes down a sturgeon is calculated on. The net is drawn at that point, his sturgeonship is hauled into a "scow," and the net is dropped again for a fresh victim. Inshore the fishermen have pens where the fish are kept for market. Lots of them go to Albany, where they are considered "tit-bits." Thousands of them are cut up and tried for the oil which they yield in abundance.

Chinese Isinglass.-Isinglass or fish-glue is very extensively employed in China for a great number of purposes. This substance, which is obtained in Europe by treating principally the swimming-bladder of the sturgeon, is made 
254 The Commercial Products of the Sea.

in China in another manner. There we meet in commerce with plates of a horny appearance, whitish, and of a tissue resembling animal membrane. These plates are of different forms, and bear in China the name of $j u-k a$. This substance, dissolved in water, forms a glue of an excellent quality, which is specially employed by cabinet-makers, furniture being an industry for which Ningpo is justly renowned. This glue has properties much resembling gelatine. Like gelatine, it is very nitrogenous, furnishing by distillation ammoniacal compounds and a bulky charcoal. This, incinerated, gives a whitish ash, composed probably of phosphate of lime.

In an industrial point of view it differs from isinglass by furnishing a glue of very considerable resistance. That of the best quality is reserved for the manufacture of furniture of the highest class, and is employed to unite pieces of wood which are required to resist great strain. Besides its industrial uses, this fish-glue is highly esteemed for food purposes by the Chinese.

The three kinds of fish chiefly used for obtaining isinglass in China are:-I. The My-yu (Scicna lucida), having greyish scales; 2. Ta-houang-yu (Otolithus maculatus), the head, fins, etc., of which are of a bright yellow; 3. Mung-pu (Anguilla (Muroena) pekinensis, Basilewski). To obtain the swimming-bladder the gills are removed, and by introducing the finger into the interior the airbladder is obtained. The intestinal and membranous parts which surround this organ are separated, and with a knife it is split longitudinally; the two lips are lifted, and a whitish membrane, which is found on each side, is taken out. In this state it is sold for food purposes. It is boiled a certain time in water, but does not dissolve, forming only a gelatinous mass of an insipid flavour. With the third- 
named fish, of the eel species, the belly is opened, and the organ, which is often of great size, removed.

The glue which is made is of excellent quality, but often yellow or grey tinted, according to the inferior quality of the substance employed. It is thus prepared:-The $j u-k a$ is washed in water for about two hours, then taken out and placed in a water-bath for a certain time. When, by the touch, it is found to be soft, it is removed and beaten with a heavy iron hammer. This is said to be a delicate operation, which should be done at the proper time. The substance is then flattened and rolled by the hand, and horizontal incisions are made, so that the air may more readily reach it and the drying be more rapid. When the glue is to be used, it is broken in pieces, put in a water-bath, with a little water to dissolve it.

It is probable if the Chinese isinglass were treated with sulphurous acid, a better commercial product might be obtained.

Besides its use for food purposes in China, isinglass is employed medicinally. That which is very transparent is most esteemed. It is usually met with in long, channelled pieces, transparent, of a dull yellow colour. Gelatine is often substituted for it, which is in long, opaque tablets, of a deep brown, and is made from the skins of different animals.

From the ports of Hiogo and Osaka, in Japan, the exports of isinglass to Shanghai and Hongkong were in-

$$
\begin{array}{ccccccc} 
& & & \text { Piculs. } & & & \text { Value. } \\
\mathbf{1} 874 & \ldots & \ldots & 2286 & \ldots & \ldots & \$ 75,212 \\
\mathbf{1} 875 & \ldots & \ldots & 6238 & \ldots & \ldots & \mathbf{1 9 8 , 4 1 6}
\end{array}
$$

In many of the French colonies it is stated that large quantities of valuable isinglass are lost to commerce from carelessness and ignorance. At Senegal and at Mahé the 
256 The Commercial Products of the Sea.

swimming-bladders are thrown away with the entrails. At Newfoundland they form part of the food of the seamen, and a few barrels are sent to France. From Cochin China a small quantity is shipped to China. From Cayenne 97.74 lbs., valued at $£$ I066, were shipped in 1874 . The average annual imports of isinglass into China were, in the five years ending I870, 2953 piculs of I $33 \mathrm{lbs}$., and in the five years ending 1875,3934 piculs.

Fish-Mares are the swimming-bladders or sounds of different fish, extracted and merely dried in the sun, and considered a great luxury by the Chinese, as possessing strengthening properties. They are extensively collected on the Malabar coast and shipped to Bombay, from whence large quantities are re-exported, principally to China and the Straits Settlements.

In the official year ending 1872,9008 cwts. of fishmaws and sharks' fins, valued at $£ 30$, I00, were exported from Bombay. From Penang 2277 piculs were shipped in I 870, and from Singapore I 25,946 cwt., valued at $£_{1}$ 3,7 I 7 . They often fetch as much as $£ \mathrm{I} 4$ the cwt. in the Canton market. 


\section{$(257)$}

\section{CHAPTER IX.}

\section{OTHER FISH PRODUCTS AND THEIR USES.}

Miscellaneous uses of parts of fishes-Scales of fish-Articles made from themSkin of fishes; applications of it-Shark skin-Ray skins-Shagreen and galuchat-Fish flour-Fish paste-Guianine, or pearl essence.

Some of the miscellaneous uses of parts of fish are curious. Thus, the serrated spine of the ray fish is used by the Indians of the Amazon to arm their arrows. In India the jawbone of the boalee fish (Silurus boalis) is employed by the natives about Dacca. The teeth being small, recurved, and closely set, act as a fine comb for carding cotton, in removing the loose and coarse fibres and all extraneous matters from the cotton wool. Sharks' teeth are used in arming weapons, and the teeth of sharks and other fish as trinkets. The jaws of the sleeper shark (Somniosus brevipinna) are used for head-dresses by the North American Indians. Fish bones are used by Indians and Eskimo in making implements ; sharks' vertebræ for canes ; the bones of the whale for weapons. Those of sharks and skates are used in Japan in making imitation tortoise-shell. Among the islands of the Corean Archipelago, the children use the dried spiral eggs of a species of skate or some other cartilaginous fish as rattles, having first introduced a few small pebbles to assist in making a noise. 
258 The Commercial Products of the Sea.

Scales of fish are composed of alternate layers of membranous laminæ and phosphate of lime, to which they owe their brilliancy. Perhaps the enamel or nacreous covering of the scales of fish generally is capable of being employed more largely in the arts; it appears to be sui generis, and seems hitherto to have escaped the scrutiny of organic chemistry.

At the Vienna International Exhibition, the scales of the captain fish (Heterotis), from Senegal, were shown, for making fish-glue to stiffen and glaze ribands.

The Royal University of Norway, Christiana, sent to the Smithsonian Institution, Washington, in 1875 , a diadem made from fish scales and eyes; and at the Paris International Exhibition of I 878 two Swedish exhibitors showed flowers and ornaments made of fish scales.

Parures and ornaments for ladies, made of fish scales, were at one time largely sold at the Crystal Palace, London.

At Newark, in the United States, large fish scales have been for some time industrially employed. The fresh scales are steeped for 24 hours in a solution of marine salt in order to clean them. They then undergo five or six washings in distilled water, which is renewed every two or three hours. Each scale is then separately dried with a clean cloth, and lightly pressed and left to dry. Finally, they are macerated for an hour in alcohol, and rubbed dry. They then appear like mother-of-pearl, and of a firm and elastic consistence. They are worked up either plain or coloured, for making artificial flowers, marquetry articles, and other fancy work. The Chinese have a mode of grinding up fish scales and using the powder as a dry pigment, to give a brilliancy to parts of pictures.

The skin of fishes is chiefly gelatinous, and is easily 
soluble in water; but some is of a firmer, stronger, and more useful character.

Although the skin of some marine mammals, such as those of the seal, walrus, and the white whale, or Beluga (known as porpoise leather), have long been commercially employed, it is only lately that attention has been more generally directed to the utilization of fish skins on an extended scale. Their employment hitherto has been very limited. Eel skins have been used for the thongs of whips and the attachments of flails, dried sole skins to clarify coffee, and some shark and ray skins by workmen to smooth and polish substances, and also to make a kind of shagreen leather.

At the Maritime Exhibition, held at the Westminster Aquarium in 1876, Mr. G. Kent, of Christiana, Norway, exhibited a variety of tanned skins, among which were :-

Whale skins tanned; the size ranging from 12 inches broad by 60 feet in length, suitable for wheel bands, for driving machinery, etc.

White fish, for upper leather, which can be prepared in pieces of 12 feet by 4 feet.

Skins of various flat-fish, dressed and prepared for gloves. Fine upper leather can be made with it, often to be had in sizes up to three feet square.

Skins of soles, dressed and tanned suitable for purses, etc.

Skins of thornbacks, suitable for cabinet-makers instead of sand-paper, and very much more durable.

Skins of eels, dressed and dyed suitable for braces and other purposes.

Mention is made of an industry carried on at Colborn, in Canada, with the skins of species of Siluroids for glovemaking, and this is to be prosecuted on a larger scale, both for the flesh for salting and the skin for currying. 
Shoes have been made in Gloucester, Massachusetts, from the skins of the cusk or torsk (Brosmus vuigaris), the use of which has been patented. If this material for shoes proves what it promises, it will open up a new market for fish skins, which will no doubt be highly profitable. In Egypt fish skins from the Red Sea are used for soles of shoes. In the Animal Products Collection at the Bethnal-green Museum, there are some tanned sole skins shown. The skin of the losh or burbot (Lota maculata), cleansed, stretched, and dried, is used by the country people in many parts of Russia and Siberia to trim their dresses, and instead of glass for the windows of their dwellings, being as transparent as oiled paper. It is also utilized by some of the Tartar tribes, as material for their summer dresses, and the bags in which they pack their animal skins. The inhabitants of the eastern coasts of the middle of Asia clothe themselves with the tanned skins of the salmon. It is asserted that it makes a leather as tough as wash-leather. The scale-marks give a very neat pattern to the leather.

W. Brozowsky, in his "Waarenkunde," Vienna, I869, under "Fish Skin," says this is obtained from the sea-angel (Squalus squatina, Lin.; Squatina lavis, Cuv.), the thorny shark (Squalus acanthias, S. carcharias), the tigered shark (S. caniculata), and some skates, as the angel skate (Raja rhinobatis), $R$. Sephen, etc. The skins of these skates and sharks have spines of different sizes instead of scales. The skins are used for polishing, and, after the star-formed spines have been smoothed down with sandstone, for covering boxes and cases, etc.

Guibourt (sixth edition, by Dr. G. Planchon, I870-7I, vol. iv.), says the sephen of the Red and Indian Seas, belonging to the genus Trygon, produces the tuberculous and hard skin called galuchat, after the name of a Paris 
workman who employed it first. The greater part of the Selacians, viz., the rousettes, sharks, humantins, aiguillats, leiches, etc., have a rough skin, which is used for covering boxes, and also for polishing wood. The greatest confusion exists among merchants as to the names given to the different skins. Each tradesman applies, according to his fancy, the name of peau de requin, peau du chien de mer, chagrin, and even galuchat. From specimens of the various skins, the following would seem to be the species utilized :-

I. Shark skin, from a young shark; small, imbricated scales, somewhat translucid, with longitudinal lines, the border or edge entire and circular. This edge is free on the body, but attached on the fins. This skin serves for covering cases, etc., but is not rough enough for polishing.

2. Skin of mottled rousette (Scyllium, Cuv.). Tuberculous, imbricated, horny, fine and hard scales, very near one to the other, and transparent, each triangular. Skin much used for polishing. Some persons state that "false galuchat" is made of it by rubbing off the scales, which leaves a square figure that becomes very showy when the skin is applied on a green paper. "I rather believe," continues M. Guibourt, "that the false galuchat is made with the skin of the aiguillat."

3. Peau de leiche (Scymnus), sold to cabinet-makers under the name of peau de chien de mer, is covered with nearly rhomboid, tuberculous, semi-transparent scales, arranged one near the other in quincunxes.

4. Peau d'aiguillat (Spinax acanthias, Cuv.).-Viewed with a magnifying glass, this skin appears covered with small square opaline scales, not rough like the preceding, but much used by the gainiers or sheath-makers, for its glossy nacreous aspect.

5. Pean de sagri (Spinax niger, Cuv.). Same uses as the 


\section{The Commercial Products of the Sea.}

preceding. The word sagri is Persian; sagher, Turkish, from its resemblance to the dressed leather made from the mule and ass, whence our word shagreen.

6. Galuchat or Sephen skin, from the back of the Hypolophus Sephen and Trygon Sephen, Cloq. It has numerous round tubercles, which become white by rubbing down, and in the interior opaque and nacreous. The skin is sometimes dyed different colours, but it is often preferable to leave it the natural colour by only half polishing it.

The quantity of ray skins, dried or salted, imported into France in $\mathrm{I} 863$ was about $\mathrm{I} 8,000 \mathrm{lbs}$. weight, principally from Portugal. Formerly they used to fetch as high as seven francs the pound; now they may be had for Is. a pound.

The best galuchat, or what we should call shagreen, is made from the skin of the sephen, which abounds in the Mediterranean Sea, and is also met with in the Red Sea and the Indian Ocean. This skin is remarkable for the size of the osseous protuberances. There are, however, two kinds of these rays, one with rough skin and the other with smooth.

From a certain portion of the skin of the angel shark (Squatina angelus) the Turks make the most beautiful sea-green watch-cases. These sharks, which form a connecting link between the genera of rays and sharks, are found in the Mediterranean principally, and the German Ocean sometimes. The skin, being very rough, is employed to polish wood and ivory, as well as for other uses in the arts.

Turners, ebonists, and carpenters in Europe use the rough skin of the blue dog-fish (Squalus glaucus, Lin.) like emery paper, for smoothing their work and preparing it for polishing. This shark skin is also used by the 
native workmen of the East for polishing wood and ivory, and it is made into shagreen. That most used now seems to be the skin of the ray (Hypolophus Sephen), which is very common on the Malabar coast, and an extensive commerce is now carried on in them in the Indian Ocean; they are found in the Sea of Oman, and also taken at Mahé. The house of Giraudon, I, Rue de Hasard Richelieu, Paris, makes excellent use of them for morocco and tabletterie. At the Paris Exhibition, I878, this firm exhibited two cases with numerous illustrations of the ornamental application of the prepared skin in large office-table inkstands, candlesticks, boxes and caskets, paper knives, reticules, card-cases, frames for photographs, bracelets, scent-bottles, etc. The long tail is also used for canes and penholders.

Peau de rousette (Squalus catulus and caniculus, Lin.). This fish, called chat at Marseilles, and crin in Catalonia, is smaller than the angel fish. The skin, reddish and without spots, is of a uniform grain, flat, and only used to make cases and other articles known as shagreen. These skins come from the Mediterranean, and are imported in bundles by the sailors, selling at from $30 s$. to $36 s$. the dozen, according to size.

Peau de chien de mer is another name given in France to some species of Squalus or requin. That usually found on the French coasts is known under the names of chien marin, chat marin, rousette tigrée (Squalus catulus, Lin.). Turners, cabinet-makers, and carpenters use the skin for scraping and smoothing their work before polishing; metalworkers and others also employ it. This skin, when worked up with the tubercules with which it is studded, takes the name of galuchat, and is ordinarily dyed green, to cover cases, sheaths, and boxes. Under the name of 


\section{The Commercial Products of the Sea.}

chagrin these skins used to be much employed in Turkey, Syria, Tunis, and Tripoli. That made in Constantinople was considered the best. It was coloured black, green, white, and red.

Fish Products.-The ingenuity of the Norwegians has discovered a hundred ways of pleasing the palate of the home consumer, and increasing the export of articles derived from the sea. Preserved fish and portions of fish, such as roes and sounds, salmon and lobster patties, or rather pasties or patés - for the first word gives an idea of something small, whereas these and other patés well known on the Continent resemble in size the famous venison pasties of the olden time in England, and are often a yard or more in length-preserved mussels, lobsters, prawns, and a dozen other articles, make up altogether a very considerable trade. Amongst the most peculiar preparations of Norway, however, are the fish flours-farines de poisson, as they are called. They are composed of the flesh of fish reduced to powder, with some additional substances, and the biscuits made from these flours are said by certain chemists to contain four times the nutritive matter of beef, and 16 times that of milk or rye bread. The farine de poisson is also used in place of rice and potatoes; and the dishes prepared from it are served at Norwegian tables with poultry, and are said to be very palatable.

Hard, horny pieces of dried bonito, called cummelmums, are rasped over their rice by the Hindoos. Dried loaves of putrid pounded fish are eaten in Africa and South America.

Fish paste.-A peculiar preparation, called by the Malays balachong and by the Javanese trasi, is a fœtid mass, composed chiefly of pounded or bruised fish and shrimps; this is fermented and dried in the sun. It is largely consumed as a condiment to rice in all the countries, 
to the east of Bengal, including the southern provinces of China and the islands of the Indian Archipelago. Its distribution gives rise to an extensive internal traffic, and, like the herrings and salt fish with the negro population of the West Indies, it forms to the natives a palatable addition to their ordinary food.

There is carried on, on the coasts of Cochin China, a considerable fishery for the preparation of a condiment or fish sauce, which is alleged to have very hygienic properties. It is there called "Nvoc-mam," and is made with shrimps and small fish which swarm on the banks of the coast during the months of May to August; these are slowly decomposed in salt. The most esteemed kinds are those of Tonkin and Phu-quoc. Of this sauce there are consumed in the six French provinces about 8,000,000 jars, valued at $2,000,000$ francs $(£ 80,000)$. This condiment is brought to perfection by being buried in the earth for several years. There is also made a fluid sauce, which is equal to the best anchovy. Nuoc-mam is an article of great necessity to the Annamites, who live in the midst of marshes, where the water is bad, and who neither drink wine nor spirits. Many of the French officers attribute the good health they enjoy while in Cochin China to the use of this fish paste.

A kind of pickle, called garum, is prepared in some countries of the East, of fish half putrified and strongly salted, with the addition of aromatics. Several species of garum were used by the Romans, which were made from the mackerel and the bonito.

The swimming-bladder of Argentina sphyrena, Lin., inhabiting the Mediterranean Sea, abounds in the silvery substance so remarkable in fishes, and is employed to form imitation pearls. 
266 The Commercial Products of the Sea.

The perfectly white solution of the scales of the bleak (Leuciscus alburnus), a fish indigenous to the rivers of France, is now used largely for the manufacture of artificial pearls. The solution or guanine is a mucus which lubricates the scales of the fish. It coagulates by heat to a thick, white deposit, and is obtained by carefully scraping the fish over a shallow tub containing fresh water. Care is taken not to scale the black or dorsal part, as these scales are yellow, while the white scales only possess value. The material is received on a horsehair sieve. The first water, mixed with a little blood, is thrown away. The scales are then washed and pressed, when the mucus or essence (guanine) sinks to the bottom of the tub and appears as a very brilliant bluewhite oily mass. It takes 40,000 fish to furnish two pounds of the material. The fishermen seal it in tin boxes with ammonia, and in this condition send it to Paris. If a drop of the essence be taken up by a straw and let fall upon water, it floats, giving forth the most brilliant colours. Glass bulbs, in the shape of pearls, lined with this substance, imitate the real gems with remarkable closeness. 


\section{$(267)$}

\section{CHAPTER X.}

INDUSTRIAL AND MANUFACTURING USES OF SHELLS.

Composition of shells-Variety of forms and colours-Various economic uses to which they are put-Extensive commerce in shells-Shell cameos-The cowry shells-Their various uses, as currency, for decoration, etc.-Shells worn for personal ornament-Wampum or treaty belts of shells-Shells as studies of design-British commerce in shells.

SHELLS, from their variety of structure and colour, and their singular beauty, have always formed a fruitful theme of description for the writer and the poet. The works of most of our best authors teem with lovely passages, many of which must occur to the memory of any general reader.

"Their exquisite, fragile, and beautiful forms

Are nursed by the ocean and rocked by the storms."

By young and old, savage and civilized, shells are alike admired and coveted, either for personal decoration, for the cabinet of the collector and the naturalist, or as simple ornaments in a room.

The uses to which shells are applied are more extensive than is generally supposed. The trade is growing year by year into greater importance; and there is ample scope yet for its extension with profit and advantage, alike to the merchant and importer; to the manufacturer and vendor, and to the general public who are the purchasers. 


\section{The Commercial Products of the Sea.}

To understand the composition of shells, a little preliminary scientific definition must be given. It has been observed that shells may be regarded as epidermal in their character, being formed upon the surface of a filmy cloaklike organ, called a mantle, which answers to the true skin of other animals. A slimy juice, consisting of a membranaceous tissue, consolidated by an admixture of carbonate of lime, exudes from the glands of this important organ, and, thickening in successive layers, becomes hardened and moulded on the body, at first simple and unadorned, but subsequently embellished according to the taste or inclination of the occupant. Each shell is therefore composed of animal and calcareous matter ; the first constitutes a membranaceous basis, which is equally curious and beautiful, being either formed of cells with hexagonal walls, or else of laminæ, more or less wrinkled, like morocco leather. Shells which are always concealed by the mantle are colourless; and those which are covered by the mantlelobes, when the animal expands, acquire a glazed or enamelled surface, like the cowries; when the shell is deeply immersed in the foot of the animal it becomes partly glazed, as in Cymba. In all other shells there is an outer layer of gelatinous matter forming what is called the epidermis, although it is sometimes very thin and transparent.

Woodward well remarks that the forms and colours of shells (as of other natural objects) answer some particular purpose, or obey some general law; but besides this there is much that seems specially intended for our study and calculated to call forth enlightened admiration. Thus the tints of many shells are concealed during life by a dull external coat, and the pearly halls of the nautilus are seen by no other eyes than ours. 


\section{Industrial and Manufacturing Uses of Shells. 269}

The variety in the figure, colour, and characters of sea shells is almost infinite. The most beautiful come from the Pacific and Australian coasts. The sun, by the great heat that it throws on the seas near the equator, would seem to have some effect in heightening the colours of shells produced in tropical zones, and the nature of the food of the animals probably gives them a lustre and a brilliancy which are wanting in those of colder latitudes.

It is impossible to enumerate all the purposes to which shells are applied, but some few may be specified.

The shells of Strombus, Triton, Dolium, Fusus, Murex, and Buccinum are used for fog-horns, trumpets, lamps, vases, and ornamental borders in flower gardens. Those of Busycon, Sycotypus, Mactra, etc., by Indians in the manufacture of implements. Shells of species of Mactra for ladles, scoops, and spoons, by fishermen. Those of Tridacna for vases, fountains, and in the manufacture of handles and carvings. The shells of Pecten, Haliotis, Dentalium, Mercenaria, etc., by the Indians for trimmings and ornaments. The scallop or palmer's shell (Pecten jacobaus) was used as a decoration of honour. Other Pectens are used in making pincushions and purses. The chank shell is used in the manufacture of Hindoo bangles, and in polishing or glazing cloth. The painter's mussel (Unio pictorum) is used to hold gold and silver colours. The shells of Placuna placenta are employed in China as a substitute for glass. Cytherea lusoria, the painted shell of the Japanese, with pretty designs on it, is used for playing a game. The cowries serve for currency in India and in the African trade, and for trimmings to various trappings. The shells of Mercenaria violacea, Purpura lapillus, and Buccinum undatum are used by the Indians of the eastern coast of America in the manufacture of their native money, and 
270 The Commercial Products of the Sea.

for modern wampum or shell beads for the Indian trade. The hyqua or Dentalium shells are employed in a similar manner by the Indians of the Pacific coast. The shells of Cyprea, Rotella, Oliva, Turretella, Phasianella (Venetian shells), etc., are mounted as buttons and jewellery. Composition shellwork for book-covers and frames is made by glueing various shells in mosaics. Calcined shells are used by dentrifice and porcelain makers. Cuttle-fish bone, from Sepia officinalis, has various uses. The opercula of some molluscs are used as "eye-stones," and polished and set for jewellery.

In considering the manufacturing and useful applications of shells, they might be conveniently ranged under the following groups:- I. The nacreous shells used for making pearl buttons and other useful and ornamental articles. 2. The pearly and iridescent shells, for ornamenting papier-mấché work, making card-cases, folios, jewel-cases, etc. 3. Various small shells used for making shell flowers and different fancy articles of grouped shells, and for ladies' bracelets, head-dresses, etc. 4. The shells used for carving cameos to set in brooches; bracelets, necklaces, scarf-pins, for studs and sleeve-links, and other articles of personal decoration. 5. Shells used for spoons, drinking-vessels, lamps, handles for knives, and other purposes of domestic economy; for snuff-boxes, pipes, and such like curiosities. 6. For making the purest kind of lime when calcined; for manure, in the form of shell sand and shell marl; and for making pottery-ware and a glaze or enamel, when crushed. 7. Shells are largely used for small monetary payments in North America, India, and Africa, and also as counters in games of chance. Lastly, they serve as studies of design, form, and colour for the sculptor, painter, and art manufacturer. 
Industrial and Manufacturing Uses of Shells. 271

There are other uses besides the foregoing, but at least these are the principal ones.

Let us pass on now to speak first of the shells used for carving cameos, and those employed to form articles of personal decoration.

Of the quantities imported for this purpose we can obtain no reliable details. The shells come over in bags, and every now and then the City brokers announce a sale of bull's mouth, helmet shells, queen conchs, etc., but no aggregate records are kept of the numbers.

To show, however, the extent of the trade in shells, here are the particulars of the sales advertised on one day in London (October Ioth, I87I), by various City brokers:By Lewis and Peat-

275 cases Bombay M.O.P.*
43 " Egyptian ",
6 ", Gambia ",
262 ", Panama ",
45 ", of cowries
8 I packages fancy shells
195 cases Japan ear shells.

By Ellis and Hale-

140 cases and 6 casks of M.O.P. from Fremantle.

8 , and 27 serons M.O.P. Bombay.

$211 "$ cases of cowries.

24 tons of Japan ear shells.

By Price, Hickman and Co.-

I8 cases Bombay M.O.P.

By Bowyer and Bartlett-

4I cases M.O.P.

6000 conch shells.

1400 helmet shells.

* The trade abbreviation for mother-of-pearl. 


\section{The Commercial Products of the Sea.}

By Brooks and Faith-

84 baskets, 13 bags, and 10,000 loose green snail.

230 packages and to tons of loose Japan ear shells. 12,000 turbos.

By Donald Gray and Sons-

39 cases Manila and $5 \mathrm{I}$ cases Bombay M.O.P.

I case red shank shells.

By John Griffin and Son-

194 cases Bombay M.O.P.

$38 \mathrm{r}$ bags Maldive cowries.

5 tons Japan green ear.

Most of the univalve shells are of the character called porcelanous, from their brittleness, translucence, and the resemblance of their fracture to that of porcelain. But this fracture, when examined by a microscope, reveals a structure of thick parallel layers, usually of a fine fibrous nature, at right angles to the external surface. The soluble part of these shells is carbonate of lime, the particles of which are cemented together with.a very minute proportion of animal mucus. The hard and compact nature of such shells, and their generally smooth surface, prevent their being cut by the ordinary tools which are available for the less hard and frangible nacreous shells; it is, therefore, necessary to treat them with emery, rotten-stone, and other substances harder than themselves.

Such shells generally require rather to be polished than cut, but where it is necessary to divide them, in order to exhibit their sections, they are operated upon by means of the slicer with diamond powder.

Certain description of these shells are well adapted for cameo-cutting, from their substance being made up of differently coloured layers, and also from a difference of hardness and texture in the various layers, some approaching 
Industrial and Mamufacturing Uses of Shells. 273

more nearly to the nature of nacreous than of porcelanous material.

The word cameo, derived from an Arab word, signifying bas-relief, was originally restricted to hard stones, such as onyx, sardonyx, etc., engraved in relief; but the name has since been extended to gems cut on shell, lava, and other substances.

The good workman always carefully puts his work on the shell in such a manner that the direction of the laminæ of the central coat is longitudinal. In cameos the central layer forms the body of the relief, the inner layer being the ground, and the outer the third or superficial colour, which is sometimes used to give a varied appearance to the surface of the figure. The cameo-cutter selects from the shells which have the three layers:-I. Those which have the layers strongly adherent together, for if they separate his labour is lost; 2. Those in which the middle layer is thick; 3. Those in which there is a good distinction of colour between the layers; and 4. Those in which the inner layer is of the colour suited to his purpose.

The kinds now employed, and which experience has taught him are best for his purpose, are-I. The bull's mouth (Cassis rufa), which has a red inner coat, or what is called a sardonyx ground. The shell is red with several series of thick knobs, the outer lip deep yellowish red. 2. The black helmet (C. Madagascariensis), which has a blackish inner coat, or what is called an onyx ground, and shows up white upon a dark claret colour. The shell is often nearly a foot long. 3. The horned helmet ( $C$. cormuta), white with an orange yellow ground; and 4. The queen conch (Strombus gigas), with a pink ground. This shell is about Io inches long, aperture rose-coloured, lip extremely broad, rounded above. S. pugilis, another species, 


\section{The Commercial Products of the Sea.}

is a turbinate shell, reddish and yellow, lip rose-coloured without and striated. The bull's mouth and black helmet are the best shells, for the horned helmet is apt to separate from the ground, or to "double," as the French workmen call it; the queen conch has the two colours seldom distinctly marked from each other, and the pink of the ground flies by exposure to the light. The red colour of the bull's mouth only extends a small distance in the mouth of the shell, becoming paler as it proceeds backward, as may be observed by the pale side generally to be seen in such red-grounded cameos. Hence, the bull's mouth affords only a single cameo large enough for a brooch, and several small pieces for shirt-studs, while the black helmet furnishes on an average about five brooches and several stud-pieces. The queen conch yields only a single good piece. Cassis flammea, about six inches long, and $C$. decussata and $C$. tuberosa, white upon a dark claret colour, are occasionally used.

The bull's mouth shells are brought from India and Ceylon, the black helmets and the queen conchs from the West Indies, and all are supplied through the London market.

Shell cameos, some years ago, were a good deal in fashion; and even now a well-executed, artistic Roman shell cameo is an elegant work of art. Genoa and Rome are the seats of the best work, although many common ones are cut in France. In Rome there are about 80 shellcameo cutters, and in Genoa 30, some of whom also carve in coral. The art of cameo-cutting was confined to Rome for upwards of 40 years, and to Italy until the last 26 years, at which time an Italian began cutting cameos in Paris, and now over 3000 persons are employed in that city. 


\section{Industrial and Mamufacturing Uses of Shells. 275}

The black helmet, on account of the advantageous contrast of colour in the layers, produces very effective cameos, the carved figure of the white upper layer being strongly relieved by the dark, almost black, ground supplied by the second layer. The shell is first cut into pieces, the size of the required cameos, by means of diamond dust and the slitting mill, or by a blade of steel fed with emery and water.

It is then carefully shaped into a square, oval, or other form on the grindstone, and the edge finished with oilstone. It is next cemented to a block of wood, which serves as a handle to be grasped by the artist while tracing out with a pencil the figure to be cut on the shell.

The pencil mark is followed by a sharp point, which scratches the desired outline, and this again by delicate tools of steel wire, flattened at the end and hardened, and by files and gravers, for the removal of the superfluous portions of the white enamel. A common darning-needle, fixed in a wooden handle, forms a useful tool in this very minute and delicate species of carving. The careful manipulation necessary in this work can only be acquired by experience; the general shape must first be wrought, care being taken to leave every projection rather in excess, to be gradually reduced as the details and finish of the work are approached. To render the high parts more distinct during the process of carving they are slightly marked in black.

Throughout the cutting, great caution must be observed that in removing the white thickness the dark ground is not damaged, for the natural surface of the dark layer is far superior to any that can be given artificially; indeed, should the ground be broken up at one part, it would be requisite to remove the entire scale or lamina from the 


\section{The Commercial Products of the Sea.}

whole surface-a process very tedious, and much more difficult than separating the white from the black. In order that the finished cameo may possess a distinct outline at all points of view, it is desirable to adopt the system followed in antique cameos; namely, to leave all the edges of the figure quite square from the ground, and not gradually rounded down to the dark surface. Should this latter method be followed, it will be found that the outline is in many places undefined, owing to the colour of the white raised figure of the cameo gradually emerging into that of the dark ground ; this evil is entirely avoided by leaving the edge of the figure quite square for the thickness of one-fiftieth of an inch.

The surface of the cameo should be finished as nearly as possible with the cutting tools, as all polishing with abrasive powders is liable to remove the sharp edges of the figures and deteriorate the cameo by leaving the form undefined. When, however, the work has been finished as smooth as possible with cutting tools, the final polish may be given by a little putty-powder used dry, upon a moderately stiff brush, applied with care, and rather to the dark ground than to the carved surface; this is the concluding process, after which the cameo is ready for removing from the block prior to mounting.

The various styles in which they are mounted depends a great deal upon the country where they are to be worn.

At the various international exhibitions which have been held, some very fine examples of Roman shell-cameo cutting have been shown. At the Dublin Exhibition in I865, Giuseppe Saulicini, of Naples, exhibited excellent samples of artistic workmanship, priced at from $£_{2}$ to $£_{4}$ each, representing, among others, Night and Day, the Virgin and Child, after Carlo Dolce; Flora, from the 


\section{Industrial and Manufacturing Uses of Shells. 277}

antique; Bacchanals, from a fresco found at Pompeii; Peace, Medusa, Aurora, Ceres, and other subjects. Giuseppe Tari showed cameos with the figures of St. Paul, St. Peter, Michael Angelo, and Galileo. Luigi Saulini, of Rome, also showed 18 fine shell cameos. At the Naples Maritime International Exhibition, Domenico Pascoli, of Rome, received a first-class silver medal for work on shell cameos. At the Paris Exhibition of 1878, Francati and Sante Maria, of Rome, showed some fine cameos carved on various shells, and parures and ornaments made from the pink-mouthed conch (Strombus gigas). A fraud is frequently"practised by cutting away the engraved part of old shell cameos, and attaching this to a base of agate, by which an appearance of onyx is obtained.

Solid round beads are turned from the cameo shells and threaded for bracelets. Bracelets and sleeve-links are also made of the polished pearly Trochus or Venetian shells of commerce.

The shells of the cowry family next claim our attention, -a most extensive genus, distinguished, if not for their elegance of form, yet for beauty and variety of tints and richness of polish. This polish is preserved by the animal, while alive, enveloping the shell in the mantle or membranous fold. They are in general smooth, glossy shells, of great brilliancy of colour, and elegantly marked with dots, zigzag lines, undulations, stripes, and so forth. They are all, excepting the small British cowry, natives of the seas of warm climates. Many of them are very highly prized by collectors, and several are turned to use for ornamental purposes.

The species of cowries principally used for bracelets, sleeve-links, or brooches and small charms, are Cyprea undata, C. felina, C. asillus, C. ziczac, C. cribarea, and $C$. 
278 The Commercial Products of the Sea.

reticulata. Cameos are sometimes traced on the back of the blue-back cowry (Cyprea moneta), and when linked together make very neat bracelets. Cowries are sometimes used for making an enamel for clock-faces and a glaze for plates.

Cowries are largely dealt in for exchange purposes, and are shipped in quantities to West Africa. They are chosen for their bright enamel, small, even size, and not being mixed with spurious shells. Maldive cowries fetch from I $2 s$. to $35 s$. the cwt.; Dacca and Cuttack cowries, $6 s$. to 22s. $6 d$. the cwt.; but common blue and dead shells, that is, those with no gloss or enamel, are only worth $3 s$. $6 d$. to I $5 s$. the cwt.

Cowries form no inconsiderable item in trade, two of the smaller white species being collected for use as a circulating medium, the true money cowry (Cyprea moneta) and the false or ring cowry ( $C$. annula) passing current in many parts of Africa as mediums of exchange. One Hamburg house sends annually I4 vessels to Zanzibar for cargoes of cowries, with which they proceed to the rivers on the west coast of Africa, and purchase cargoes of palm oil or other produce. The following shows the imports of cowries into the port of Lagos alone, and a duty is levied on them of one shilling per cwt. :-

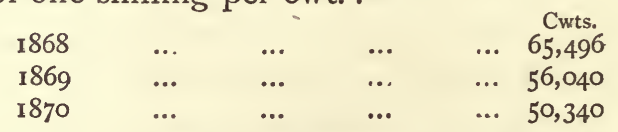

Their relative currency value varies in different localities. In British India about 4000 pass for a shilling, and the erection of a church, which cost $£ 4000$, is said to have been paid for entirely with cowries. The ordinary gradation or value on the West coast of Africa is as follows :-

$$
\begin{aligned}
40 \text { cowries } & =\mathbf{I} \text { string. } \\
2 \frac{1}{2} \text { strings } & =\mathbf{I} d \text {. } \\
100 \text { cowries } & =\mathrm{I} d \text {. }
\end{aligned}
$$




$$
\begin{aligned}
50 \text { strings } & =\mathrm{I} \text { head of cowries. } \\
\text { Io heads } & =\mathrm{I} \text { bag. } \\
2000 \text { cowries } & =\mathrm{I} \text { head. } \\
3 \text { heads } & =\mathrm{I} \text { dollar. } \\
20,000 \text { cowries } & =\mathrm{I} \text { bag. }
\end{aligned}
$$

In other places they are valued at about Is. $3 d$. the Iooo. Sometimes 60,000 to 100,000 (or from $£_{3}$ I 5 s. to $£ 7$ IOs.) are given for a young wife, whilst a more common or ordinary wife may be had for 20,000 cowries, or $25 \mathrm{~s}$. In Sudan, much as the people trade, they have no other currency than the cowry, of which 2000 shells, weighing from five to seven pounds, are worth only one dollar. Since the recent expansion of traffic in that country, the cowry currency is already becoming an almost intolerable burden, which operates as a powerful check to the prosperity of the people. Although completely depreciated in the territory of the Upper Nile, cowries still form among the Mittoo tribes, between $5^{\circ}$ and $6^{\circ} \mathrm{N}$. lat., a favourite ornament.

One of the most common and at the same time one of the most beautiful species, the tiger cowry, is frequently cut for snuff-boxes, made into ink-holders and ring-stands, salt-cellars, etc., and has frequently the Lord's Prayer or sentences engraved on it. They are often mounted as punch-ladles and spoon-bowls, made into whistles and other fancy articles, and shaped into grotesque imitations of animals.

The skin jacket worn by some of the Bornean tribes in war is ornamented with small shells placed over one another, like scales or links in a coat of armour. The Dyaks stick small white money cowries in the eye-sockets of the skulls of their enemies, which they keep; they look like a closed eye. In India these shells are much used to ornament the trappings of horses and elephants, and many of these cowry bands may be seen in the India 


\section{The Commercial Products of the Sea.}

Museum. Cowry shells are also strung like beads, or sewed like buttons on their dress by Brinjari women as personal ornaments, and are in circulation as money in the Hyderabad State, and in other parts of the country.

The valuable cargoes of sandal-wood obtained in some of the Pacific Islands for the China market are, in the first instance, purchased from the New Hebrides by means of a shell-the Ovulum angulosum, a white porcelanous variety of cowry with a violet-coloured lip-which is found in the Friendly Islands, but never in the sandal-wood region. This shell is so highly esteemed as an ornament by the natives of the New Hebrides, that for one shell they will give in exchange a ton of sandal-wood. The trading captains go expressly to the Tongan Archipelago for the shells, where they sell at a Spanish dollar each.

As objects of decoration, certain shells have always been in great demand among savage and semi-civilized peoples.

A substance pleasing to the eye, and easily worked, such as is offered by nature in the shells of marine and fresh-water molluscs, could not fail to attract the attention of men in the earliest times. The love of personal adornment, moreover, already manifests itself in the lowest stages of human development, and shells being, above other natural productions, particularly fitted to be made into ornaments, it is not surprising that they were employed for that purpose in all parts of the world. The North American tribes made an extensive use of the shells of the seacoast as well as those of their rivers, and fossil marine shells were also employed as ornaments. The valves of recent marine molluscs, indeed, must have been widely circulated by barter, considering that they are found, in the shape of ornaments, and sometimes of utensils, in the 


\section{Industrial and Manufacturing Uses of Shells. 28 I}

interior of North America, at great distance from the shores of the sea.

Many tribes of North American Indians used to wear necklaces of shell beads, which served as money. They were called wampums. Those on the Atlantic side were made of the clam shell (Venus mercenaria). Those made from the internal purple part of the shell of Mercenaria violacea, Schum, Venus mercenaria, Lin. and Lam., werè most esteemed, constituting the searvan or wampum, the specie currency of the natives. Six of the former (blue) and three of the white were equivalent to an English penny. The Dentalium, or tooth-shell, was another monetary tender of the natives of the north-west coast of America, known under the name of sarquo. It is a milk-white, round shell, of extreme hardness, resembling the shank of a common clay pipe. It varies in length from one to four inches, and is about half an inch thick, hollow, slightly curved, and tapering a little towards the ends. They were valued in proportion to the number that, when ranged on a string passed through their hollow tubes, extended a fathom in length. Forty to the fathom was supposed to be the fixed standard of excellence and worth. Thus, their currency value was, in the fur regions-

\begin{tabular}{|c|c|c|c|}
\hline to she & xtending I fathom & & $\begin{array}{l}\text { Beaver skin. } \\
\ldots \ldots \\
\text {. }\end{array}$ \\
\hline $\begin{array}{ll}39 & , \\
38 & , "\end{array}$ & ", ", & $\ldots$ & $\begin{array}{ll}\ldots & 2 \\
\ldots & 3\end{array}$ \\
\hline
\end{tabular}

These shells abound in certain places of the Pacific coast; being open at both ends, they can be strung without further preparation. They have been found in the interior of the country, far from the Pacific coast, as personal ornaments of existing tribes, and even in the ancient mounds of Ohio. The latter fact, indeed, is of great interest in its bearing on the extent of former 


\section{The Commercial Products of the Sea.}

aboriginal trade-religions, the distance from the Pacific to the State of Ohio being almost equal to the whole breadth of the North American continent. The Dentalium is also found in the West Indies. If it should likewise occur on the southern coasts of the United States, there is at least a possibility that the specimens found in Ohio may have been obtained from the last-named region.

The term "wampum" is often applied to shell beads in general, but should be confined to a certain class of cylindrical beads, usually one-fourth of an inch long and drilled lengthwise, which were chiefly manufactured from the shells of the common hard-shell clam (Venus mercenaria, Lin.). This bivalve occurring, as every one knows, in great abundance on the North American coasts, formed an important article of food of the Indians living near the sea, a fact demonstrated by the enormous quantity of cast-away clam shells, which form a considerable part of North American kjoekkenmoeddings. The natives used to string the molluscs and to dry them for consumption during winter. The blue or violet portions of the clam shells furnished the material for the dark wampum, which was held in much higher estimation than that made of the white part of the shells, or of the spines of certain univalves. Even at the present time places are pointed out on the Atlantic sea-board-for example, on that of Long Islandwhere the Indians manufactured wampum, and such localities may be recognized by the accumulations of clam shells from which the blue portions are broken off. Wampum beads formed a favourite material for the manufacture of necklaces, bracelets, and other articles of ornament, and they constituted the strings and belts of wampum, which played such a conspicuous part in Indian history. Loskiel makes the following statement in reference to wampum :- 
Industrial and Manufacturing Uses of Shells. ${ }_{283}$

"They made some of shells, which they highly esteemed, but they manufactured them very rarely, because this labour required much time for want of the proper tools; and the beads, moreover, were of a rude and clumsy appearance. Soon after their arrival in America, the Europeans began to manufacture wampum from shells, very neatly and in abundance, exchanging it to the Indians for other commodities, thus carrying on a very profitable trade. The Indians now abandoned their wooden belts and strings, and substituted those of shell. The latter, of course, gradually declined in value, but, nevertheless, were and still are much prized."

The great value attached to wampum as an ornament is well illustrated by the following passage from the work of Roger Williams, who emigrated to North America in I63I :- "They hang these strings of money about their necks and wrists, as also upon the necks and wrists of their wives and children. Mâchequoce, a girdle; which they make curiously, of one, two, three, four, and five inches thickness and more, of this money, which (sometimes to the value of $£$ Io and more) they wear about their middle and as a scarfe about their shoulders and breasts. Yea, the princes make rich caps and aprons (or small breeches) of these beads thus curiously strung into many formes and figures; their blacke and white finely mixt together." The wampum belts, so often mentioned in connection with the history of the eastern tribes, consisted of broad straps of leather, upon which white and blue wampum beads were sewed in rows, being so arranged that by the contrast of the light and dark colours certain figures were produced. The Indians, it is well known, exchanged these belts at the conclusion of peace, and on other solemn occasions, in order to ratify the transaction and to perpetuate the remem- 


\section{The Commercial Products of the Sea.}

brance of the event. When sharp admonitions or threatening demonstrations were deemed necessary, the wampum belts likewise played a part, and they were even sent as challenges of war. In these various cases the arrangement of the colours and figures of the belts corresponded to the object in view: on peaceable occasions the white colour predominated; if the complications were of a serious character, the dark prevailed; and in the case of a declaration of war, it is stated the belt was entirely of a sombre hue, and, moreover, covered with red paint, while there appeared in the middle the figure of a hatchet executed in white.

Large quantities of shell ornaments, mostly destined to be strung together or to be worn as pendants, have been found in the sepulchral mounds and other burial-places of the Indian race. In Ohio, according to Messrs. Squier and Davis, beads made of shell and other materials occur even more frequently in the sacrificial mounds than in those of a sepulchral character, a circumstance that may be accounted for by the value attached to those objects by their owners, who deemed them worthy of being offered in their sacrificial rites. The methods employed by the manufacturers doubtless being of the most primitive character, each shell bead was the result of a certain amount of patient labour, and consequently was esteemed according to the time. and art bestowed on its production.

The Indian shell ornament in its simplest form consisted of entire specimens of small marine univalves, such as Marginella, Natica, and Oliva, which, after being conveniently pierced, could be strung together at once without further preparation, and worn as necklaces, etc. The abovementioned kinds were met by Squier and Davis in the mounds of Ohio, and in opening the Grave Creek mound 


\section{Industrial and Manufacturing Uses of Shells. 285}

500 specimens of Marginella were obtained near one of the skeletons. Yet the number of entire sea-shells employed as beads by the natives appears insignificant, when compared with the enormous quantity of objects of the same class which they manufactured from fragments of the valves of marine and fluviatile shells. These wrought beads exhibit various forms and sizes, but are mostly found in the shape of more or less regular sections of cylinders, pierced through the centre.

They are often proportionately thick, but sometimes rather thin, resembling the small bone buttons of commerce. Most of them are small, not exceeding six or seven millimètres in diameter ; the largest species, however, have a diameter of no less than 28 millimètres.

The largest, and therefore the most esteemed, beads and pendants were made by the Indians from the columelle, or, as Cabeça de Vaca expressed it, from the "hearts," of large conchs, among which the Strombus gigas seems to have been most frequently used. These beads are more or less cylindrical or globular, and always drilled lengthwise. Some are tapering at both ends, resembling a cigar in shape, and were two and a half inches in length. The aborigines also made from the columelle of large marine univalves peculiar pin-shaped articles, consisting of a more or less massive stem, which terminates in a round knob.

Calcined shells furnish the purest lime, and it is the kind which, under the name of "chunam," is so largely used in the East as an ingredient with the areca-nut and betel-leaf masticatory.

For the purpose of the agriculturist, shell-sand and shell-marl, when obtainable, are highly valuable as fertilizers; and crushed shells are used for covering the pathways in our parks and the walks in our gardens, for making fine pottery, and other purposes. 
Lastly, the uses of shells as studies of design, form, and colour to the sculptor, painter, architect, and art manufacturer, may be seen in various parts of the South Kensington Museum.

Lamarck long ago recommended to the attentive study of the architect the extreme diversity of the protuberant parts on the surface of shells, as well as the regularity and elegance of their distribution. There is no possible form of which nature does not offer examples. Architecture would find in many of the species of the genus Cerithium, even to those of Pleurotomis and spirals, a choice of models for the adornment of columns, and these models would be found very worthy of being employed.

Shells were the favourite objects of ornamentation of the older wood-carvers, as evidenced in the fireplaces of many ancient mansions. The famous garoon pattern, so much used formerly by silversmiths, is said to be derived from the edge of the trumpet shell (Triton femorale), which is called the garoon shell.

There are many other industrial uses of shells, but those enumerated may be considered the principal ones.

Mother-of-pearl, and other nacreous shells, will be noticed in a separate chapter.

The aggregate value of the imports of foreign shells, in the last few years, may be taken at $£ 250,000$. It is somewhat difficult to arrive at any correct estimate on this subject, because shells are scarcely particularized in the Board of Trade returns. Classified under the head of raw materials which come in "duty free" for the use of manufacturers, the officials are very indifferent as to the nature of the imports; and thus we have no account of the rough cameo shells, the snail and ear shells, the Murices, and others which are received in large quantities. When shells 
Industrial and Mamufacturing Uses of Shells. 287

were subject to an import duty, varying from 5 to 20 per cent., it was necessary that the entries should be more specifically detailed.

Large quantities of shells, which are used for different manufacturing purposes, come in under the broad, general heading of "specimens of natural history." The only specific mention of shells in the Parliamentary trade returns are mother-of-pearl, cowries, and cameos unset, besides pearls,- the well-known and valued product of the pearl oyster.

The imports and value, as far as officially stated, in I870 were :-

$$
\begin{aligned}
& \text { Mother-of-pearl, 26, 197 cwts. ... } \quad \ldots \quad £ 76,489 \\
& \text { Cowries, } 6118 \text { cwts. ... } \quad \ldots \quad \ldots \quad \ldots \quad 6,347 \\
& \text { Cameos, not set } \quad \ldots \quad \quad \ldots \quad \ldots \quad 3,445 \\
& \text { Miscellaneous shells for collectors, dealers, } \\
& \text { Pearls } \\
& \text { and manufacturers, about ... }
\end{aligned}
$$

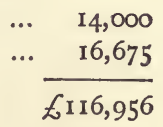

These figures were much below the average.

The use of shells is not restricted to this country. They are employed for manufacturing purposes in China and India, in France, Italy, Germany, and other parts of the continent of Europe, and also in North America; so that the subject we have been considering takes larger proportions than at first sight would appear. 
288 The Commercial Products of the Sea.

\section{CHAPTER XI.}

INDUSTRIAL AND MANUFACTURING USES OF SHELLSContinued.

Shell bangles or bracelets, made from the chank or Turbinella species-Religious veneration for the shell-Process of manufacture-The bangles described-Great clam shells used as benitiers-The queen conch, large importations of-Uses of nacreous and iridescent shells-Utilization of shells for economic purposes-Shell utensils-Shell flowers-Shell trumpetsShell pipes-Pulverized and calcined shells-Ornamental uses of opercula -Dyes from the mollusca-Tyrian purple-Marine silk.

Shell Bangles or Bracelets.-Under the commercial name of chanks, the large white, concave, heavy, porcelaneous FIG. I9.

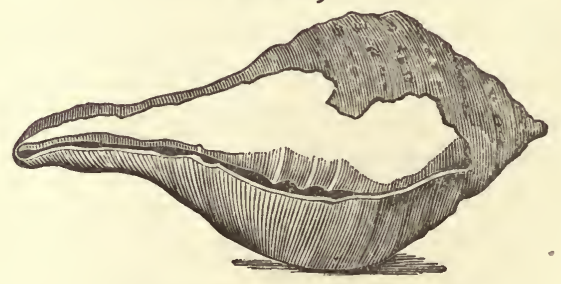

Chank shell (Turbinella pyrum).

shells of the Turbinella pyrum, Lam., the Voluta gravis, Lin., and T. rapa, are much prized in India. The shell is ventricose above, pear-shaped, fulvous white, with reddish spots in young individuals. 


\section{Industrial and Manufacturing Uses of Shells. 289}

The shankh or chank is the sacred shell of the Hindus, and the national emblem of the kingdom of Travancore. The god Vishnu is represented as carrying a chank shell in one hand, and a chakra in the other.

The Hindus believe that unless they worshipped this shell at the commencement of every worship or prayer, their offerings would not be accepted. Vishnu, the Protector, is supposed to hold a chank in his hand. It is called Devadatta. Shankar, the Destroyer, according to mythology, possesses a like shell. The first incarnation of Vishnu, called Machhávatár (which literally means transformation into fish), was undertaken for destroying Shankhásura (the giant chank shell), in order to regain the Vedas, he having stolen them and taken refuge under the ocean.

The fishery for these shells is principally carried on in the Gulf of Manaar, in the vicinity of Ceylon, and on the coast of Coromandel, at Travancore, Tuticorin, and other places, the shells being brought up by divers in about two or three fathoms of water. Those taken with the animal in, and called green chanks, from having the epidermis on, are most in demand. The white chanks, or dead shells thrown upon the beach by strong tides, having lost their enamel, are scarcely worth the cost of freight to Calcutta. The number obtained varies considerably in different years, according to the weather and the success attending the divers. Frequently $4,000,000$ or $5,000,000$ of these shells are shipped in a year from the Gulf of Manaar. In some years the value of the rough shells, as imported into Madras and Calcutta, reaches a value of $£ 10,000$ to $£ 15,000$. A few hundreds are occasionally imported into Calcutta from the Arabian and Persian Gulfs. The chank fishery of Ceylon at one time employed 600 divers, and yielded a 
revenue to the island government of $£ 4000$ per annum for licenses. The fishery is now free.

These shells are often used as oil vessels or lamps in Indian temples, for which purpose they are carved and sculptured or otherwise ornamented. When the volute turns to the right, the shell is held in peculiar estimation -a right-handed chank being so highly prized for its rarity as sometimes to sell in Calcutta for its weight in gold, or at from $£ 40$ to $£ 50$. In Ceylon also, the reversed

FIG. 20.

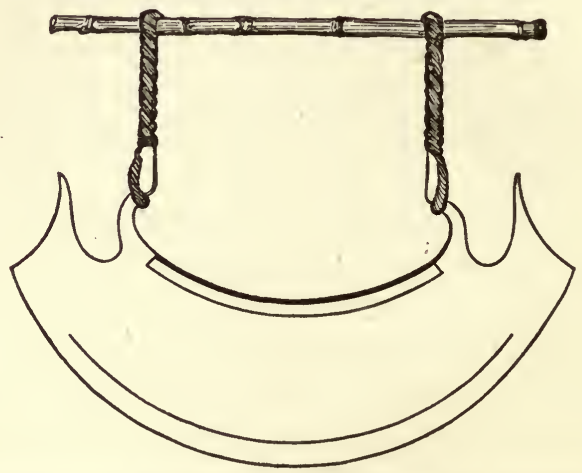

Saw used by natives for cutting segments of the shell.

variety is held sacred by the priests, who administer medicine by it. This shell, from its weight and smoothness, is used in Dacca for calendering or glazing cotton, and in Nepal for giving a polished surface to paper.

The principal demand for these shells is for making bangles or armlets and anklets, and the manufacture is still almost confined to Dacca. The shell is cut or sliced into segments of circles, or narrow rings of various sizes, by a rude semicircular saw, the hands and toes being both actively employed in the operation. 
The introduction of circular saws has been attempted by some European gentlemen, but sturdily resisted by the natives despite their obvious advantages. Some of these bangles, worn by the Hindoo women, are beautifully painted, gilded, and ornamented with gems. The shell rings are coated inside with plaster to smooth the roughness.

Filagree-bordered edges of plaster are also added; patterns and devices of red, blue, and gold are figured on them, and they are further ornamented with silver or gold tinsel, spangles, small coloured glass beads, etc. The larger bracelets, formed of many segments, are made to open to

FIG. 2 I.

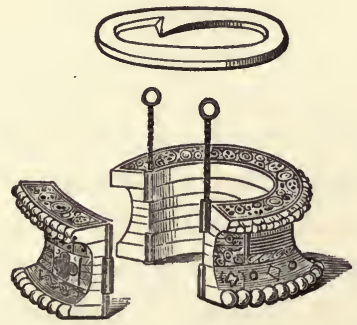

Segment of shell, and bangle or ornamented bracelet of united segments.

admit the hand, by two spiral pins; which unscrew and let out the piece. These bangles are not removed at death, and hence there is a continual demand for them, many wearing several, both on the legs and arms.

These sankka, ${ }^{*}$ or shell bracelets, are extensively made for the women of the hills round Sylhet at Dacca, which has long been celebrated for the manufacture of such bracelets. Four of these shell rings are worn on each wrist. The shakhás, or shell workers at Dacca, distinguish the several

* The native word is variously written-Sungoo or Sankka, Tamil; Shentoo or Sinkham, Telugu. 


\section{The Commercial Products of the Sea.}

shells and their various qualities by the names Titkuri, Pati, Lalpati, Alabela, Dhala, Kulai, and Shurti; the Titkuri being the best in quality of grain, lustre, and suitability for fine cutting and delicate finish.

There is considerable variety in the patterns of these sankka bracelets, from the rude broad, flat ring to the thin, delicate armlet, rounded, or with notched or beaded edges, carved with tigers' heads, enriched with ornamental incising, and illuminated by touches of tinsel, lac-colour, gildings, etc.

A large series of these bangles was sent to the India collection of the London International Exhibition of 1872 , accompanied by specimens of the shells both before and during the process of manufacture, together with the tools used, and photographs showing the men at work. These are now arranged in the India Museum, South Kensington.

The chank fishery was at one time a Government monopoly in India, like the pearl fishery, and produced in the early part of the century a revenue of about $£ 7000$; but as the divers from the coast could easily collect the shells, and as they were also procured by digging for them in the sand in the Jaffna district of Ceylon, the restriction was removed.

A heavy porcelaneous shell, one of the largest known, the Tridacna gigas of conchologists, is much used for benitiers, or receptacles for holy water, in Roman Catholic churches, and for fountain-basins in gardens. It is the largest and heaviest shell known, for the pair of valves have been found in some instances to weigh $500 \mathrm{lbs}$. In its full size it has a byssus like a cable, by which it anchors itself; and this has to be separated with an axe. The valves, when smaller, are sometimes mounted as salt-cellars, candlestickholders, and pin-cushions. Cameos have also been carved on them, but their dead white hue wants the relief of 


\section{Industrial and Manufacturing Uses of Shells. 293}

colour. The hill Dyaks of Borneo wear broad armlets made of this shell, which, when polished by length of use, resemble ivory, but never acquire its yellow tinge. Two of these valued shell-bracelets on each arm are the favourite number with the women.

In the "Voyage of the Rattlesnake" we are told the natives of Coral Haven wear bracelets of solid shell formed by grinding down the Trochus Niloticus, so as to obtain a well-polished transverse section, and another in two or three pieces tied together, making a round smooth ring ; of the former of these five or six are sometimes worn on one arm.

The Queen Conch.-The Strombus gigas, or fountain-shell of the West Indies, fills up the earlier whorls with solid matter, and sometimes weighs five pounds. It is a favourite ornament in milk-shops in consequence of the delicate pink colour of the mouth. It is also ground to powder wholesale for the manufacture of the finer kinds of porcelain, 300,000 having been imported into Liverpool in one year from the Bahama Islands, and used chiefly for this purpose. One vessel, the Crusader, brought home 5000 of these shells from Nassau, New Providence, in the close of 1875 .

The nacreous and iridescent shells used for inlaying and ornamental purposes will be spoken of in the section on mother-of-pearl, but these may claim a few words here. The "green snail" of the dealers, the Turbo olearius, is very largely used for ornamental purposes. Slices of this shell, ground down to a thin surface, are employed for covering or inlaying various articles, such as small stamp-cases, little tablet-covers, fancy boxes, baskets with metallic handles; buttons, earrings, and other articles are made of it, and very pretty ornamental stands, which 


\section{The Commercial Products of the Sea.}

open with a spring, enclosing scent-bottles or cigar-holders, and such like. Fashion has brought into use, of late years, handsome sections obtained from this shell, which have been largely used for ornamenting ladies' hats, for buckles for shoes, sashes, and waist-belts. The light-greenish iridescent play of colour of this shell is more ornamental than that of the true mother-of-pearl. Fine large shells of this species formed the drinking goblets of the Scandinavian monarchs, and are often still met with, very elegantly mounted and set with jewels.

Another shell of this genus, the Turk's cap (Turbo sarmaticus), from the west coast of Africa, is used for making small articles, such as caskets, scent-bottles, brooches, etc.

The ear shells of different species, principally the green kind, Haliotis iris, the common British, Haliotis tuberculata, and some Japan and Californian species, are much used, from their brilliant play of colour, ground down for inlaying papier-mâché work, as well as for making buttons, studs, links, buckles, and earrings. Among other handsome species of ear shell, which are polished for mere ornament or trade use, are $H$. rufescens, $H$. splendens, and $H$. cracherodii.

Sections of white cones, sufficiently large to go on the arm as a bracelet, are so much in request in the Pacific Islands, that dealers in Europe obtain high prices for them. Very often rare fluviatile and terrestrial shells are obtained from native necklaces. One of these necklaces was stolen from an aboriginal dressed figure at the Crystal Palace, the shells being worth to collectors several pounds.

In full dress many of the Pacific Islanders are decked out with large white Ovulum shells, appended to the waist, elbows, and ankles. Necklaces of Natica shells are also 


\section{Industrial and Manufacturing Uses of Shells. - 295}

common in the South Sea Islands. Those made from the Elenchus irisodonta shell were always held in high estimation among the aboriginal women of Van Diemen's Land, worn as ornaments round the neck and head. Necklaces of these are equally esteemed now by English ladies for their beauty and rarity.

The bright nacreous play of iridescent colours, which doubtless first recommended them to notice, were brought out by partial decomposition and removal of the cuticle from long exposure, after being cast on the shore in a dead state. The natives effected the same end artificially and systematically, by placing them in a thick, dense smoke from green vegetable matter. Instead of employing pyroligneous acid thus accidentally obtained, they afterwards came to use vinegar and friction to remove the epidermis, and then rubbed them with various fatty substances until a brilliant polish was acquired. They also boiled the shells with tea and other astringent substances, to deepen the blue-and-green tints characteristic of the shells. They made small holes in the shells, by placing them between their eye-teeth and giving them a nip, and then strung them upon kangaroo sinews. But the last of the aboriginal Tasmanians has passed away, and no more shell necklets thus prepared can be obtained of them.

In New Britain, San Christoval, and other islands eastward of New Guinea, the fierce inhabitants adorn themselves with necklaces of two very beautiful kinds of land shells, both being white, the one having a golden yellow, and the other a vermilion lip. Throughout the islands inhabited by the crisp-haired Papuan race, a large species of Ovulum of a very pure white colour, resembling porcelain, is employed with great effect by the natives in decorating their houses, temples, and canoes. One of the most 
296 The Commercial Products of the Sea.

striking and really elegant ornaments manufactured out of shells by a half-civilized race, is a fillet formed of the nuclei or inner whorl of the pearly nautilus, and worn on the head by the Navigator's Islanders when going to war (4, Fig. 22). Each nucleus is about an inch in diameter, the external coat being removed, so as to exhibit an appearance of the most highly burnished silver. The shells are fastened on a mid-rib of cocoa-nut leaf, supported and tied round the

FIG. 22.
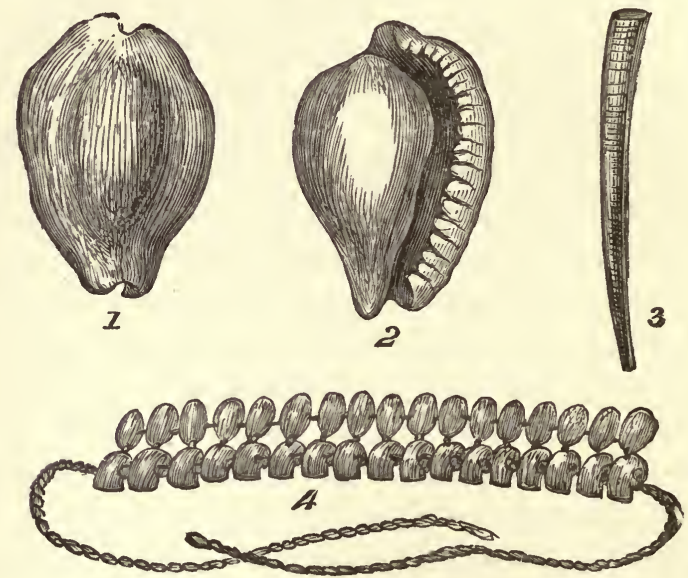

I. Money cowry; 2. Ovulum angulosum (sandal-wood shell); 3. Dentalium (money of West Coast Indians); 4. Fillet of nautilus shells (from Samoa).

head by a cord of sinnet. The pearly nautili are not found at the Navigator's Islands, but are carried thither by European traders from New Caledonia and Fiji, where they are sold to the natives at the rate of about I $s$. each. Occasionally many tons of these shells are brought into the Sydney market for reshipment to Samoa. The species chiefly employed in this trade is the Nautilus macrocephalus. 
Utilization of Shells for Economic and Decorative Purposes.-The next subdivision-the use of shells for spoons, drinking-vessels, lamps, handles for knives, and other purposes of domestic economy or ordinary utility-takes in a very wide range.

The valves of the Anodonta escula are used as skimmers in Brazil, and the shells of the Ampullaria serve to dip up the caoutchouc gum. The Africans on the west coast make much use of the large shells of the Achatina snail, shaped into spoons.

Shells are still much used for scoops, spoons, etc. In many countries the great melon-shell and others are employed to bale out boats; to hold oil and a wick, suspended as lamps ; to skim milk ; and, from some unexplained custom, shells seem a necessary ornament or appendage in the window of the milk-shop or dairy in the metropolis.

The less-civilized inhabitant of coasts frequently forms his knife, his hunting-spear, and his fish-hook of hard shell. In the latter instance it serves the secondary purpose of a glittering bait. The Chinese grind shells to powder, and use this powder in the way we do flock on paper-hangings.

A small white bivalve shell (called Irego by the natives of Western Australia) is used for sharpening their spears when they cannot procure glass.

The Friendly Islander wears the scarce orange cowry as a mark of chieftainship. The New Zealander polishes the Elenchus into an ear ornament more brilliant than the "pearl ear-drop" of classical or modern times, and, with the rainbow-lined, pearly interior of the Haliotis iris, ornaments the eyes of his grotesque images, and inlays the rich carving of his war canoes; and he also manufactures gleaming fish-hooks of the same material. In the Solomon 


\section{The Commercial Products of the Sea.}

Islands the same style of ornamentation prevails ; but there they use the pearly coating of the chambered nautilus, and the nacre of the pearl oyster. Even the wandering savage of the north-east coast of Australia delights in beautifying himself with a spoon-shaped ornament filed from the pearly nautilus. One of the most beautiful substances in nature is the shell-opal, formed of the remains of the ammonite.

In Caldera, Chili, a kind of scallop shell, very finely marked with a delicate pink, is frequently used by the refined portion of the population, as a little dish to hold soap on the toilet-table.

Scallop shells (Pecten) were formerly worn by pilgrims, on their hat or the cape of their coat, as a mark of their having crossed the sea for the purpose of paying their devotions at the holy shrine in Palestine; in commemoration of which they are still preserved in the armorial bearings of many families of distinction, whose ancestors had performed that ceremony. From its use by cooks now, this shell has given the name to "scalloped" oysters. In early times, when plates and drinking-vessels were not so plentiful as they are now, the concave or hollow valve of the scallop served as a cup, and the flat valve for a plate. The idea has even been carried out by our pottery manufacturers, and plates and dishes have been moulded after the forms of bivalve shells. Reticules, needle-books, pincushions, and other articles are made by shell dealers with the scallop shell.

The Mytilus, or mussel shell, has a few applications. When polished, they are made into pretty needle-books and scent-bottle holders, earrings, crosses, pins, and pincushions. They are mounted on marble as paper weights, and are used as a receptacle for gold and silver paint for 
Industrial and Manufacturing Uses of Shells. 299

artists. The Maories of New Zealand employ mussel shells as tweezers to eradicate the hair from their face.

Some of the cockle shells are made into pretty little pincushions, and the shell-flower makers use them to form the hop and other imitations. Common cheap pin-cushions are made with the whelk and many other shells.

Large quantities of small shells enter into trade use, for making shell flowers and different articles of grouped shells on boxes, etc. A great proportion of these are British shells, collected freely on the beach in many parts of our coasts, and most are sold by dealers under the name of " grotto shells."

The shells chiefly used for imitation flowers in forming tulips, moss-roses, passion-flowers, anemones, hops, etc., are parts of the valves of barnacles (Lepas anatifera), Dentalium, Oliva oryza, Marginella, Strigella pisiformis, Pholas dactylus and $P$.papyracea, Tellinas, Cardium, and others. It requires only taste in the selection and adaptation of suitable shells or parts of shells to form the petals of the flowers, and colour is applied to the shell where necessary.

Mr. Mayhew, in his "London Labour and the London Poor," tells us that there are about $\mathrm{I}, 000,000$ of the commoner sorts of shells bought by the London street-sellers, at $3 s$. the gross. They are retailed at $\mathrm{I} d$. apiece, or I $2 s$. the gross, when sold separately; a large proportion, as is the case with many articles of taste or curiosity rather than of usefulness, being sold by the London hawker on country rounds. Some of these rounds stretch halfway to Bristol, or to Liverpool.

Many shells are used for trumpets. Large species of the genus Buccinum are employed by Italian herdsmen in directing the movements of their cattle, and a variety of sonorous sounds may thus be readily produced. They are 


\section{The Commercial Products of the Sea.}

also often used in North Wales by the farmers to call their labourers, and in Lithuania and Muscovy by the herdsmen to assemble their cattle. In the West Indies the common fountain-shell, a species of Strombus, is also used to call in the negroes from the sugar-cane fields; the interval of "shell-blow," as it is termed, being the dinner-hour. In the East Indies chank shells are used for the same purpose by the Brahmin priests, and the great Triton (Triton tritonis) is so employed by the Pacific Islanders, who make a hole in the lip and then use it as a speaking-trumpet, The mountain-priests of Japan, according to Kaempfer, wear a kind of Buccinum, a smooth and white shell with beautiful red spots and lines. It hangs down from their girdle and serves them as a trumpet, having for this purpose a tube fastened to the end, through which they blow upon the approach of travellers, to beg their charity. It sounds not unlike a cowherd's horn. Murex colossus is another shell often used as a trumpet.

In the South Kensington Museum there is a powderflask formed of a Murex shell, mounted in silver inlaid with acanthus ornament in niello work, probably of the seventeenth or eighteenth century, and in the India Museum there is a powder-flask made of a Turbo shell, mounted.

Of late among the curious uses to which the Turbo and some other shells have been applied here is for pipebowls. Uncivilized tribes have been before us even in this utilization ; for Adams, in his "Voyage of the Samarang," tells us that among the Bashee group, and more particularly on the island of Ibayat, the natives form very elegant and commodious pipes from different species of shells, the columella and septa of the convolutions being broken down, and a short ebony stem inserted into a hole at the apex of the spire. Pipes of this kind are formed from the Mitra 


\section{Industrial and Manufacturing Uses of Shells. $30 \mathrm{I}$}

papalis, and others out of Mitra episcopalis and species of Cerithium and Terebra.

The beautiful shell of the Nautilus pompilius is often mounted on a stand, with designs engraved on it, and used for holding flowers. The shell of the pearly nautilus is made into a drinking cup by the inhabitants of the East. The outer coating of the shell being first removed, so as to render visible the pearly layer, various devices are often engraved on it.

At the first London International Exhibition, a curious specimen of patient toil was shown by a working man of the name of Wood, in an engraved nautilus shell dedicated to the memory of Nelson, the only instrument he had employed being a small penknife. On the front was represented the globe, with Britannia seated upon a lion, and possessed of the usual emblems of sovereignty, surrounded with a border composed of oak-leaves and acorns most elaborately engraved. Upon each side were a number of lines from Fitzgerald, commemorative of the victories of Nelson, so small, however, that they almost required the aid of a microscope to decipher them; and on one side of the shell was a representation of Peace, seated on the prow of a vessel, pointing to the victories achieved by the hero. On the other was represented St. George and the Dragon. The head of the shell represented that of a parrot. The designs were most artistic, and the execution remarkably fine. The same ingenious artist had a short time before presented to her Majesty a similar shell, on which were designed, with the same rude graver, the royal arms, the Prince of Wales's feathers, the Great Britain and the Great Western steam-ships, with a full description of the same; also several verses from Pope, amounting altogether to about I500 words, which were tastefully en- 


\section{The Commercial Products of the Sea.}

graved in German text, old English, Roman, and italic characters. On the occasion of presenting the shell, a sum of money was put into the hands of the artist ; and a few days after, the poor man was astonished by the receipt of a large packing-case, which, upon opening, he found to contain a proof impression of Sir G. Hayter's "Coronation" picture, framed and tastefully ornamented with the rose, shamrock, and thistle in burnished and dead gold.

The Chinese are very fond of having patterns carved on the nautilus shell, while the body of the shell is uncoated to show the nacre.

The shell of an Anodonta is used for the bridge of musical instruments by the Mittoo tribe in Africa, and round fragments of shell are used by them for gambling purposes. In Japan the ladies play a game with the valves of shells with painted designs on them.

Miscellaneous Products of the Mollusca.-In China the shells of a great number of molluscs, inhabitants of the sea, river, or land, are pulverized and washed with great care to prepare an absorbent powder, employed in eruptions and for toilet use. The valves of some Unios, of Arca granosa, and oyster shells are also calcined and pulverized to prepare medicines prescribed in fevers, apoplexy, and hæmorrhages.

Opercula.-Many species of gasteropods develop an operculum or lid on a particular lobe of the foot. It may be composed either of layers of horn or of dense shelly substance, the principal office of which is to close the mouth of the shell when the animal retires within it. The operculum always exhibits more or less of a spiral development. In some cases the spirals are numerous and nearly concentric ; in others, and these the most common, the new matter is added principally on one side, and the 


\section{Industrial and Manufacturing Uses of Shells. 303}

nucleus is then very eccentric. The spirals are invariably sinistral in dextral shells. Horny operculum-Buccinum undatum; calcareous-Trochus and Triton, Turbo sarmaticus, T. marmoratus, nodosus, Cookii, and torquatus. Some of these coloured solid opercula have recently been polished and set as ornaments of jewellery for necklets and pins, studs and solitaires.

The opercula of the screw or stromb shell, and some other species, were formerly officinal under the name of Unguis odoratus or Blatta byzantina. Small horny opercula, called Sheitam ternah, are still used medicinally on the coast of Syria. The operculum of the whirl-wreath or Turbo cochlus and other species form the umbilicus veneris.

Dyes from Mollusca.-Formerly some valuable dyes were obtained from molluscs, of which sepia and the ancient Tyrian purple dye are examples; but the abundance of mineral, insect, and vegetable dyes now available renders these valueless at present. Still a notice of them is worth attention.

The colour known as sepia among artists is a liquor contained in the ink-bag of Sepia officinalis. It is of a powerful dusky-brown colour, and works admirably in water, being used in making drawings in the manner of bistre and Indian ink, but is not applicable with oil. This warm and sober colour has not, up to the present, been employed in the photographic impressions called "the carbon" process. Sepia is sold in little bladders, which have to be freed from membranes. This is very easily done by boiling it for a moment in chloric acid, which destroys the envelope, and causes it to become detached by trituration with the hands in water. The bag or pocket, being light, floats and is easily separated by filtering. The black substance which remains is dried, after having been washed in hot water. 
304 The Commercial Products of the Sea.

When pulverized fine enough, this colour is used for water-colour drawings; but its hardness makes it necessary to mix with it some foreign colour (sienna or the like), to facilitate the operation of pulverizing.

By the following method this laborious crushing, which is always imperfect, is avoided, and the colour obtained very pure. One hundred and fifty grammes of potash or caustic soda are put into a capsule; it is then placed on the fire, and when the potash is dissolved in the water, I00 grammes of the dry matter are added gently, but keeping it in motion until completely dissolved. It is then taken from the fire, and after a few minutes a little water (the less the better) is added, and so on until complete evaporation. During this process an extremely strong ammoniacal odour is given off, and the dry ink has become soluble in alkali, but it is insoluble in water or in acid.

There is great dispute as to the precise source of the celebrated Tyrian purple dye, so much used for the garments worn by kings and emperors of old. Some authors attribute it to the rock lichens or orchella weed of commerce of the present day, but the general and most probable opinion is that it was obtained from some species of Murex (M. brandaris and trunculus) and Purpura ( $P$. patula and $P$. persica), the animals of which furnish a rich colour. The small shells were bruised in mortars; the animals of the larger ones taken out.

In Britain there are several kinds of mollusca which furnish a dye of this sort. Helix Fanthina, which occurs in the Mediterranean, Atlantic, and South Seas, affords a similar fluid.

If the shell of Purpura lapillus is broken, there is seen on the back of the animal, under the skin, a slender, longitudinal, whitish vein, containing a yellowish liquor. 


\section{Industrial and Mamufacturing Uses of Sheils. 305}

When this juice is applied to linen, by means of a small brush, and exposed to the sun, it becomes green, blue, and purple, and at last settles into a fine unchangeable crimson. Neither acids nor alkalies affect its colour, and it may be conveniently employed in marking linen where an indelible ink is desirable.

Linton, in his work "On Ancient and Modern Colours," states that the Purpurce of the best description were chiefly found on the rocks of Tyre, on the coast of Asia. They were also collected at Mininge on the Grætulan shore in Africa, and on the coast of Laconia in Europe. The colours varied according to the locality in which they were taken. Those from Pontus and Galatia in the north produced a black dye; in the equinoctial, regions a violet hue predominated; whilst in the south, as at Rhodes, the colour was of a richer red. These purple shell-fish were called Pelagia, and they were distinguished by the district, as well as by the food which the locality supplied. Two hundred Buccina were added to II I Pelagia to make the purple colour so much eulogized by Pliny, and one of the three shades of purple recorded by the ancients. To make a purple dye, they also mingled several varieties of shell-fish, adding nitre, urine, water, salt, and fuci. But the dye from the Buccina required only pure water.

Experimental investigations in zoology showed that the tint of the purple varied in accordance with the nature of the haunt in which the shell-fish was found. Thus, when it lived among seaweeds or mud, the juice it contained was comparatively worthless; when amongst pebbles, its quality was much improved; and it produced the richest purple when the food and locality of the fish were of varied materials. Researches carried still further proved that, to produce the richest and most costly dye which art could 


\section{The Commercial Products of the Sea.}

exhibit, the liquid of which we have been speaking must be used in conjunction with that which was procured from shell-fish belonging to other species. Some of the Tyrian garments had a beautiful play of colours, like the shot silks of our own time; and this play of colouring, it is said, was first suggested to them by having observed a similar one upon the neck of a pigeon. With the destruction of the ancient city of Tyre, the beautiful art of dyeing this peculiar colour was lost for centuries, until it was again recovered by the scientific men of our country; and the discovery would probably have been of much value to commerce, had not the use of it been rendered unnecessary by another natural history discovery, viz., the cochineal insect. This has been again to a great degree replaced by the discoveries of chemistry in the coal-tar colours.

The Scalaria clathrus also furnishes a purple liquor of considerable beauty, but it is destructible by acids, and gradually vanishes by the action of light. The Planorbis corneus likewise yields a scarlet dye, but of still less permanency than the Scalaria, as all attempts to fix it have hitherto proved ineffectual.

In the reign of Augustus one pound of wool dyed with Tyrian purple sold for about $£_{3} 6$ sterling. We need not wonder at this enormous price when the tedious nature of the process is considered, and the small quantity of dye obtained from each mollusc. For $50 \mathrm{lbs}$. of wool the ancients used no less than $200 \mathrm{lbs}$. of the liquor of the Murex, and roo pounds of that of the Purpura, being six pounds of liquor to one of wool; consequently the rich Tyrian purple fabrics vied in value even with gold.

Marine Silk.-Among the many novelties which industry obtains from the sea, one of the most curious is the textile product made with the byssus of the Pinnas of the Mediter- 


\section{Industrial and Manufacturing Uses of Shells. 307}

ranean-the fin-shells or sea-wings, as they are termed. The species are the Pinna nobilis, etc.

The shells, which are in general very fragile, resemble in form those of the larger species of mussels, being long FIG. 23.

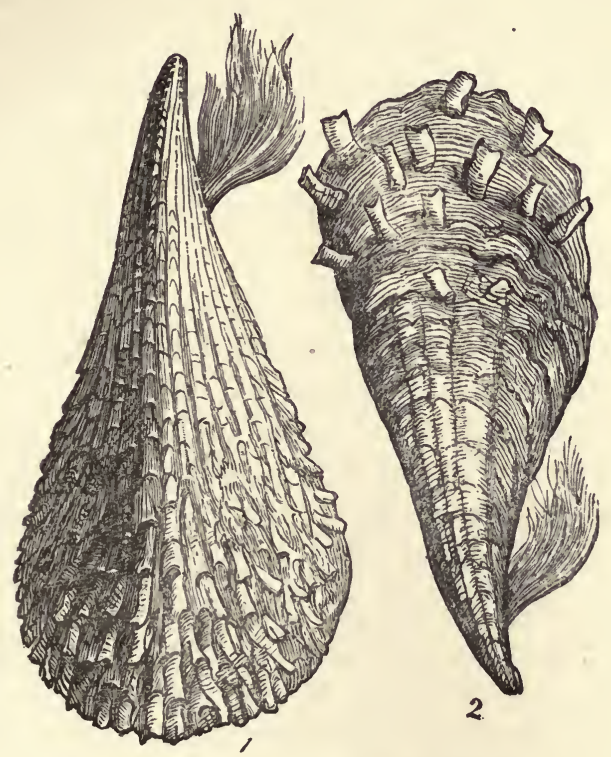

I. Pinna nobilis. 2. Pinna rugosa.

and tapering, narrow at the back, and gradually expanding to a considerable breadth towards the opposite extremity. There are some 20 or more species of the genus, which produce in large quantities a very fine sort of silky byssus or braid. It is called by the fishermen lana pinna, or fishwool. These bivalves are provided with a tuft of delicate fibre, which cannot be better compared than to fine hair or silk, or spun glass; with this they attach themselves to the rocks, living continually under water. 


\section{The Commercial Products of the Sea.}

The ancients made this an article of commerce, greatly sought after, and the robes formed of it, called "tarentine," were very much in esteem. It is said that the scarf of the turban of Archytas was made of this fibre. In the year I754 a pair of stockings, made of it, were presented to Pope Benedict XV., which, from their extreme fineness, were enclosed in a small box about the size of one for holding snuff. A robe of this material is mentioned by Procopius as the gift of a Roman emperor to the satrap of Armenia.

Even in the present day the fibre is utilized, but more for its rarity than anything else. The women comb the lana with very delicate cards, spin it, and make from it articles which are much esteemed for the suppleness of the fibre, and their brilliant, burning gold lustre.

A considerable manufactory is established at Palermo; the fabrics made are extremely elegant, and vie in appearance with the finest silk. The best products of this material are, however, said to be made in the Orphan Hospital of St. Philomel, at Lucca.

At the London Exhibition of I862, V. Dessi Magnetti, of Cagliari, showed byssus of the Pinna, thread, cravat, and gloves made of it, and Mariano Randaccini a shawl made with it. At the Paris International Exhibition, in 1867, Paul Montego, of Asti, Alessandria; also showed shawls made of this byssus.

A considerable number of bivalves possess what is called a byssus, that is, a bundle of more or less delicate filaments, issuing from the base of the foot, and by means of which the animal fixes itself to foreign bodies. It employs the foot to guide the filaments to the proper place and to glue them there, and it can reproduce them when they have been cut away. Reaumur believed them 


\section{Industrial and Manufacturing Uses of Shells. 309}

to be spun from a secretion in the foot. Poli thinks them to be merely prolongations of tendonous fibre.

The Pinna possesses a machine as incontestibly mechanical as a wire-drawer's mill. It is provided with an external member like a finger, and this contains a glue, which the animal exudes at pleasure by means of a variety of minute perforations in the lip. This glue or gum, as in the instance of the common spider or the silkworm, having passed through these apertures, becomes threads of almost imperceptible fineness; and these, when combined, compose the marine silk which is so much admired by the Sicilians.

The animal first attaches the extremity of the thread, by means of its adhesive quality, to some crag or pebble of unusual size; and when this is effected, the Pinna, receding from that point, draws out the thread through the perforation of the extensile member by a process which Paley, in describing the similar operations of the terrestrial silkworm, justly compares to the drawing of wire. One difference alone exists: the wire is the metál unaltered, except in figure; whereas, in the forming of the thread, the nature of the substance is somewhat changed, as well as the form ; for, as it exists within the water, it is merely a soft and clammy glue, the thread acquiring, most probably, its firmness and tenacity from the action of the air upon its surface at the moment of exposure.

This byssus forms an important article of commerce among the Sicilians, for which purpose considerable numbers of Pinna are annually fished up in the Mediterranean from the depth of 20 to 30 feet. An instrument called a "cramp" is used for the purpose. It is a kind of iron fork, with perpendicular prongs eight feet in length, each of them about six inches apart, the length of the handle being in pro- 


\section{Io The Commercial Products of the Sea.}

portion to the depth of the water; for, notwithstanding the extreme delicacy of the individual threads, they form such a compact tuft that considerable strength is necessary in separating the shells from the rocks to which they are attached. The tuft of silk is broken off and sold to the country women, who wash it in soap and water. They then dry it in the shade, straighten it with a large comb, cut off the useless root part by which it adhered to the animal, and card the remainder. By these means a pound of coarse filaments is reduced to about three ounces of fine useful thread. This is fabricated into various articles for the person, such as shawls, stockings, caps, waistcoats, gloves, purses, etc. The web is of a beautiful yellow brown, resembling the burnished gold hue which adorns the backs of some splendid flies and beetles.

A very large mollusc, the giant clam (Tridacna gigas), found in the seas of the Eastern Archipelago, has a byssus formed of many tough threads, but slightly elastic, spun by the animal, or rather cast in a mould, thread by thread; a gelatinous fluid being secreted in a long groove or canal, formed by the foot, which in the air rapidly acquires solidity. When complete, the united threads form a strong cable, adhering by the other extremity to the rock so firmly as to resist the agitation of the sea, and so tough as to be severed only by an axe. Marsden mentions one of these shells which was more than $3 \mathrm{ft}$. $3 \mathrm{in}$. long, and $2 \mathrm{ft}$. I in. wide; and specimens have been seen which had attained the enormous length of four feet. 


\section{$($ 3I I )}

\section{CHAPTER XII.}

\section{SEAWEED AND ITS USES.}

Various uses of Seaweed-Seawrack for packing and upholstery-For manure -Kelp and iodine-Carrageen moss-Seaweed for food-Large employment in China and Japan-Gelose-Other applications of seaweed.

SEAwEeds are largely employed in Europe and the extreme East in industry, agriculture, and manufactures.

The marine plants are of much more importance than is generally supposed, and it is doubtful whether they may not yet be further utilized to advantage. Liebig, in his "Familiar Letters on Chemistry," says, "Every one knows that in the immense, yet limited, expanse of the ocean, whole worlds of plants and animals are mutually dependent upon, and successive to, each other. The animals obtain their constituent elements from the plants, and restore them to the water in their original form, when they again serve as nourishment to a new generation of plants. The oxygen which marine animals withdraw in their respiration from the air, dissolved in sea water, is returned to the water by the vital process of sea plants ; that air is richer in oxygen than atmospheric air, containing 32 to 33 per cent., while the latter only contains $2 \mathrm{I}$ per cent. The oxygen now combines with the products of the putrefaction of dead animal bodies, changes their carbon into carbonic acid, their hydrogen into water, while their nitrogen assumes 


\section{I2 The Commercial Products of the Sea.}

again the form of ammonia. Thus we observe that in the ocean a circulation takes place without the addition or subtraction of any element, unlimited in duration although limited in extent, inasmuch as, in a confined space, the nourishment of plants exists in a limited quantity."

We well know that the marine plants cannot derive a supply of humus for nourishment through their roots. Look at the great sea-tangle, the Fucus giganteus. This plant, according to Cook, reaches a height of 360 feet, and a single specimen, with its immense ramifications, nourishes thousands of marine animals; yet its root is a small body, no larger than the fist. What nourishment can this draw from a naked rock, upon the surface of which there is no perceptible change? It is quite obvious that these plants require only a hold-a fastening, to prevent a change of place-as a counterpoise to their specific gravity, which is less than that of the medium in which they float. That medium provides the necessary nourishment, and presents it to the surface of every part of the plant. Sea water contains not only carbonic acid and ammonia, but the alkaline and earthy phosphates and carbonates required by these plants for their growth, and which we always find as constant constituents of their ashes.

Seaweeds or fuci are used directly as manure, for the manufacture of soda, iodine, bromine, and some like Irish moss, etc., for the manufacture of gelose. Dried and pressed seaweeds are also used for ornamental or botanical purposes. In Scotland and other northern countries seaweed is used in winter for feeding horses, cattle, and sheep, and is eaten by deer when other food is scarce.

The beneficial effects in scrofulous swellings and goitre of the vegetable ethrops and of the sponge charcoal, which had been introduced by Armand de Villeneuve near 
the close of the thirteenth century, and the discovery of iodine in the ashes of sea plants, induced Dr. Coindet, of Geneva, in I8I9 to study the effects of iodine, and led to the introduction of that element into medicine.

The Fucus vesiculosus, Lin., grows on rocky shores of the Atlantic on or near high-water mark. Formerly it was known by the name of Quercus marina or sea-oak, its common English names being bladder-wrack, sea-wrack, sea-ware, kelp-ware, and black tang. Of late the bladderwrack seems to have been employed to some extent medicinally in the United States. It has also been employed in France in the form of extract, by exhausting the plant with 54 per cent. of alcohol.

There are two species in which a considerable trade is carried on-a lichen, and the sea-wrack or Zostera marina, vulgarly known there under the name of "pailleule," which have become considerable sources of profit to the inhabitants. The moss or lichen is used by chemists and for making gummy preparations, and is even forwarded to Belgium. The Zostera marina is largely used for stuffing beds and chairs by packers and upholsterers, under the name of crin vegetal-in England, "alva." In I 873 over 4, I00,000 lbs. of this dried weed were sent from Granville by land and sea. As this quantity represents about two-thirds of the whole sale, the total may be approximatively estimated at about $£ 2,000$ in value. The Zostera has the habit of the seaweeds, although belonging to another natural order.

Algæ and fuci are the scientific names given to various marine plants which grow at the bottom of the sea. They are collected on the coasts in different parts of the world, where they are found at certain periods of the year, driven by the currents and thrown on the beach by the waves and tides. 


\section{The Commercial Products of the Sea.}

Many persons may think it strange that we should occupy ourselves with plants which flourish in the sea, when we possess so many useful plants on the land. To this it may be replied that very little is known of the considerable commerce which is carried on in various parts of the world, more especially in the far East. Hence we propose to publish, for general information, some reliable details bearing upon this subject.*

In France, on the coasts of Normandy and Brittanyat Noirmontier for instance-large quantities of seaweed are collected. It is generally the species known to naturalists under the name of Fucus cornosus. There large numbers live entirely on the result of the harvest of seaweed they collect each year. The seaweeds are largely employed for industrial purposes. Upholsterers and others use them for stuffing couches, stools, etc., in which they too frequently are substituted for horsehair. They are used to stuff mattresses, especially beds for children, because their aromatic odour keeps away insects. Packers use seaweed for wrapping fragile objects. Chemists obtain from them a number of valuable products, such as saline matters or soda, chlorides, sulphates, silicates, iodine, bromine, etc.

At the last Maritime Exhibition held in Paris, seaweeds were shown dyed various tints after decólouration. This new application was to replace paper cuttings, the price of which, owing to numerous uses, had much advanced. The seaweeds, after drying, are pressed into bales of about Ioo kilogrammes. The colour is brown, something like dried tobacco.

Employment of Seaweed for Manure.-The Chinese and

* We quote from an interesting article on the uses of seaweed, published in the "Bulletin de la Société d'Acclimatation of Paris" for March, 1878, by M. E. Renard. 
Japanese from time immemorial have recognized the value of seaweeds in agriculture; but as the population of those countries became more numerous, and the adoption of the algæ as a healthy food became better known, they attained a higher value, and their employment as a fertilizer was to a great extent replaced by other substances, especially the excreta of towns. In Japan seaweed is often carried to the slopes of mountains to form humus to nourish trees.

The services rendered to agriculture by seaweeds are well known and very important. Buried in the earth, they are converted by fermentation into an excellent humus, of great service to plants, and the cultivators on the coasts of many countries carry away thousands of cartloads.

At Granville, in France, there is a large commerce in seaweed. The value of that used for manure cannot well be determined.

In France the collection of seaweed is only allowed at certain fixed periods, while in China and Japan it is carried on daily. Still, the former plan may have its advantages, as it is known that it is in the midst of this exuberant vegetation of marine plants many species of shell-fish, such as mussels, scallops, etc., live. It is also the spawning ground of a certain number of fish; and, finally, here the young fry and the crustacea find a shelter from the voracity of the large species of fish with sharp teeth, such as the congers, bonitos, etc.

The seaweeds form in the Atlantic considerable banks, especially in the part known as the Gulf Stream. There ships pass through large spaces entirely covered with them. Sometimes the banks take the form of long serpents, the two extremities of which cannot be seen. To these accumulations of plants the sailors give the name of Neptune's 


\section{The Commercial Products of the Sea.}

gardens; and the bunches of vesicular grains which support these plants at the surface of the water, they name tropical grapes. Up to the present time these seaweeds have remained unutilized, doubtless because of the cost of transport.

Some of the species of seaweed are richer in ash than others. The most generally diffused species, the Fucus vesiculosus, or bladder-wrack, seems to withdraw the largest amount of saline and earthy matters from the sea water. Pereira, in analyzing the ash, found in it nearly 20 per cent. of common salt, and II to I 2 per cent. each of potash, soda, and lime, and $24 \frac{1}{2}$ per cent. of sulphuric acid.

FIG. 24.

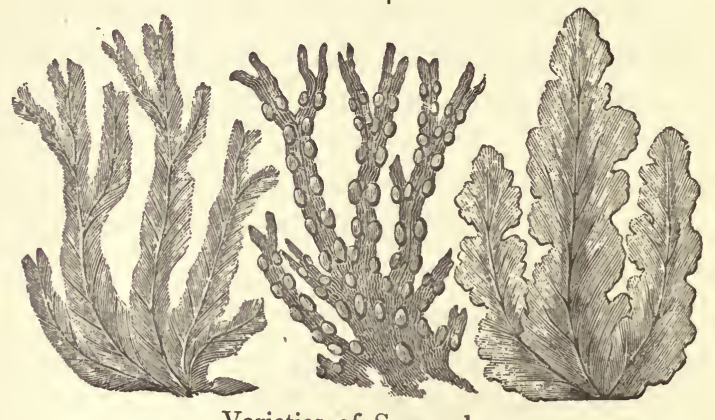

Varieties of Seaweed.

Fresh weed usually yields 16 per cent. of ash, or 320 pounds to the ton of weed; and each ton of ash would yield I $8 \mathrm{lbs}$. of phosphates, iron and lime, $38 \mathrm{lbs}$. of potash, and other mineral substances, making up a total of 164 lbs. of valuable saline matter, or more than one-half of the whole ash.

Valuable as are many of these ingredients to plants, the application of seaweed as a manure has some remarkable properties which do not appear to be explained by analysis. 
The weeds are largely used in the west of Ireland, and a price paid for them far beyond their value as indicated by chemical composition. As a manure for potatoes they are hardly excelled. Along the coast of Cornwall they are successfully used for grass, cereals, and roots, and for apple orchards, spread round each tree. The broccoli, which is cultivated round Penzance in hundreds of acres, knows no other manure. From Io to 20 tons per acre is the usual quantity applied. They act very rapidly, softening and decomposing in the soil so quickly that their effects are confined altogether to the special crop to which they are applied.

On the French coasts on the littoral of the Channel the collection of seaweed is carried on on an extensive scale. It was officially estimated some years ago at more than $2,000,000$ cubic yards annually, or in weight about $2,250,000$ tons. It is collected in various ways, with a drag, by the spade, by a rake with long handle, etc., and loaded into barges, carts, on donkeys, etc. So important is seaweed there considered as a fertilizer, that a work was published specially devoted to the subject.*

The collection of seaweed, by cutting from the roots, forms a considerable source of employment for the poorer classes on the coasts of Brittany. It is only permitted to be carried on from the period of full moon in March to the full moon of April. The collection of the driftweed thrown on the shores is, however, prosecuted all the year round.

In the Channel Islands the harvesting of the cut weed is carried on at fixed times-at Guernsey from July i7th to August 3Ist, and at Jersey for Io days from March Ioth and June 20th. About 30,000 loads are collected annually at each of the islands.

* "Études sur les Engrais de Mer," par J. Isidore Pierre. Paris: A. Goin. 


\section{The Commercial Products of the Sea.}

Marine plants afford a large revenue for the manufacture of kelp and iodine. Kelp is prepared by burning the dead weeds till they are reduced to hard, dark-coloured cakes, in which state it is sent to market. Kelp is the only commercial source for the production of iodine, and its immense value in photography and in medicine has given an impulse to the manufacture of kelp, which renders it by far the most important of all the applications of seaweed. The average yield of iodine in Scotland from a ton of driftweed kelp is about five pounds.

The proportion of iodine in sea water appears to be very small, and it would require more than $30,000,000$ pounds of sea water to furnish the marine algæ with one pound of iodine.

The production of kelp in the United Kingdom amounts to about 10,000 or I I,000 tons; the manufacture is carried on in Ireland, the Western Islands, and Orkney and Shetland. In France there are many large factories at Granville, Cherbourg, etc.

The manufacture of iodine is chiefly confined to Great Britain and France, for very little is produced in any other countries. It was attempted on the American coasts of the Atlantic, but the weed was found to be of too poor a quality. The average production of iodine is about io lbs. to the ton of kelp, and as it requires 20 tons of wet weed to produce one ton of kelp, the total quantity made represents the burning of 400,000 tons of seaweed annually. At the present price the iodine produced is of more value than the alkaline salts, which were the original object of the industry.

Carrageen Moss.-One of the best known of the algæ in commerce is the Chondrus crispus, the source of carrageen or Irish moss, which is sometimes employed as a substi- 
tute for size and in brewing. It possesses nutritive, emollient, and demulcent properties, and may be employed in the form of a decoction or jelly in pulmonary complaints and other cases. Bandoline or fixature, for stiffening the hair and other purposes, is commonly prepared from carrageen. The market supply for England is obtained from Clare and the west coast of Ireland. It used to be sent to the United States, where it is kept on sale by

FIG. 25.

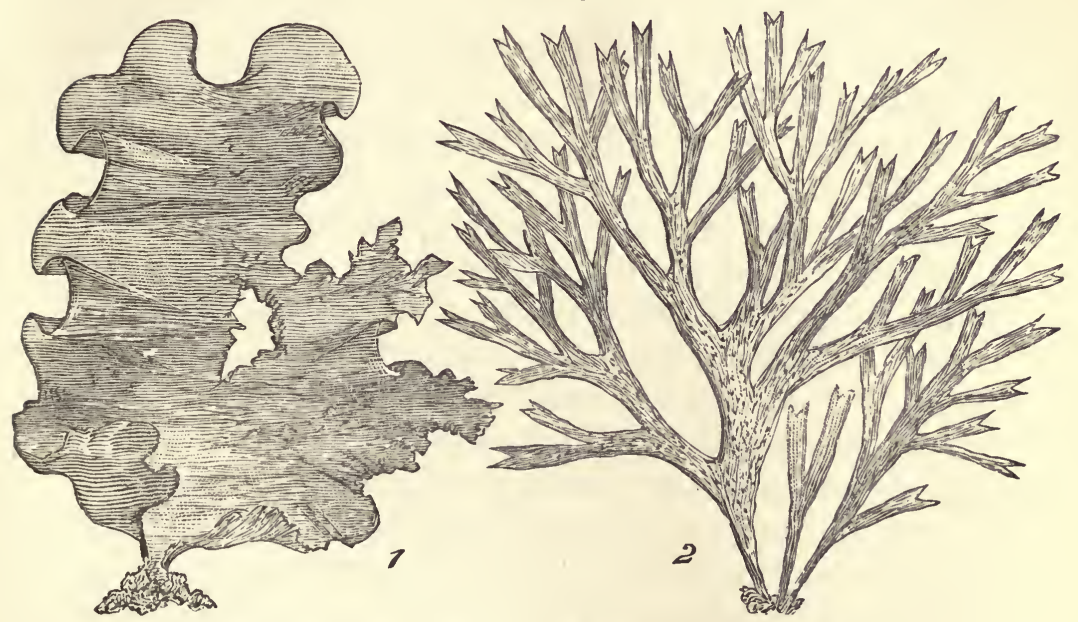

1. Ulva latissima (green sloke). 2. Chondrus crispus (carrageen moss).

most druggists. But it was soon found growing in immeasurable abundance along the whole Atlantic coast, from Nova Scotia to Long Island.

Comparatively few are aware of its wide and varied use in the arts, or of the thousands of barrels of it employed annually by manufacturers of paper, cloth, felt and straw hats, etc., and by brewers. Carrageen is to be found more or less abundantly all along the North Atlantic 


\section{The Commercial Products of the Sea.}

coast, ranging between low-water line and the depth of 40 feet or so ; but as a rule its fronds, which correspond to the leaves of air plants, are so numerously inhabited by small mollusca that they are spoiled for other use. The clean-growing article seems to be limited almost wholly to certain ledges in the neighbourhood of Scituate, Massachusetts. Here, where the waves of the Atlantic dash with full force upon the rocky coast, the carrageen grows to perfection; and, wherever it escapes the spawn of mussels and other shell-fish, is gathered during the summer season in vast quantities. The harvest begins in May and ends about the Ist of September.

The gathering is made in two ways-by hand-picking during exceptionally low tides, and by means of longhandled iron-toothed rakes at ordinary tides. Of course the work cannot be carried on except in fair weather. Hand-pulling is possible only during the bi-monthly periods of spring tides, that is, when the moon is full and again at new moon. At such times high tides occur about midday and midnight, and the ledges are exposed for moss gathering morning and evening. The mossers' boats are rowed to the rocks where the finest grades abound, and the gatherers select with care the growths that are freest from minute shells and other foreign matter. This portion of the crop, if properly handled afterwards, generally goes to the apothecary, and fetches a price two or three times that of the common grade. As the tide rises the pickers are driven to their boats, and proceed to the outer mossbearing rocks, where the rake is used, as it also is during ordinary low tides. Moss taken in this way is not so clean as the hand-picked, and is always mixed with tape grass, which must be removed during the process of curing and packing. 
The preparation is the most critical part of this peculiar farming. On being brought to the shore the moss is black and unsightly; it must be bleached as well as dried. The bleaching is effected by repeated wetting and drying in the sun; and, as the moss is readily soluble in fresh water, the bleaching beds are situated near the banks of the salt creeks that abound along the shore. After drying, the moss is packed in tubs and rolled to the water, where it is thoroughly washed, then rolled back to the bleaching bed, to be dried again in the sun. Five or six such exposures are usually sufficient. On the bleaching ground the moss is carefully spread and turned, and watchfully guarded against wetting by rain. In this process it changes from black to red, then to the yellowish-white of the perfected article. When properly cured the moss is stored in bulk, in shanties, where, as time permits, it is picked over and packed in barrels. The crop averages about 500,000 lbs. a year; and, owing to the brighter and more abundant sunshine of the American coast, the moss has a better colour and is of finer quality than the Irish product.

The principal useful seaweeds occurring on the United States coast are the following :-

For Food.-Chondrus crispus, Lyngb., commonly called Irish moss. It is abundant on the New England coast, particularly to the north of Cape Cod, growing just below water mark. It is gathered in large quantities at Hingham, Massachusetts, and sold for making blancmange, puddings, and sea-moss farina. It is also used by brewers for clarifying, and by calico-printers.

Scherzymenia edulis, Grev. Common dulse, sold roughdried in the seaport towns of the Northern States ; principally eaten by sailors and children. That found in the American markets is generally imported from the British 


\section{The Commercial Products of the Sea.}

Provinces, although the plant is very common in New England.

Porphyra vulgaris, Ag. Laver; eaten stewed in some parts of Europe. It is imported from China by the Chinese living in the United States, and even by those as far east as Massachusetts, although the plant is common on the Massachusetts shore.

Alaria esculenta, Grev. Common on the New England coast north of Cape Cod. It is eaten in Scotland, but not in the United States. No doubt, Euchemia spiniforme of Key West, Gigartina mammilosa (often gathered by mistake for the true Irish moss), the Californian species of Chondrus, and some of the species of Gracilaria are quite as good for culinary purposes as the Irish moss.

Other Uses.-The sea-lettuce (Ulva latissima, L.) is used by owners of aquaria for feeding some of the marine animals, particularly mollusca.

Many of the seaweeds are used as fertilizers. The larger dark-coloured seaweeds are roughly distinguished by the inhabitants of the shore as rock-weeds, or those furnished with small bladders or snappers, and kelp. The rock-weed of New England is composed almost entirely of three species of Fucus-F. vesiculosus, $F$. nodosus, and $F$. furcatus. The kelp of New England is composed of the devil's aprons, species of Laminaria, the sea-colander, Agarum turneri, and Alaria esculenta. The rock-weeds and kelp are all useful for manure, and are either scattered over the land and allowed to rot, or else manufactured, together with other substances, into marketable fertilizers.

The red seaweed (Polysiphonia Harveyi) is said at times to be washed ashore in Peconic Bay in such quantities that it is used as manure.

The great kelp of California (Macrocystus pyrifera) 
forms entangled masses, which serve as natural breakwaters on the exposed portion of the Californian coast. The leaf-blades of the same plant are used by sailors in high southern latitudes for rolling up into cigarettes.

The very long slender stems of Nercocystis Lutkeana, the great bladder-weed of the west coast, are used as fishing lines by the Indians of the north-west ; and lines made of Chorda filum are employed similarly in Scotland. The rough-dried stems of Laminaria saccharina, L. longifolius, L. flexicaulis, and other large species of Laminaria, under the name of "artificial staghorn," are used for making handles to knives, paper-cutters, and other ornamental purposes. At one time an attempt was made to establish a manufactory of buttons out of dried Laminaria stems, at Marblehead; but the attempt was given up, as the buttons did not bear washing. The dry stems of the Laminaria, particularly the digitate species, as L. flexicaulis, are used by surgical instrument makers in the manufacture of sponge-tents.

Corallina officinalis, L., was formerly used in medicine as a tonic.*

In Ceylon a common seaweed (Spharococcus lichenoides, Agardt) is much used as food, and so is another species (Euchemia speciosa) in Western Australia.

The Chinese import large quantities of dry seaweed from Japan, which they use in cookery in place of salt, and also as a vegetable to thicken soups. It is collected on all the coasts of Jesso, and in the inland sea of the environs of Nagasaki and Sinonosaka. It is an important article of export at Nagasaki and Hakodate, the price being from two and a half to four dollars the picul, or Ios. to $16 s$. for one and a half cwt.

* Baird's Report on Fisheries. 


\section{The Commercial Products of the Sea.}

The Chinese "Herbal" mentions various species of seaweed as possessing strong and well-known therapeutic properties, and of special value in the dispersion of hard tumours,-goitre, for example. They have long been acquainted with the general virtues of the various species of Laminaria, and these varieties are mentioned as occurring along the coasts of the Eastern Sea, the coast of Corea, and the Malayan Archipelago. The great "Herbal" speaks of seven chief species. The people in the maritime provinces of China eat seaweed plentifully, both medicinally and as a vegetable food, besides using it as a manure; in this custom resembling the inhabitants of our own Hebrides. It is prescribed alone, chiefly in the form of tincture, its saltish taste having been first washed away, or it is mixed up with other medicines in various prescriptions. The uses to which the different kinds of seaweed are put correspond with our own before the discovery of iodine.

In the midst of the large islands of Java, Sumatra, Borneo, etc., and the thousands of islets known under the geographical denomination of the Indian Archipelago, the seaweeds, favoured in their growth by the warm water of the tropics, flourish in abundance.

The Malays collect certain species which, boiled down, produce a glue or kind of gelose, known under the name of agar-agar, and of which China uses a large quantity.

In lower Cochin China, the part most fertile, and which belongs to France, they collect the algæ, to which they give the generic name of rau-cau, which is synonymous with " marine pot-herbs." They are collected principally on the rocky parts of the Asiatic continent, in the Gulf of Siam, the islands of Pho-Cok, Poulto-Condor, and, in fact, all along the indented coasts traversed at a short 
distance by the steamers which quit Saigon for Tonkin and China.

There is another species of algæ which has not the same utility, but which has a certain relative importance, as it is used medicinally, being administered to patients in different forms of drugs, cataplasms, moxas, etc. This species is called hai-toc, or "beard of the rocks." It has a fine green colour. The filaments are very slender, and are agitated in the manner of a fish's tail by the least movement of the water. The large and immense roadstead of Touranne contains great quantities. This hai-toc is found at shallow depths, attached by preference to old pieces of wood, piles, etc.

The Annamites designate the gelatine obtained from seaweeds by the name of tao. The Malays call it, as already stated, agar-agar. It is not prepared with the same care as in China and Japan, and is only shipped to China, in consequence of its low price.

The Annamites give the name of rau-cau to several species of algæ (Conferva corallina, Gelidium spiniforme, etc.) which they collect from the rocks on the islands of $\mathrm{Cu}-\mathrm{lao}-$ Khai (province of Binh Thuan) and Cu-lao-ré (province of Quang-ngai). They are known in Chinese medicine under the name of hai-thao.

Fifteen hundred grammes of rau-cau yield about two litres of seaweed jelly, which is much used for food purposes, after adding sugar, spirit, or other flavouring to suit the palate. This jelly also serves to make the gelose, or seaweed isinglass, which has been popularly employed of late years in France for culinary purposes, by confectioners, for sizing fabrics, and for preparing gold-beater's skin. The best seaweed is obtained from the island of Cu-lao-ré. The first-quality gelose, known as rau-cau-chon-vit, is white 


\section{The Commercial Products of the Sea.}

and transparent, and costs $£ 2$ the picul of I 33 lbs.; the second quality is only about half this price. The product obtained in Cu-lao-Khai is very inferior.

Seaweeds enter also into the food products of the Cochin Chinese. They whet the appetite with them when highly seasoned with garlic, mixed with fish water; and they form the celebrated sauce "Noachman," of a strong and repulsive odour, which is exported to all parts of the far East.

China, with its immense seacoast, estimated to be not less than 800 leagues in length, is very favourable for the collection of seaweed, which grows in great abundance in the sea; but the enormous demand for so numerous a population requires that the fishing should be carried on daily and without ceasing. This naturally tends to diminish the quantity obtained.

The collection or fishery is carried on in small boats with sails of platted reeds. It is prosecuted from the island of Hainan up to the Gulf of Petcheli, as well as the islands of Formosa, Chusan, Lieou Keou, etc. These little boats, manned frequently by an entire family, occupy themselves not only in the fishing of seaweed, which they detach from the rocks, but in the intervals obtain fish by large bait suspended from a bamboo pole, maintained perpendicularly by a line below. The continued movement of the bait by the waves renders the fishing very successful.

The second quality of algæ is obtained in a less tedious and difficult manner, by means of hurdles formed of branches of bamboo; they are the kind of fascines which the navigator notices in the creeks of rivers and islands, on the beaches and in the roadsteads, as well as the embouchures of all the great rivers where the tides reach a certain elevation. The seaweeds, borne by the passing 
waves at high water over these obstructions, are left behind when the tide falls.

One cannot be surprised at the large and important consumption of seaweed for food by the people, when we consider that, besides the quantities collected on their own coasts, the junks, the sailing vessels, and steamers bring from Japan to China thousands of tons annually, to the ports of Shanghai, Tient-sin; Neuchang, etc. These bales, transferred to boats, are carried up the Yang-tse-kiang to the most distant towns of the empire, such as Ho-nan and Setchuen, and even to Thibet.

For food purposes the seaweed, as in Cochin China and Japan, is mixed in soups, with rice, fish, and vegetables in general, and forms the celebrated cabbage pak-soeij, or pe-tsay in mandarin language.

The seaweeds not only communicate to food the salt with which they are naturally impregnated, which is a great economy for the poorer classes, who have to pay dear for it the further they are removed from the salines, but also a certain aromatic flavour of the sea, which resembles the taste of dried and fermented fish, so much in use among the numerous populations of the extreme East.

The English give to the seaweed gelose the name of isinglass, and the people of Canton call it tow-kao, while the jelly in a liquid state they call ghu-kao.

This isinglass of the first quality is made in the form of filaments. The gelatine made with it is white and transparent, and is employed in a number of industries. It is used by bakers and pastry-cooks for making biscuits, macaroons, and confectionery; by paper-makers; in stiffening the light and transparent gauzes, in the fine silk which is used for making fans, screens, hangings, etc. It is on these stuffs, so well stiffened, that the painters produce 


\section{The Commercial Products of the Sea.}

such beautiful designs in colours incomparable for their freshness and brilliancy.

The second quality of this seaweed isinglass is of a darker tint, and consists of the deposit in the basins in which the cooking has been carried on. It is used, like the liquid paste obtained from it, by makers of paper umbrellas and parasols, and paper lanterns, to smear the fine stretchers of bamboo on which they are formed. When thoroughly dried, these articles of such extensive use acquire an impermeability of long duration. But, unfortunately, predatory insects are very fond of this size, and a single night . frequently suffices to destroy these articles, exceedingly cheap and highly useful to all the Chinese. At Canton, as at Yokohama and Osaka, we find transparent sheets of gelatine made with this seaweed product, which are superior to those of European manufacture, inasmuch as they are not affected by the action of heat or moisture.

The seaweed isinglass of Japan is a gelatine as light as the pith of the elder. It has neither odour nor flavour. It is made by macerating and boiling down different kinds of seaweed, principally the Laminaria. The leaves are grated with sharp cutting instruments, which cause the green outer bark and saline particles to deposit.

The seaweed is then boiled slowly for about I 8 hours, and the mass left to cool, when it looks like fish-glue. The upper portion, which is the best quality, is turned out on boards to dry.

The gelose of commerce, or Japan isinglass, is also obtained from Gelidium spiniforme, and is made in the form of small sticks, transparent, but of a rough aspect. Steeped in cold water, it swells considerably without dissolving. It dissolves, on the contrary, readily in boiling water, and forms a jelly on cooling. It is this property which has rendered' 
it a food substance. After adding sugar, liqueurs, or aromatic flavourings, it is strained through a cloth and put into moulds. Gelose is also employed for various industrial purposes.

Under the name of mat, Porphyra vulgaris, reduced to a jelly by boiling, is also used like gelose for food by the Annamites.

The marine plants which are employed as food and in different industries in Japan are the following :-

The Ama-nori (Porphyra vulgaris), which is found on the coasts of different provinces. The best is that which is collected at Sinagowa, in the Gulf of Yedo, province of Musashi.

The wakame (Alaria pinnatifida), which is met with on nearly all the coasts of Japan. It is simply dried and sent into commerce.

The kombou (Laminaria saccharina), which is one of the principal products of Hokkaido. It is eaten in different ways : boiled, broiled, or dried and reduced into straight or quadrangular strips. It is largely exported to China.

Arame (Capea elongata) is found principally in the seas to the south of Japan. When dried it will keep a long time. In former times this plant rendered great service to the people during a famine which desolated the country.

The hijiki (Cystosura) is met with also in the same seas, and includes two varieties, one short and the other long. It is dried for use. That which comes from the province of Isi is the most esteemed.

Awo-nori (Emteromorpha compressa) comes from the same quarter; that of the province of Awa is considered the best.

Tenkusa, or Tokora tenkusa (Gelidium corneum), is col- 


\section{The Commercial Products of the Sea.}

lected in the seas of the different provinces of Japan. It is dried after having been first well washed in fresh water. When it is to be eaten, the dry seaweed is plunged in boiling water and dissolved. The liquid is then filtered, to separate any foreign matters, and left to cool. It solidifies, and is then easily cut up into pieces at will. It is eaten generally in hot weather.

There is another mode of preparation, which consists in exposing the jelly to the intense frost of a winter's night. It congeals and hardens, and then bears the name of "kanten," and may be kept till the following summer. - It is employed for making pastry, and cooks use it for preparing certain dishes. Besides its alimentary uses, this seaweed serves to make paper and many other things.

Hondawara (Halochloa macrantha) is found on the seacoasts of many provinces. It is salted and eaten with vinegar.

Tosaka-nori (Kallimenia dentata) takes its popular name, Tosaka, from its resemblance to a cock's comb. It is found principally in the seas to the south and east of Japan.

Funori (Glacopeltix intricta) is found on the coasts of many provinces. It is found in commerce in the dry state. When boiled and made into size, weavers use it to stiffen their thread. In ceramic work it is also employed for painting on porcelain; it has also many other uses. That which comes from the island of Hachijo and the province of Satsuma is considered the best.

Another larger marine plant, called tsunomata (Gimnogongrus pinnatatus), serves for the same uses.

Sómen-nori (Nemalion vermicularia) is collected in the interior sea of Shitoku; it is eaten salted, but can be dried in the ashes so as to keep it. 
Matsuba-nori takes its popular name from its resemblance to the leaves of the Matsuba pine. It is good to eat.

Okitsu-nori: of this there are two varieties, a large and a small. It is dried after being well washed in soft water.

Of miru (Codium tomentosum) there are many varieties, as the nagamiru, hiramiru, etc.; the first named comes from the province of Awa, the second from Satsuma. It is eaten raw or salted, and may also be kept by drying it in ashes.

Suizin-nori (Phillederum sacrum) is one of the famous products of Hiya ; it appears in commerce in the form of thick dried leaves.

Mozuku (Mesoglara discipiens) is obtained in the seas to the south and east of Japan. It is eaten raw, flavoured with vinegar, or dried and preserved. That which is held in the highest reputation comes from the province of Awa.

Japan is certainly the most favoured country where these seaweeds thrive with greatest luxuriance and abundance, and where the population carry on the fishery, and the collection every year is most considerable and productive.

It could scarcely be otherwise. The territory of Japan is formed of four principal large islands, Niphon, Yesso, Sikok, and Kiusiu; its superb sea commences a short distance from Nagasaki, bathes the numerous territories of powerful daimios, and extends up to the banks of the grand and populous town of Osaka, with its numerous canals, termed by strangers the Venice of Japan. If we add the 1800 or 2000 islands and islets which we find in the Sea of Japan, in the Pacific Ocean, and the inland sea, we have some idea of the harvest obtained by 


\section{The Commercial Products of the Sea.}

an incessant fishery for these marine plants, as well as for fishes, crustacea, mollusca, polypi, etc.

It is in some of these deep seas, with submerged earth, the effect of the action of formidable volcanos, dreaded by mariners, that is found flourishing a much-appreciated genus of algæ, the Laminaria. These often attain extraordinary dimensions; some have been measured 500 yards in length. This fucus is naturally detached from its holding ground when it reaches maturity, and its spongy nature brings it to the surface of the sea.

The Japanese do not gather the seaweed in the same manner as the Chinese. In place of the fascines or hurdles already described, they drive large bamboos into the foreshore or beach, which extends out a great distance into the sea.

On approaching Yedo, the capital, numerous stems of bamboo may be seen sunk deep into the sand, and disposed in such a manner as to permit the seaweed to enter when carried on by the waves at high water. Once entered, shaken and tossed about for many hours, the long and solid lengths get entwined and twisted about the posts, and when the water retires they are left dry at low tide. Then carts begin to arrive in great numbers, and the scene is most remarkable and peculiar in its character. The people of the shores, so numerous, hurry down to the beach-men, women, and children. They push each other aside, and scramble, with loud voices; for the first who arrives has the best chance of collecting the treasures left by the sea, such as seaweeds, crustacea, shells. When the tide rises and the waves pour in, the people return to their dwellings, situated in long lines on the banks. The collection made during the day is exposed to the sun and wind to dry. The women are occupied in 
sorting the weed. They chop the leaves off with a knife, cut them into fine strips, and heap them up into piles, which have the appearance of a heap of moss, all which occupies much time.

Thus prepared, these seaweeds are the most sought after for food purposes. The common seaweeds, after drying, are formed into ballots, or small bales, by the men, and tied up with some of the stems, which are of great strength. These are then transported either to the towns and villages situated a long way from the coast, or shipped in vessels to China.

It can scarcely be doubted that at some future day, when our clever European cooks have at their disposal good, fresh, and young sprouts of certain species of algæ, they will succeed in preparing useful dishes, which, in winter especially, will render signal service to the poorer classes when fresh vegetables are scarce. Again, seaweeds cooked and cut in thin slices, prepared as a salad, would be a simple and novel preparation. Prepared in the manner spinach is done in France, or with some sauce, which would remove the salt-water flavour, they would form a dish appreciated by all.

In Japan, as we have seen, several kinds of seaweed are used as food, and form important articles of the trade with China. Generally they are natural products, which have only to be collected; but in certain cases their growth is increased by some ingenious contrivance, devised for the purpose of producing their development under the most favourable circumstances.

In the neighbourhood of Tokio, where the water is shallow, long rows of branches of the Quercus serrata, Thun., are placed in the bottom of the sea during spring. In June or July, small buds of a reddish colour appear 


\section{The Commercial Products of the Sea.}

upon the branches; two or three months later, they have grown into soft round leaves, apparently similar to stems, and several inches in length. These stems now rapidly flatten out at the ends into broad leaves, which are taken off every alternate day all through the winter, until the end of March. At this period they become hard, unfit for use, and fall off during the summer months. The quality of this seaweed depends very much on the weather, and is best when frequent rains and falls of snow have rendered the shallow water more or less brackish. Too large a proportion of sweet water is unfavourable to the growth of the plant. A century or two ago it was gathered in large quantities at the mouth of the Sumidagawa, near Asakusa in Tokio; but as the river carried down with it a large quantity of gravel, its mouth advanced more and more into the sea, and the water near Asakusa becoming too fresh, the plant disappeared. Owing to this circumstance, the above-described mode of cultivation was instituted; the weed, however, has preserved its former name of Asakusa nori. The branches of Quercus serrata, on which the weed grows, are said to answer their purpose during three years; after that time, however, the bark comes off, and the weed does not grow any more.

Large shipments of cumboo or seaweed are annually made from the port of Hakodate, to the value of about $£ 16,000$. It is divided into three sorts-the best coming from Shimani and Yokadsu, the second quantity from Akish, and the third from Kusudu. This article appears in the Hakodate market throughout the whole year, with the exception of the winter months; and has two crops, the first from September to December, and the other from May to August. There is a good business also carried on with seaweed to China from Nagasaki and Kanagawa, 
about 80,000 cwt. being shipped annually from these two ports. At Shanghai the imports reach about $\mathrm{I} 70,000 \mathrm{cwt}$.

The trade in Japanese seaweed has year after year been assuming more ample dimensions in China. It is principally made use of by the poorer classes.

A very interesting product, called kanten or vegetable isinglass, a species of gelose derived either from Gelidium corneum, or Plocaria lichenoides, is made in China and Japan, and has been imported into this country, in the shape of flat and moulded square tablets and in bundles of strips, under the name of seaweed isinglass. It is known in Cochin China as hai thao, and has been used in France in several industries, especially in preparing gold-beater's skin, and for rendering tissues impermeable. It is only soluble in boiling water, and it takes up about 500 times its own weight of the fluid.

The mode of manufacture is as follows;-The seaweed called tengusa is carefully washed and afterwards boiled, so as to form a gluish decoction, which is strained off and put into square boxes. When cooled, it forms a stiff jelly, which can easily be divided into squares of a foot in length.

The manner in which the surplus water is removed is most ingenious, and worthy of notice. The jelly prisms are exposed in the open air during a cold night, and allowed to freeze. During the day the sun melts the water, which runs off, leaving behind what one might term the skeleton of a white horny substance, which is extremely light, and easily diluted in hot water; when cooled, it again forms a stiff jelly. This article, which is already to a certain extent known in Europe, can be applied to many uses, viz., for cooking purposes, for making bonbons and jellies, for clarifying liquids, as a substitute for animal 


\section{The Commercial Products of the Sea.}

isinglass, for making moulds used by the plaster of Paris workers, for hardening the same material-in short, as a substitute for all kinds of gelatines, over which it has the advantage of producing a firmer jelly.

Another seaweed, much used for industrial purposes, is the $f u$, resembling the carrageen moss, and applied to similar uses, such, for instance, as the sizing of the warp of silk goods.

Seaweed is not much used for food purposes in Europe. In Ireland, dulse (Rhodomenia palmata) is either eaten with butter and fish, or boiled in milk with rye flour. The Ulva latissima, or green laver, and the Porphyra vulgaris, or purple laver, are abundant on the British shores, and when boiled and served with pepper, butter, and vinegar, form an agreeable delicacy to many persons when eaten with cold meat. The London shops are supplied with it from the Devonshire coast. In Ireland it is known as "sloke." "Tangle," which is the young fronds of Laminaria digitata, is much eaten in Scotland; and at one time the cry of "dulse and tangle" was as common in the streets of Edinburgh and Glasgow as that of watercresses is in London at the present day.

Miscellaneous Uses of Searveed.-Various attempts have been made from time to time to manufacture paper from seaweed, but they have not been attended with any very great success.

In 1820 a patent was granted in Denmark for making paper from seaweed, which was alleged to be whiter, stronger, and cheaper than other kinds. In I 828' a patent was taken out in the United States, by Elisha Collier, for making paper from Ulva marina. In 1833 a patent was granted in France to Monsieur Tripot for making paper from seaweed. In 1875 two English patents were pro- 


\section{Seaweed and its Uses.}

visionally registered for making paper from seaweed, but these were never proceeded with.

Monsieur J. E. Brizot, of Toulon, states that to prepare paper from seaweed, it is necessary to pound the root part of the algæ, to break off a kind of fibrous outer coating which does not bleach effectually. It is then washed to remove the sand and earth which are often found adhering, and beaten well, after which it is placed in a reservoir of water mixed with sulphuric acid. Seaweed is naturally tough and stiff, owing to the number of cellules which it contains ; to render it supple for paper-making, it must therefore be steeped in an acid bath. In taking out the stuff from the reservoir, it should be removed with a wooden spade, pierced with holes, so that the acid water may be preserved for use again. The paper pulp may be placed in osier baskets to drain off the moisture. The filaments of the leaves should not be employed for white paper, as they do not bleach well. After cleansing and treating with the acid as already described, it only remains to bleach the material with chloride of lime till it is of the whiteness required.

Chevalier Claussen, when treating common seaweeds with alkalies, found they were entirely dissolved and a soapy compound formed, which could be employed in the manufacture of soap.

A patent was taken out some years ago by Mr. T. Ghislin for utilizing dissolved and pressed seaweed, under the name of laminite, in making imitation horn, moulded for the handles of cutlery, for sticks, picture-frames, book-covers, etc. It was not followed up to any extent.

The New Zealanders employ the large pods of a species of seaweed to store the whale oil which they use in the lamps of their sleeping houses. These, when filled, 
338 The Commercial Products of the Sea.

hold about a quart each, are tied up at the neck with flax fibre, and resemble in appearance a bottle of caoutchouc.

The large dried hollow fronds of a gigantic fucus serve as water buckets on the Pacific coasts of South America. Water pitchers used to be made by the aborigines of Tasmania of the broad-leaved kelp. They were often large enough to hold a quart or two of water. These and the shell of a species of Cymba were the only vessels they. had for carrying water. 


\title{
( 339$)$
}

\section{CHAPTER XIII.}

\author{
MARINE SALT.
}

Mode of obtaining sea salt-Salines of France, where situated-Statistics of production-Composition of the crude salt-Manufacture in the United States-Consumption of salt in various countries-Sea-salt works of Portugal-Salt manufacture in India a Government monopoly-Imports of foreign salt-Salt production in Cochin China.

ANOTHER commercial product from the sea is salt, obtained by evaporation, which is produced on a large scale in many quarters, especially in India, on the coast of France, in Turks Islands, and other localities. To obtain this salt a certain quantity of sea water is collected in reservoirs, constructed on the seacoast, which are termed salines, or salt marshes, where it is evaporated by the combined action of the rays of the sun and currents of air. As sea water contains only from two and a half to three per cent. of salt, a very large quantity of water has to be submitted to evaporation to obtain the salt of commerce. Notwithstanding this, the operations are carried on upon so large a scale, and the work is so arranged, that the salt is produced at a very moderate price.

France has about 82 salines, or salt marshes, occupying a surface of about 48,500 acres. These are situated, one 


\section{The Commercial Products of the Sea.}

on the Channel coast, 36 on the shores of the ocean, and 45 on the coasts of the Mediterranean. These consist of one or more reservoirs, into which the sea water is passed. Those of the south are greatly superior to the others, because they are better managed, and the climate is more favourable for evaporation.

The sea water is introduced, either by means of a canal of the level of the sea banks, or by means of hydraulic machines in other cases, into a reservoir, which is shallow and of great extent of surface, so that the liquid may be subjected to the action of the sun's rays. In this reservoir, when the evaporation commences, the water passes off slowly into a series of rectangular basins, less deep, where it continues to concentrate, after which it passes into a trench which conducts it to the great wells, called the wells of green water. Pumps then raise it into a second trench, by which it is carried into another series of evaporating basins, called interior heaters, from which it passes into the reservoir, and from thence by a third trench into more wells, called the salt wells. Here the sea water marks $22^{\circ}$ to $24^{\circ}$ of Beaume's areometer. The pumps then pass it into a fourth trench, which carries it into new basins, smaller than the preceding ones, called salt tables. In these tables, where the liquid mass is not above five or six centimetres of depth, the salt is deposited. When the principal part of the water has left the product, the water is carried off by the canal to the sea, and a fresh quantity of condensed salt-water is brought into the salt-pans. The water is renewed daily or every two days, and this operation is carried on during all the fine weather, that is, from April to September. When the bed of salt is of the thickness of four or five centimètres, it is collected or shovelled up. For this purpose the masses of salt are left 
to dry, and then collected with spades into long heaps or piles, which are called camelles. This operation is only carried on two or three times during the season. Finally, after long drainage, the heaped salt has parted with all its water, and is ready for passing into commerce.

The salt of the salines of the Mediterranean is in the form of very large and white crystals, and of a very fine purity. That of the salt marshes of the ocean is in the form of small grey crystals, and known in commerce as grey salt. It owes this colour to the earthy particles belonging to the basins, where it is collected daily.

To convert it into white salt it has either to be washed or refined, in order to remove the foreign substances which it contains. By the first process it is merely washed with water saturated with pure salt, after which it is drained and dried in stoves. By the second process, and by which very fine and white table salt is prepared, the grey salt is dissolved in ordinary water; the magnesia contained in the solution is precipitated with lime; it is then filtered and evaporated in shallow boilers.

The salt marshes worked in France are in the Bouchesdu-Rhône, and on the borders of the ocean, principally at the island of Ré, in the Landes, Charente-Inférieure, and Loire-Inférieure. As the production of the salt marshes is variable, the price of salt also fluctuates. The average may be taken at $2 \frac{1}{2}$ francs per roo kilogrammes, to which has to be added $12 \frac{1}{2}$ francs duty, bringing up the price to 15 francs. According to the official statistics, the consumption of table salt in France in 1876 amounted to $301,328,000$ kilogrammes, representing a value of $45,199,200$ francs ; and the exports were I,862,000 quintals, value $3,000,000$ francs, making the total commerce in salt, duty paid, amount to nearly $£ 2,000,000$ sterling, besides a good deal employed in agri- 


\section{The Commercial Products of the Sea.}

culture, the fisheries, and chemical industries, on which no duty is paid.

Marseilles is a great entrepôt for the trade in marine salt in France. In 1877 the deliveries were over 78,000 tons, of which 17,400 tons were exported, 39,000 tons locally consumed in the chemical and soap works, and 12,000 tons employed in the fisheries.

The following is the composition of the crude salt of the south and west of France:-

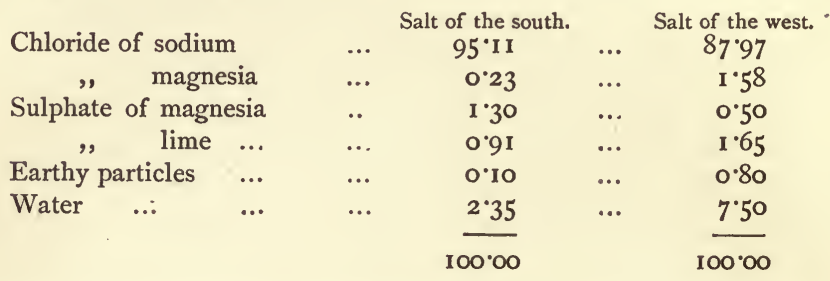

The annual average production of marine salt in France in the ten years ending 1876 was as follows :-

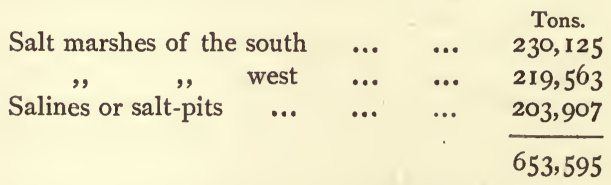

The quantity delivered for consumption, duty paid, was 315,549 tons; exported abroad, I09,633 tons; delivered free for various manufactures, 183,763 ; total, 608,945 tons. The tax on salt in France was raised to $12 \frac{1}{2}$ francs the 100 kilogrammes by the law of the 2 nd of June, I 875 .

On some of the coasts of the Channel, marine salt is obtained by a process quite different from that adopted in the salines. During low tide the sand of the beach is collected, washed with sea water, which gives a very concentrated briny liquor, and this is evaporated to dryness 
in small boilers heated by wood. The saline mass thus obtained is placed in baskets, which are suspended over the boilers during the subsequent concentration. The salt, moistened by the aqueous vapour, gives up almost all its deliquescent salts. It is then stored, and only sent into commerce after some months' keeping. During this time it loses a further 28 or 30 per cent. of its weight. The salt obtained by this method is very white, and fine like snow. It passes under the name of igniferous salt.*

In certain cold countries, especially in Siberia, where the rigour of the climate does not allow the practice of salt marshes to be carried on, recourse is had to freezing for obtaining salt. This process rests on the property which water, saturated with salt, possesses of passing into the solid state at a much lower degree than pure water. If sea water is exposed to an atmosphere some degrees below zero, it separates into two parts-one solid, which is the water pure or nearly so; the other liquid, which is the water more or less charged. By removing the ice flakes and repeating this operation several times, a liquor is obtained more or less concentrated, from which it is easy to obtain the salt by means of evaporation ; but this salt is always very impure.

The total production of salt in the world it is quite impossible to estimate, because it is not solely an industrial manufacture; but in many localities, and especially in hot countries, it is found natural and spontaneous. However, it is generally believed that in Europe alone the produce is about 3,000,000 tons. In France the mean average production is set down at about 650,000 tons, divided as follows :- Salines of the south, 300,000 tons; salines of the west, 250,000 tons; salines of the east and the Pyrenees, * Maigne's "Arts and Manufactures." Paris. 


\section{The Commercial Products of the Sea.}

I00,000 tons. This production might easily be doubled or tripled, but it is limited for want of markets. About 540,000 tons pass into consumption, apportioned as follows :- 370,000 tons for food purposes, 50,000 for chemical industries, 60,000 for the fisheries, 60,000 tons for export, and 7000 for salting fish under the surveillance of the Customs.

Salt is largely produced in California, mostly from sea water.

Marine salt was made in Austria in 1876 to the amount of 344,862 metrical quintals.

In the Portuguese possessions of St. Thomas's and Prince's Island, Angola, Mossamedes, and the islands of Cape Verd, salt is made.

Marine salt, obtained on the coasts of the Gulf of Pechihle, China, by spontaneous evaporation of the sea water in the salt marshes, is, like saltpetre, the property of the State, and subject to special laws.

Salt is made in the Portuguese possession of Goa, in India.

The principal manufactories of salt from sea water in the United States are along the shores of Cape Cod and at Nantucket.

In order to obtain salt by evaporation, the sea water is pumped by windmills into shallow wooden pans; or, in countries where it can be done, it is allowed to flow over a salt marsh, which has been previously prepared by removing all vegetation from its surface. The salt water is first secured in a large shallow reservoir, where it is allowed to become moderately concentrated by the action of the sun's heat and the winds. From this it is conducted, by a system of sluiceways, into other reservoirs or evaporating basins more carefully constructed, and in these it deposits the 
lime salts. Finally, it is led into basins where it begins to deposit the salt, the water in these compartments being only a few inches in depth. When the land is sufficiently below the level of the sea to allow the water to flow from one set of basins into the adjoining ones, of course the process is rendered quite easy; but if it is not low enough, the brine is raised at various stages by pumps moved by windmills. Salt produced in this way is called bay salt, and can only be made in very dry countries, as a few hours' rain would spoil the labour of weeks. When wooden tanks are used, they are generally protected from the rain by coverings. The tanks are made about ten feet square, and a foot deep. The roofs are moved off and on by the aid of wheels running on rails, or, what is more common, two roofs are fastened together by their corners, and so arranged that they will turn about on a pivot, covering or uncovering two tanks by one movement.

The average consumption of salt per head in various countries has been roughly estimated to be as follows :-

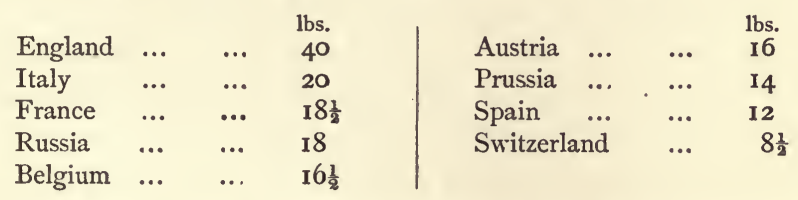

No marine salt is made in the United Kingdom, but the manufacture of salt reaches about $1,500,000$ tons, nearly half of which is exported, chiefly to India and the United States.

Sea salt is made to a small extent in Algoa Bay and other parts of the Cape Colony, and in Australia.

The sea-salt works of Portugal are very extensive, and produce annually 250,000 tons of salt, which is in great request. The centres of the manufacture are Setubal, 


\section{The Commercial Products of the Sea.}

Lisbon, Aveiro, and Algarve. The arrangement of the salines at Setubal is very simple. They form a vast reservoir, divided into squares, separated from each other by roads a little more than a yard wide, and all communicating with a main reservoir, which stores up the sea water. The water is admitted directly into these square tanks, where it evaporates and deposits its salt without any previous concentration or purification. In autumn the water is allowed to flow in so as to cover the entire salt marsh to the depth of 50 or 60 centimètres. In spring this water evaporates, and in the month of June the separation roads appear above the surface. The tanks are then cleaned out, left to themselves, and recharged from time to time with new supplies of water. Under the influence of the north-east winds which prevail at this season, the evaporation is very rapid, and after about 20 days each tank is covered with a layer of salt an inch and a half thick and almost dry. This is the first crop. The salt is collected, sea water is introduced anew into the reservoirs, and 20 days afterwards a second crop is gathered. But this is not evaporated to dryness, and the salt is covered with an inch or so of mother liquor, which is left behind on gathering the salt. If the season is favourable, a third crop is attempted, and in September the marsh is flooded over for the winter.

In India the salt manufacture is a Government monopoly, and the tax produces about $£ 6,250,000$ annually. The native production would appear to be hardly sufficient, since duty amounting to $£ 2,235$,000 was received on foreign salt imported in 1876 . The duty levied varies from I $s$. to $6 s$. $6 d$. per maund. The annual imports of foreign salt range from 600,000 to 900,000 tons.

The quantity of salt imported and delivered from salt works in the Bombay Presidency in the year ending March, 
I 867, was 5,403,7 I 8 maunds, of which 4,597,3 I 2 maunds were sea salt. There were 354 salt works in operation.

Extensive salt fields exist at Shimpagah, a short distance above Mandalay, on the western bank of the Irrawaddy river. It is also obtained at other places in Burmah on a small scale. Large quantities could be manufactured at Shimpagah, but imported salt is fast taking its place in the market.

The manufacture of sea salt is carried on on the coasts of Cochin China, and bids fair to become a prosperous industry. There are salines worked at Soc-Trang, Baria, and Bien-Hoa.

The following is an estimate of the cost of carrying on the manufacture at the salines of Baria. Each hectare (about two acres) of saline is subdivided as follows :-

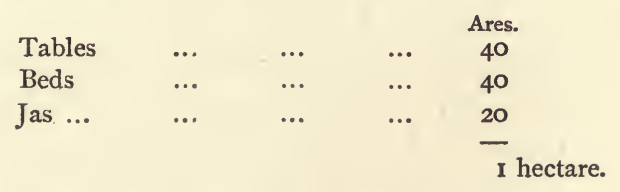

From which it results that to establish 200 hectares of "tables," it requires not less than 250 hectares of land. The working of one hectare of tables, or two and a half hectares of saline, involves the following expenditure:I 500 francs at first, for feeding the workmen during the formation of the salines. If the first collection of salt is good, the workpeople are paid a second sum of 1500 francs, and the collection of salt is given over to them for their own benefit. The capital thus advanced amounts to 3000 francs. The second year the proprietors work on their own account, and collect probably salt to the value of 2000 francs. After deducting tax, etc., there remains about $\mathrm{I} 200$ francs of net revenue on the capital advanced, 


\section{The Commercial Products of the Sea.}

at different stages, of 3800 francs; that is to say, about 36 per cent.

If the result of the manufacture or collection of salt is unfavourable, the salt makers improve their work during the second year without any further advance than the resulting product obtained for their own benefit.

It results from these figures that to work I0o hectares of salt-pits, or 250 hectares of land, requires a capital of about 400,000 francs $(£ \mathrm{I} 6,000)$.

In Western Australia salt is collected from the Canning in its natural state, and it is evaporated from the water on the salt lakes on Rottnest Island, from Poolenup Lake, and from Lake Muir. The salt from Rottnest, evaporated at $226^{\circ} \mathrm{F}$., contains $95^{\circ} 9$ of pure chloride of sodium.

The salt trade of the Bahamas and Turks Islands has been almost paralyzed by the high rate of duty levied in the United States. In I873, salt to the value of $£ \mathrm{II}, 080$ was shipped from the Bahamas; in 1876 it had fallen to $£ 4,639$. In several of the out islands of the group the inhabitants formerly relied upon the proceeds of salt-raking, and the islands upon which salinas are situated are not, as a rule, capable of producing anything else. For the last few years the industry has entailed a loss on all those engaged in it, and there is no hope of their condition being improved until the duty is reduced or entirely abolished. 
PART III.

MARINE CONTRIBUTIONS TO ART. 



\section{CHAPTER I.}

TORTOISESHELL AND THE TURTLE FISHERIES.

Marine tortoiseshell-Commercial classification-Land tortoises-Employment of tortoiseshell-Mode of working it-Various applications of tortoiseshell -Statistics of imports-The green or edible turtle-Food uses of the flesh and eggs.

IF the earth is made by man to give up its gems and precious stones for art, and its mineral and vegetable substance for the art workman and the art manufacturer, the sea is also constrained to yield its pearls, its coral, and amber for the jeweller; its mother-of-pearl and other shells for inlaying and carving, and its tortoiseshell for ornamental work. It also yields treasures for the painter, the sculptor, and the art manufacturer, for designs and studies; whilst its objects of beauty in corallines, shells, and seaweeds adorn the cabinets of the naturalist, the collector, and public museum. It is to be regretted that even in this scientific age much ignorance still prevails as to the nature, sources of supply, and mode of treatment of many of these marine substances-so worthy of close study and investigation.

A little scattered information on some of the materials mentioned has, from time to time, been published; but they seem to require more systematic description.

The horn-like epidermoid plates which cover the dorsal buckler or carapace of the sea-tortoise, are in some species 


\section{The Commercial Products of the Sea.}

so fine and of such beautiful colours as to be employed for various purposes of art. It is only those, however, of the hawksbill and caret species that possess any great trade value; the plates being stronger, thicker, and clearer than in other varieties. There are usually I 3 plates on the carapace, called collectively in trade "the head,"-four on each side, and five on the back; the last bent in the centre. Of the side plates, the two middle are the most valuable, being the largest and thickest; those on the back and margin, known as "hoofs" or "claws," are comparatively of

FiG. 26.

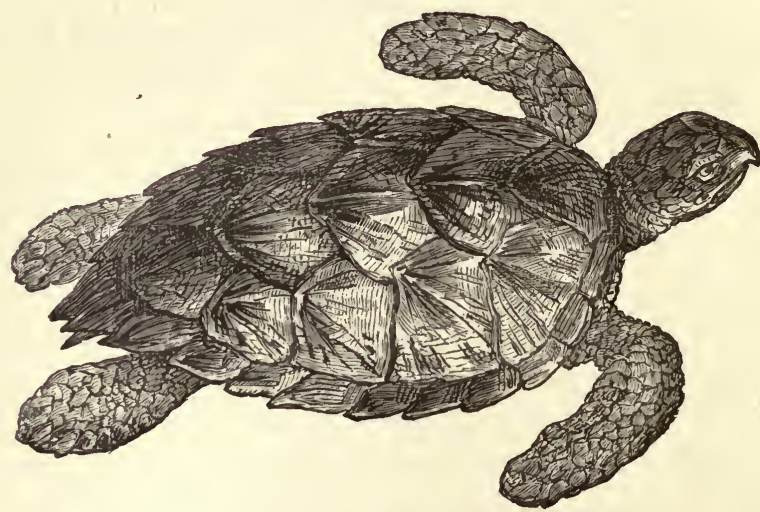

Hawksbill turtle.

less value. There are 24 marginal pieces round the edges, which are termed the "feet" or " noses." The lamellce or plates vary in thickness from one-eighth to one-quarter of an inch, according to the age and size of the animal, and weigh collectively from four to six pounds or upwards. In an animal of ordinary size, about three feet long and two and a half feet wide, the largest plates weigh about nine ounces, and measure about thirteen by eight inches, and are a quarter of an inch thick in the middle. 
Tortoiseshell is usually detached from the carapace and bony framework by placing heat below, or sometimes by soaking it in boiling water. In the West Indies the plates or blades of tortoiseshell are removed by burying the carapace in the ground, or in the sand, for IO or I 2 days. When taken up the blades fall off, and the 13 dorsal pieces are easily collected, forming the before-mentioned, viz., eight "sides," two "hoofs," one "skull," and two "main plates." A small hole is bored in each, so as to string them together, for no experienced buyer will purchase a case of tortoiseshell unless the whole of the shell is thus presented.

The "feet" or "noses" of the tortoiseshell are chiefly in demand in China. The blades of the hawksbill or imbricated turtle are very transparent, and more beautifully mottled than those of the caret turtle; the scales of the latter are thinner, and are not used for the same purposes, but employed for veneering and inlaying work. The shell of the hawksbill has a blackish green colour, with yellowish spots; while the colour of the plates of the caret turtle is blackish, with irregular transparent spots of golden yellow, and veined with red and white, or of a brownish black, of various shades.

The plates of the green or edible turtle are thin and flexible, and of slight manufacturing use. Their general colour is dull palish brown, streaked with patches of black, but not exhibiting those strong beautiful colours which so peculiarly distinguish that of the imbricated tortoise. The scales of the carapace of the loggerhead turtle are of a. dark chestnut brown, very thin, and neither clear nor beautifully coloured; hence they are of little value : but latterly some use appears to be made of them, for the imports of turtleshell (as it is commercially named, in contradistinction to tortoiseshell) have averaged in the last 


\section{The Commercial Products of the Sea.}

four or five years in value $£ 6000$, worth wholesale about $5 s$. or $6 s$. a pound; the range has been, however, as low as $8 d$. to 3 s. per pound for turtleshell.

Of the shells of the smaller land-tortoises not much use is now commercially made; and they find no sale in this country. They were formerly worked up in the manufacture of ornamental articles, such as tea-caddies, workboxes, card-cases, side-combs, etc.; but they have fallen almost into disuse, being superseded by the marine tortoiseshell. In the Cape Colony the dorsal shield or shell of a small land-tortoise, about three inches in diameter, which is very beautiful, is made into a smuff-box. This kind is used, more especially on the continent, in buhl furniture, and occasionally in England for inlaying tables, cabinets, picture-frames, and other ornamental articles; a suitable foil being placed below it, to give lustre and colour. The shells of land-tortoises are used by the Indians of North America for pots, scoops, and rattles.

By holding pieces of shell before a gentle fire, or, what is better, by steeping them in boiling water, they can be so far softened as to be pressed into moulds.

The moulds employed for this purpose are double, so as to contain the shell between them. Both parts of the mould being made warm, the piece of tortoise-shell, which is made warm and pliant, is placed on the lower half of the mould, and the counter-mould is closed upon the shell. The mould is then put into a press, and the upper half is gently pressed down upon the shell. The whole is then put into boiling water, and as the shell becomes more and more softened, the upper half of the mould is, from time to time, screwed down upon the shell, until at length the shell is completely pressed into the lower mould, and is itself closely pressed by the upper mould; so that any 


\section{Tortoiseshell and the Turtle Fisheries. 355}

devices that may have been engraved or embossed upon the two halves of the mould leave corresponding impressions upon the shell. The mould is then taken out of the hot water and steeped in cold water for a quarter of an hour; after which the shell is taken out and is found to retain the form imparted to it by the mould.

When two pieces of tortoiseshell are to be joined together, the two edges are bevelled or chamferred off, so that one inclined edge may lie upon the other. The edges are then scraped perfectly clean, contact with the fingers or any greasy substance being carefully guarded against. A piece of paper is then bound round the overlapped edges and fastened with string. A pair of tongs or pincers, something like hair-dressers' tongs, are then heated and applied to the shell, one jaw above and another beneath, by which the shell is grasped throughout the length of the seam or overlap. By holding it some time in this position the heat of the iron penetrates through the paper, softens the shell, and causes the two pieces to unite firmly. Sometimes two pieces of shell are united by means of boiling water. The two edges are overlapped, two pieces of metal are placed along the joining, the shell is placed in a press, and the whole is immersed in boiling water. As the shell softens, the press is screwed more tightly, by which the two pieces of shell become firmly united. In practice, when two pieces of tortoiseshell are joined, attention is paid to the colour and pattern of the surface, in order that the two pieces may agree in those respects.

Sometimes ornaments are made of what may be termed melted tortoiseshell, with very beautiful effect. The clippings, raspings, turnings, etc., of tortoiseshell are collected and put into moulds which are double; that is, a mould for the external surface of a box 'or piece of ornament, and 


\section{The Commercial Products of the Sea.}

another for the internal surface. When a sufficient quantity of small particles of shell is put into the lower mould, which is to form the external surface, the upper mould is placed upon them, and gently pressed down by a screw attached to a frame which contains both moulds. The frame and moulds are then immersed in boiling water, and as the particles of shell become softened, the screw is gradually turned, so that the shell becomes pressed into a soft continuous film, occupying the whole of the space between the two moulds. The moulds are then allowed to cool, and the shell is removed from between them, when it is found to give accurate representations, in relief, of any objects which may be engraved on the moulds. This mode of manufacture has been carried to great perfection in France, from whence snuff-boxes in great variety are procured. The French have also made hollow walking-sticks of pure tortoiseshell, by joining strips of shell together, and moulding them round a central stick or core, which is afterwards removed.

The scales of the plastron, or under-shield, are of a yellow colour, and are used for many of the purposes of horn. This shell differs entirely in appearance, for instead of the mottled shaded colour with its varying tints and markings, it is of a bright yellow, resembling somewhat the "hoof," or connecting marginal pieces; but as these approach the upper part of the shell, they partake of its mottled colouring.

The under plates and hoof are used for the manufacture of the gold or amber-coloured semi-transparent combs so much admired abroad. The Spanish ladies will often give $£_{3}$ or $£_{4}$ for a comb of plain yellow tortoiseshell, while a similar one of the mottled kind would not fetch there, perhaps, more than 20s. or $30 s$. Such is the influence 
of fashion and taste. Works in this material are made either by cutting them out of the shell, or by soldering when softened by heat. Tortoiseshell is often veneered upon a body of wood, scraped to a uniform thickness, and attached by fine glue. The colours are rendered darker or brighter by various coatings of coloured varnish, or of metallic leaf placed under the veneer.

Tortoiseshell is worked upon like horn, and is usually softened or rendered plastic by placing in boiling water, containing a handful of salt to the quart, for about an hour before working; but there is no necessity for previous soaking in cold water, as with horn. In operating on the shell of young tortoises, the water has to be made salter, and the time of boiling should be less. Some articles are made by placing in brass moulds the raspings, turnings, and shreds of tortoiseshell. The moulds, to the number of I 2 to 20 , are then placed parallel in a boiler of hot water, and left till the softening and pressure show that the mould is filled; they are then taken out, and the objects polished and finished for sale.

In the process of manufacture, the material, being costly, is economised as much as possible. For instance, in making the frames for eye-glasses, narrow strips of tortoiseshell are used, in which slits are cut with a saw; the slits being subsequently, while the shell is warm, strained or pulled open, until they form circular or oval apertures, by the insertion of tapering triblets of the required shape. The same yielding or flexible property is made use of in the manufacture of boxes, a round flat disc of shell being gradually forced by means of moulds into the form of a circular box with upright sides. The union of two or more pieces of shells may'be effected by carefully scraping the parts that are to overlap, so as to render them perfectly 


\section{The Commercial Products of the Sea.}

free from grease (even such as might arise from being touched by the fingers), softening them in hot water, pressing them together with hot flat tongs, and then plunging the joint into cold water.

If, however, the heat is too great, the colours are much deepened, so as to become almost black, as in the case of moulded snuff-boxes; for tortoiseshell, being less fusible than horn, cannot be made soft enough to be moulded without some injury to the colour. Accordingly, the manufacturers never attempt to produce tortoiseshell combs with ornamental open work by means of dies, but in the following manner :-A paper being pasted over the tortoiseshell, the pattern is drawn on the paper, and is then cut out by means of drills and fine saws; the paper is removed by steeping in water, and the surface of the pattern is finished by the graver.

In making small side-combs, it is found worth while, in order to save a costly material, to employ a machine, consisting of a cutter working straight up and down, and of a bed (on which the shell is laid) to which is given a motion, advancing, by alternate inclination, first to one side and then to the other. By this means the teeth of two combs are cut at the same time; those of the one occupying the intervals of the other. Such combs are called parted, the saw not being used upon them. They are often made of fine stained horn instead of tortoiseshell, and it is difficult for the inexperienced eye to detect the difference.'

The appearance of tortoiseshell may be given to horn by brushing it over with a paste made of two parts of lime, one part litharge, and a little soda-lye, which is allowed to dry. This is the same as the Indian hair-dye, and acts by forming sulphuret of lead with the sulphur contained in the albumen of the horn, producing dark spots, which contrast 


\section{Tortoiseshell and the Turtle Fisheries. 359}

with the brighter colour of the horn. Artificial tortoiseshell is made by melting gelatine with various metallic salts.

The greatest comb-manufactory in the world is in Aberdeen. There are 36 furnaces on the works for preparing horns and tortoiseshell for the combs, and no less than 120 iron screw-presses worked by steam.

Forty years ago, ladies' back-combs-which were larger than ladies' bonnets are now-were made in England and the United States for the Spanish peninsula and South American markets. They were often a couple of feet wide, encircling two-thirds of the head, and from six inches to a foot high on the back, the top being wrought in open work ; to these the Spanish ladies attached their veils. As much of the work was done by hand and with the saw, and the polishing was entirely manual, the prices were high, averaging $£_{3}$ to $£_{4}$.

For modern uses thick tortoiseshell is more valuable than thin; but among the Roman's, who had a furore for articles inlaid with tortoiseshell, veneers were cut off it, and very beautiful work can be produced by this process. In veneering it is usual to apply fish-glue mixed with lampblack, vermilion, green, chrome, white or other colouring matter, at the back of the shell, both to heighten its effect and to conceal the glue or cement by which it is secured to the wooden foundation.

The uses of tortoiseshell for ornament are varied, and a very great number of articles, as must be generally known, are made from this substance. Brown and light-coloured tortoiseshell is imported from India and China to France for fans, the former costing about $25 \mathrm{~s}$. the pound, the latter as much as $£ 4$. Machinery has almost entirely replaced hand work in the cutting of the mountings for fans, with 


\section{The Commercial Products of the Sea.}

the exception of tortoiseshell and ivory. In China and Japan very beautiful cups and saucers are made from this material, little fancy boxes, cases for holding chopsticks, and such like. The artistic mode of lacquering, gilding, and ornamenting the tortoiseshell salvers, cups, and boxes, as practised in. Japan, has yet to be acquired here.

The Chinese are partial to tortoiseshell, but then they have peculiar notions respecting it. Tortoiseshell having white and dark spots that touch each other, and is as much as possible similar on both sides of the plate, is in their eyes much finer, and on this account more eagerly bought by them, than shell that wants this peculiarity. On the contrary, plates which are reddish rather than black in their dark spots, which possess little white, and are more damasked than spotted-in a word, in which the colours, according to the Chinese taste, are badly distributed-are less valued. This caprice of the Chinese makes them sometimes value single "heads" at unheard-of prices; such, for example, as go under the name of "white heads," and for the varieties of which they. have peculiar names.

Tortoiseshell was much used to decorate furniture by the Romans. According to Pliny, Carvillius Pollio was the first to apply tortoiseshell to ornamental purposes. The fashion for this style of decoration increased, and in the days of Augustus the patricians ornamented their doors and the columns of their rooms with this substance. Julius Cæsar found in Alexandria such a collection of the carapaces of the tortoise that he had them carried in his triumphal entry.

Strabo, Diodorus, and Pliny, all speak of boats made from the shells of tortoises. They are authors of un- 


\section{Tortoiseshell and the Turtle Fisheries. 36I}

doubted veracity, and we must credit the fact, although we are not furnished with any very definite idea of the manner in which they were built. The sea-turtle is sometimes found of sufficient size to make a small boat from the back shell, and of the gigantic luth (Sparges [Dermatochclys] coriacea) there is a carapace fully nine feet in length, preserved in the Sydney Museum, New South Wales. But the Egyptians could have known nothing of such monsters. They must have used the land-tortoise, and most probably had the art of welding together pieces of shell by means of heat.

Diodorus tells us that, besides furnishing food for the people bordering the Red Sea, they made of the carapace small boats to cross the Red Sea, utensils for holding various substances, and tiles for covering their dwellings.

"I have been told," says Dampier, "of a monstrous tortoise taken in the Bay of Campeachy, which measured four feet from the back to the belly, and six feet in width. The son of Captain Rock, 9 or Io years old, used this as a boat to go from the shore to his father's vessel, about a quarter of a league." Another voyager, Lemaire, states that, at Cape Blanc, the turtles are of such a size that some with the bones removed yielded a barrel of flesh, without the head, throat, tail, fins, tripe, and eggs, and would furnish a good meal to 30 men.-Firmin, "Voyage in Equinoxial Holland," page 8o.

The specimens to be seen in the Natural History Museums of Paris and London, give an idea of the monstrous size of some of these sea-turtles, so that there is nothing exaggerated in the accounts of travellers. But it is not these large turtles that are most esteemed for food; those of 10 or $25 \mathrm{lbs}$. weight are the best flavoured. 


\section{The Commercial Products of the Sea.}

At the first London International Exhibition, in $185 \mathrm{I}$, tortoiseshell bracelets, brooches, ornaments, circlets, and rings were shown by M. Philip, a Parisian manufacturer, who received a medal for them; but it is only lately that this species of ornament has come much into vogue here. This tortoiseshell jewellery, however, is neat, tasteful, and moderate priced, and is taking the place of the vulcanite and jet ornaments which have been so much worn. The tortoiseshell is moulded for these into earrings, brooches, bracelets, crosses, and other pendants, in which piqué gold ornaments and fancy devices are worked.

England imports annually large quantities of tortoiseshell, and maintains the monopoly of this artistic material. It would scarcely be believed that in some years upwards of 30 tons of this ornamental substance, valued at more than $£ 74,000$, are imported here, and on the average of years about 25 tons are received.

At the Paris International Exhibition of 1867 , among the countries which exhibited tortoiseshell were Holland, Dutch India, the Bahamas, and Tahiti. A French exhibitor at Nossi-be, who exports 6000 to 7000 lbs. annually, showed some fine plates of shell.

To show how widespread is the range of the marine tortoise, it may be mentioned that tortoiseshell comes to us from more countries than any similar raw ornamental substance. We receive it from India and China, the Eastern Archipelago and Pacific Islands, Australia, the West Indies, South America, and Africa. The Indian islands furnish the largest supply of tortoiseshell for the European and Chinese markets, the chief emporia being Singapore, Manila, and Batavia, from which 26,000 to 30,000 lbs. are annually exported. 
Tortoiseshell and the Turtle Fisheries. $\quad 363$

The imports into the United Kingdom and values in I 870 were from-

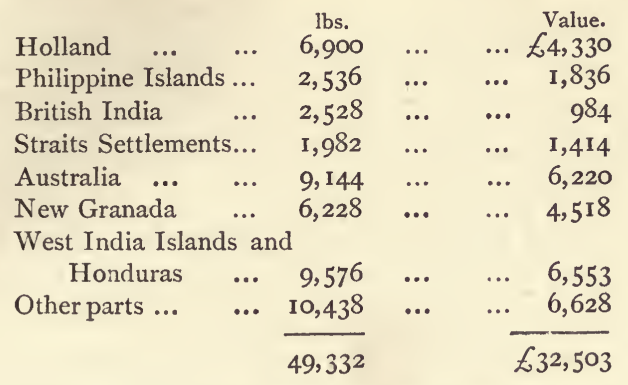

The average prices in 1870 were from I $3 s$. to I $4 s .6 d$. per pound, except Indian tortoiseshell, which was only worth $7 s .9 d$. per pound.

Tortoiseshell remained low in price for some years, as it is greatly dependent for its chief use, that of ladies' combs, on the fashion of the day in wearing the hair. A quarter of a century ago it often fetched $£ 33$ s. the pound; in recent years the average wholesale price has not been more than from I2s. to I 5 s., but of late there has been an increased demand, and a gradual upward tendency in prices is manifested. At one of the London monthly public sales, good dark-mottled shell on a light ground, free from scab, and thin red shell or dull colours, from Zanzibar, Bombay, and Singapore, fetched wholesale $28 s$. to $29 s$. $6 d$. per pound. Of West Indian tortoiseshell, 4000 to 5000 lbs. were readily sold at from 3 Is. to $4 \mathrm{I} s$. per pound for fair to good quality "hoof;" ordinary and medium, from $25 \mathrm{~s}$. $6 \mathrm{~d}$. to $32 \mathrm{~s}$.; and even inferior as high as II $s$. to $22 s$. per pound.

As much as 5000 and $6000 \mathrm{lbs}$. of tortoiseshell were exported from Mauritius Io years ago, but lately the shipments have dropped down to about Iooo lbs. 
364 The Commercial Products of the Sea.

The average annual imports of tortoise-shell into France have been as follows :-

In the ten years ending 1856

$\begin{array}{cccc} & \text { Kilogrammes. } & & \text { Value in francs. } \\ \ldots & 13,389 & \ldots & 730,096 \\ \ldots & 31,629 & \ldots & 1,251,922 \\ \ldots & 42,306 & \ldots & 2,078,910\end{array}$

Passing now to the food uses of the turtle-M. Lacepede well remarks that one of the best presents which nature has given to the inhabitants of equatorial countries, one of the most useful products which it has deposited on the confines of land and water, is the turtle.

The flesh of some species of marine tortoises, but particularly of the green turtle (Chelonia midas), is in the

FIG. 27.

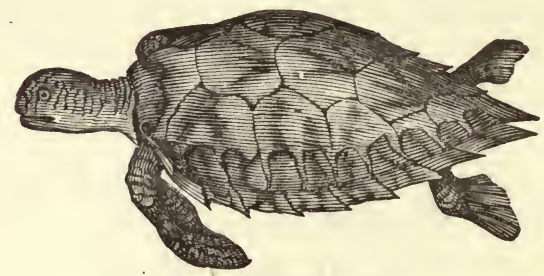

Green or Edible turtle.

greatest request as a luxury for the table, at least in England, and the animal itself is an object of commerce. The arrival of a cargo of "lively turtles" is by no means a thing of trifling importance. Of late years, the flesh is imported dried, which has placed it within the reach of general consumers. It is also salted in some quarters. All the turtles afford a considerable quantity of oil, which is employed for various purposes. In some of the West Indian islands it supplies, when fresh, the place of butter or salad oil for culinary purposes, and it is also used for burning in lamps.

Turtle would seem to have been first introduced in 
England as an article of food about the eighteenth century, for a record in the Gentleman's Magazine, under date August 31, 1753, shows that it was then a rarity; but they did not understand how to dress it. It states: "A turtle, weighing 350 lbs., was ate at the King's Arms, Pall Mall; the mouth of an oven was taken down to admit the part to be baked."

The locality for feasting upon the turtle now has been transferred chiefly to the precincts of the City; and the Ship and Turtle, Birch's in Cornhill, the Guildhall, and Mansion House, are the chief depôts of consumption. Steam communication too has greatly increased the imports of this reptile. About 15,000 are now introduced into our ports, and from thence to our kitchens, every year. They weigh from a quarter to three cwt., and may be valued in the aggregate at about $£ 8000$, or more. Not that all these shielded animals so arriving can be called "lively turtle," for the voyage has very often a damaging effect upon them, and they have to be brought into flesh before they can be dished up for an alderman's or nobleman's table.

Dr. Browne, in his "History of Jamaica," speaking of the turtle, says "it is delicate, tender food while young, but as it grows old it becomes more tough and gristly, and is not so agreeable to the stomach in those warm countries; the juices, however, are generally reckoned great restoratives, and often observed to heal and smooth the skin in scorbutic and leprous habits."

The flesh of the green turtle is employed in the West India islands generally, in all the maritime cities of the United States, Brazil, and Peru, in England, in Africa, the Cape Verd islands, and among the natives who inhabit the western coasts of Africa, Guinea, and Congo, the islands of Mauritius and Réunion in the Indian Ocean, 


\section{The Commercial Products of the Sea.}

at the English Presidencies of India, and in Australia. There is not a four-footed animal, a voyager tells us, the flesh of which the Japanese esteem like that of the kecame, or turtle.

The flesh of the turtle is thus, we find, a universal food, if we except some of the States of Europe, which do not seem to appreciate it as a delicacy. I may add that this has been so in all ages. Diodorus of Sicily, Pliny, and Strabo speak of it. The former named "Cheloniphages," certain people inhabiting islands at the entry of the Red Sea, whose principal occupation was catching turtle.

The flesh is cooked in all ways. It is made into soup; it is roasted; it is made into fricassees, stews, and pies. The eggs, intestines, bones, all are employed, and esteemed excellent.

There are in the turtle two pieces of flesh very white, compared to knuckles of veal. It may be larded and made into fricandeaux and patés, equal to those of Rouen or Pontoise. The turtle is, as it were, the fry of the sea, for every part of the flesh is edible. The bones, being easily saturated with the gravy, are left in the ragouts which are made, and the fat, which is very fluid, serves instead of butter or lard. The two most choice food preparations of the turtle in the West Indies are the soup and the boucan or plastron. The soup made there is flavoured with sherry, and seasoned with strong spices, capsicums, ginger, cloves, and nutmeg. It is considered to be excellent when, after having eaten, one is obliged to rest with the mouth wide open, and cool the fevered palate with madeira or port. So that to appreciate this fiery soup, the taste has to be acquired.

The plastron, or boucaneered turtle, is made by 


\section{Tortoiseshell and the Turtle Fisheries.}

mincing the flesh fine and cooking it in its own shell. Here is the recipe given for preparing and cooking it: "The plastron or buckler is the shell of the belly, on which is left three or four inches of flesh, with all the fat, this being green, and of a very delicate flavour. The plastron is placed in the oven. It is seasoned with lemon juice, capsicum or cayenne, salt, pepper, cloves, and eggs beaten up. The oven ought not to be too hot, as the flesh of the turtle being tender it should be cooked slowly. While it is baking the flesh must be pierced from time to time with a wooden skewer, so that the gravy may penetrate all parts. The shell is sent up to table, and the meat carved out from it. I have never eaten anything more appetizing or better flavoured." This is not the recipe of a royal chef de cuisine, or of an ordinary cook, but of Father Labat, a Dominican monk, and we know that in all that relates to the table, and especially the food of fast-days, monks are the authorities. The old buccaneers-from whom this dish was named-having no ovens, cooked their turtle in a trench covered with lighted charcoal, and this mode of cooking was said to be preferable. But in whatever manner dressed, all agree that the flesh of the turtle is an excellent and palatable food.

Green turtle soup is now manufactured in America and the West Indies. A manufactory at Key West, Florida, puts up in air-tight cans for exportation 200,000 lbs. yearly, and employs ro vessels and 60 men in collecting the turtle. It is sent to England and Cuba chiefly. At Jamaica some factories are also doing a good business in a preparation worthy of the gastronomic patronage of an aldermanic banquet, so rich is it in green fat and calipee, calipash, and those delicate gelatinous morsels appertaining to the fins. A steady supply of 


\section{The Commercial Products of the Sea.}

turtle is obtained monthly through the West India and Pacific steamers from Colon, besides those brought from the Caymanas. $5484 \mathrm{lbs}$. of prepared turtle, valued at $£ 356$, were shipped from Jamaica in 1874 .

Jamaica is the principal mart in the West Indies to which the turtle are brought from the coasts of the Gulf of Mexico, from Trinidad to Vera Cruz, principally from Honduras and the Tortugas. From Jamaica they are sent to England and the United States.

Although all the varieties of the edible turtle are palatable, yet they are distinguished by the localities from whence they are obtained, and some are preferred to others. Those of the Bay of Honduras are most esteemed in England. Of the Cape Verd Islands, those of St. Vincent are considered the best. Dampier tells us that they are not so large as those of the American islands. The flesh is white and intermixed with the green fat, which is firm and of good flavour.

But it is not only the flesh that is useful; the fat, exposed to the sun, is converted into oil. When fresh, it is good for frying and for other culinary uses, and when it becomes rancid, as it is very fluid and penetrating, it serves to oil leather, to burn, and to lubricate machinery. It is not rare to obtain $100 \mathrm{lbs}$. of oil from a single turtle. Oil is obtained from two species of turtle very abundant in the river Orinoco-Peltocephalus Tracaya, and another. The gigantic luth is famous on account of its valuable oil.

The eggs of most of the species of sea-tortoises or turtle are excellent, being both nutritious and agreeable to the taste. They have no firm shell, and the white or albuminous portion does not harden on cooking. A native of Brazil will consume as many as 20 or 30 at a meal, and a European will eat a dozen for breakfast. They make an 


\section{Tortoiseshell and the Turtle Fisheries. 369}

excellent omelet. The Indians frequently eat them raw, mixed with their cassava flour. A large quantity of rich oil is made from the immense deposits of turtle eggs on the banks of the Orinoco and Amazon; each turtle lays from IOO to 200 eggs. Several thousand persons are occupied on the banks of these rivers preparing this mantega or turtle oil as a local article of commerce. 


\section{CHAPTER II.}

MOTHER-OF-PEARL AND ITS USES.

Composition of nacreous shells-Their extensive employment in art and manufacture-Explanation of prismatic colours-Varieties of mother-ofpearl shells entering into commerce-Purposes to which they are applied -Statistics of imports-Diving for the shells in the Pacific-Pearl fishery of Western Australia-Papier-mâche work-Other nacreous and iridescent shells used-The ear-shells or Haliotids.

AMONG the products obtained from the sea which are used by the artist and art-manufacturer, mother-of-pearl and other nacreous and iridescent shells form important articles of commerce, to which we will now direct attention.

The mother-of-pearl shells which our manufacturers transform into so many articles of ornament and utility, are those of the large oysters, obtained in many different parts of the world, chiefly the shells of Meleagrina margaritifera.

Shells are composed of carbonate of lime, with a small proportion of animal matter. The source of this lime is to be looked for in their food. The texture of shells is various and characteristic. Some when broken present a dull lustre like marble or china, and are termed porcelaneous; others are pearly or nacreous; some have a fibrous structure; some are horny, and others are glassy and transparent. 


\section{Mother-of-Pearl and its $U^{\prime}$ ses.}

The nacreous shells are formed by alternate layers of very thin membrane and carbonate of lime; but this alone does not give the pearly lustre, which appears to depend on minute undulations in the layers. The fibrous shells consist of successive layers of prismatic cells containing translucent carbonate of lime. The exquisitely fine series of furrows upon the surface sheds a brilliant rèflection of colours according to the angle at which the light falls upon them.

The concrete composition of mother-of-pearl, being deposited in annual layers, is excessively hard, and requires good tools to work it; sulphuric and other powerful acids are brought to the aid of the circular saw, the drill, and the file, and calcined sulphate of iron is used to give a polish to the objects. The Japanese and Chinese have evidently means and processes for working this material which are unknown to us, for they give a finish and a polish to their pearlwork carvings and inlayings, which the skilful artists of the western world admire and envy.

Besides its use for buttons, studs, the handles of knives, fans, book-covers, card-cases, and other fancy articles, mother-of-pearl is also employed by cabinet-makers, pianoforte manufacturers, papier-mâché workers, and others, for inlaying. The range of articles made of this substance is very extensive; pen-holders, carved brooches, earrings, buckles, sleeve-links, little boxes, and hundreds of others, might be enumerated.

The greatly increased use of this material in various branches of manufacture, particularly those of an ornamental character, has more than doubled the price of the shells. From 4000 to 5000 persons used to be engaged in the manufacture at Birmingham, but the number has been greatly reduced in consequence of other countries com- 


\section{The Commercial Products of the Sea.}

peting with us in the manufacture. France now works up about I 500 tons of mother-of-pearl annually, while North America and Austria also compete with us. We import from I 500 to 2000 tons of mother-of-pearl annually, worth about £100,000.

The quantity of mother-of-pearl and other nacreous shells imported into France is thus given in the French official returns :Average Annual Imports.

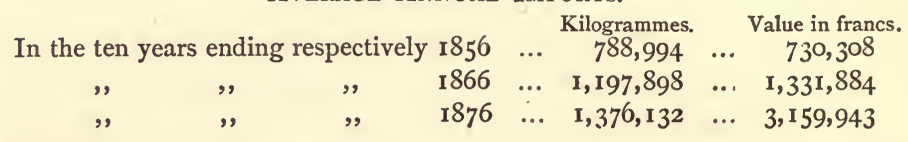

Sea-ear shells (Haliotis) are also now imported into France to the extent of 134,550 kilogrammes a year.

Button-making is one, of the largest uses to which mother-of-pearl is turned. The blanks are cut out of the shell with the annular or crown-saw fixed upon a lathe mandril. They are split into two or more sections, according to the thickness of the button required. They are then ground down and cleaned, turned into a pattern, and afterwards "fancied," or an ornament is worked on the face. Next, the holes are drilled by which the button has to be attached with thread to the garment, and lastly they are polished. They are finally sorted and mounted on cards of a gross each, which sell at from $1 s .6 d$. to $8 s$. There are some firms in Birmingham which turn out 500,000 gross annually. Pearl buttons are made of all sizes, from the Brobdignag ones as big as half a crown, for coats, costing $2 s$. or $3 s$. each, to the very tiny ones used for mere ornament.

This beautiful material has been as valuable to science, by supplying confirmatory evidence of the truth of Newton's views respecting the origin of colour, as it has been 
to the manufacturer, in furnishing him with an elegant material for the formation of ornamental articles of various kinds.

Mother-of-pearl is the interior lamina or scales of the shell of various mollusca living in the Indian seas. The true pearl oysters, as they are called, exhibit the beautifully variegated colours of mother-of-pearl; but it is a much larger species called the Meleagrina margaritifera, which affords the most exquisite specimens. That many shells have a certain degree of resemblance on their inner surfaces to this substance we have every-day proof ; for, if we inspect the interior of a common oyster shell, we shall frequently find that it exhibits that rich play of tints which constitutes the beauty of mother-of-pearl ; and, with respect to mussels, Reaumur remarked, in the early part of the last century, that those caught off the coast of Provence had the interior of their shells variously tinted, one portion of each shell being pearl-like in its appearance.

No one can avoid being struck with the diversity and delicacy of the ever-varying tints of colour of this beautiful substance; but there appears to have been no attempt made to discover the cause of the production until Sir David Brewster took up the subject, which he did with great success, and added another to the long list of services which he has rendered to optical science.

Sir D. Brewster says: "If we take a plate of regularly formed mother-of-pearl, having its two opposite surfaces ground flat (but not polished), and if, with the eye placed close to the plate, we view in it by reflection a candle standing at the distance of a few feet, we shall observe a dull and imperfect image free from colour. This image is formed on the ordinary principles of reflection, and is faint and undefined, owing to the imperfect reflecting power of 


\section{The Commercial Products of the Sea.}

the ground surface. On one side of this imperfect image will be seen a brighter image, glowing with the prismatic colours. On the outside of the prismatic image will be observed a mass of coloured light, nearly at the same distance beyond the prismatic image that the latter is from the common image. These three images are always in the same right line, but their distances from one another vary according to the direction in which they are viewed."

Now, it was in making certain observations on the distances of these images from one another that Sir David Brewster lighted upon the cause of them. He had occasion to fix a piece of mother-of-pearl to a goniometer (an instrument for measuring angles), by a cement of rosin and beeswax. Upon removing it from the cement when in a hard state, by insinuating the edge of a knife and making it spring off, the plate of mother-of-pearl left a clean impression of its own surface; and he was surprised to observe that the cement had actually received the property of producing the colours which were exhibited by the mother-of-pearl. This unexpected phenomenon was at first attributed by him, and by several gentlemen who saw the experiment, to a very thin film of mother-of-pearl detached from the plate and left upon the cement; but subsequent experiments convinced him that this was a mistaken opinion, and that the mother-of-pearl really communicated to the cement the properties which it possessed.

This circumstance sufficiently proved to Sir D. Brewster that the cause, whatever it might be, of the colours of mother-of-pearl resided on the surface, and did not depend upon the chemical nature of the substance. In order, therefore, to discover what was the configuration of the surface, he applied a microscope with high magnifying 
powers to the surface, when he perceived a grooved structure, closely resembling, as he says, "the delicate texture of the skin at the top of an infant's finger, or the minute corrugations which are often seen on surfaces covered with varnish or oil paint." When the mother-of-pearl was regular in its structure the grooves were all parallel, and the reflected images of a candle appeared all in one straight line; but when they were tortuous or curved, the images of a candle were not in a straight line.

Here, then, was proof that the colours were produced by the effect of the grooves on the light reflected from the surface ; for on applying the microscope to the wax, which exhibited the same colours, a similar assemblage of grooves was observed. A consideration of Sir Isaac Newton's theory of the causes of the colours of thin bodies (which is not of a nature to be introduced here) has made it demonstrable that the series of grooves breaks up a beam of light which falls upon them, into a number of separate parts, each of which is reflected on the eye from the bottom and side of the little grooves, and assumes a particular colour according to the angle at which it is reflected.

This singularly beautiful appearance can be transferred to balsam of Tolu, or to gum-arabic, by allowing the thin film to be pressed and to solidify between two pieces of mother-of-pearl ; or it may be communicated to a clean surface of lead, or to the fusible metal resulting from the compound of mercury and bismuth by hammering.

With respect to the fineness and number of these grooves, different specimens of shell give very different results. Sometimes a magnifying power of six or eight times will render them imperceptible, while in other instances 2000 grooves have been counted in the space of an inch, and in others, again, the number was wholly incal- 


\section{The Commercial Products of the Sea.}

culable. What is very remarkable is that grinding will not obliterate these grooves. It might be supposed that as the grooves must be separated from one another by slight ridges, these ridges might be worn away in the process of grinding. But as the ridges wear down, so do the grooves also ; so that, however thin the film may be rendered by grinding, the grooves and the colours resulting from them are still developed. If the surface has any scratches or dents, the bottoms and sides of the scratches are grooved, just as if the surface had been level.

If we view a candle through a thin film of mother-ofpearl, or of gum or balsam which has received the grooved impression, coloured images of the candle will be seen nearly as distinctly as when the light is reflected from its surface.

If a scientific statement be true, there are generally means for proving its applicability in more circumstances than one. Consequently, if the colours of mother-of-pearl are produced by grooves on its surface, any mechanical contrivance by which similar grooves may be produced on any substance ought to give similar results. This has been strikingly confirmed by Mr. Barton, of the Royal Mint. This gentleman has constructed an engine by which he can engrave on the surface of steel and other metals lines so exquisitely minute that from 2000 to 10,000 are included in a single inch. These surfaces, when viewed by daylight, present but few appearances of colour; but when the light of the sun or of gas flames falls upon them, an extremely brilliant display of colours is the result; every gradation of tint is exhibited, and a change is produced by every motion of the object or of the source of illumination.

There are six or eight leading varieties of mother-ofpearl shells entering into commerce. 


\section{Mother-of-Pearl and its Uses.}

I. Those from the Arru Islands, which are the most valuable. This group, situate at the south-west of New Guinea, extends about 100 miles from north to south. From I 30 to 150 tons are obtained from this locality annually. Pearl oysters are abundant on parts of the coasts of New Caledonia, but generally at too great depths: to be obtainable. There are three sorts, which are classified in commerce as bastard, black-bordered, and silvery white, the last being the most esteemed.

2. The fishery next in importance is that from Sulu to New Guinea, etc. All the extensive range from Cape Unsing, passing by the Tawi-Tawi Islands and Sulu as far as Baselan, is one vast continuous bed of pearl oysters. The fishing is partly carried on by the Malays and partly by the Chinese, and from 2500 to $3000 \mathrm{cwts}$. are sold there annually. The Sulu pearls have from time immemorial been celebrated and praised as the most valuable of any in the world. The shells are distinguished by the yellow colour of the border and back, which renders them unfit for ornamental purposes, but they are largely used by the Sheffield cutlers. Of the Sulu Archipelago we know comparatively little. The people of Sulu and the Lanuns of Mindanao are the most daring habitual pirates of the Malayan seas. The principal articles of commerce of the Sulu and neighbouring islands are the produce of the fisheries, namely, pearls, mother-of-pearl shells, tortoiseshell, etc.

3. The so-called Bombay shells of commerce come in reality from the Persian Gulf fishery, where the search for pearls is vigorously and successfully prosecuted. Most of the shells from this quarter are small, and generally dark about the edges. They, however, realize more than the Panama and Tahiti shells. The imports range from 


\section{The Commercial Products of the Sea.}

about 3000 to 5000 cwts. per annum. They are chiefly used in Birmingham for buttons, counters, and inlaying purposes.

4. The shells from the Red Sea fishery bear the name of "Egyptian," as they are sent to Alexandria. For a long time the bulk of these shells were forwarded viâ Trieste to Vienna, affording employment to a large number of artisans, who worked for the American market, and thus displaced about, 50 per cent. of the British-made goods. But after the great rise in the price of mother-of-pearl shells, the larger proportion of the Red Sea shells was again sent for some years to London and Liverpool. About I 2,000 cwts. are shipped annually from Alexandria; but we only get at present about half this quantity.

5. Panama shells from the Gulf of Panama, about the Pearl Islands, are now obtained in large quantities. The shells from the island of St. Joseph (one of this group) are said to be the largest, purest, and finest in the bay. After I 855 the trade began to be conducted on an important scale, five or six vessels taking cargoes of 100 to 250 tons each for Great Britain; 800 to 1000 tons is about the average annual shipment from this quarter.

According to their growth, the mother-of-pearl shells imported vary in size from about the palm of the hand to that of the crown of a hat. The smallest are the South American, weighing nearly half a pound the shell (the single valve); the Bombay and Egyptian weigh about threequarters of a pound; the South Sea black, one pound; and the Singapore and Manila as much as one and a quarter pound each. Their value greatly depends upon quality, for they arrive in bulk without any attention being paid to sorting, and keeping separate, the dead and grubby or worm-eaten shells, of which there is always a great 


\section{Mother-of-Pearl and its Uses.}

proportion among the larger shells. The medium and small sorts, being the cleanest, bring higher rates in comparison with the larger kinds. They should always be of a bold, fine, good, clear white colour and substance, and not broken.

Fashion, in this as in other manufactures, has much to do with the price and supply of the raw material. About I 5 years ago the black-edged shell, often termed "smoked pearl," was in much demand for the large dark buttons worn on ladies' paletots, gentlemen's waistcoats, shooting coats, etc., but these have gone somewhat out of fashion. Other shells of a deep, dark, iridescent hue were imported largely some 30 or 40 years ago, and, having only a nominal value, were buried in piles in the earth at Birmingham; a demand having again sprung up for them, many instances have occurred in which they have been dug up and used. An anecdote was recently told me by a large wholesale shell-merchant in London, of a workman in Birmingham having volunteered to dig up his neighbour's yard or garden free. The offer being declined, the man persisted, agreeing to give $£_{5}$ if he might be allowed to do it, and cart away the rubbish. Consent was at last obtained, and the digger cleared $£ 20$ by the pearl shells he thus obtained and sold. My informant also told me that the Town Hall of Birmingham is built on such mounds of these shells that it would almost pay, at present prices, to pull it down and rebuild it for the sake of the shells that could be thus obtained.

The use of pearl for hafting cutlery, the handles of dessert knives and forks, fruit-knives, etc., is not so general as it used to be; not many years ago 100 tons were employed annually in Sheffield for this purpose. The only nacreous shells possessing sufficient thickness for Sheffield 


\section{The Commercial Products of the Sea.}

purposes are received from Manila and Singapore, and of late years from Western Australia. So variable is the supply and demand, that this description of pearl shell has been sold within the last 50 years at almost all rates, between $£ 60$ and $£ 600$ per ton. The "scales" (as the two flat pieces are termed which are riveted to the central plate of the haft of the knife) have to be ground down on stones, singly and by hand, to a level surface and the required thickness. This tedious process aids in making shell a costly covering for cutlery, and as the substance is both hard and brittle, when the handles are fluted or carved, the price is of course still further enhanced.

The numerous visitors to the Paris International Exhibition of 1867 could not fail to be struck with the mosaic pictures in mother-of-pearl, shown in the Siamese Court, representing the idol Buddha, the perfection and originality of which excited the envy of amateurs. The King of Siam, when informed of this fact, commanded the artists of his palace to execute two other mosaics; and in order to render them more agreeable to European taste, they were made to represent the Saviour, and were presented at the close of the Exhibition to the Empress Eugènie, in order that they might adorn some Catholic chapel.

The commerce in mother-of-pearl is extensive in Cochin China, where this substance is much employed for inlaying choice articles of furniture. It is obtained mostly in the Bay of Tirwar. Some of the other French colonies in India supply small quantities of mother-ofpearl. The shells of the true pearl oysters of Ceylon (Avicula margaritifera) are too thin to be of use in manufactures for their nacre, although importations have from time to time been made here, in the hope of utilizing 
some of the mounds of shells which have accumulated on the shores of the island from time to time after the periodical fisheries for pearls.

In inlaying with pearl shell the artist traces the stems and leaves of the flowers with a camel's-hair pencil, dipped in a size made of varnish and turpentine; upon this he lays gold-leaf, which adheres where there is size, and the superfluous gold is carefully brushed off with a piece of silk. The flowers and leaves are then painted in colours, and, when dry, the picture and surface of the article is covered with a coat of refined white varnish.

The second method of inlaying consists in sketching the ornament or design with some kind of varnish not acted upon by acid, upon the piece of the shell ground and polished upon revolving wheels, as in the other case, and then etching away the surrounding unpolished portions by means of an acid. This process possesses several advantages, one of which is that it is much cheaper than where the design is cut out by hand.

But little taste has been exhibited in the decoration of English papier-mâché goods, and they have been for the most part vulgar and tawdry in design and execution. Even the Japanese, with all their good taste and artistic skill, have lately imitated closely our style of papier-mâché work, without any of that refinement and originality of design of which they are so capable.

The survey thus taken of the various uses of pearl shells will serve to show how extensive is the range of applications to which they are put, and how important and valuable the commerce in an article of this kind may become. Every day develops some new use for mother-ofpearl, and although the material is not one on which any great artistic skill can be displayed, still trade ingenuity 
382 The Commercial Products of the Sea.

and inventive genius are being constantly devoted to its utilization.

We may now turn to a few details of the commerce in pearl shells. It was only in 1853 that mother-of-pearl shells were deemed of sufficient importance to appear in the Board of Trade returns. The imports from that period to 1870 were as follows. No official returns have, however, been published since :-

\begin{tabular}{|c|c|c|c|c|c|c|}
\hline 185 & & . & $\begin{array}{l}\text { Cwts. } \\
15,480\end{array}$ & $\ldots$ & $\ldots$ & Value. \\
\hline I854 & $\begin{array}{l}\cdots \\
\cdots\end{array}$ & $\cdots$ & 36,644 & $\cdots$ & $\ldots$ & $£ 88,305$ \\
\hline 355 & $\ldots$ & $\ldots$ & 20,120 & ... & $\ldots$ & 34,634 \\
\hline 1856 & ... & $\ldots$ & 42,032 & $\ldots$ & $\ldots$ & 76,544 \\
\hline 1857 & $\ldots$ & $\ldots$ & 34,324 & $\ldots$ & $\ldots$ & 57,8 r9 \\
\hline 1 $85^{8}$ & $\ldots$ & $\ldots$ & 25,108 & $\ldots$ & $\ldots$ & 60,448 \\
\hline 1859 & $\ldots$ & $\ldots$ & 40,003 & $\ldots$ & $\ldots$ & 67,859 \\
\hline 1860 & $\ldots$ & $\ldots$ & 30,054 & $\ldots$ & $\ldots$ & 59,707 \\
\hline 1862 & $\cdots$ & $\ldots$ & 25,442 & $\ldots$ & ... & 38,677 \\
\hline 1863 & $\cdots$ & $\ldots$ & 20,322 & ... & $\ldots$ & 35,316 \\
\hline 1864 & $\cdots$ & $\ldots$ & 19,415 & $\ldots$ & $\ldots$ & 30,416 \\
\hline 1865 & $\ldots$ & $\ldots$ & 27,262 & $\therefore$ & $\ldots$ & 42,663 \\
\hline I866 & $\cdots$ & $\ldots$ & 24,022 & $\ldots$ & $\ldots$ & 41,746 \\
\hline 1867 & $\ldots$ & $\ldots$ & 36,175 & $\ldots$ & $\ldots$ & 70,426 \\
\hline 1868 & $\ldots$ & $\ldots$ & 32,002 & $\ldots$ & $\ldots$ & 64,869 \\
\hline 1869 & $\cdots$ & $\ldots$ & 37,662 & $\ldots$ & $\ldots$ & 94,015 \\
\hline 1870 & $\cdots$ & $\ldots$ & 26,197 & $\ldots$ & $\ldots$ & 76,489 \\
\hline
\end{tabular}

In the time of the Jesuit missionaries the pearl fishery was actively carried on, and produced great wealth to the people of Lower California. The value of the shells is sufficient to pay the expense of the fishing, leaving the pearls which may be obtained as clear gain. The best pearl-bearing shells are found at between 14 and I 8 fathoms, but locality has, apparently, much influence both on the shell and the pearl, not only in quantity but also in quality. At some of the islands, the banks, even in shallow water, are quite choice in their yield, while at others, as in the Isle de Puercos, the shells are tortuous 
and blistered, with dark spots, and but lightly esteemed in the markets of Europe.

Not only are they found at the islands, but all along the shores of the mainland, and it is generally believed that a series of deposits exists from the Gulf of Darien to that of California. In the waters of the latter place, and along the shores of Central Mexico and Costa Rica, fishers of shell have for a long time enjoyed a profitable employment. Thirteen or fourteen tons of pearl shell were shipped from Guayaquil in $187 \mathrm{I}$.

The upper portions of the cathedral and some of the churches of Panama are studded with mother-of-pearl shells, which give them a quaint and striking aspect under the reflection of the sun's rays. In many of the houses at Manila, also, the outer side of the verandah is composed of coarse and dark-coloured mother-of-pearl shells and paper oyster shells set in a wooden framework of small squares, forming windows which move on slides. Although the light admitted through this sort of window is much inferior to what glass would give, the material has the advantage of being strong, and is not very liable to be damaged by the severe weather to which it is occasionally exposed during some months of the year.

From the province of Chiriqui several shipments have at sundry times been made by merchants of Panama, of shells obtained from deposits in that neighbourhood, and boatmen who bring the ordinary edible oyster to market there assert that banks of the pearl-bearing mollusc, at not very distant intervals, abound in every direction on the coast. The small shells, of which many thousands are taken out and cast away, are of no value; but the full-grown and well-matured shells, rich in their iridescent nacreous beauties, are in high estimation and of 


\section{The Commercial Products of the Sea.}

superior market worth. The fishery has not been prosecuted with that vigour it might be, in consequence of the fear entertained of sharks, sword-fish, alligators, and other ravenous monsters which infest the shores of the coasts, but which are so comparatively rare about the islands as not to create great alarm among the divers.

Several attempts have been made within the last quarter of a century, by companies and individuals, to employ diving-bells and apparatus, but in every instance some fault or difficulty has occurred to discourage the efforts. Besides

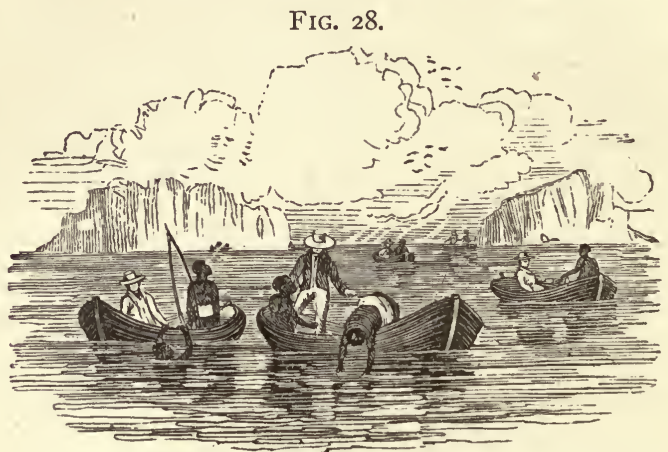

Diving for pearl shells at Panama.

the obstructions caused by the irregularities of the sea bottom to a complete adjustment of the machines, much inconvenience was experienced in moving about from bank to bank, it being necessary on every occasion to unship the derricks and other fixtures, so as to enable the vessel to be sailed from one fishing ground to another. The diving armour met with no favour among the natives, who could not be induced to adopt it.

The fishery for mother-of-pearl shells has now been carried on upon the California coast in the vicinity of Santa Barbara for some IO or 12 years past, and is also 
prosecuted on the southern coast. Immense quantities of pearl shells are at present used in the United States in the manufacture of buttons, card-cases, portmonnaies, and other fancy articles. Many of the islands about the California coast are literally covered with the finest shells for this purpose found in the world. On the shores of Anacapa, off Santa Cruz, a few men easily load a schooner.

Shells for ornament are equally appreciated by the aboriginal races, and some of their modes of application for decorative purposes are effective and curious. Many of the Dyaks of Borneo wear a large polished pearl shell appended in front to their corslet, and their shields are ornamented with these shells. In the ethnological room of the British Museum many examples of the uses of pearl shell by the Pacific Islanders may be seen. There is especially worthy of notice an elaborate corslet from Polynesia, studded with mother-of-pearl shells, and beautifully ornamented with a kind of deep swinging fringe made of minute pieces of pearl shell, skilfully cut and threaded together, evidencing great skill and ingenuity in the absence of European tools and appliances. The Pacific Islander plunges beneath the waves to seek the joints of his simple necklace, or to supply his brothers of the Western World with highly prized material for more elaborate ornaments. The glittering ear-shell and mother-of-pearl furnish the New Zealanders and Fijians with attractive fish-hooks to ensnare their prey.

The export of mother-of-pearl from Manila was, in 1874 , I035 piculs of I $33 \mathrm{lbs}$. each; and in I875, I 378 piculs. Bold white shells from Manila realized at the London sales in January, I 876, £I 2 to $£ \mathrm{I} 25 \mathrm{~s}$.; bold and medium kinds, $£$ I I $7 s$. $6 d$.; chicken, $£ 7$ 5s. to $£ 8$ i $7 s$. $6 d$; defective wormy, $£ 62 s$. $6 d$. to $£ 7$ I $7 s .6 d$. 


\section{The Commercial Products of the Sea.}

The author of "Rovings in the Pacific" thus speaks of the pearl divers in the South Seas:- "It is a curious sight to watch the divers: with scarcely a movement they will dart to the bottom like an arrow, examine beneath every protruding rock, and on continuing their investigations, by a simple movement of the arm will propel themselves horizontally through the water, and this at the depth of seven and eight fathoms. I timed several by the watch; and the longest period I knew any of them to keep beneath the water was a minute and a quarter, and there were only two who accomplished this feat. One of them, from his great skill, was nicknamed by his companions the 'Ofai' (stone). Rather less than a minute was the usual duration. In fine weather they can see the shells, when if the water is deep, they dive at an angle for them ; and as the shells adhere firmly to the coral by strong beards, it requires no little force to detach them. I was astonished on one occasion at witnessing a diver, after one or two ineffectual attempts to tear away a large oyster, sink his legs beneath him, and getting a purchase with his feet against the coral, use both his hands and fairly drag it off. When they dive in very deep water, they complain of pains in the ears, and they sometimes come up with their noses bleeding; but it is rarely that you can get them to attempt such diving, as, let the shells be ever so abundant, they will come up and swear there are none : the exertion from the great pressure is too painfully distressing. It has frequently happened, after a set of worn-out divers have sworn that no shells could be obtained, that a fresh set has come and procured from 50 to 60 tons without difficulty."

The diving for pearl shells is one of the principal occupations among the natives of the Oceanic Islands in the Pacific. A diver will collect from 20 to 40 shells per day 
according to the state of the sea. The finest are met with on sandy bottoms and in the currents. The fishery is extensively prosecuted in the archipelago of the islands of Pomotou and Gambier, and the shells are chiefly taken to Tahiti, where they form a principal article of export, averaging about 1000 tons a year. The shells from the Pacific are fine, thick, and of a silvery white. The fishery about the Gambier Islands is carried on from January to April. One of the neighbouring islands-Crescent Islandfurnishes a smaller oyster of straw-coloured hue.

The export of mother-of-pearl shells from Tahiti varies greatly. In I 845324 tons were shipped. It then dropped to an average of about 200 tons up to 1852 . In 1853 as much as 600 tons were shipped. The exports then fell off to almost none, but in I868, owing to an increased demand, rose to 420 tons. In 1873 the shipments were 328 tons, and in 18744 IO tons, valued at $£ 20,530$. An export duty of $£^{\mathrm{I}}$ I $2 s$. per ton has been imposed since January I, I 875 , in order to check the taking of undersized shells of comparatively small value from the pearl oyster banks.

Besides the above shells, 296 tons of what are called Maara shells (Turbo margaritaceus), valued at $£ \mathrm{I} 480$, were shipped from Tahiti in 1874 .

Mother-of-pearl shell to the value of $£ 600$, and pearls valued at $£ 1600$, were shipped from the Navigator's Islands in 1858 .

In the Paomotus Islands, mother-of-pearl shell was in I873 only worth twopence to threepence per pound; in the following year the price advanced to sixpence per pound.

The pearl oyster of the Pacific is an inhabitant of the interior lagoons of certain of the great coral atolls. The necessities of its existence appear to be clean, grow- 


\section{The Commercial Products of the Sea.}

ing coral, to which to attach itself, free from sand or drift, and a considerable influx and outflow of the sea at the rise and fall of the tide. That they are not absolutely confined to lagoons, but exist also in great quantity under the tremendous breakers which beat upon the outer reefs (as also, probably, at greater depths in the sea beyond them), is a fact not generally known, but is nevertheless true. As a proof of this, there are to be found, chiefly on the windward side of all coral reefs enclosing lagoons (and especially at certain seasons of the year), incredible numbers of microscopic pearl oysters, and others of larger size, up to the diameter of a shilling, tossed about in the foam of the breakers, and travelling with the flood tide over the reef towards the calm waters of the lagoon. These have been spawned in the deep sea, or in the coral caves under the foaming surf, which thunders on the outer reef, and seek by some instinct of their nature to make their own way into the placid waters enclosed within that stony barrier. The oysters which are spawned within the lagoon are formed in congeries attached to the parent shells, or clustered in vast numbers, fastened to one another, in the holes of the rocks. The shell comes to maturity in about seven years, at which time its average weight is one pound, exclusive of the fish contained in it. The usual size is about that of a soup-plate, or Io inches in diameter, although in rare instances they arrive at as much as I8. After this the creature perishes, detaches itself from the rock, opens to close no more, the animal decays, and the shell, becoming coated with coral and other stony parasites within and without, loses all value.

The pearl oyster is gregarious. Wheresoever one is met with, there are of a surety vast numbers somewhere in the immediate vicinity. They are found in coral caverns, hang- 


\section{Mother-of-Pearl and its Uses.}

ing from the roof, linked together after the manner of a chain, or clustered in large piles, firmly attached to one another. This attachment is only temporary. It has been generally believed that the pearl oyster is a fixture, and certainly the appearance of the cable by which it binds itself to the rock would warrant that supposition. This attachment has the look of a large tassel, consisting of an infinite number of slender filaments, each about the thickness of a packthread. It springs from the body of the mollusc, and passes through an orifice between the shells, immediately next the hinge. During life its colour is iridescent, changing from a dark green to a golden bronze, exhibiting while in motion various prismatic hues. It fastens itself to the rugged rocks with so determined a hold as frequently to require the utmost strength of a powerful man to tear it from them. Under these circumstances it seems incredible that the mollusc should move from place to place. But to borrow the words of Galileo, "Nevertheless, it does move;" and under the influences of certain causes, these bivalves are in the habit of migrating en masse, not for any great distance, it is true, yet from one coral shelf to others in the immediate neighbourhood. As concerns the reason of their exodus, it may possibly be an alteration in the temperature of the water, caused by a change of weather, or a scarcity of the animalculæ upon which the oyster feeds.

The presence of drift-sand is obnoxious to its comfort; consequently, in the neighbourhood of banks and crags composed of that kind of débris it will not live. In lagoons which have no tideway it is not found, and if introduced there, perishes. The experiment has frequently been tried, and its failure seems traceable to the following cause:-Wheresoever sea-water becomes 


\section{The Commercial Products of the Sea.}

stagnant in the lagoons of the Pacific, there makes its appearance in great numbers a hideous reptile, resembling a centipede, which is found from the smallest conceivable size up to a foot long. These enter and devour the oyster. They may have other enemies, but this one is the most notable.

Under favourable conditions, the life of the pearl oyster would seem to be one of uninterrupted ease and passive enjoyment. Himself a creature most gloriously beautiful, his existence is passed among forms of the most surpassing loveliness, bathed in the cool, bright, unpolluted waters of the main. There he adheres to the side of some caverned cliff, covered with marine vegetation, spreading out his ample beard .(of which the dazzling colours, when viewed in the light of the refracted sunshine, beaming through the limpid element in which he dwells, are like the tints of the opal), and sweeping around him his snaky tongue, he feeds daintily and waxes fat, devoting the surplus of his nacreous secretion to the production of a precious gem.

It may be as well to mention here that pearls are, under certain conditions, liable to a form of decay, or loss of brilliancy, which impairs their value. A good preservative against such a contingency is to keep them in magnesia.

Surely, his lines are cast in pleasant places, and his existence might be one of unalloyed happiness ; nevertheless, he has his afflictions. Almost all well-grown pearl oysters are infested with parasites, in the shape of a scarlet lobster, about the size of a shrimp. This pestilent intruder introduces himself into the shell in conjunction, as it appears, with the partner of his joys, and making themselves a bed under the fat, soft body of their victim, resisting all attempts to dislodge them, rear their interesting progeny, and cause no end of pain and annoyance. 
The true cause of the production of pearls is supposed by many to be a disease in the animal, for the following reasons:-In the first place, wheresoever a pearl fishery is found of which the oysters grow to great size, with a clean, smooth outer surface, free from knots, humps, worm holes, or other blemishes-in fact, presenting every appearance of healthy and uninterrupted development (which is particularly noticeable in lagoons where the shells are wide apart)—there will the pearls be extremely scarce; so much so that it would not pay to prosecute such a fishery for the profit to be derived from the pearls alone, although the shell is proportionately more valuable. On the other hand, where shells are closely crowded together, deformed by pressure, abnormally thickened about the base, having laminæ of which their outside is composed forced at their edges into an unnatural contact, so as to induce a belief that their growth had been stunted, as likewise being studded with warts and knots of a scabby appearance, being, moreover, honeycombed with small worm holes which penetrate more or less deeply into the nacre-there will pearls most exceedingly abound. It is not uncommon for as many as 100 pearls to be found in such a shell, though the presumption is that where they exist in such great numbers, very few, and frequently none whatever, will possess any market value.

But of the presence of the conditions necessary to the production of a pearl inside of an oyster there is one very significant and certain sign, the faculty of detecting which can only be acquired by practice. While the animal is alive, the two flat surfaces which appear at the back of the hinge present very beautiful prismatic colours; the cable which attaches it to the rock is in like manner remarkable. When the shell contains pearls, the prevailing colour of these 
portions is, while in vigorous life (as when just removed from the water), a certain shade of bronze, brilliant but evanescent, which is not easy to describe, but very easy to be recognized by the experienced fisher. By this means a man well used to the work will, with great certainty, pick out from a boat-load of living oysters at least 75 per cent. of those which contain pearls.

In the Pacific, all oysters are opened with a knife, which, if carefully performed, is the best plan. The best instrument for this purpose is a common table-knife of good steel, ground thin until the blade is flexible, and fitted into a stout handle. A skilful operator will open a ton of shells in an ordinary day's work, and not miss the pearls if there be any. It cannot be done rapidly without frequently cutting the hands (sometimes seriously), as the edges are as sharp as glass. But men working for themselves, with a prospect of considerable gain, do not mind such accidents. The excitement is like that of gold-mining. White men, well up to this work, will never (if they can avoid it) allow valuable shells to be opened by any other hands than their own, as the natives are sure to steal them if they have an opportunity.

When the shells are landed, the usual custom of the fisherman is to sort them into two piles, such as he supposes to contain pearls to be opened by himself, the rest by the natives. The empty shells ought to be at once placed under a shed, to protect them from the rays of the sun, and so preserve their beautiful colours. In hard times it is usual for men to eat the animal which comes out of the pearl shell, cooking the residue in an oven of stones, and then drying them in the sun; but they are coarse, rank, and disagreeable as food, though perfectly wholesome. The pearls are usually lodged in the rong muscle of the 


\section{Mother-of-Pearl and its Uses.}

fish, out of which the cable, as it is called, springs. This is about the thickness of that part of a man's hand which is next to the thumb. The flesh being semi-transparent, the pearls are at once seen from their brightness, which refracts the light. Their presence is easily detected. Sometimes they exist in great numbers in one mollusc, but in such cases they are generally small and ill-formed. There are other pearls which are found loose in the shell, and these are always of very fine quality, perfectly round, and very often large. If the shell be carelessly opened, such a pearl, if it be in it, invariably falls out, being carried away by the beard in the agony of the mollusc when divided by the knife, and is thus almost sure to be ejected from the shell. Thus it has been that upon the Pacific fisheries by far the greater number of the most valuable of these gems have been irretrievably lost, for the reason that the natives, howsoever experienced, never look for a pearl elsewhere than in the muscle of the fish. They squat down on the sand, place the shell between their legs, stick in the knife, and wrench it open; and if there be one of these beard pearls (which are often worth a hundred of the others), down it slips into the sand, and is never seen; but as a rule not more than one oyster out of a thousand contains a pearl upon the beard.

Fine, calm weather is most favourable to pearl-fishing, but not indispensable, as the amphibious natives of some groups seek the shell by swimming with their heads below the surface of the water, and having discovered it, inhale a good draught of air, and then go down and fetch up as many as they can readily lay hold of. Polynesian divers do not use any stones to sink them, or any apparatus to close the nostrils, as do the Singalese. They will stay under water about a minute or two, sometimes longer, and 


\section{The Commercial Products of the Sea.}

can bring up shell (if put to it) out of 20 fathoms. It requires some extra inducement to get them down that depth, and of course they cannot stick long at it; but Penrhyn islanders, Paomotans, or Rapa men, can do it if they like. Where shells are found at that depth, they are of enormous size, as much as 18 inches in diameter, so that a pair, when opened out by the hinge, will measure a yard across. This work of pearl-diving is very hard, and the heat of the sun, aggravated by its radiation from the still water of the lagoons, is frightful. The divers rub their bodies with oil, otherwise their bronzed skin would peel off in huge blisters.

On many islands women are more skilful at this work than men, as, being accustomed from early life to supply cockles and clams to the lords of the creation, they are the better divers. They are paid in cloth-i.e., cotton printtobacco, hardware, and ornaments, such as earrings, beads, dyed feathers, etc., and other articles of small trade too various to enumerate, the rates of payment not being by any means alike upon different islands, as also the articles of barter most greedily sought after in some fisheries not being in demand upon others, which necessitates a trading agent to have some previous knowledge of the various localities where the shell is obtainable, and of the especial likings of the natives, in order to drive a successful traffic.

Many old fisheries out of which great profit has been made (such as Tukau, from whence Messrs. Hort Brothers, in I 856-57, obtained, in less than I 2 months, I 20 tons of shell, with 15 Paomotu divers, and the help of the wives which they took to themselves upon the ground) are now supposed to be exhausted, or (as in the case of Mangarongaro, where there has been for some time back an outcry about small shell) so far depreciated by constant fishing, and not giving 
them time to grow to maturity, as to be now of little value. This is a mistake in both instances; the best of the shell lies still in deep water, and in the great coral caverns underneath the exhausted shelves, from whence the savages, by judicious persuasion, can be easily induced to bring them to the surface. There are some lagoons in which any great quantity, and in some cases no shell whatever, is now supposed to exist; yet there are at those places very considerable deposits, which have been overlooked for the reason that the fishers, not finding any in the shoal water had not thought to look elsewhere. The shallow water at these places is skirted by sandy bays, in the neighbourhood of which (as before stated) this mollusc cannot live. Again, where the lagoons run into great bights, where there is no perceptible current, the shoal water is too hot for them; although in the deep hollows they exceedingly abound, but in such manner that they are not easy to be seen, unless a man goes down purposely to look for them. Pearl oysters are like sponges-certain conditions are necessary to their development; whereas, in other localities presenting apparently the same natural aspects, they are not found at all. *

The fishery for mother-of-pearl shells in Western Australia is prosecuted on the north-west coast, about I300 miles from Fremantle; vessels ranging from five ton cutters to large schooners are engaged in it, the work being carried on by native and Malay divers. The natives are very expert at diving, but cannot be depended on to remain steadily at work, and though the Malays have to be paid better wages they are found more profitable and far less trouble. The shells average about one pound each, and are worth $£ 7$ to $£ 8$ the cwt.; so that on a good bank

* H. B. Sterndale in Journal of Applied Science. 


\section{The Commercial Products of the Sea.}

the pursuit is very fruitful. The experience of several seasuns tends to show that the banks are recovered in the course of a year or two, and that the industry has thus a tolerably permanent character. The nearest port is at Nicol Bay, where there is a town and a Government staff. $A l l$ boats engaged in the fishery pay a license of $£ \mathrm{I}$ per ton on the registered tonnage, but never less than $£ 5$ or more than $£ 30$, and the revenue derived from this source is appropriated to services connected with the northern settlements.

The fishery for pearls is carried on at Shark's Bay, latitude about $26^{\circ}$, under the same regulations and in a somewhat similar manner. In winter, however, iron-wire dredges are substituted for diving, and these are drawn across the banks. Hitherto the small shells containing pearls have been found almost exclusively in an inlet, named (curiously enough) Useless Harbour, which is about ten miles wide, the banks lying in the middle of it. The men camp on shore, and the boats, which are chiefly small cutters, go out at eight a.m. till two or three p.m. A boat with four men may bring back eight sacks of shells, and these are thrown on to the large heap on shore, for the animal to rot, when the shells are easily opened. Of course, the product is more uncertain than in the shell fishery. You may find large and valuable pearls, but they are the exception; the average-sized pearls found are remunerative; but it is precarious if carried on on a small scale, and the banks in Useless Harbour are showing signs of exhaustion, while at present no other satisfactory deposits have been found. The export of pearls, however, has gradually increased, and some have realized $£ 200$ to $£ 300$ each.

The pearl shell fishery of Western Australia is becoming a most important trade on the Australian north- 
west coast, between the fifteenth and twenty-fifth parallels of south latitude. Less than seven years ago this trade did not exist, but within the last three years it has gone on increasing in importance, till in 1876240 tons of shells were exported to London and 67 tons to Singapore, chiefly for transmission thence to the same destination. The price now being got per ton is from $£ 250$ to $£ 280$. The trade is chiefly supported by the few squatters resident on the north-western coast, or by small capitalists, who proceed in the proper season, in small craft of from 40 to 80 tons, to the coast where the shells are found; and there engage Malay, Japanese, or Australian natives as divers at almost nominal wages. Last season was a prosperous one, and the trade promises to be of very great importance.

Mother-of-pearl shells of a fine quality now form a large article of export from Western Australia. There have been some recent imports also from Gambia, but I do not believe this shell is met with on the West African coast.

In China there is a good demand for mother-of-pearl shells. They are used for carving and inlaying, and are also manufactured into beads, card-counters or "fish" (as they are often termed, from the shape into which they are cut), spoons, etc.; but they do not seem to be used there for buttons, as in Europe. Three kinds of beads are made in China from mother-of-pearl, one perfectly round, the second not quite round, and the third cut or figured. The card-counters are made in various shapes, round, oval, and oblong, with ornamental figures and engravings on them. They are put up for sale in sets of 140 pieces. A few years ago a set of very elaborately carved or engraved mother-of-pearl shells were sent from China, intended for dessert plates; but, although elegant in the workmanship and labour bestowed on the carving, and most curious, 


\section{The Commercial Products of the Sea.}

they were not suited for the, purpose intended, and therefore unappreciated here.

A similar mode of ornamentation, but less artistic, and of a much coarser character, is familiar in the carved "pilgrim shells," which are brought from Bethlehem and other parts of the Holy Land, having religious legends and figures engraved on them.

One process of working pearl shell is similar to that of engraving metals in relief by the aid of corrosive acids and the etching-point. The shell is first divided as may be necessary, and the designs or patterns drawn upon it with an opaque varnish; strong nitric acid is then brushed over the shell repeatedly, until the parts untouched or undefended by the varnish are sufficiently corroded or eaten away by the acid. The varnish being now washed off, the device, which the acid has not touched, is found to be nicely executed. If the design is to be after the manner of common etching on copper, the process upon the shell is precisely the same as the process upon the metal.

Several other shells, having sufficiently brilliant tints in their nacreous or iridescent hues, are used for some of the industrial and ornamental purposes to which mother-ofpearl is applied, and it will be necessary to give a brief notice of these. The ear-shells (Haliotis family) are much used for inlaying work by the Birmingham manufacturers, to give the varied shades to papier-mâché ornaments and fancy articles. They are sometimes called in trade "aurora shells." There are about seventy species of these splendid shells, of which we have one common British species of small size (H. tuberculata), with a silvery hue. In Jersey, where it abounds, it is called the "ormer." These shells have a row of holes following the course of the spine, and have been named ear-shells from their resemblance in form 
to the cartilage of the human ear. The species of the warmer latitudes furnish the most brilliant shades of colour. Haliotis iris, of New Zealand, is green, highly iridescent. H. Mida, a Cape of Good Hope species, when deprived of its yellowish-brown epidermis, is found more or less tinged with orange and other colours. Some handsome species brought from Japan and other localities are $H$. rufescens, $H$. splendens, and $H$. Cracherodii. The green ear-shell is much used for fancy buttons, studs, sleeve-links, buckles, and earrings.

The people of Guernsey and Jersey ornament their houses with the shells of the ormer, disposing them frequently in quincunx order, and placing them so that their bright interior may catch the rays of the sun. Some of the large and splendid intertropical species, which, after removing the outer layer, take a polish almost equalling the natural brilliancy of the interior, might be converted into dishes for holding fruit; if mounted with good taste, their indescribable iridescence and prismatic colours would materially add to the richness of an elegant table. The ear-shells consist of numerous plates resembling tortoiseshell, alternating with thin layers of nacre, exhibiting, when magnified, a series of irregular folds.

Under the name of Abalones the animal is dried for export by the Chinese in California, and by the Japanese. The pearly shell is used in inlaying, for jewellery, and, when polished, as mantel ornaments. Coarsely pulverized, it is used for decorating letters in ornamental sign-painting.

Another shell much used for its opal tints, its glistening colours of light and dark green, soft yellow, and bright and beautiful pink blended together, is the Turbo olearius or marmoratus, which passes in commerce under the name of the "green snail." These shells used to form the royal 


\section{The Commercial Products of the Sea.}

drinking-cups of the Scandinavian monarchs, and they may often be met with, elegantly mounted in silver and set with jewels, in museums. Small shells of another species, the Turk's cap (Turbo sarmaticus), are sometimes set as pipebowls, and sections are much used for making little fancy boxes, purses, caskets, scent-bottles, postage-stamp cases, tablet-covers, small baskets with metallic handles, buttons, earrings, ring-trays, brooches, etc.

The beautiful effects presented by the nacreous portion of shells is produced, as we have seen, by the disposition of single membranaceous layers in folds or plaits, lying more or less obliquely to the general surface. The tints of many shells are concealed during life by a dull external coat, and the pearly halls of the nautilus are seen by no other eyes than ours. This shell, when bisected, displays the pearly chambers for which the genus is celebrated. Fine specimens of the nautilus are often converted by the inhabitants of the East into drinking-cups, on the surface of which they engrave various devices and ornaments. When the outer coating (which is usually of a dingy white colour) is entirely removed, the beautiful pearly appearance of the shell becomes visible. Sometimes the nautilus shell is mounted as a stand for flowers on the table or mantelpiece.

Pearl shells are often employed for ornamentation in the papier-mâché manufacture work, which, though it has gone much out of fashion in this country, is still in extensive demand in America and on the continent. The articles chiefly made are small fancy tables, chairs, trays, portfolio covers, and such like. There are two ways of employing the pieces of pearl shell. When a considerable number of pieces of thin shell are required of the same size and pattern, they are cemented together with glue, 
and the device or figure drawn upon the outer plate. They are then held in a vice or clamp, and cut out as one plate with a fine saw, or wrought into form with files; drilling tools can be employed to assist in the operation. To separate the pieces, the cemented shells are thrown into warm water, which softens the glue and divides them. Cast or sheet iron and papier-mâché are the materials upon which pearl is generally fixed or inlaid. The process is as follows :-

If the article be of cast iron, it is well cleaned from the sand which usually adheres to the casting, and is blackened with a coat of varnish and lamp-black. When this is 'thoroughly dried, another coat of japan or black varnish is spread evenly upon it. Before the varnish becomes too dry, pieces of pearl cut in the form of leaves, roses, or such flowers as the fancy of the artist may dictate or the character of the article may require, are laid upon it, and pressed down with the finger, and they immediately adhere to the varnished surface. The work is then placed in a heated oven, and kept there for several hours, or until the varnish is perfectly dried. It is then taken from the oven, and another coat of varnish applied indiscriminately on the surface of the pearl and the previous coating, and again placed in the oven till dry. This process is repeated several times. The varnish is then scraped off the pearl with a knife, and the surface of the pearl and the varnish around it is found to be quite even. The pearl is then polished with a piece of pumice-stone and water, and the surface of the varnish is rubbed smooth with powdered pumice-stone, moistened with water. It is in this unfinished state that the pearl has the appearance of being inlaid, and from which it derives its name. Its final beauty and finish depend altogether on the skill of the artist who now receives it. 
402 The Commercial Products of the Sea.

\section{- Chapter iII.}

PEARLS AND THE PEARL FISHERIES.

Great demand for pearls-Mode of formation-Large and valuable pearlsShells on which they are formed-Statistics of the Ceylon pearl fisheriesMode of prosecuting the fishery-Classification of pearls-Value of pearls imported into England-Persian Gulf fishery-Panama fishery-Pacific fisheries-Pearls from river mussels-Celebrated pearls.

HAVING treated of mother-of-pearl and its applications, we are necessarily led next to the consideration of the muchprized pearls themselves, which are held in such high estimation for personal decoration by ladies, and even by the stronger-minded sex in the East, where Indian princes are radiant in pearls, and the trappings of their elephants are profusely covered with these gems of the ocean. The native princes, in their interview a few years ago with the Viceroy of India at Barwal, had their elephants beautifully caparisoned with masses of pearls on the head. Holkar had his chest completely covered with strings of pearls and emeralds. This much-admired ornament is appreciated in all parts of Eastern Asia, from the Himalayas to the Pacific, and from Manchuria to the Straits, being in requisition for the decorations of shoes, girdles, earrings, necklaces, and head-dresses, and for the embellishment of popular divinities. The frequent mention of pearls in Chinese history shows the value set upon them by the 
Imperial court, and by all who were ambitious of adorning their persons. Pearls of two and three inches in circumference are spoken of. Mingti, a Chinese monarch of the early part of the tenth century, celebrated for his extravagance, had such a profusion of pearls ornamenting his canopy, the trappings of his horses and chariots, and decorating his person and the persons of his nobles, that the road was often strewn with the gems which the gorgeous cortége dropped in its train. A custom was prevalent, termed "scattering in the palace," in which embassies from tributary States strewed pearls about in abundance; indeed, on one occasion, a garment composed of strings of pearls was thus presented.

It is debatable ground whether pearls come strictly under the term "gems," but they are, at least, very precious in price and general estimation. The value of the pearls owned in Europe, America, and India must be considerable, if we consider what have been the accumulation of ages, how eagerly the search for them is still prosecuted, . and how anxious those having wealth at command are to possess the choicest of their kind. We have but very imperfect data on which to frame any reliable estimate of the Western commerce in pearls. A large dealer has assured me that from $£ 100,000$ to $£ \mathrm{I} 20,000$ is about the annual value of those received here. If we examine the official Board of Trade returns we find that the declared and computed value of the pearls, set or unset, imported into the United Kingdom in the 18 years ending with 1870 , exceeded $£ \mathrm{I}, 000,000$ sterling.

This, be it remembered, is much under the true value, and relates only to Great Britain, whilst quantities are brought in unrecorded. If we consider also how many are sent to the East, and are sold on the continent and in 


\section{The Commercial Products of the Sea.}

America, we may be able to form a slight conception of the great importance of pearls in an artistic and commercial point of view. The Io fisheries for pearls carried on, on the coast of Ceylon, between I833 and I863, brought in to the Ceylon Government $£ 300,000$, but what the speculators made by the pearls they obtained it is quite impossible to state.

The ordinary pearls of commerce are an excretion of superimposed concentric laminæ, of a peculiarly fine and dense nacreous substance, consisting of membrane and carbonate of lime. The best are obtained from bivalves, but some are formed by univalves, which are more curious than valuable.

In the class of mollusca which inhabit the seas and fresh waters, most of those with shells secrete a horny and calcareous substance, that is, combined animal and mineral, formed on the interior of the shell during their growth, and they also form that admired substance known as mother-ofpearl. The superabundance of this secretion is often produced in drops, balls, or tuberosities, adhering to the interior of the valves, or lodged in the fleshy part of the animal. In the latter instance they are of a spherical shape, and increased annually by a layer of pearly matter ; they remain brilliant, translucid, and hard.

At the Maritime International Exhibition which was held at Naples in I87I, the various ocean treasures employed in art were displayed in great profusion and magnificence. Even the Italian journals became poetical and enthusiastic upon the manifold attractions of the hall of pearls and coral. Marchisini, of Florence, showed a wonderful collection of pearls; among others, a brown pearl, valued at $£_{5000}$, and three necklaces of large white oriental pearls, finished and ornamented with brilliants, etc. 
To this exhibitor was awarded the great gold medal, not for finish as works of art (for those of Franconini and R. Phillips, of London, which were far superior, were passed over), but merely as the most rare and valuable collection of pearls shown.

Bellega has a high reputation for Italian jewellery. His collection at Naples also received a medal from the jury, and included a diadem of pearls, turquoises, and brilliants, and a variety of other objects.

Phillips Brothers, of Cockspur Street, exhibited a very large and curious-shaped pearl, tastefully mounted and set as a triton.

The best pearls are of a clear, bright whiteness, free from spot or stain, with the surface naturally smooth and glossy. Those of a round form are preferred, but the larger pear-shaped ones are esteemed for earrings. According to the position the pearls occupy, they partake of the character of the shell near which they are formed. Thus, the pearls from the centre of the nacreous shells are of the usual pearly structure of those shells, while the pearls formed on or near the outer coat of the Pinna squamosa are of the same brown colour and prismatic texture as that part of the shell. Those from the Placuna placenta are of a lead colour, while even from the true pearl oysters (Avicula margaritifera) they are frequently of a light, semi-transparent straw colour. Those formed on the part of the common mussel shells are of a bluish colour.

The dark-coloured pearls are usually little esteemed; in general they are obtained from the black-edged or smoky mother-of-pearl shell. Pearls of a considerable size are sometimes found attached to the shell, and being carefully removed and filed, are strung with the perfect pearls, as the convex part of the pearl which was in contact with the 


\section{The Commercial Products of the Sea.}

shell is often of the same size and perfect form with the part which projects beyond the surface of the shell.

Pearls of this description, but not so perfect at the point of contact with the shell, serve the jeweller equally well for the purpose of setting as the perfect pearl. Some of those on the shell, and others detached, may be seen in the fine collection of $\mathrm{Mr}$. Beresford Hope at the South Kensington Museum. Mr. Hope possesses the largest known pearl, weighing three ounces, or 1800 grains; its length is two inches, and its circumference four and a half inches. The drawers and cabinet of pearls of Messrs. Hunt and Roskell, of London, are an attractive sight to inspect.

The Duke of Abercorn has a wonderfully fine pearl drop. The beautiful parures of pearls of the Countess of Dudley won the admiration of the thousands who visited the London Exhibition of I872. One necklace alone of singularly fine pearls was valued at $£ 30,000$. Many other remarkable sets of pearl ornaments belonging to the nobility and gentry were also shown there.

Although fine pearls are for the most part strung pure and simple, requiring nothing to add to their intrinsic value and beauty, yet occasionally the taste and art of the jeweller are called in to combine them into graceful forms of ornament, with the addition of diamonds, for earrings, brooches, coronets, and other head-ornaments.

Very often, in purchasing job lots and miscellaneous collections of rough pearls, some extraordinary finds are made. Thus, among some apparently of small value from Australia, bought by Messrs. Hunt and Roskell, one was discovered which sold for $£ 800$; and several fine large pearls had been destroyed in colour and value from the aborigines having roasted the oysters which contained them. Frequently a very fine pearl will be found attached to the 
mother-of-pearl shells, which the pearl workers purchase at the London sales in bulk. When carefully detached, high prices have thus been frequently obtained. The natives, when the oysters are collected, generally drill a hole in the mother-of-pearl shell, or break it up to get out any real pearls there may be in it; but occasionally they miss one, and Mr. Wright, a pearl-button manufacturer, states that about 15 years ago a workman in Birmingham found, in one of the shells he was employed upon, a very large and perfectly formed pearl, which he disposed of for $£ 40$, and which was afterwards resold for $£ 200$. Small pearls are frequently found in this way, some perfect, and others only of irregular formation. In the instance referred to, the pearl was perfect in form, and of the shape and size of a small damson.

The jeweller will often split a pearl, which serves for setting solid. The Scotch river pearls are very frequently set with a solid mass of gold.

The Russian Cabinet, which purchases largely for the Czar, possesses a magnificent and valuable collection of pearls. The late emperor shared with his wife a fancy for choice and fine pearls, and had them sought for all over the world. They had to fulfil two conditions rarely to be met with. They must be perfect spheres, and they must be virgin pearls, for he would buy none that had been worn by others. After 25 years' search, he at last succeeded in presenting his consort with a necklace such as the world had never seen before. The Crown Prince of Prussia presented his bride at her marriage with a splendid necklace, of 36 fine pearls, which excited the envy of many a lady who saw it. This admiration for fine pearls has been a common weakness in all ages and in all countries. 
408 The Commercial Products of the Sea.

It was long supposed that pearls were only formed in bivalve shells, and it was therefore difficult to understand what shell it was that yielded the pink pearl, for no known bivalve of any size has such a coloured inner surface. It is now ascertained that the pink pearl is produced, among others, by one of the porcelaneous or chank shells (Turbinella scolymus). All doubt on this head is set at rest by a specimen of this shell in the British Museum, where a fine large pink pearl has been caught and embedded in the shell, near its aperture, just as it was about to escape. The pearl is exactly like the internal surface of that shell. These pink pearls are also produced by the common fountain-shell of the West Indies (Strombus gigas), and are known in commerce as conch pearls. Some very fine pink pearls were shown from the Bahamas at the London International Exhibition of 1862 . These pearls, however, fade, as do the pink cameo brooches. The giant clam (Tridacna gigas), the common oyster (Ostrea edulis), the horse-mussel (Modiola vulgaris), and many other bivalves, yield pearls, but they are generally opaque and valueless.

Small seed-pearls are obtained in the Eastern seas from the semi-transparent molluscous shell, Placuna placenta or orbicularis, and are chiefly used for medicinal purposes in China. Some of the finer ones are selected as jewellers' pearls, but these are of a different character and lustre to the pearls produced by the Avicula margaritifera and the Meleagrina margaritifera, which is abundant in the Sulu Archipelago.

Although pearls are obtained in the seas and rivers of many parts of the world, yet the fisheries have been prosecuted on a large scale, for the purposes of commerce, in only three or four localities-in the Gulf of Manaar, on the pearl banks of Ceylon, Aripoo, and Tuticorin in 
Southern India; in the Persian Gulf, off the island of Bahrein; in the Bay of Panama, and the Gulf of California, and on the shores of Australia about the Pacific Islands.

The revenue derived from the pearl fishery in Ceylon is uncertain and precarious, but worth fostering. The Dutch had no fishery for 27 years, from 1768 to 1796 , and they were equally unsuccessful from 1732 till 1746 . Under the British Government, the right of pearl fishing was let to Mr. John Jervis, a merchant of the East India Company; but $\mathrm{Mr}$. Jervis got nervous, and allowed some natives to go in for the chances at $£ 60,000$, who are said to have cleared three times the amount by this adventure. The fishery right, in I 797, was purchased by Candappa Chetty, a native of Jaffna, for $£ \mathrm{I} I 0,000$; but the fishery was prolonged, and on counting up, the net profits were found to be $£ 144,000$. The same renter purchased the fishery of 1798 for $£$ I 40,000 . The fishery was again prolonged, and yielded a clear revenue (including other gains) of $£ 192,000$. The banks having been exhausted, the proceeds of the fishery in 1799 fell to $£ 30,000$. From I 799 till 1802 inclusive, the average yearly produce ranged from $£ \mathrm{I} 2,000$ to $£ 55$,000 per annum; in $1806, £ 35,000$; but in 1814 the proceeds were $£ 105,187$. There was no fishery from 1820 to 1827 . In the next five years, from 1828 to 1833 , it averaged about $£ 30,000$. In 1834 there was no fishery. In 1835 it brought in upwards of $£ 40,000$. In the next two years it declined to $£ 25,800$ and $£ 10,600$ respectively, and then the fishery was not resumed until 1855, when about $£$ il,000 was realized.

The pearl fishery of I 860 was, as regards revenue to the Government, nearly the most successful that has taken place since the fisheries were resumed. It realized $£ 48,216$; and but for the change of weather which set in at the end of 
4ro The Commercial Products of the Sea.

March and the outbreak of cholera which ensued, there is every reason to believe that the proceeds would have reached $£ 60,000$. The great increase in the selling price of the oysters was owing to the profit (which could not have been less than 300 per cent.) made by the speculators in I 858. The fame of this brought all India into the field as competitors. Money was as plentiful as buyers, and the same oysters which averaged $£ \mathrm{I} I 9$ s. per 1000 in 1858 , in I 859 produced an average of $£ 4$ IOs., the highest rate paid being no less than $£ 88 s$. The two later fisheries realized still higher prices. There is no reason to doubt that, even at these prices, large profits were made.

The fishery of 1860 produced $£ 36,682$ to the Government, the average price paid per 1000 for the oysters being as much as $£ \mathrm{I} 34 \mathrm{~s}$., the highest price given being $£ \mathrm{I} 8$ per I000. In the fishery of I863 the sum realized was a little over $£ 5 \mathrm{I}, 000$, the average price paid for oysters by speculators being $£ 6$ I 4 s. per 1000 .

Ceylon has, during the last 80 years, derived from her pearl fisheries more than a million of money, namely :-

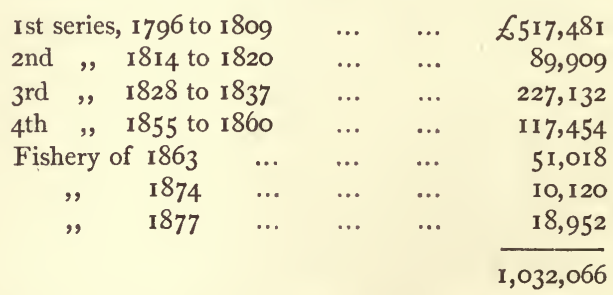

In the last-named year I 527 boats were employed fishing on 30 days, the number of oysters obtained being $6,849,720$.

Experience has shown that but few pearls, and those of but slight value, can be looked for in oysters under five 


\section{Pearls and the Pearl Fisheries.}

years old; from the fifth to the sixth year, however, the pearl oyster doubles in value, and again doubles should it survive to the seventh year. If removed too soon the pearls are imperfectly formed, and, on the other hand, if allowed to remain too long, the fish dies and is lost.

The Ceylon pearl fishery usually lasts for a month or

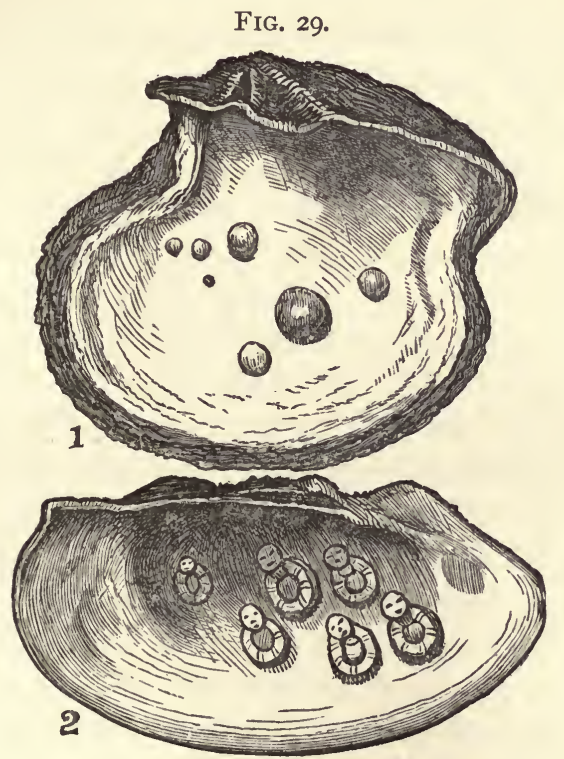

I. Meleagrina margaritifera, the mother-of-pearl shell. 2. Anodonta herculea, the Chinese pearl mussel.

six weeks, commencing about the second week in March, and is carried on to the middle or end of April, when the sea is usually calm and the currents least perceptible. The following is from an account of the fishery which I published in my "Technologist," vol. ii. p. 546:- " The boats employed are divided into two squadrons, each consisting 


\section{I 2 The Commercial Products of the Sea.}

generally of 60 or 70 boats. The squadrons fish alternately. Each boat has its company, five diving-stones, and two divers to each stone. All the men are numbered as well as the boat, and in the Government shed or platform there are divisions with corresponding numbers, so that each boat knows the precise spot where its oysters are to be deposited.

"The squadron starts usually between II and I2 at night, so as to reach the fishing ground by sunrise. The banks are about $\mathbf{2} 2$ miles from the shore. As soon as the boats have arrived the signal is given, and the diving-stones go over the sides of the boats with a low rumbling noise. One diver goes down with each. The other holds the signal rope, watches the motions of his comrade, draws up first the stone, then the net in which the oysters are lodged as torn from the bank, and then the diver himself. Each pair of divers keep their oysters separate from the rest in large nets or baskets, so that luck and labour determine the remuneration of the pair.

"When one man is tired the other takes his place; but they do not dive alternately, as too much time would be lost by changing. The man who has been down, after remaining a minute or so upon the surface, during which he either floats without apparent exertion or holds on by a rope, descends again, and repeats the process, until he requires rest, when he takes his turn on board. This continues without interruption for six hours. Indeed, the stimulus of self-interest brought to bear upon all is so great, that as the time approaches for striking work, the efforts of the men increase, and there is never so much activity as when the heat is most intense, the sky without a cloud, the sun glaring frightfully, and the sea like molten lead. At last the second gun is fired; every stone goes 
down simultaneously for one more haul, and then every hand is employed in making sail, and each boat has her head to the shore. When they reach the beach, in an instant the divers are in the water, and each pair carries the results of a day's work to the shed. Then they divide the oysters into four heaps. In two hours the whole of the boats are unloaded, unless delayed by contrary winds. The divers' share is removed, and the three-fourths belonging to Government left in the shed, divided into heaps of 1000 each, the doors are locked, guards stationed, and everything is in readiness for the public sale.

"This system appears peculiarly well suited to the country, and to the objects in view, by bringing to bear upon the daily results of the fishery the largest amount of private interests and the smallest amount of Government control. No man could be forced into doing what the divers do voluntarily. No fixed payment would induce them to dive so often in the day, or to unload their boats with equal despatch."

The market is a curious sight, always full of people bargaining, purchasing and selling a variety of things. Spectacled Moormen from the coasts of India, with tiny scales and weights before them, and brass pans for sizing the pearls, looking at one strangely from their little huts as he passes by, with that expression of cunning and cleverness at driving a bargain so characteristic amongst their class. Money-changers and petty shopkeepers, with their money and wares spread out on white cloth, line the streets.

The Tuticorin fishery, on the Madras side of the Strait, yielded, in I86I, about $£ \mathrm{I0,000}$ revenue. In the middle of the last century the fishery here brought in to the Dutch East India Company a yearly tribute of $£ 20,000$. On the 


\section{I4 The Commercial Products of the Sea.}

Tinnevelly side the Dutch fisheries were also incessant, almost annual. After the English occupation of Tuticorin there was a fishery in 1822 , which yielded a profit of $£ \mathrm{I} 3,000$ to the Indian revenue. Another in I830 netted $£$ Io,000.

The pearl oyster appears inclined to bid farewell to the shores of Tinnevelly for ever, and various reasons are being alleged as to the cause of its gradual but sure disappearance. We do not pretend to be able to solve the problem, but it is well known that fish cannot live in water beyond a certain density, or be exposed to a pressure of more than three atmospheres, and it is also known that marine animals derive from the water the solid matter which forms their shells. Now, the disgusting filth which the returning tide carries twice in the 24 hours from the beach at Tuticorin, to say nothing of the contribution from the shipping, is sufficient to contaminate the water to such an extent that mollusca less delicate than the pearl oyster might, without exaggeration, be supposed to flee the polluted waters.

Between 1830 and 1856 there were 13 examinations of the banks, and on each occasion it was found that there was not a sufficient number of grown oysters to yield a profitable fishery, and none was attempted again until 1860. In that year the sale of the Government share of oysters by public auction began at I 5 rupees, and gradually rose to 40 rupees $\left(£_{4}\right)$ per 1000 . As many as $15,874,500$ shells were sold, realizing upwards of $£ 20,000$ as the net result to Government, exclusive of all expenses and of the shares allowed to the divers. In I 86I the results of the fishery were equally satisfactory. The price began at $£ 7$ to $£^{8}$ per IOOO shells, and afterwards sank to $£ 4, £ 3$, and 34 s. In 1862 the banks were found to be in a most unpromising state, and no fishery was attempted till I 874 . 


\section{Pearls and the Pearl Fisheries.}

The net revenue derived from the Ceylon fishery for the nine years prior to $\mathrm{I} 834$ was $£ \mathrm{I} 45,000$; in $\mathrm{I} 835$ it produced $£ 40,000$. In 1837 there was a small fishery which realized only $£ \mathrm{I} 0,63 \mathrm{I}$. There was no fishery again until I 855 , when about the same amount was obtained. In I860 the fishery was resumed, and brought in over $£ 36,000$.

In 1877 , after two years' rest, the pearl oyster beds were again thrown open to the divers. The result of the limited period of fishing was looked forward to with considerable interest, as upon its success depend the hopes of the restoration of this decaying industry, and the nature of the treatment to which the beds will in future be subjected, Pearl oysters-or rather mussels, for the bivalve that yields the precious gems is not a real oyster, but a variety of the mussel-produce the largest pearls when they have attained a growth of about four years, and it is consequently the aim of the divers to secure only those which have reached that age. It has consequently been the policy of the authorities in Ceylon to permit the fishing of different beds only once every four years, leaving a comparatively small number of molluscs to replenish the stock. But the objections to that system are that, owing to the numerous enemies by which the shell-fish are surrounded, and other circumstances connected with their development, banks of oysters have been known almost totally to disappear within a single year, when left unfished for more than three or four years; so that, though the temptation to leave the beds untouched for that period, in the hope of securing a supply of large pearls, is very great, the danger that the whole produce may be lost more than counterbalances it. The object, therefore, which the Government has in view in the present operations is to see what is the proper length of time which ought to elapse between different fishings in the same beds. 


\section{I6 The Commercial Products of the Sea.}

Experimental divings made during the last few years showed there was on the banks which are now being fished a harvest of some $10,000,000$ oysters. The average number of pearls to be expected from this quantity of oysters is about two per cent. The average value per Iooo oysters depends, of course, upon the size of the gems. The theory is that, pearl oysters in the last year of their existence double their value all round. If 1000 oysters produce pearls-large and small together-worth $£ 20$, the catch is considered a very good one. A hundred tiny pearls the size of a pin's head are not worth one of the size of a small dried pea, so that the fishing is practically a lottery, in which the prizes are very few and the blanks may be numbered by millions. Indeed, the manner in which the boats are selected, and the order in which they fish, are arranged by lots, the boats being placed in divisions of about 50 each, and sent out one division at a time, till all have had an equal number of chances. About 250 boats are generally employed in the actual fishing operations, and no fewer than 10,000 people are directly or indirectly engaged in the industry. In the great fishery in 1874 the number of oysters taken in one bank alone was I,250,000, which sold for about IOI,200 rupees, or $£$ IO, I 20. These figures will give some idea of the importance of the fishery, and the desirability of restoring, if possible, its productive powers, since the Government, as well as the divers themselves, derive a considerable revenue from the sale of the pearls.

After the pearls are collected they are classed, weighed, and valued. The method of classing them is by passing them through a succession of brass cullenders, called baskets, of the size and shape of large saucers. There are IO, and sometimes I2, of these cullenders: the first has 
20 holes in it, and the pearls that do not pass through these holes, after being well shaken, are called of the twentieth basket. The succeeding baskets have $30,50,80$, I00, 200, 400,600, 800 , 1000 holes; each basket giving the name, corresponding with its number of holes, to the pearls that do not pass through; so that there are pearls of twentieth, thirtieth, fiftieth, and so on, to the thousandth basket. The pearls which do not pass through the eleventh or twelfth baskets, when they are used, are called masie. The pearls having been sorted into IO or I 2 sizes by means of the baskets, are carefully examined in regard to their beauty of shape and colour, and each size, except the masie, is susceptible of seven distinct descriptions. After being classed, they are weighed and valued according to their respective qualities. The price of pearls is expressed at a certain rate per chow, which term has reference to the quality ascertained from the size, the form, the colour, and the weight.

The number of pearls which are valuable as gems, and permanently retained as such, is limited t the larger proportion of the small seed pearls, and of the defective ones, are used as ingredients of a highly prized native electuary; and occasionally the extravagance is committed of reducing them to chunam, or lime, to be used with betel-leaf and areca-nut as a masticatory. The pearl-powder of the apothecary was even a sovereign remedy for many diseases in this country a century ago; but whether it were made of pearls is questionable.

Declared Value of the Pearls imported into the United KINGDOM.

$\begin{array}{rrrrrr}1853 & \ldots & \ldots & \ldots & \ldots & £ 60,735 \\ 1854 & \ldots & \ldots & \ldots & \ldots & 41,001 \\ 1855 & \ldots & \ldots & \ldots & \ldots & 30,476\end{array}$




\section{I8 The Commercial Products of the Sea.}

$\begin{array}{rrrrrr}\mathbf{1} 856 & \ldots & \ldots & \ldots & \ldots & £ 56, \mathbf{r} 62 \\ \mathbf{r} 857 & \ldots & \ldots & \ldots & \ldots & 62,805 \\ \mathbf{1} 858 & \ldots & \ldots & \ldots & \ldots & 78,559 \\ \mathbf{1} 864 & \ldots & \ldots & \ldots & \ldots & 56,236 \\ \mathbf{1} 865 & \ldots & \ldots & \ldots & \ldots & 45,789 \\ \mathbf{1} 866 & \ldots & \ldots & \ldots & \ldots & 51,816 \\ \mathbf{1} 867 & \ldots & \ldots & \ldots & \ldots & 38,096 \\ \mathbf{1} 868 & \ldots & \ldots & \ldots & \ldots & 36,079 \\ \mathbf{1} 869 & \ldots & \ldots & \ldots & \ldots & 45,403 \\ \mathbf{1} 870 & \ldots & \ldots & \ldots & \ldots & 16,675\end{array}$

No later official returns have been published.

The average annual imports of pearls into France are thus given in the French official tables :-

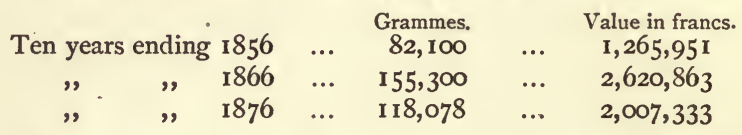

The next large Eastern fishery is that in the Persian Gulf. Colonel Pelly, in an official report to the Bombay Government in I863, stated that the pearl oyster beds extend at intervals almost along the entire length of the Arabian coast of the Gulf. No person other than the coast Arabs is considered to have any right of diving ; and it is probable that any intrusion on the part of foreigners would create a general ferment along the coast line. The richest banks are those of the islands of Bahrein. They are found at all depths, from a little below high-water mark down to I 7 and I 8 fathoms. It is probable that there are beds at a much greater depth. It is held as a rule here that the lustre of the pearl depends on the depth of the water-the greater the depth, the finer the lustre. There does not seem to be any known law governing the more or less sphericity of the pearl.

The diving period is from the warm spring in April to the end of the hot summer months of August and September. There are generally from 4000 to 5000 fishing 
boats along the entire coast, each boat containing from IO, 20 , to 32 men. Of the above number of boats about I 500 will belong to Bahrein.

A large number of the boats employed in the Persian Gulf fishery are in the hands of pearl merchants, whether Hindoo or other, who reside in the towns of the littoral. These agents make advances of moneys to the divers during the non-diving season. As a rule, the diving may be in water of four to seven fathoms in depth. The crew is told off into divers and rope-holders, the former diving, while the latter keep the boat and stand by to haul the diver up.

The value of the Persian Gulf fishery has been usually estimated at $£ 400,000$ a-year. Lieutenant Whitelocke, Lieutenant Wellsted, and other well-informed authorities, give this amount, and Colonel Pelly confirms it recently; for he says the annual out-turn of this pearl fishery is assumed to be as follows:- The Bahrein pearl divers, $£ 200,000$; divers from the Arab littoral of the Persian Gulf, others than Bahrein, $£ 200,000$; total, $£ 400,000$. The great bulk of the best pearls is sent to the Bombay market, where fancy prices are often given for good pearls. A large number of pearls is sent towards Bagdad. As a rule, the Bombay market seeks the pearl of yellowish hue and perfect sphericity; while the Bagdad market prefers the white pearl. The small seed-pearls go principally to Bagdad also. The value of the pearls imported into Bagdad from Bahrein was, in 1865 , about $£ 30,000$; in $1866, £ 25,000$; in $\mathrm{I} 867, £ \mathrm{I} 8,000$; but in the two following years the annual imports did not average $£ 8$,000.

The next fishery of any importance is in Central America, on the Atlantic and Pacific sides ; but even here, from over-fishing, the pearls have become exhausted, the oysters not being allowed to reach maturity. 


\section{The Commercial Products of the Sea.}

In the lower part of the Bay of Mulege, in the Gulf of California, near Los Coyetes, pearls have been found of rare value and astonishing brilliancy. It was in this bay that Jeremiah Evans, an Englishman, towards the close of the last century, obtained those magnificent pearls, of which the collar was made for the Queen of Spain, and which evoked so much admiration at St. Cloud and Windsor Castle. In the time of the Jesuit missionaries, the pearl fishery was actively carried on, and produced great wealth to the people of Lower California.

A very choice large pearl, of a perfect pear shape, and of the finest water, was found a few years ago in the Bay of Panama.

The average annual value of the pearls collected from the Panama fishery has been about $£ 25,000$. It is, however, difficult to arrive with any degree of accuracy at the total value, as the trade is conducted with great secrecy, in consequence of jealousies, not only amongst the pearlmerchants, but even between the divers, who offer their property to the dealer with all mystery and every reservation. From the official statement of exports, pearls to the value of $£^{28,100}$ were shipped from Panama in 1865 , and $£ 23,1$ IO in I867. In I869 we imported pearls of the value of about $£ 40,000$ from New Granada, the Atlantic ports of America, and 'St. Thomas. The pearl fisheries on the Panama side, having been exhausted, are now suspended.

It was from the island of Margarita, off the Colombian coast, that Philip II. of Spain obtained, in I579, a magnificent pear-shaped pearl, weighing 250 carats, which was valued at $£ 30,000$.

In the Gulf of Mexico, when Columbus first discovered some of the islands, he found Indians fishing for pearl 
oysters. The necks of the females were adorned with strings of pearls, which they were induced to exchange for the more attractive novelties of fragments of porcelain ware painted and adorned with gaudy colours. The natives entertain the old fanciful notion which the earlier naturalists did : they suppose the pearls formed from petrified dewdrops in connection with sunbeams. We can, therefore, well credit the astonishment of Columbus and his mariners when, in the Gulf of Paria, they first found oysters (Dendrostrea, Swai.) clinging to the branches of trees, their shells gaping open, ready, as was supposed, to receive the dew, which was afterwards to be transformed to pearls.

The Hindoos poetically ascribe their production to drops of dew, which fall into the shells of the fish in which they are formed. A Brahmin told Mr. Le Beck that the mollusc rises to the surface of the sea in the month of May, to catch the drops in his shell, and that he thus received the germ of a pearl, which is then impregnated by the heat of the sun.

Pliny had probably some version of this Indian idea, and, as usual, he improved the story by the addition of something of his own. He says : "The pearls vary according to quality of the dew of which they are formed; if that be clear, they are also clear; if turbid, they are turbid; if the weather be cloudy when the precious drop is received into the shell, the pearl will be pale-coloured ; if the shell has received a good supply, the pearl will be large; but lightning may cause it to close too suddenly, and then the pearl will be very small; when it thunders during the reception of the drop, the pearl thence resulting will be a mere hollow shell of no consistency."

In I87I the Government of Guayaquil granted permission to the owner of an American schooner to dive for 
pearls on that coast, on condition that one-fifth of the amount was to be delivered to the Government. There seems to be an abundance of pearls of very good quality, and the owner of the schooner was quite content with the trial; 35 ounces, valued at $£ 20$ an ounce, were shipped from there in $187 \mathrm{I}$.

Perforated pearls, destined to serve as beads, often form a part of the contents of ancient North American mounds. Squier and Davis found them on the hearths of five distinct groups of mounds in Ohio, and sometimes in such abundance that they could be gathered by the hundred. Most of them had greatly suffered by the action of fire, being in many cases so calcined that they crumbled when handled; yet several hundreds were found sufficiently well preserved to permit of their being strung. The pearls in question are generally of irregular form, mostly pear-shaped, though perfectly round ones are also amongst them. The smaller specimens measure about one-fourth of an inch in diameter, but the largest has a diameter of no less than three-fourths of an inch. According to Squier and Davis, pearl-bearing shells occur in the rivers of the region whose antiquities they describe, but not in such abundance that they could have furnished the amount discovered in the tumuli; and the pearls of the fluviatile shells, moreover, are said to be far inferior in size to those recovered from the altars. The latter, they think, were derived from the Atlantic coast and from that of the Mexican Gulf. It is a fact that the Indians, who inhabited the present Southern States of the Union, made an extensive use of pearls for ornamental purposes. This is attested by the earliest accounts, and more especially by the chroniclers of De Soto's expedition (the anonymous Portuguese gentleman and Garcilasso de la Vega), who speak of almost fabulous quantities of pearls 
which that daring leader and his followers saw among the Indians of the parts traversed by them. Pearls, however, belonged to the things most desired by the Spaniards, and the accounts relating to them, perhaps, may be somewhat exaggerated. The following passage from Garcilasso de la Vega is of particular interest:-

"While De Soto sojourned in the province of Ichiaha, the cacique visited him one day, and gave him a string of pearls about two fathoms (deux brasses) long. This present might have been considered a valuable one, if the pearls had not been pierced; for they were all of equal size and as large as hazel nuts. Soto acknowledged this favour by presenting the Indian with some pieces of velvet and cloth, which were highly appreciated by the latter. He then asked him concerning the pearl fishing, upon which he replied that this was done in his province; a great number of pearls were stored in the temple of the town of Ichiaha, where his ancestors were buried, and he might take as many of them as he pleased. The general expressed his obligation, but observed that he would take away nothing from the temple, and that he had accepted his present only to please him. He wished to learn, however, in what manner the pearls were extracted from the shells. The cacique replied that he would send people out to fish for pearls all night, and on the following day at eight o'clock (sic) his wish should be gratified. He ordered at once four boats to be despatched for pearl fishing, which should be back in the morning. In the mean time much wood was burned on the bank, producing a large quantity of glowing coals. When the boats had returned, the shells were placed on the hot coals, and they opened in consequence of the heat. In the very first, ro or 12 pearls of the size of a pea were found, and handed to the cacique and the general, 


\section{The Commercial Products of the Sea.}

who were present. They thought them very fine, though the fire had partly deprived them of their lustre. When the general had satisfied his curiosity, he retired to take his dinner. While thus engaged, a soldier came in, who told him that, in eating some of the oysters caught by the Indians, a very fine and brilliant pearl had got between his teeth, and he begged him to accept it as a present for the Governess of Cuba. Soto very civilly refused the present, but assured the soldier that he was just as much obliged to him as though he had accepted his gift; he would try to reward him one day for his kindness and for the regard for his wife. He advised him to keep his (intended) present, and to buy horses for it at Havana. The Spaniards who were with the general at that moment, examined the pearl of this soldier, and some who considered themselves as experts in the matter of jewellery, thought it was worth . 400 ducats. It had retained its original lustre, not having been extracted by means of fire."

Pearls are obtained in some parts of the Eastern Archipelago. Those from the Sulu Islands are very fine. A companion of Magellan mentions having seen two pearls, in the possession of the Rajah of Borneo, as large as pullets' eggs.

From the island of Labuan pearls are sometimes sent to Singapore to the value of about $£ I I, 000$ in a year. In I867, I990 taels of pearls, worth $£$ I0,450, were exported, as against 3853 taels in 1868 , worth $£ 11,554$. In 1869 the shipments were only to the value of $£ 2329$; and in 1870 , to $£ 5686$.

About the Society Islands, where the pearl fishery is carried on, pearls are most frequently found in oysters of medium size, and frequently very fine ones are obtained. M. Cuzent, in his account of Tahiti, published in 1860 , 
states that during his residence there, for one owned by the queen a German merchant had offered $£ \mathrm{I} 200$. Pearls to the value of $£ \mathrm{I} 600$ were shipped from the Navigator's Islands in 1858 . The pearls are there classed under four grades :-

I. Those of a regular form and without faults.

.2. Those of a round form, white, and of a good lustre.

3. Pearls of irregular form, not free from faults or spots.

4. Knots of pearl, or those which have adhered to the shell.

The average value of these kinds, according to weight, ranges as follows:-

Ist Class.-Pearls weighing the tenth part of a gramme are worth about $3 s$. And so on through the intermediate weights up to those weighing $I \frac{1}{2}$ to $2 \frac{1}{2}$ grammes, which are valued at $£ \mathrm{I}$ oO to $£ \mathrm{I} 4 \mathrm{O}$.

2nd Class. - Thirty grammes of pearl, containing 800 'pearls, would be worth only $£ 4$; whilst the same weight in 50 pearls would be worth $£ 60$.

3rd Class.-Thirty grammes of pearls of this kind would be worth from $£ 3$ to $£ 4$, according as the pearls were more or less tarnished by black blemishes or dulness in the lustre.

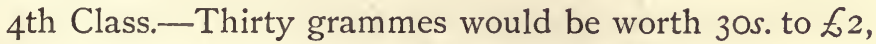
according to their regularity of form and brilliancy.

The commerce in pearls in the Society Islands is estimated at about $£ 4000$ a year. Some are of remarkable beauty; and among others may be noted one belonging to the Queen of the Gambiers, which is of a brilliant orient, and of the size of a pigeon's egg. The large pearls found are, of course, of an arbitrary value; the small, or seedpearls, are sold at $£ 2$ to $£ 3$ the pound at Tahiti. 
426 The Commercial Products of the Sea.

In the Gambier Islands magnificent pearls are found, and also at the Paomotu Isles.

Of all the substances employed in jewellery, the pearl is the one whose value it is the most difficult to establish, because it depends upon so many variable conditions of size, form, and colour. A pearl of the first quality should possess, above all things, a fine "orient," or water. By this expression is meant a pure whiteness, joined to a lovely lustre that sparkles in the light. There are pearls, too, which, with a white colour, show a delicate reflection of azure. These are the most highly esteemed. The second quality of a fine pearl is that it should be perfectly spherical, or regularly pear-shaped. There are a great number of pearls whose colour has a yellowish tinge. This alone is a mark of inferior quality. The following table was made by a celebrated West End jeweller to compare the price of pearls of the first choice in 1865 and I 867 :-

\begin{tabular}{|c|c|c|c|c|c|c|c|c|}
\hline A pearl of & $3 \mathrm{~g}$ & rains & & $\begin{array}{l}\text { s. } \\
\text { I }\end{array}$ & $\begin{array}{l}d . \\
0\end{array}$ & to & & $\begin{array}{c}s . \\
19\end{array}$ \\
\hline ," & 4 & ," & I & 6 & 0 & ,, & $\mathbf{I}$ & 12 \\
\hline ," & 5 & ," & I & 7 & 0 & ,, & 2 & 7 \\
\hline ," & 6 & ," & 3 & 5 & 0 & ", & 3 & 15 \\
\hline , & 8 & ," & 4 & I2 & 0 & ,, & 5 & 14 \\
\hline , & IO & ," & IO & 2 & 0 & ," & I I & 2 \\
\hline , & 12 & , & 14 & 2 & 0 & ," & I6 & I \\
\hline , & 14 & , & 18 & 2 & 0 & , & 20 & 3 \\
\hline ," & I6 & , & 20 & 3 & 0 & , & 30 & 5 \\
\hline , & 18 & , & 30 & 5 & 0 & , & 40 & 4 \\
\hline ,, & 20 & , & 40 & 4 & 0 & ," & 50 & 8 \\
\hline , & 24 & , & 60 & IO & 0 & ," & 72 & 12 \\
\hline , & 30 & ," & 85 & 13 & 0 & ,, & 100 & 17 \\
\hline
\end{tabular}

Besides the individual value which pearls possess in common with all other precious stones, and which is expressed in the preceding table, they have another very important one, which we may call associative value. Thus it happens that two pearls of the same form, the same size, 


\section{Pearls and the Pearl Fisheries.}

the same colour, etc., are worth a much higher price if sold together than when sold apart. A necklace in which the pearls have been chosen from a great number will be held at double the value of a necklace where the pearls have been picked from a smaller number, even when the individual value of the pearls is identical in both. In the first place the harmony will be complete, while in the second case the eye will detect a break in the shades in passing from one pearl to another.

Some mother-of-pearl shells are fished in Torres Straits. It seems that women are there the best divers for the shell. They are more dependable. The pearl-shell oyster is a magnificent mollusc; weighing three to six pounds, and sometimes ten pounds. Divers come up with one under each arm. They are opened at once, the fish used as food, and the pearls, which are few and small, carefully preserved. The shells sell at Sydney for £I50 to £I80 per ton, and a schooner will carry 30 to 40 tons.

The pearl fisheries of Western Australia seem to become more productive yearly; the value of shells exported in I 872 was $£ 25,890$, against $£$ I 2,895 worth exported in the previous year, and the estimated value of pearl shells sent from the colony in 1873 , representing the take of the season $1872-73$, was about $£ 50,000$. The value of the pearl shell exported in 1874 was $£ 58,928$, and of pearls $£ 6000$, which is probably much below the mark. The natives are employed as divers, and work for a mere subsistence; but, owing to the stringent laws existing for the protection of the aborigines, most of the pearling craft-in fact, all who can-employ Malays, whom they bring, under agreement for a term of years, from the Coromandel coast and Java. These men are paid at a rate varying from $£ \mathrm{I}$ to $£ 2$ per month, and are kept free of charge. A diver will 


\section{The Commercial Products of the Sea.}

frequently bring up about $30 \mathrm{lbs}$. weight of shells after one dive. The value of the shells in the colony averages from $£ 7$ to $£^{8}$ per cwt. These shells, the home of the Meleagrina margaritifera, weigh on the average about two pounds per pair, and measure from six to ten inches in diameter. It is to their intrinsic commercial value, rather than to the pearls they contain, that the north-west fisheries owe their importance.

Another lucrative fishery exists in Shark's Bay, a large inlet, extending in a south-easterly direction from Dirk Hartog's Island, about the twenty-fifth degree of south latitude, to a distance of I 50 miles. The shells found in this region are those of the true pearl oyster, the Avicula margaritifera, an oyster only slightly larger than its European congener, and valuable for the pearls it bears. The shells themselves have no commercial value.

A large pearl was found a year or two ago on the northwest coast. It is pear-shaped, weighs I 59 grains, is of a very fine texture, and has an excellent lustre. Its size is about equal to that of a common acorn, though it is of course different in shape. There are one or two specks' on the smaller end, which is also scarcely perfect in its outline, but the thick end is superb, and is not marred by the slightest defect. No fair estimate of its value could be made locally, as there is no Australian market for such gems. The pearl was found by a pearling expedition fitted out from the port of Melbourne.

The subject of marine pearls can scarcely be dealt with without a brief allusion to the river pearls which are obtained from the Alamodon, Anodonta, Unios, and other shells, in different countries.

Many of the fresh-water mussels produce pearls in the mountain-streams of Britain, Lapland, and Canada; but 
they are generally inferior in lustre and value to the marine pearls. Some worth $£ 3$ to $£ 4$ each have, however, been frequently obtained, and specimens of great individual value have ranged from $£ 50$ up to $£ 100$. It has long been known to naturalists and antiquaries that pearls of great beauty and size have been found from time to time in the Scotch streams.

Tytler, in his "History of Scotland," states that, so early as the twelfth century, there was a demand for Scotch pearls abroad. Those in the possession of Alexander I., he says, were celebrated for their size and beauty. In I355 Scotch pearls are referred to in a statute of the Parisian goldsmiths, by which it was enacted that no worker in gold or silver should set them with oriental pearls, except in large ornaments or jewels for churches. They are noticed again in the reign of Charles I., when the Scotch pearl trade was considered of sufficient importance to be worthy of the attention of Parliament. The following extract from "An Accompt Current betwixt Scotland and England," by John Spruel, Edinburgh, I 705, shows that they were then well known :- "If a Scotch pearl be of a fine transparent colour and perfectly round, and of any great bigness, it may be worth $\mathrm{I} 5,20,30,40$, to 50 rixdollars; yea, I have given 100 rix-dollars ( $£ \mathrm{I} 69 s .2 d$.) for one, but that is rarely to get such. . . . I have dealt in pearls these 40 years and more, and yet, to this day, I could never sell a necklace of fine Scots pearl in Scotland, nor yet fine pendants, the generality seeking for oriental pearls, because farther fetched. At this very day I can show some of our own Scots pearl as fine, more hard and transparent, than any oriental. It is true that the oriental can be easier matched, because they are all of a yellow water, yet foreigners covet Scots pearl." 


\section{The Commercial Products of the Sea.}

These British pearls were well known to the Romans, who, nevertheless, complained that they were small and ill-coloured. History has preserved the tradition that it was this source of wealth that tempted the Romans to our shores, and more than one ancient writer refers to the shield, studded with British pearls, which Cæsar suspended as an offering in the temple of Venus, at Rome. Tacitus mentions pearls among the products of our island, but adds that they were generally of a dusky, livid hue. This, he suggests, was owing to the carelessness and inexperience of the persons who collected them, who did not pluck the shell-fish alive from the rocks, but were content to gather what the waves cast on the beach. Pliny and others also describe them as inferior, on account of their dulness and cloudiness, to the jewels of the East. Coming down to times less remote, we find Hector Bœce, in the sixteenth century, expatiating upon the pearls of Caledonia with much enthusiasm. They were, he says, very valuable, "bright, light, and round, and sometimes of the quantity of the nail of one's little finger."

It seems known that Sir Richard Wynn, chamberlain to the queen of Charles II., presented her Majesty with a pearl taken from the river Conway, which, it is affirmed, is still honoured with a place in the regal crown. In the sixteenth century, several of great size were fished from the Irish rivers. One that weighed 36 carats was valued at $£ 40$, and other single pearls were sold at from $£ 4$ IOs. up to $£$ IO. This last was disposed of a second time to Lady Glenlealy, who put it into a necklace and refused $£ 80$ for it from the Duchess of Ormond ("Philos. Trans. Abr.," p. 83).

Oliver Goldsmith, in his "Natural History," refers to a pearl fishery rented on the Tay; and Hugh Miller has 
spoken of rivers in the north famous for their pearls. As a branch of industry, however, the Scotch pearl fishery seems to have been well-nigh forgotten, when, in I860, M. Moritz Unger, a foreigner then in Edinburgh, conceived the idea of making a tour through the districts where the pearl mussel was known to abound. He discovered that pearl fishing was not altogether forgotten, and found pearls in various parts of the country, in the hands of people who did not estimate their value. He purchased all he could procure. The consequence was that, in the following year, many persons-colliers, masons, labourers, and othersbegan to devote their leisure to pearl fishing, and some of them were so successful as, during the summer months, to make as much as $£^{8}$ to $£$ IO weekly. Between the years 1761 and $1764, £ 10,000$ worth of pearls were sent to London from the rivers Tay and Isla, but the trade carried on in the corresponding years of this century was far more than double that amount. M. Unger estimated the pearls found in 1865 to be of the value of about $£ \mathrm{I} 2,000$. In the summer of $\mathrm{i} 862$, which was dry and favourable to fishing operations, more pearls were produced than during any previous year in Scotland, and at that time the average price of a Scotch pearl was $£ 26 s$. to $50 s$. ; $£ 5$ was considered a high price. Since the fisheries were revived, their price has rapidly risen, and they now fetch prices ranging from $£ 5$ to $£ 20$. One Scotch pearl was bought by Her Majesty for 40 guineas. The Duchess of Hamilton and the Empress of the French also purchased fine specimens at high prices, and M. Unger had in his possession a necklace of Scotch pearls, which he valued at $£ 350$.

A good pearl should be either globular or pear-shaped ; according to Jeffries, a celebrated jeweller, "their complexion must be milk-white, not of a dead and lifeless, but 


\section{The Commercial Products of the Sea.}

of a clear and lively hue, free from stains, fouls, spots, specks, or roughness." He condemns all coloured pearls, although the Hindoos prefer a yellow tinge, and some nations admire the red. He values them according to their weight, in the following manner:-A pearl of one carat (three grains and one-fifth) is valued at $8 s$.; one of two carats at four times that amount; one of three carats at nine times, and so on in a square proportion, multiplying the number of carats by itself and the product by $8 s$. But the price set upon some pearls of ancient days exceeds this estimate enormously; and even now a pearl of very extraordinary beauty would most probably receive a valuation upon other grounds than its weight.

The enormous value attached in ancient times to some extraordinary. pearls seems to be almost fabulous. Much of this must, of course, be attributed to the caprice which will pay any price, however excessive, for whatever is unique of its kind, the possession of which may be an object of competition; and the manufacture of artificial pearls had not then lowered the price of the real jewel. But though no longer so extravagantly valued, the pearl must always be a favourite; its delicate and silvery lustre, in the words of an admirer, "relieves the eye of gazing at the brilliancy of the diamond, as the soft brightness of the moon after the dazzling fire of the sun."

There were the often-mentioned pearls of Cleopatra, one of which that celebrated queen drank dissolved in vinegar before Marc Antony, while the other, saved from a similar fate, was slit into halves to form earrings for the statue of Venus in the Pantheon. Julius Cæsar presented to Servilia a pearl valued at $6,000,000$ sesterces, or nearly $£ 50,000$. Clodius, the glutton, swallowed one worth $£ 8000$. 
The example of Cleopatra found an imitator even in sober England. Sir Thomas Gresham, not otherwise famous for acts of folly, still so mistook the meaning of loyalty that he ground a pearl, which had cost him $£$ I 5,000, into a cup of wine in order thus fitly to drink the health of his great queen!

The pearl belonging to the Shah of Persia, seen by Tavernius in 1633 , was valued at 32,000 tomans, equal at that time to double the number of pounds sterling. It is said to have been obtained at Catifa, in Arabia, where a pearl fishery existed in the time of Pliny. It was pearshaped, perfect in all respects, and nearly three inches long. This pearl is believed to be the one which was in possession of the late King of Persia, Fateh Ali Shah.

A pearl presented by the republic of Venice to Soliman, the Emperor of the Turks, was valued at $£ \mathrm{I} 6,000$. The large pearl in the crown of the Emperor Rudolph II. weighed 30 carats, and was the size of a pear. (?) Pope Leo X. bought a pearl of a Venetian jeweller for the sum of $\dot{£} \mathrm{I} 4,000$. A lady in Madrid, in the year 1605 , wore an American pearl which cost $3 \mathrm{I}, 000$ ducats.

A large Java pearl, curiously set, was shown at Madrid a few years ago. It was made to represent a siren, or mermaid, dressing her hair; her body was formed of the pearl, which was of a long oval form, and beautifully pure white; the head and arms were of white enamel, and the lower extremity, forming the fish, of green enamel. The whole was finely carved, and on the girdle were the following words : "Fallunt aspectus cantusque syrenis."

The most beautiful pearl known is in the Museum of Zosima, in Moscow. It weighs very nearly 28 carats. It is perfectly globular, and so beautifully brilliant that at first sight it appears transparent. It was bought by Zosima at 


\section{The Commercial Products of the Sea.}

Leghorn, of a captain of an East India ship. This splendid pearl, which has been named the Pellegrina, is one of the objects of a visit to Moscow.

In the French crown jewels there are some very fine pearls. Among others, a collection of 408 pearls, each weighing 16 grammes, of a perfect white, round, and of a magnificent orient. They are valued at $£ 20,000$. Also a pearl as large as a pigeon's egg, of a very beautiful quality, valued at $£ \mathrm{I} 600$, and others of less value.

"As this admiration for fine pearls has been the common weakness of man in all ages and in all countries, we need not wonder at their playing a prominent part in religious writings. The Talmud has a pretty story, teaching us that those who believe in it esteemed but one object in nature of higher value than pearls. When Abraham approached Egypt, the book tells us, he locked Sara in a chest that none might behold her dangerous beauty. But when he was come to the place of paying custom, the officer said, 'Pay custom.' And he said, 'I will pay the custom.' They said to him, 'Thou carriest clothes.' And he said, 'I will pay for clothes. Then they said to him, "Thou carriest gold.' And he answered them, 'I will pay for gold.' On this they further said, 'Surely, thou bearest the fine silk.' He replied, 'I will pay custom for the finest silk.' Then they said, 'Surely, it must be pearls that thou takest with thee.' And he only answered, 'I will pay for pearls." Seeing that they could name nothing of value for which the patriarch was not willing to pay custom, they said, "It cannot be but thou open the box and let us see what is within." So they opened the box, and the whole land of Egypt was illumined by the lustre of Sara's beauty-far exceeding even that of pearls.

"Hence pearls are repeatedly used in Holy Writ also for 
the most solemn comparisons, and to denote the highest degree of perfection. In the Old Testament wisdom is praised as above pearls; and in the New Testament the kingdom of heaven is compared to a pearl of great price, which, when a merchant had found it, he went and sold all that he had, and bought it. Even the New Jerusalem was revealed to St. John under the figure of an edifice with twelve doors, each of which was a single pearl." *

* " Putnam's Magazine." 
436 The Commerial Products of the Sea.

\section{CHAPTER IV.}

CORAL AND THE CORAL FISHERIES.

Scientific description of coral-Varieties of-Commercial classifications of coral - Statistics of trade in France and England-Seats of manufacture in Italy-Various coral fisheries in the Mediterranean-Statistics of boats employed-British imports of coral-Indian trade in coral.

SCIENCE and commerce frequently work hand in hand, and materially aid each other; but in some instances commerce has been in advance of science, and this may be said of the search for coral and its application for ornament, which have been prosecuted for ages by the uninformed, whilst learned naturalists have been debating many moot points as to the growth, formation, and special localities of the coral varieties.

Our scientific men are busy dredging and exploring the great depths of the ocean, but they have as yet thrown little light on those questions which are of paramount importance to the fishers for and workers in coral-as, for instance, why the important banks of good coral are limited to the Mediterranean Sea, and what are the requirements of these polypes for the aggregation and formation of this now much sought for article of commerce. As I remarked in a lecture delivered before the Society of Arts a few years ago, we are still ignorant on many points of the highest 
importance relating to the production and collection of this handsome substance. The little that we do know, however, leads to the belief that the growth of coral is rapid; that

Fig. 30.

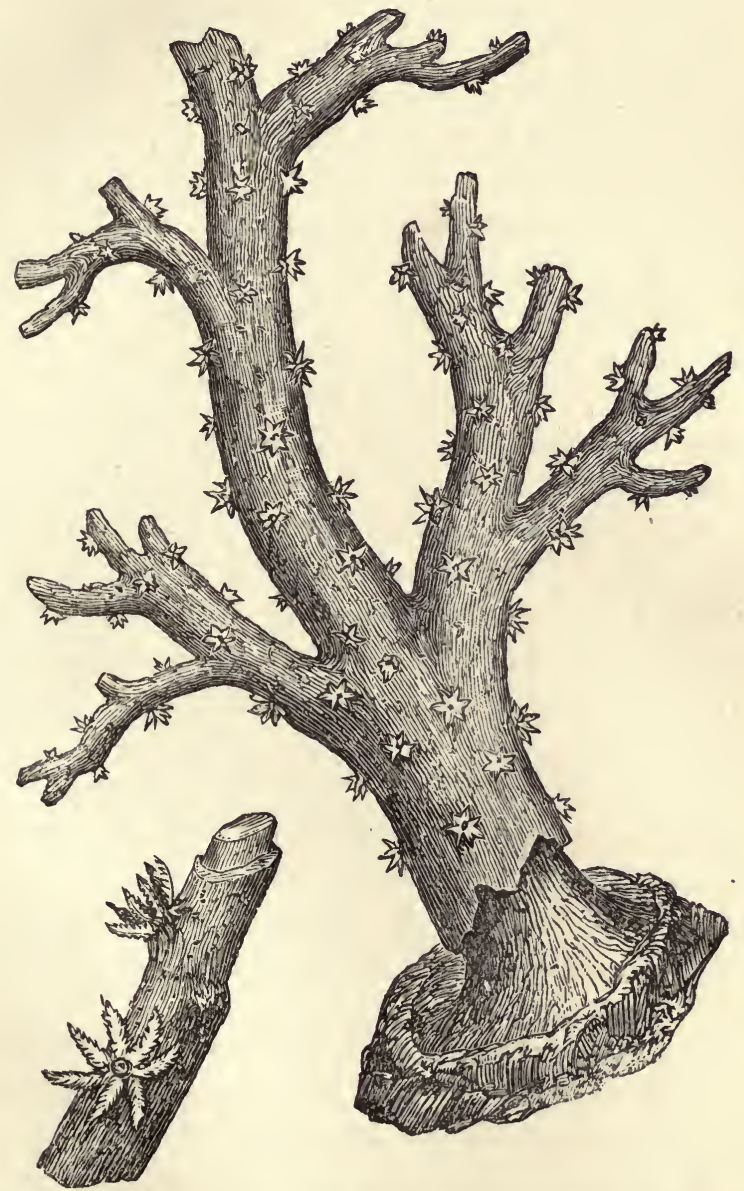

Corallium nobilis, or red coral ; with a piece magnified, showing the polypes. 


\section{The Commercial Products of the Sea.}

its development is simple, and accommodates itself to very varied circumstances; that detached fragments from the bunch or principal stem have a vitality, and will voluntarily attach themselves to certain fixed substances, for continuing their development and forming new trunks; in fact, objects thrown into the sea in the vicinity of coral banks will infallibly be found covered with coral in a few months. 'But what is most valuable to be known in regulating the search for coral, and for rendering the return more productive and more certain, is to ascertain at what age coral attains its largest size; how long it takes for an exhausted coral bank to again become rich and flourishing; at what period the eggs are laid; how are the products disseminated; at what period does the budding take place, and how long does it last? These are most important questions, on the solving of which rests the complete regeneration and progressive increase of the coral fishery, and they are questions as yet unsolved by naturalists.

Professor Lacaze-Duthiers, who was charged with a mission to the coast of Algeria to report upon this zoophyte, has given us the results of his investigation and curious experience :-

"To describe correctly," he says, "a branch of coral, we must bear in mind the peculiar property of germination which belongs to the immense class of zoophytes, and we can then consider it as a colony of individuals derived from one zoophyte, itself originating from an ovum or egg.

"The stem of the coral is divisible into two constant and distinct parts: a central axis, hard and brittle, like stone, which is the part used in commerce, and a soft covering or epidermis, which easily yields to the nail when it is fresh, but is friable or brittle when dry. 
"This epidermis appears indented by small cavities upon its surface, and we can often perceive radiated pores corresponding to these cavities. In observing the live coral, we see that out of these holes protrude the little flowers that the naturalists Maligny and Peissonnel recognized as the animals, and which they compared to small seanettles.

"Nothing can equal the delicacy and graceful disposition of these little milk-white rosettes, which contrast admirably with the brilliant red of the coral.

"Their arms, which surround their mouths, are ciliated, or covered with fine fringes, which, ever moving and agitating the water, create a circular current that carries to the centre, and consequently into their mouths, the minute matters that sustain them.

"The epidermis is composed of a very delicate white tissue, and presents through its whole thickness the long cavities of the polypes. It is traversed by canals, which are very numerous, and establish a solidity between all parts, sprinkled with small calcareous corpuscles, hard, resisting, and all armed with unassailable bundles of points, having a special form.

"The structure of the animals is otherwise very simple; they present the appearance of a pocket or of an open purse. The mouth is surrounded with arms, and conducts to the central or penetrating cavity the food, and there we find eight lamillæ radiating towards the centre."

There are various kinds of coral, so-called, to be met with in the shops of shell-dealers and naturalists sold under the name of fan coral, brush coral, brainstones, etc., which serve for ornamenting chimney-pieces, cabinets, museums, drawing-room tables, aquaria, etc. Such, for instance, as the white coral, formerly called Madrepora 
440 The Commercial Products of the Sea.

virginea, and now named Oculina virginea, the brainstone coral (Mendrina cerebriformis), the black coral (G. Antipathes), and the organ-pipe coral (Tubipora musica), which takes its name from the regular arrangement of its cylindrical dark crimson tubes side by side. Being much cheaper than the ordinary solid red coral, this last kind is frequently used as a representative of coral in cabinets of economic products.

But it is with jeweller's coral that we have to deal, which is alone used for articles of personal decoration and works of art. Occasionally the red coral is found white,

\section{FIG. 3I.}

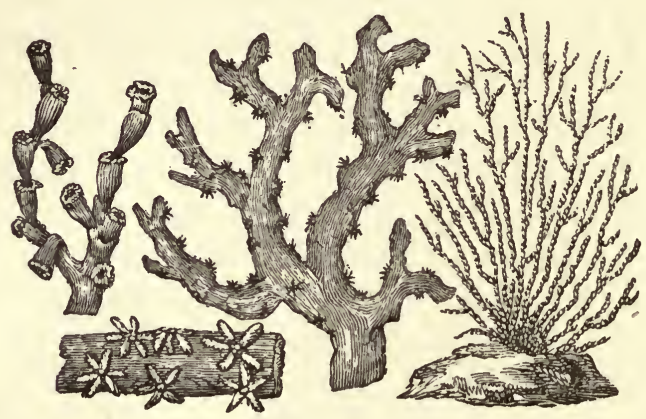

Varieties of coral.

or without any colouring matter; the tips are bored, and the pieces are threaded into negligees, or they are cut into links for forming chains. At the Naples Maritime International Exhibition a magnificent branch of black coral from Trapani was shown, which formed a finish to the trophy of aboriginal arms and weapons exhibited from the Pacific. At Jedda there is a black coral fishery which extends fifty miles north and south. From taking a fine polish, the black is fashioned into beads and mouth-pieces 


\section{Coral and the Coral Fisheries.}

for cigars. The dull white is not quite so hard, and from not polishing well is sold cheaper. It is often deteriorated by being worm-eaten.

Coral is, after pearls, the handsomest and most valuable production obtained from the sea. Naturalists range it, in the animal kingdom, at the head of zoophytes or animalplants. It presents to the fisherman the appearance of a branching shrub without leaves, of a red or rose colour, compact and solid. Coral has the hardness and brilliancy of agate; it polishes like gems and shines like garnet, with the tints of the ruby. The larger branches are used for carving, and as the material is durable, well suited to give definite outlines to the sculptor's work, great labour and ingenuity are frequently expended on objects of art wrought in this material. The Chinese, Hindoos, and Singalese have all tried their skill in carving coral, but the finest and most artistic work emanates from the Italian workshops of Naples, Genoa, and Leghorn.

Large, perfect, well-shaped beads are by far the most valuable form of coral, and these have greatly increased in estimation of late years. Many of the finest are sent to China, where they are in demand for the mandarin's red button of rank worn on the cap. Some of the natives of India have a preference for what may be called wormeaten beads, and tons of these, which would not find favour in Europe, go to the East, where they are esteemed from a superstitious belief that gods dwell in the little recesses or cavities of this coral.

The Chinese, who are most patient and skilful in all their work, used to prepare strings of small rows of seedcoral beads for embroidery, the boring of which was most minute. The practice or art would seem to have become obsolete, for I have only met with strings of them in the 


\section{The Commercial Products of the Sea.}

collection of Messrs. Phillips, Cockspur Street, London, where they are shown as a great curiosity.

A large part of the coral is wasted in the process of grinding and filing to convert it into uniform well-shaped beads, and this, of course, adds greatly to the cost. It is not every one who can obtain and possess such a magnificent row of coral beads as the well-known necklace belonging to Mrs. Edward Baring.

Much of the manufacturing process-grinding, drilling, and polishing the coral-is carried on by women. The working of beads consists of three different operationscutting, piercing, and rounding-and is principally executed by the females of the Val du Bisagno, in Italy. The manner in which it is distributed among the different communes affords a striking example of the principle of subdivision of labour.

All the operatives employed in cutting belong to about Ioo families in the commune of Assio; those in piercing and rounding to about 60 families living in other parts of the valley. Every village works exclusively at beads of a fixed size. In Genoa each manufacturer employs from Io to 20 or more women, who submit the coral to a preparatory process before it is given to the workers of Bisagno. Thirty or 40 men and women are employed in their own homes in cutting coral into facets. There are also about 30 engravers. of coral and cameos. In all from 5000 to 6000 persons gain their livelihood in the province of Genoa either by fishing for, working on, or selling coral, and this craft produces a revenue of $£ 80,000$. Exports of coral are made from Genoa to Austria, Hungary, Poland, England, Aleppo, Madras, and Calcutta.

Those who are connoisseurs of coral know that of late years it has risen considerably in the estimation of the fair 
sex. A somewhat arbitrary standard of beauty has, however, been established in regard to the colour. We must no more think of a choice piece of coral when we talk of "coral lips," than we must of a bigarreau when we speak of "cherry lips." Coral, to be rare and valuable, must be of a delicate pinkish, flesh-like hue, uniform in tint throughout, and in large pieces.

The principal commercial varieties distinguished are red, subdivided into deep crimson red, pale red, and vermilion, which is rare; black, clear white, and dull white, which is the most common. The delicate rose or fleshcoloured, which is the most prized, is sold at very high prices, as it is entirely a fancy article.

Red coral is classified by some dealers into twelve shades of colour, besides the white and pink coral.

In some countries red coral is classified into the following five commercial grades:- I, froth of blood; 2, flower of blood ; 3, 4, 5, blood of first, second, and third qualities.

Madrepore and other showy corals are used for ornamental purposes. The horny axis of black flexible coral (Plesaura crassa) is used for canes and whips in the Bermudas, and the axis of fan coral (Rhipidogorgia) for skimmers in the same islands. Coral is used for building purposes in the Pacific islands, Mauritius, the Seychelles, and other places. Coral rock of recent formation (Coquina) is employed in Florida in the manufacture of ornamental vases and earrings. Calcined coral is used for dentrifices, as an antacid, etc. Lime is also made by calcining coral and coral rock.

The dealers and workers in coral recognize rough tips and polished tips, fragments, roots of branches, suitable for making earrings, and coral tulips for shaping into 


\section{The Commercial Products of the Sea.}

ornaments. The branches of coral assume the espalier shape and other forms. Negligée, collette, and olive-shaped beads are made.

Coral is valued according to its bulk, colour, soundness and freedom from defects. Certain rare kinds, of pale tints, are worth 20 times their weight in pure gold.

The ornamental applications of coral are very varied,negligées, beads (buhls and boutons), bracelets, brooches, ear-drops, tiaras, combs, hair-pins, chains, crosses, links ; studs, and scarf-pins for gentlemen, settings for rings, charms, pendants, parasol garnitures, cameos, and foliage ; coral and bells for children; and watch-cases are sometimes inlaid with pale rose-colour coral.

The Romans used to hang beads of red coral on the cradles and round the necks of infants, to "preserve and fasten their teeth," and save them from the "falling sickness." In modern days they are used to prevent the skin of the neck from chafing, and the child's coral and bells is not yet obsolete.

The general use of coral dates back to the fifteenth century, under Francis I. Naples, Genoa, and Leghorn have been from old times the three great centres to which the raw material has been carried, and where skilful artificers have established themselves in order to work at its transformation into ornaments. In the four principal manufactories, and at several second-rate establishments for working on coral in Leghorn, there are more than Iooo women employed preparing about 50,000 lbs. weight of coral into little beads, round, egg-shaped, smooth and cut into facets, etc. The greater part is sent to India; a large portion is exported to Germany, especially for necklaces of an inferior quality destined to serve as funeral ornaments, and some to Russia, where coral is in great 
demand. France does not use much coral for ornaments, but the fashion there is reviving.

The average annual imports of rough coral into France have been as follows :-

\begin{tabular}{|c|c|c|c|}
\hline ten & $\operatorname{lin} \alpha$ & Kilogrammes. & Value in francs \\
\hline e ten ye & 1050 & $\begin{array}{ll}\ldots & 10,450 \\
\ldots & 19,960\end{array}$ & $\begin{array}{r}253,804 \\
\mathbf{I}, 4 \mathbf{1 8}, 976\end{array}$ \\
\hline & 1876 & 21,596 & $1,890,35^{6}$ \\
\hline
\end{tabular}

The imports of worked coral, unmounted, in the same period was as follows :-

$$
\begin{array}{rrrrrrr} 
& & \multicolumn{3}{c}{\text { Kilogrammes. }} & \multicolumn{2}{c}{\text { Value in francs. }} \\
1856 & \ldots & \ldots & 6,600 & \ldots & \ldots & \mathbf{1}, \mathbf{1 2 5}, 805 \\
\mathbf{1} 866 & \ldots & \ldots & 11,831 & \ldots & \ldots & 3,060,010 \\
\mathbf{1} 876 & \ldots & \ldots & 14,553 & \ldots & \ldots & 5,078,062
\end{array}
$$

In America and the West Indies the black population have a great fancy for coral. Morocco buys largely, and so does India. The caravans transport bijous and jewels fashioned of it to the interior. There, according to religious custom, the dead carry with them to the tomb the ornaments they have worn in their lifetime, and each year sees buried a quantity of coral, more or less considerable, which has to be replaced. Coral manufactories employing a large number of workmen exist at Marseilles. The exports of manufactured coral from Europe were stated in 1862 to be of the value of $15,000,000$ francs $(£ 600,000)$, of which Marseilles made about 2,000,000 francs.

As few persons have access to the bulky returns constituting the Blue Books of the Board of Trade, which give the statistics of the annual imports of various articles into the United Kingdom, it may be desirable to condense the figures as regards coral, so as to furnish a retrospect of the commerce in this marine product. The three items enumerated in the returns are "Coral in fragments," "Coral, whole, polished or unpolished," and "Coral negligées." 


\section{The Commercial Products of the Sea.}

Coral beads are also imported done up into strings of assorted sizes, making five necklaces, also in large bundles of 36 strings assorted, weighing 135 ounces troy. A most objectionable procedure in the coral trade is the practice of attaching to the beads great masses of raw silk and cotton at the ends, amounting to fully 30 per cent. of the weight, and as coral is sold by the ounce, this is an absolute fraud on the buyer. The official statements of the imports of coral into the kingdom are, no reliable criterion of the actual value of the trade, because it is chiefly the coarse and rough coral that is entered at the Custom House; merchants, jewellers, and, indeed, private individuals, who purchase in the Mediterranean the finer kinds of coral, and jewellery made of it, do not trust it in cases as merchandise, but bring it in their personal baggage. The aggregate net value of all the coral imported, according to the Customs returns, never reaches $£ 50,000$ in the year, and, indeed, in the last years of which we have any official record it was under $£ \mathrm{I} 8,000$ or $£ 20,000$; but this is a very fallacious statement, for probably the value of the coral exceeds $£ \mathrm{I00,000}$ a year. Taking, however, only the computed official value of that entered at the Customs, there was received in England, between 1860 and 1870 , coral of different kinds valued at upwards of $£ 300,000$.

In weight the quantity of the several kinds imported varies considerably. Thus, of coral in fragments, sometimes, as in 1856 and $1861,14,000$ to $16,000 \mathrm{lbs}$. weight are received,-in ordinary years the average is not half that amount. Of whole, or perfect pieces, the quantity ranges from 400 to $1000 \mathrm{lbs}$. Of negligées, the quantity has declined considerably. In I 859 about 3000 lbs. weight came in, but the last few years it has only averaged 
500 to $600 \mathrm{lbs}$. In beads there is the same fluctation in the quantity. Some years from 3000 to $4000 \mathrm{lbs}$. come in ; of late years there is only an average of $1000 \mathrm{lbs}$. These figures represent merely the merchant's coral for re-export, and furnish no estimate whatever of the choice coral of fashion, which depends for its value entirely on the goldsmith's and jeweller's art in arranging and setting, variety, form and style, and represents a value far surpassing all that has been quoted. It comprises articles of beauty and imagination which defy any detailed description, and which even illustration could not do justice to.

Coral beads were always favourite ornaments in this country. In the inventory of one John Post (who died in I 524), "late $y^{e}$ king's servant," in the churchwarden's accompts of St. Mary-at-Hill, London, we find the following items: " $\mathrm{I} \frac{1}{2}$ oz. of corall, $2 s .6 d$.; jewels for her body, a pair of corall bedes, gaudyed with gaudes of silver and gilt, IO oz. at $3 s .4 d$., $£$ I I $3 s .4 d$." - a goodly price in those days.

Various handsome parures of coral have been shown from time to time at the different International Exhibitions. Some very fine specimens of red coral in the natural state were exhibited in the Algerian Court at the London Exhibition in $\mathbf{1 8 6 2 . ~ T h e ~ I o n i a n ~ I s l a n d s ~ a l s o ~}$ exhibited some small specimens of coral from Ithaca. From New Caledonia a substance having some resemblance to coral was also shown under the name of "rose coral."

A set of pink coral shown at the Dublin Exhibition in 1865 , consisting of a tiara, bracelets, solitaires, comb, earrings, brooch, necklace, and pendant, was valued at $£$ I000, though the value was represented almost alone by the coral. Signor Gismondi, the designer and carver of 


\section{The Commercial Products of the Sea.}

the set of ornaments had, it was stated, been 20 years collecting the pieces inserted therein. Of the carving of the coral into flowers and foliage, it need only be said that it was as delicate as it was bold and deep, and sustained the reputation of the Italians for skill in glyptics.

Guiseppe Martucci, of Naples, also showed at the Dublin International Exhibition in 1865 an arabesque coral handle for a parasol, eight inches long, carved in relief out of a single piece, with fruit, animals, leaves, etc., valued at $£ 72$.

The International Maritime Exhibition held in $187 \mathrm{I}$ at Naples, the head-quarters of the coral dredging and working operations, afforded an admirable opportunity for displaying some of the finest specimens of natural and artistic productions. On that occasion the leading coral workers and jewellers sent magnificent examples. Mr. Phillips, being a commissioner, was placed hors concours. Casalta and Morabito exhibited coral sets valued at from 9000 to I6,000 Italian lire or francs; but their best work was a walking-stick, with a carved handle of coral weighing 100 grammes, and a fine string of pale white coral. Some of the carving and workmanship shown by Michele Piscione and others were very fine. Ascioni Brothers had a magnificent collection of works in pink and white coral, and especially the carved hilt of a dagger.

At the Paris Exhibition of 1878 , in the Italian section, magnificent carvings in pink coral were shown by Luigi Casalta, Giacinto Melillo, Nicolo Piscione, Guiseppe Giojuzzi, and Rocco Morabito, of Naples.

The value of ordinary red coral fluctuates much at the seat of the fisheries. In I 867 it was only worth $30 s$. the pound, and occasionally it is worth $£ 2$ the pound. The variation in price arises in some degree from the different 
qualities of the coral, but also from special circumstances which the markets of distant countries cause, the sale of coral being much smaller in Europe than elsewhere. The fishermen, however, have attained to a degree of shrewdness and overreaching which is very remarkable. If, for instance, they are successful in finding a fine branch of the coveted pale rose coral, they will not dispose of it alone, but make it the medium for getting rid of their whole stock, covenanting that the purchaser shall take the entire lot for some fixed sum. The purchase of coral by the dealer becomes, therefore, quite a lottery; for until the bark, as it is technically termed, is removed, he knows not what is the condition of the coral. Much of it may be rotten or worm-eaten, and only very little of it solid and of a useful character for working up.

The most ancient seat of exploration for coral was Sicily. In the time of Cosmo I. of Medici, it was introduced by this prince at Pisa, where Sicilian workmen were located, and where, up to the present day, as well as in Leghorn, there is a certain trade in coral.

Trapani has, however, always been the great seat of art manufacture in coral, and some masterly pieces of work, mythological and religious subjects, have been turned out there. Indeed, a royal coral factory was established and encouraged at Portici, near Naples, by Murat, during his sovereignty.

His Grace the Duke of St. Albans possesses a fine carved head in coral, evidently of Greek workmanship, which proves that this material for artistic purposes is of very ancient origin.

The value of the coral annually obtained from Sardinia is about $£ 60,000$, which, after deducting all expenses, leaves a net profit of $£ \mathrm{I} 3,000$. The quantity exported 


\section{The Commercial Products of the Sea.}

ranges from 200,000 to $250,000 \mathrm{lbs}$. It is chiefly found in the shallow waters near Carloforte, Alghero, a province situated on the west coast, and the island of Maddalena. At Alghero, where the growth of coral is the most plentiful, about I90 vessels, manned by 1930 sailors, are employed in the fishery from March till October.

This industry annually acquires larger importance, and the fishing is prosecuted with increased energy. The greater part of the boats employed are Italian, and they take to Genoa, Leghorn, and Naples their produce, which forms one of the principal branches of the trade of the peninsula.

The barks sent to the fishing are solid and well adapted for the labour ; their rig is a great lateen sail and a jib or stay-sail. The stern is reserved for the capstan, the fishers, and the crew. The fore part of the vessel is fitted for the requirements of the patron or master.

The lines, wood, and irons employed in the coral fisheries are called the engine. It consists of a cross of wood formed of two bars, strongly lashed or bolted together at their centre; below this a great stone is attached which bears the lines, arranged in the form of a sack. These lines have great meshes, loosely knotted together, resembling the well-known swab. The apparatus carries 30 of these sacks, which are intended to grapple all they come in contact with at the bottom of the sea. They are spread out in all directions by the movement of the boat. The coral is known to attach itself to the summit of a rock and to develop itself, forming banks there, and it is to these rocks that the swab attaches itself so as to tear up the precious harvest. Experience, which in time becomes almost intuitive, guides the Italian fisher in discovering the coral banks. The craft employed in the great fishery have 
a "patron" or captain, the bark having a poop, with a crew of eight or ten sailors; and, in the season, the fishery is continued night and day.

When the patron thinks that he has reached a coral bank he throws his engine overboard. As soon as the apparatus is attached, the speed of the vessel is retarded, the capstan is manned by six or eight men, while the others guide the helm or trim the sails. Two forces are thus brought to act upon the lines-the horizontal action of the vessel and the vertical action of the capstan. In consequence of the many inequalities of the rocky bottom, the engine advances by jerks; the vessel yielding more or less, according to the concussion caused by the action of the capstan or sail. The engine seizes upon the rugged rocks at the bottom and raises them to let them fall again. In this manner the swab, floating about, penetrates beneath the rocks where the coral is found, and is hooked on to it. To fix the lines upon the coral and bring them home is a work of unheard-of labour. The engine long resists the most energetic and repeated efforts of the crew, who, exposed almost naked to the burning sun of the Mediterranean, work the capstan to which the cable and engine are attached, while the patron urges and excites them to increased exertion, and the sailors trim the sail and sing, with a slow and monotonous tone, a song the words of which improvise in a sort of psalmody the names of the saints most revered among the seafaring Italian population.

The lines are finally brought home, tearing and breaking blocks of rocks, sometimes of enormous size, which are brought on board. The cross is now placed on the side of the vessel, the lines are arranged on the deck, and the crew occupy themselves in collecting the results of their labour. 


\section{$45^{2}$ The Commercial Products of the Sea.}

The coral is gathered together; the branches of precious zoophyte are cleansed and divested of the shells and other parasitic products which accompany them; finally, the produce is carried to and sold in the ports of Messina, Naples, Genoa, and Leghorn, where the workers in jewellery purchase them.

The boats employed are of two classes. One kind, by far the most numerous, is composed of vessels of from I I to I6 tons burden, with crews of I 2 to I4 men. They are all fitted out at Torre del Greco, under the Italian flag, and fish during the months of February and March. The second class includes craft of from three to six tons burden, under the French flag, although they are almost entirely manned by Italian seamen. Their crews consist of five or six men, and they continue at sea most part of the year. The boats fish on the coasts of Africa and Sardinia, at a distance of 15 to 30 miles from shore, only returning to port in case of urgent necessity. They work night and day without intermission; half of the crew relieve the other half every six hours. The larger class of vessels is fast superseding the small, and it is calculated that there are now about 200 of the larger vessels employed, with 2400 men. The seamen receive from $£ 20$ to $£ 24$ each per annum, and the masters about twice that amount. The entire value and equipage of a large boat, including dragnets, stores, and six months' wages, may be estimated at about $£ 550$. Such a boat may probably collect from 650 to $850 \mathrm{lbs}$. of coral in the season.

Hitherto the fishery has been conducted on the old primitive method of the drag-net or rough dredge, formed of a cross of wood with a quantity of hemp attached, to tear up the coral. One would have supposed, with the enhanced value which coral now commands, some efforts 


\section{Coral and the Coral Fisheries.}

would have been made to improve the processes for procuring the branches from the sea bottom.

The diving-bell has been attempted for coral fishing, but, like the pearl fisheries, it does not succeed. An Italian named Foseli has, however, been lately experimenting with a submarine vessel of his invention intended for coral fishing. It was tried satisfactorily at Boza, in the Bay of Naples, in the presence of leading men of the Italian naval, scientific, and civil service. The invention consists of wrought-iron plates divided into three compartments, of which the lowest contains I000 lbs. of ballast; the second or middle chamber is prepared to accommodate two persons; the third or uppermost chamber is filled with compressed air. This compressed air, by means of ingenious machinery, is capable of supplying means sufficient to sustain the life of two persons for 50 hours. At one of the late experiments, this vessel descended to a distance of 38 fathoms below the surface of the water, and remained submerged for $22 \frac{1}{2}$ minutes, without the slightest discomfort being experienced by the navigators. The specific gravity of the ballast serves to retain the vessel in an upright position, and peculiarly simple machinery enables it to move in any direction. An attached illuminating arrangement renders objects within a large area perfectly visible. Other varieties of the machine, for sponge and pearl fishing, requiring a deeper descent, are designed by the inventor.

The Spanish fishermen collect, off the Cape Verde Islands, about $24,760 \mathrm{lbs}$. of coral, of the value of $£ 20,000$.

On the south coast of Corsica, coral of various qualities is found in large quantities. The coral fishery is entirely in the hands of the Italians. About 60 boats are employed annually; each boat, fishing on an average for six months, 


\section{The Commercial Products of the Sea.}

obtains from four to six hundredweight of coral in the rough, which is at once carried over to Italy.

Coral is found in more or less abundance along the coast of the Regency of Tunis, Algiers, and the shores of Morocco. The French Government, between 1806 and 1824, made repeated attempts to renew its engagements with Tunis for a monopoly of the coral fishing, but it was not until I 852 that France obtained the exclusive privilege over the coral fisheries in the Tunisian waters for the annual payment of $£ 355$.

The coral found on the Barbary coast is principally red, but white and black, as well as the much-prized pink, also exist. The latter kind is most frequently obtained on the Galita and Fratelli rock banks. There are about 90 coral fishing-boats at La Calle and 20 at Bona, chiefly owned by Italians, three or four only being the property of Maltese, who reside permanently in Algeria. From 80 to 100 vessels fitted out at Torre del Greco arrive yearly at the proper season at $\mathrm{La}$ Calle, and 50 or 60 make Biserta their fishing station. The coral fishery is but little practised by the French, although a few boats follow this industry in the Mediterranean; several of them use the diving apparatus to collect the coral. The exports from Algeria are valued annually at about $£ 80,000$. There are about 6000 Italians and Spaniards engaged in the Algerian fishery. The French sailors do not like the hard work and short food.

On the Algerian coast the number of boats engaged in this fishery has averaged of late years about 300 , more than two-thirds of which are Italian. The quantity of coral obtained it is difficult to state precisely, but according to the declarations of the fishermen it would appear to avęrage 35,000 kilogrammes. 
The coral is here divided on arrival into several categories, of which the following are the principal :-

I. Dead or rotten coral. In this class is included the roots adhering to the rock and covered with stony particles and vegetable encrustations. The value ranges from 5 to 20 francs the kilogramme.

2. Black coral. This kind, with a polished black tint, is employed for making mourning jewellery; if of good quality it fetches from 12 to 15 francs the kilogramme, or more.

3. Coral in case. This name is given to coral which has been assorted and cleaned when taken from the sea, and consists of branches of all sizes. It is worth from 45 to 70 francs the kilogramme.

4. Choice coral. This is the finest selected coral, in large branches, which the fishermen sell separately as high as 400 or 500 francs the kilogramme, according as the stems are more or less straight, and of handsome appearance.

The expenses and returns from the coral fishery in this locality are thus estimated by M. Lacaze-Duthiers :*-A large boat of 15 or 16 tons, manned by 12 men, involves on an average an outlay of II,000 francs for a season of six months. A boat which obtains in the season 250 kilogrammes of coral, at 50 francs, covers its expenses. A boat which obtains 300 kilogrammes realizes, according to the quality of the coral, a profit of 2000 to 3000 francs. The fishery with the diving-bell is much more advantageous.

The same author estimates the annual yield of the coral fishery on the coasts of Algiers and Tunis at 2,500,000 francs, and the value of the produce when worked up at $12,000,000$ francs; so that the fishery, the working, and

* " Natural History of Coral," I vol., large 8vo., coloured plates. Paris, J. Baillière and Son. I864. 
456 The Commercial Products of the Sea.

the sale of coral gives employment to a good deal of capital.

A year or two ago a new coral reef was discovered on the coast of Palmi in Calabria, and the local sailors fished up a large quantity of rose-coloured coral of good quality, and many pieces of considerable size were obtained. The reputation of the bank soon drew the attention of the bold fishers of Torre del Greco, and three boats were forthwith equipped and sent there, and did well.

Imitations of coral have been tried, but with not very great success. A few years ago coraline, a tolerably cheap substitute, was very common for beads, bracelets, etc., and might be seen in the galleries of the Palais Royal, Paris, and other shops where cheap jewellery is sold. Although it imitated tolerably well the rose-pink coral, yet the artificial beads were too regular, smooth, and uniform to pass muster among those who had any knowledge of the true marine product, and it is scarcely seen now. Even the natives of the East, who are thought to be shrewd and wellinformed on all matters of gems and jewellery, may occasionally be imposed upon. Strings of large coral beads of uniform size, 100 on a string, are in great demand for chaplets in parts of Asia, and a visit was once paid to the shop of Messrs. Phillips by a number of distinguished foreigners, who admired the beauty and proportions of the chaplets submitted to them, but expressed unbounded astonishment at the price asked. Not long after their departure they came back, expressing great indignation at the imposition attempted to be practised on them, declaring that they had purchased a similar article for one-tenth or one-twelfth the price asked, and they exposed numerous strings of coraline. They were asked to put the two articles to the test with a knife, and the true coral was, of 


\section{Coral and the Coral Fisheries.}

course, unassailable, while the artificial composition splintered and broke. The result was an appeal to the police court for redress for the fraud that had been practised on them.

Ivory beads are sometimes dyed to imitate coral; but this seems a sad waste of good material, the natural ivory being preferable to the tinted.

A coral bank of superior quality was discovered, in the middle of May, I875, by a Sicilian fisherman, in the waters of Sciacca. As the fishermen there were not familiar with this mode of fishing, they invited the fishermen of Torre del Greco and of the port of Empedocle to come over and instruct them, at the same time offering them a share of the profits. Soon all the boats of the neighbouring coasts arrived at the bank, which caused such frays that the authorities judged it necessary to station a man-of-war there.

The bank, about 550 yards in length in the direction of west-south-west by east-north-east, and about 30 yards in thickness, yielded at first rich supplies: a small boat with eight men collected from 30 to $40 \mathrm{lbs}$. of coral a day; the coral sold at I Is. per lb., less five per cent. tare, so that each boat showed a daily gain of $£ 20$. But the bank was gradually exhausted, and the coral diminished in value; by the 15 th of July it had fallen to $7 \mathrm{~s}$. per lb., with eight per cent. tare, and towards the end it did not sell for more than $2 s .6 d$. per $1 \mathrm{~b}$., with ten per cent. tare. It was estimated that from the Ist of June to the 3 Ist of August, 1875 , the quantity of coral fished up amounted to $264,000 \mathrm{lbs}$. The coral sold at an average price of $7 s$. per lb., therefore the total fishery brought in $£ 92,400$.

It is well to note that the fisherman who discovered the bank only received the small sum of $£$ IO as reward, and 


\section{The Commercial Products of the Sea.}

this he had to collect halfpenny by halfpenny from the fishermen.

Mr. Herries, in a report of 1868 on the industrial condition of Italy, stated that there were then 365 boats employed in the coral fishery, of which 267 belonged to Naples, and the rest to Leghorn and other places on the Genoese coasts. These boats employed 2699 men and boys. The value of the produce ranged from $£ 280$ to $£ 320$ for each boat during the season.

About 160 tons of coral are annually brought into Italy, and the articles made of coral, exported, are valued at nearly $£ 500,000$.

At the Maritime Exhibition held at Naples in I87 I, the following statistics were published respecting the Italian coral fishery :-

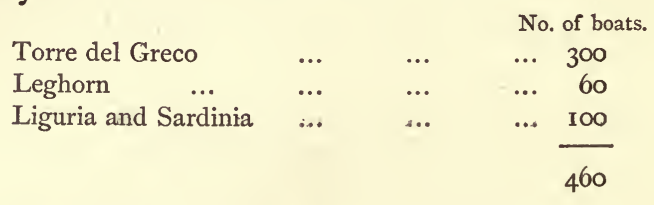

The value of the large boats was $£ \mathrm{I} 60$, and of the smaller ones $£ 80$; the collective capital, $£ 7$ I,000. There were from 6 to 12 men employed in each boat, making a total of about 4000 . The wages paid was about $£ 80,000$, and the provisions came to half as much more. The coral fishery gave employment to some 6000 persons. Each boat, in order to defray the necessary expenses disbursed for outfit, provisions, wages, etc., ought to obtain 200 kilogrammes of coral, which, at an average of $£ 28 s$. the kilogramme, would yield $£ 480$. The coral received in the kingdom of Italy was stated to amount to 160,000 -kilogrammes, worth about $£ 380,000$.

The shops working on coral were stated to be-at Torre 
del Greco, 24; Leghorn, I5; Genoa, 20. Later statistics make the boats engaged in the fishery from Torre del Greco 329, and the workshops there, 40. The workmen employed were about 6000 , who gained $£ 200,000$, or an average of a little more than 35 francs annually.

There were 239 boats engaged in the fishery on the Alghero banks, Italy, in 1873 , and 159 in 1874 . The coral obtained was as follows:-

\begin{tabular}{|c|c|c|c|c|}
\hline & Red coral. & White coral. & Total. & Value. \\
\hline $\begin{array}{l}1873 \\
1874\end{array}$ & $\begin{array}{c}\text { Kilogrammes. } \\
25,384 \\
12,260\end{array}$ & $\begin{array}{c}\text { Kilogrammes. } \\
9536 \\
675^{8}\end{array}$ & $\begin{array}{c}\text { Kilogrammes. } \\
34,920 \\
20,018\end{array}$ & $\begin{array}{r}E_{160}, 080 \\
93,960\end{array}$ \\
\hline
\end{tabular}

The coral fishery of Cagliari gave employment in I 875 to 180 boats, and the produce was below $1,000,000$ francs, against $2,350,000$ francs obtained in 1874 .

The manufactured articles sell, of course, at much higher prices than when in the rough state, so that coral is by no means an inconsiderable source of emolument to the Italians.

Great quantities, when manufactured, are exported to India, and in Leghorn and Genoa several establishments work exclusively for that distant market, where blood-red coral, the colour of which harmonizes with the dark complexions of the native ladies, is particularly in demand. Coral beads of a large size are in high estimation throughout Hindostan, and are usually sold for their weight in silver. Manufactured coral to the value of $£ 208,000$ was sent from Brindisi to Egypt in I873.

The following return furnishes the official quantity and value of the imports of coral and coral articles into the 
460 The Commercial Products of the Sea.

United Kingdom for a series of years. The returns cannot be carried down later than 1870 , as the Board of Trade has ceased to enumerate coral specially:-

Imports OF CORAL INTO THE UNITED KINGDOM, OF DIFFERENT KINDS, IN POUNDS WEIGHT.

\begin{tabular}{|c|c|c|c|c|c|}
\hline Year. & Fragments. & Whole. & Negligées. & Beads. & Total. \\
\hline & lbs. & lbs. & lbs. & lbs. & lbs. \\
\hline 1855 & 2,172 & 285 & 1718 & - & - \\
\hline 1856 & 13,270 & 308 & 2780 & - & - \\
\hline 1857 & 28 & 218 & I 872 & - & - \\
\hline I 858 & 645 & 397 & 1840 & 一 & - \\
\hline 1859 & $\mathrm{I}, 255$ & 621 & 2955 & - & - \\
\hline 1860 & 338 & I I 34 & 1633 & 3568 & 6,673 \\
\hline I 861 & I 5,639 & 84 & 602 & 3654 & 19,979 \\
\hline 1862 & 1,468 & 50 & I 224 & 1427 & 4,169 \\
\hline 1863 & I83 & 318 & 586 & 1829 & 2,916 \\
\hline 1864 & 3,617 & 758 & 446 & 3000 & 7,821 \\
\hline 1865 & 2,914 & 391 & $25^{8}$ & 994 & 4,557 \\
\hline I866 & 4,439 & 276 & 232 & 1385 & 6,332 \\
\hline 1867 & 7,539 & 225 & I I5 & 2543 & 10,422 \\
\hline I 868 & 7,120 & 262 & 724 & 4375 & I 2,48 I \\
\hline 1869 & 5,332 & 786 & $4 \mathrm{II}$ & I 210 & - \\
\hline I 870 & 1,600 & 418 & 652 & $95^{8}$ & - \\
\hline
\end{tabular}

Computed Net Value of Coral imported-Rough, Negligées, BEADS, ETC.

$\begin{array}{lllllr}\mathbf{1} 860 & \ldots & \ldots & \ldots & \ldots & £ 38,892 \\ \mathbf{1} 86 \mathbf{1} & \ldots & \ldots & \ldots & \ldots & 33,403 \\ \mathbf{1} 862 & \ldots & \ldots & \ldots & \ldots & 20,163 \\ \mathbf{1} 863 & \ldots & \ldots & \ldots & \ldots & 22,657 \\ 1864 & \ldots & \ldots & \ldots & \ldots & 37,659 \\ 1865 & \ldots & \ldots & \ldots & \ldots & 13,970 \\ 1866 & \ldots & \ldots & \ldots & \ldots & 17,899 \\ 1867 & \ldots & \ldots & \ldots & \ldots & 29,487 \\ 1868 & \ldots & \ldots & \ldots & \ldots & 45,395 \\ 1869 & \ldots & \ldots & \ldots & \ldots & 18,834 \\ 1870 & \ldots & \ldots & \ldots & \ldots & 14,878\end{array}$

If we take the weight of coral imported, we notice great 
fluctuations in the annual quantity received. The following are the comparativę annual figures:-

\begin{tabular}{|c|c|c|c|c|c|}
\hline 1855 & $\ldots$ & $\cdots$ & $\ldots$ & $\ldots$ & $4, \mathrm{I} 75$ \\
\hline 1856 & $\ldots$ & $\ldots$ & $\ldots$ & $\ldots$ & I6,358 \\
\hline 1857 & $\ldots$ & $\ldots$ & ... & $\ldots$ & 2,118 \\
\hline 1858 & $\ldots$ & $\ldots$ & $\ldots$ & $\ldots$ & 2,882 \\
\hline 1859 & $\ldots$ & ... & $\ldots$ & $\ldots$ & 4,831 \\
\hline 1860 & $\ldots$ & ... & ... & $\ldots$ & 3,105 \\
\hline I861 & $\ldots$ & $\ldots$ & $\ldots$ & $\ldots$ & 16,385 \\
\hline 1862 & $\ldots$ & $\ldots$ & $\ldots$ & $\ldots$ & 2,742 \\
\hline 1863 & $\ldots$ & $\ldots$ & $\ldots$ & $\ldots$ & I, 087 \\
\hline 1864 & $\cdots$ & $\cdots$ & $\ldots$ & $\ldots$ & 4,821 \\
\hline 1865 & $\ldots$ & $\ldots$ & $\ldots$ & $\ldots$ & $3,5^{6} 3$ \\
\hline 1866 & $\ldots$ & ... & $\ldots$ & $\ldots$ & 4,947 \\
\hline 1867 & $\ldots$ & $\ldots$ & ... & $\ldots$ & 7,879 \\
\hline 1868 & $\ldots$ & $\ldots$ & ... & $\ldots$ & 8,106 \\
\hline 1869 & $\ldots$ & $\ldots$ & $\ldots$ & $\ldots$ & 6,529 \\
\hline 1870 & $\ldots$ & $\ldots$ & $\ldots$ & $\ldots$ & 2,670 \\
\hline
\end{tabular}

The Indian trade in coral in 1875 shows a very slight decrease on that of $1873-74$, when it amounted to $£ 66,689$; but it is slowly recovering from the depression of previous years, that depression having, it is believed, been partly caused by the imposition of a duty of $7 \frac{1}{2}$ per cent. in April, 1870. The value of the imports was as follows :-

\begin{tabular}{|c|c|c|c|c|c|}
\hline 1868-69 & ... & $\ldots$ & $\ldots$ & $\ldots$ & $£ 93,126$ \\
\hline $1869-70$ & $\ldots$ & $\ldots$ & $\ldots$ & $\ldots$ & 65,285 \\
\hline I $870-7$ I & $\ldots$ & $\ldots$ & $\ldots$ & $\ldots$ & $45,44 \mathrm{I}$ \\
\hline $1871-72$ & $\ldots$ & $\ldots$ & $\ldots$ & $\ldots$ & 54,894 \\
\hline $1872-73$ & $\ldots$ & $\ldots$ & $\ldots$ & $\ldots$ & 40,013 \\
\hline I873-74 & $\ldots$ & $\ldots$ & $\ldots$ & $\ldots$ & 66,689 \\
\hline I $874-75$ & $\ldots$ & $\ldots$ & $\ldots$ & $\ldots$ & $53,55^{8}$ \\
\hline
\end{tabular}

Though the imposition of the duty probably had an immediate effect in reducing the importations, it must be remarked that the trade is of a variable and fluctuating nature. It is mainly in the hands of a few foreign firms, from whom natives purchase the coral for sale in the interior at great fairs and religious gatherings. Coral forms 


\section{The Commercial Products of the Sea.}

a favourite adornment for native children, as well as for adults, in certain classes of the population. The demand for coral depends upon the out-turn of the crops of the year. After an abundant harvest rupees will be freely exchanged for a string of corals to be added to those already worn as a necklace, but in a poor year the coral merchant will find his stock almost unsaleable at any price, and his next importations will consequently be on a very reduced scale.

Coral forms a large item of the Indian exports to Thibet. The preference is for round grains pierced, or oval grains with the ends truncated and pierced through the length. A piece as large as a pea fetches its weight in gold, and the price augments with the size. The darkest colours are the most esteemed.

In China coral constitutes an important article of trade. Various sorts are imported from Singapore, Sumatra, and the Samar Islands. Red coral is termed shan-hu, the white variety shih-hwa, but the black is more esteemed than any other colour. This is wrought into official buttons and beads, the inferior kinds being made into ear and finger rings. It is powdered and used there in medicine and in ophthalmia. Various madrepores and polypes have also a medicinal reputation in China.

A bank of coral of great richness is stated to have been discovered on the coasts of Japan. The coral collected is said to possess this peculiarity, that it is white in the centre and at all the lateral points, which are numerous on the branches. It is not, however, likely to prove useful for working up, as it appears to scale or break off. But a small quantity has yet been brought up. The principal fishery was to commence shortly, when more information will be obtained, but it does not appear likely to compete with the coral fished from the coasts of Italy and Sicily. 


\section{$(463)$}

\section{CHAPTER VI.}

AMBER AND THE AMBER FISHERIES.

Source of amber-Chemical composition of the resin-Uses and applicationStatistics of imports-Diving and fishing for amber-Prussian coasts of the Baltic the chief source of supply-Statistics of the trade-Large specimens found-Roumanian amber.

HAVING dealt with tortoise-shell, mother-of-pearl, pearls, and coral, we come now to consider a product of a somewhat amphibious character, and which, unlike those already treated of, is vegetable in its origin. Still it is largely dredged and fished for on the seashores, and as the greater part is obtained from the sea, it properly comes under the section of "Marine Contributions to Art."

Amber is a resinous exudation from an extinct species of conifer, called by Goppert Pinites succinifer. The source of amber was long uncertain; by some it was considered a carbonaceous mineral.

Professor Zaddach shows that the trees which yielded the amber must have grown upon the greensand beds of the cretaceous period, flourishing luxuriantly on the marshy coast which then surrounded the great continent of Northern Europe. Probably the temperature was much higher than it is now; and this even at that epoch extended to the now frost-bound Arctic regions, a fact 


\section{The Commercial Products of the Sea.}

which has been proved by the remarkable plant-remains of temperate climes which have been recently discovered there. The amber flora of the Baltic area under review contains northern forms associated with plants of more temperate zones; thus camphor-trees (Cinnamomum) occur with willows, birches, beech, and numerous oaks. A species of Thuya, very similar to the American Thuya occidentalis, is the most abundant tree amongst the conifers; next in abundance Widdringtonia, a great variety of pines and firs, including the amber-pine. Thousands of these, it is supposed by the professor, might have perished, and while the wood decayed, the resin with which the stem and branches were loaded might have been accumulated in large quantities, in bogs and lakes, in the soil of the forest. If the coast at that time was gradually sinking, the sea would cover the land, and in due course carry away the amber and masses of vegetable detritus into the ocean, where it was deposited amidst the marine animals which inhabit it. But in higher districts the amber-pine would still flourish, and so amber still continues to be washed into the sea and deposited in the later formed greensand and still later overlying formation of the brown coal.

Reboux states that at the eocene epoch the bed of the Baltic Sea was occupied by an immense forest, which spread over nearly the whole northern continent. Dredging carried on at a depth of 64 feet below the sea bottom has brought to light thereby two species of conifers, a poplar, a chestnut, and various other trees. From the conifers, the author thinks, ran the resin which, through being buried in the earth, has become changed into amber. The largest quantity of the gum appears to have been derived from the Pinus succimus. More than 200 specimens of objects have been found embedded in the gum, 


\section{Amber and the Amber Fisheries.}

including insects, reptiles, plants, leaves, grains, shells, fruit, etc.

The density of natural amber varies from I.09 to I.II. Its analysis, according to Schrotter, is : Carbon, 78.82 ; hydrogen, 10.23; oxygen, 10.90.

Amber is harder than most resins, and is susceptible of a good polish. It was known to the ancients, and called "electrum," on account of its electrical susceptibility; it was also engraved and used by the ancients for seals.

It occurs abundantly on the Prussian coast of the Baltic, from Dantzic to Memel. It is also found on the coast of Denmark and Sweden; in Gallicia, Poland, Moravia, the Ural ; Switzerland, near Basle ; France, near Paris; near London; in various parts of Asia, and in the greensand of New Jersey; also in Japan. It is chiefly obtained from Prussia, and is not very abundant in other countries.

With it are found fragments of lignite, and it frequently contains insects of extinct species embedded in its substance; it is also marked with the impression of branches and bark. It is sometimes thrown up in great quantities after storms. It contains a volatile oil, two resins (soluble in alcohol and ether), succinic acid, and an insoluble bituminous substance.

For ages amber has been valued for ornamental purposes, such as necklaces, bracelets, brooches, crosses, eardrops, silver links, and the like. It was also formerly much used for inlaying cabinets and ladies' jewel-cases, and a large picture frame inlaid with it was shown at the Naples Maritime Exhibition. The cloudy or milk-white amber, not that which is clear, is held in the highest esteem. The light-green variety, and that which is of one perfectly uniform colour throughout, are exceptions to this rule. 


\section{The Commercial Products of the Sea.}

The beauty and hardness of amber have caused it to be long esteemed by smokers for mouthpieces of pipes and tubes for cigar-holders. In the fine and extensive collection of pipes, etc., belonging to W. Bragge, Esq., shown at the London Exhibition, South Kensington, in I872, there were some very large amber mouth-pieces for hookahs, both clouded and clear; also in the case of Mr. F. Kapp, of 62, Dean Street, Soho. In Turkey, as much as $£ 300$ has been given for a very fine mouthpiece. I recently saw at the shop of Messrs. Phillips, Cockspur Street, a magnificent pair of amber tubes or mouth-pieces attached to hookahs.

The Turks esteem amber for mouthpieces, in the belief that no infectious disease can be communicated through it; the Germans now prefer it for its rich colour and its soft, waxy feeling in the mouth. Its value differs greatly, according to its tint and opacity, and herein a novice would be easily deceived. The bright yellow transparent amber is least valuable, however it may catch the eye. Dark, nearly opaque yellow has a much higher value, and the best of all is the opaque lemon-coloured. Mr. J. J. Jeans, the British vice-consul at Catania, showed at the Dublin International Exhibition in 1865 an amber necklace, consisting of $2 \mathrm{I}$ large flattened beads and 22 small ones. The ornament was of considerable mineralogical interest, the amber being found on the banks of the Simeto, a little river watering the plain of Catania. The specimen showed various colours of this rare substance-bright red, wine red, reddish yellow, and bluish.

According to recent accounts, one of the Shah of Persia's most esteemed talismans or amulets is a cube of amber reported to have fallen from heaven in Mahomet's time. It is worn round his neck, and is supposed to render 
him invulnerable. The small and waste pieces of amber form the base of an excellent varnish, and the source of succinic acid. The trade in amber to this country would appear to be largely on the increase. In the five years ending 1853 , our imports of rough amber averaged about 43 cwts. ; in 1867 they reached 60 cwts., and in 1870 had risen to 329 cwts. Besides this, we import a considerable quantity of manufactured amber in beads, mouthpieces, etc. The average annual value of the amber, as declared in the last six years, is about $£ 2,400$, but this is far below its real value. Amber beads, again, are mixed with the general item "Beads" in the official imports.

Amber often contains insects, flies, ants, spiders, etc., embedded in the resin, some of which are so delicately formed that they could not have been thus enclosed except in a fluid mass, such as a volatile oil or natural balsam. They eccur also frequently in the courbaril resin of South America, in Indian dammar and anime, and in copal from Accra, West Africa.

Amber is found in primary deposits on the coast of East Prussia. The amber-bearing stratum, which lies partly below the sea level, partly above, is a bluish-green colour, and consists of a coarse-grained sand, whose particles have a yellow coating. In this blue earth is found the amber to the amount of one kilogramme per 20 cubic feet. The pieces of amber found are generally weathered, but have retained their original shape, showing that the sea has had but little action on them. The colour is far from constant, being of all shades of yellow and brown.

The amber-dredging establishment at Schwarzort, on the Curish Haff (near to Memel), produces about 80,000 to $90,000 \mathrm{lbs}$. of amber every year, and is still in the hands of a Konigsberg firm, which keeps its transactions very secret. 


\section{The Commercial Products of the Sea.}

Four steam-dredges are employed for the collection of the amber, as well as a considerable number of dredges worked by hand. The amber is found almost uniformly in separate nodules, with lignite, disseminated in the sand, at a depth of from Io to 12 feet. The dredging is carried on day and night, by "shifts" of men, working eight hours each. About 400 persons are so employed, and their wages are, on the average, $2 s .6 d$. per shift. The quantity of amber collected is considerable, amounting to about $288 \mathrm{lbs}$. per shift, and for six days' work 51,184 lbs. The sand, after being dredged up, is sent on shore, where it is washed, in order to find the amber.

The method of obtaining amber from its ocean place of deposit in other parts is much on the principle of the ordinary submarine diving-dress. A woollen garment covers the entire body of the diver. This is again encompassed by an india-rubber dress, made in one piece, but differing in shape from the old-fashioned diving-dress, and allowing the diver to lie at full length. The helmet, also, is of a novel construction. Firmly fastened to it, and resting on the shoulders, is a small air-chest, made of sheetiron. This last is connected with the air-pump in the boat above by an india-rubber tubing, 40 feet long, and with the diver's lungs by another india-rubber tube, the mouthpiece of which is held by the diver between his teeth; the whole apparatus being scientifically arranged so as to admit a sufficient supply of pure air from above, and means of exit for the expired breath. The helmet is provided with three openings, covered with glass and protected by wire, for the use of the eyes and mouth. When this contrivance has been screwed on to the person of the diver, a rope tied round his waist, and half a hundred-weight of lead attached to his feet, shoulders, and helmet, he is ready for his plunge. Down, 
fathoms deep, he descends into the amber world. He stays there, maybe, for five hours at a time, hooking, dragging, tearing the amber from its bed with his heavy two-pronged fork. Often it resists his utmost efforts. However cold the weather may be, these men of. iron strength will come up from their submarine labours streaming with perspiration. The overseer stands in the boat to receive the amber from their pockets. In case he should wish to ascend before the usual time, the diver has to close his mouth and breathe five or six times through his nostrils, by this means filling the apparatus with air, which will bring him to the surface without other assistance.

The diving-boats are manned by eight men each-two divers, two pairs of men who work the air-pumps alternately, with their eyes fixed on a dial-plate, by which the supply of air is nicely indicated, one man to hold the safety-rope attached round the diver's body, and haul him at the slightest sign from below, and the overseer.

At the Vienna Exhibition, I873, some interesting diving apparatus was shown, as used on the eastern coast of Prussia, for obtaining amber. This apparatus, which received a gold medal at the Moscow Exhibition of 1872 , is constructed on the system of MM. Rouxquayrol-Denayroux ; some alterations and improvements having, however, been introduced, so as to give greater safety. The air is transmitted to the diver through long india-rubber tubes, by means of an easily transportable air-pump, with two cylinders. These tubes, which are strengthened by spiral wires, conduct the air to a regulator carried on the diver's back. The completely air and water tight dress of the diver is connected by an india-rubber ring with a copper helmet, or also with a mask, the helmet and mask being provided with strongly grated windows. The helmet is 


\section{The Commercial Products of the Sea.}

used for works under water in which the head of the diver has to be kept upright (repairing ships, for instance), while the mask is adopted for researches and examinations on the sea bottom.

A great advantage of this arrangement is that the diver has always a certain reserve quantity of air in the regulator, so that a falling off in the supply of air is not connected with immediate danger or disadvantages for him. The supply of air to the diver is regulated by a peculiarly constructed valve, by means of which the pressure, under which the air is supplied, corresponds always with the depth of the water in which the diver is acting.

The air coming from the diver is not allowed to mix with the fresh supply of air, but escapes to the surface through a side-port closed by an india-rubber valve. The diver is able to increase or diminish his specific weight by simply altering the volume of air between his dress and body; and, in this manner, it is in his power to ascend or descend as he likes.

Amber constitutes an important article of trade on the Dantzic coast, and it is exported, both in pieces and worked, to Austria, France, and the East. This trade is completely in the hands of a few families. The principal deposit is found on the coast of Samland, from Pillau to Gross Hubnicken. In this space of three miles the extraction of amber is farmed by the Government. The annual yield is about 200,000 lbs. The produce is classed into six qualities, according to the size and quality of the pieces.

The largest piece known is $13 \frac{3}{4}$ inches long by eight and a half inches wide, and three to six inches thick. It weighs I $3 \frac{1}{2}$ lbs., and is in the Berlin Museum. At the Great Exhibition of I85I, two pieces were shown, for beauty and 
size, from Konigsberg, weighing respectively four and a half and six pounds. In 1854 a bed of yellow amber of considerable extent was discovered at Prague, in sinking a well, and pieces weighing two and three pounds were extracted.

The trade in this article is annually increasing in importance, and as a very large part of all the amber appearing in the various markets of the world is supplied by the province of Prussia, including the neighbouring district of Memel, it may be interesting to give a short account of its appearance in that part of Germany.

Mr. Ward, the British vice-consul at Memel, in a recent official report, furnishes some full details as to the trade.

In the western portion of the province of Prussia amber is found, not only on the seashore, but also in the mountainous ranges of the interior. Excepting, however, in rare cases of its appearance in so-called "nests," amber is only to be met with in isolated pieces in the latter localities, so that the profit arising from the amber diggings amongst the hills is but a very moderate one, and may be estimated at about double the amount paid by the proprietors for the wages of the diggers. In East Prussia, however, and especially in that part called the Samland, amber is more abundant, and, during the prevalence of certain winds, is frequently thrown upon the shore by the sea in large quantities. It is collected there as well as fished for in the surf, as also dug out of the sand hillocks running along the seacoast. In these sand hillocks regular beds of amber are found enclosed in a soil of blue clay, which is to be met with at an average depth of about Ioo feet, in a thickness of 25 to 30 feet. It is stated that out of some diggings established in those parts, $4500 \mathrm{lbs}$. of amber were raised in the course of four months of the year I 869. 


\section{The Commercial Products of the Sea.}

Diggings of this kind exist at present in various spots of the Samland, more especially at Wanzen, Sassan, Groskuhren, Kleinkuhren, Kraxtepellen, Kreislacken, and Hubnicken. Besides these works there are other establishments at Brusterort, where amber is obtained by divers from the bottom of the sea, and at Schwarzort, near Memel, where it is raised by dredging for it at the bottom of the Curish Haff. Its importance and size have of late years increased considerably, and at present about $80,000 \mathrm{lbs}$. of amber are annually obtained by it.

The total amount of amber obtained during the year I 869 was about I50,000 lbs., the value of which may be taken at about $£ 82,500$. The quantity collected (by fishing for it) in the sea and upon the shore is about equal to that raised by the digging and dredging works. According to the opinion of competent persons, the produce of the diggings could be increased considerably by working them upon a regular mining system. Apart from the fact that no certain knowledge has hitherto been arrived at as to the actual extent of the amber-fields in the blue clayand these fields exist, most probably, not only in the vicinity of the seacoast, but also in the interior of the Samland, and even beyond that district and the frontiers of Eastern Prussia-it is most likely that below the stratum of clay to which the diggings are at present confined, there are other strata in which amber would be met with. This supposition is based upon the circumstance that considerable quantities of amber have been found amongst the soil washed away by the sea, during heavy gales, from shore portions of the coastal sand-hills which lie below the layer of blue clay first alluded to.

The prices of the principal kinds of amber are stated by an official report to be about as follows :- 


\begin{tabular}{|c|c|c|c|c|c|c|c|c|}
\hline I lb. & of 9 & pieces & s for pipe & mouthp & jieces & $\ldots$ & ... & $\begin{array}{l}s . \\
66\end{array}$ \\
\hline ", & I8 & ," & ," & ", & & $\ldots$ & ... & 45 \\
\hline , & 40 & ," & ," & , & & $\ldots$ & $\ldots$ & 30 \\
\hline , & 60 & ", & ," & , & & $\ldots$ & ... & 19 \\
\hline , & 100 & , & ", & ," & & $\ldots$ & $\ldots$ & 12 \\
\hline , , & 200 & ," & ," & ", & & $\ldots$ & $\ldots$ & 9 \\
\hline , & 30 & ", & beads & $\cdots$ & $\ldots$ & $\ldots$ & $\ldots$ & 30 \\
\hline ," & 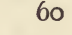 & ," & ", & $\ldots$ & $\cdots$ & $\ldots$ & $\ldots$ & I8 \\
\hline , & 100 & , & ", & $\cdots$ & $\ldots$ & ... & $\ldots$ & 12 \\
\hline
\end{tabular}

The prices of larger (so-called cabinet) pieces are subject to great fluctuations, and are fixed by the increase or decrease of demand from the East; and the prices of the commoner kinds seldom vary more than about io per cent.

The chief seat of the retail amber trade is Dantzic; the wholesale trade is at present in the hands of only two or three firms in the province of Prussia. The working of the Prussian amber into mouthpieces, beads, etc., is likewise carried on at Dantzic, but also in other large cities.

Amber is sent chiefly to Vienna, London, Paris, Moscow, and New York, in all of which cities the Prussian merchants keep agents, who are supplied with stocks of this article, assorted according to the requirements of the place. Great progress has lately been made with regard to the sorting of the various kinds of amber. There are now no less than 50 distinct kinds, differing in size, colour, hardness, and clearness. It is owing partly to this circumstance, and partly to the growing extent of the demand, that an increase in the sale of amber continues to take place. The demand from South Germany, Russia, the Danubian principalities, and the East in general, as compared with the comparatively limited amount hitherto obtainable, will, it is thought, prevent any increase of production from acting prejudicially on the gross profits of the trade in this article. 


\section{The Commercial Products of the Sea.}

Considering, moreover, the almost entire absence of mineral products in this part of Prussia, and the importance of opening additional channels of employment for the inhabitants, the Konigsberg Chamber of Commerce strongly recommends the introduction of the system above alluded to, by which the amber diggings might be extended, and worked upon a regular mining principle.

Amber is found in beds of lignite in various other countries, more particularly in the Adriatic, on the Sicilian shore.

In oriental commerce it is carried into India from Japan, the Philippines, and Madagascar. A considerable quantity of false amber, or copal, is imported into Canton annually, the imports averaging about $187 \mathrm{cwts}$. per quarter. The greater portion comes from the eastern coast of Africa. Its value in China was formerly very great for incense and for making ornaments. Transparent yellow pieces are considered the best by the Chinese; but the colour ranges from black and yellow through red and white. The price in the East, as here, varies according to size and quality.

In Prussia amber is divided into two classes, Fliesen and the Erd Bernstein; the former being found in water and the latter in mines. The Erd Bernstein amber is the most valuable, being hard and of a uniform colour.

Amber is manufactured at Trinley, a village within two miles of the English coast, and distant ten miles from Ipswich. It is there made into crosses, bracelets, and other personal ornaments, and one family has been engaged in it for the last 30 years. The amber is procured by poor persons, who pick it up after wintry storms on the coast between Landguard Fort and Aldeburgh. Mr. J. Wiggin, of Ipswich, has a piece four ounces in weight, procured from this source, and has also purchased many pounds of it at various times. 
The late Mr. D. Alexander's famous piece, said to be the largest in England, is believed to have been picked up in the same locality. Her Majesty the Queen has, I believe, a very fine large piece of amber.

There are many imitations of this beautiful resin, but none are so hard and enduring as the genuine article. The uninformed are, however, frequently deceived and taken in by pieces of anime, copal, or gum kowrie.

Mr. Consul Hertslet, in his report on the trade of Konigsberg for 1870 , stated that the production of amber was less than in former years-r4I 5 cwt., against I 7 IO cwt. in I869; and the war annihilated the trade with France for raw and manufactured amber. A demand came unexpectedly from China, but soon dropped again.

The dredging at Schwarzort brought 740 cwt.; the diving at Brusterort, 300 cwt.; the diggings in Samland, $55 \mathrm{cwt}$; the fishing, etc., along the coast, $320 \mathrm{cwt}$; total, I 4 I 5 cwt., of the estimated total value of 500,000 rix thalers.

The Prussian Amber Company Limited, Konigsberg, employs 2350 persons and I9 steam-engines in this trade, and sold in $187 \mathrm{I}$ amber, obtained by divers and dredging on the coasts of the Baltic, to the value of $£ 53,000$. A diploma of honour was awarded at the Vienna International Exhibition to this company for the extent of its trade and the excellence of its amber.

The extent of the amber-fields in Germany may be seen from the fact that 22 dredges, 2 tug-boats, IOO barges, and 1000 labourers are engaged in the industry. The area of the amber-field is extensive, and the Government derive from it a yearly rent of 72,200 thalers.

The trade, which had languished in 1868 and 1869 , regained much activity in I87I. England, France, and 
476 . The Commercial Products of the Sea.

Austria took large quantities in the rough state to be' worked up. The demands of Japan and China were also considerable, and the clear amber sought for by those countries became deficient, notwithstanding the development given to the extraction. They were not content with collecting amber formerly rejected on the shore. At Konigsberg, pits of 300 feet depth were dug; 500 workmen, steam-engines, and 100 carts were engaged in the works. In other localities, divers and drags were employed. At Munich steam-engines were also used to work the mud.

The production of amber in I874 amounted to 363,000 lbs., of all sizes and qualities, which was sent to different parts of the world.

C. A. Wisephal, manufacturer of articles of amber at Stolf, Pomerania, showed at the London Exhibition of I862 a fine set of opaque amber of the oriental style; a fine set of cut pale transparent amber; three strings of opaque beads for African trade, one, two, and three strings to the pound; 100 strings, assorted, valued at $£ 230$; two strings of transparent beads, eight strings going to the pound, at $£ 3$ per string; 19 other strings at $27 s$. the string; specimens of cigar-holders, pipe mouthpieces, etc., of different shapes and sizes; also transparent cut olive beads and transparent smooth beads.

Mr. F. Nissi, of Dantzic, showed four pieces of raw amber, one weighing $\mathrm{I}_{3} \mathrm{lb}$., priced at $£ \mathrm{I} 3$ IOs., and the others priced at $£ \mathrm{I} 3$ IOS., $£ \mathrm{I} 2$, and $£ 9$ I 5 s.

Mr. H. L. Perlbach, an amber-bead merchant of Dantzic, showed a rare piece of amber in point of size, form, and colour, three inches thick and 14 inches in circumference, weighing $12 \mathrm{lbs}$., valued at $£ 600$, and two pieces weighing four pounds and two pounds respectively. The large piece was found in an amber mine in the village of Gluckau, near Dantzic. 
Amber is found in the mountains of Sibicio, situated in the valley of Bugeo, Roumania. This amber is of a brown colour, with a great variety of shades, passing from orange yellow or red to black, with green tints. It is extracted in small quantities, and large pieces are rare. It is used for different objects of marquetry, the mouthpieces of pipes, beads for necklaces, and other small articles of luxury. The dust, or refuse, is used, when burned, to perfume rooms, the scent being very fragrant.

Roumanian amber differs totally from the German amber found on the shores of the Baltic. Sea. Both are the fossil resins of antediluvian trees, and agree in chemical composition, but differ in colour. German amber is found only of light colours-yellow, white, and pink-while Roumanian amber is red, pink, brown, blue, green, and black. These colours are frequently found mixed in a single piece, and we also have lumps with silver-coloured veins and gold specks. On account of this variety of colours, the Roumanian amber is highly esteemed, and the darker and more beautiful pieces are more costly than yellow amber, especially as they are more rare.

German amber is found in the sea or in alluvial earth; the Roumanian amber is only found in mountainous places and highlands, where it is sought and dug out by the peasants. The collection of amber there languishes, or, more properly speaking, is never conducted in a rational manner. The peasants being ignorant, and led only by instinct, dig here and there, wherever they guess that amber is to be found. Formerly, this amber was found in greater quantities, and also in much larger pieces than at present. If the search for amber and its collection were carried on in a scientific manner, by competent judges, it would prove remunerative.

North Burmah would seem to be rich in deposits of 
478 The Commeriial Products of the Sea.

amber. It is procured in its rough state by digging holes about three feet in diameter, and occasionally 40 feet in depth. The mines are at an elevation of about I050 feet, to the south-west of the Mein Khoom plain in the Hukong Valley. Fifteen to 20 feet of the superficial soil is clayey and red, the remainder consisting of a greyish-black carbonaceous earth. The amber is made into Buddhist rosaries, finger-rings, pipe mouthpieces, etc. The dark sherrycoloured amber is most highly valued there. 


\section{N DEX.}

A.

Agar-agar, 324, 325

Alva, uses of, 3 I 3

Amber, description of, 463

beads, 467

dredging and diving for, 468

in Burmah, 478

large blocks of, 470

relative prices of, 473

trade, Dantzic the chief seat of, 473

two classes of, 474

uses of, 465

Anchovies, exports from Norway, 2I

Anchovy fishery, 8I

French, 17

Artificial pearls, 266

Abalones, 399

\section{B.}

Baccalau, another name for klip-fish, 32

Bahamas sponge fisheries, 174

Balachong, 264 statistics of export, 177

Balolo, I 26

Basking shark, 229

Beadlemer seal, 202

Bèche-de-mer, 106

Beluga, or white whale, 208

Benitiers of shells, 293

Berried hen, definition of, 94

Black coral, 440 helmet shell, 275

Bladder-wrack, 3I 3

Bleaching sponges, 177
Blubber, 202, 205

Boalee fish, 257

Boat sponge, I 75

Bombay pearl shells, 377

Bounty, French, on fisheries, 4

Brainstone coral, $44^{\circ}$

Brazilian isinglass, 250

Bull's mouth shell, 273

Bultow fishing, definition of, 27

Burtah, definition of, 243

Byssus, uses of, 307

of pearl oyster, 389

C.

Cameo-cutting, 273

Capelin fishery, 127

Cape lobster, Ior

Colony, fisheries of, 15

Carrageen moss, 318

Carry-way, a kind of boat, 223

Cat-fish oil, 216

Caviare, value of the imports, 2 I

Cephalopods as food, II 6

Ceylon, imports of fish, 15 pearl fishery, statistics of, 409 , 410

Chank shells, 288

China fisheries, 16

Chinese isinglass, 253

Chunam or shell lime, 285

Clam shell, 28I

Clams, varieties of, 146

Classing and value of pearls, 425

Clovisses, 147

Cockle shells, uses of, 299 
Codfish, mode of catching, by handlines, set lines, and nets, 34 process of curing, 29

Cod fisheries, number of French vessels employed in, 39

Cod fishery, French, at Newfoundland, I7

Iceland, I7

of Ireland, 26

of Newfoundland, 26

of Scotland, quantity

Cod-liver oil, 213

$$
\text { cured, } 25
$$

Cod oil, 213

value of the imports, 2 I

Cod tongues and sounds, 31

Combou or kombou, 329, 334

Commercial products, variety obtained from the sea, I

Conch pearls, 408

shells, 273

Cones, uses of, 29.4

Coral, Algeria, 454

beads, $442,447,45^{6}$

classification of, 455

commercial varieties of, 443 .

composition of, 438

exports from Sardinia, 449

imports into England, 446

France, 445

United Kingdom, 460

Indian trade in, $46 \mathrm{I}$

value of the imports, 2 I

Coral fishery, $45^{\circ}$ boats employed in, $45^{8}$

Cornish sardines, 64

Cowries, African trade in, 269

as currency, $\mathbf{2 7 9}$

commercial uses of, 277

value of the imports, 21

Crab-pots, 93

Crabs, how sold, 93

in Norway, ror

Crin vegetal, 313

Crustaceans, 90

"Crown full," definition of, 47

Cummelmums, 264

Cup-shaped sponges, 168

Cuttle-fish dried, I16, 120

bone, 121
D.

Diving-bells for sponge fishing, I90

Diving for pearls, 427

for pearl shells in the Pacific, 386, 394

Dog-fish skins, 262

Drift-nets, 49

Dugong oil, 209

Dulse, 336

Dun-fish, 31

Dutch herring fishery, 54

Dyes from the mollusca, 303

E.

Ear-shells, 372, 398

Egyptian pearl shells, 378

F.

Fish as food, 9

bones, 257

fresh-water, sold in Paris, I8

flour, 264

guano, 154

hooks of shell, 297

inexhaustible supply of, 5

maws, eastern trade in, 256

number of species known, 3

oils, I53, 212

oil soap, 224

parts of, employed in arts and manufactures, 2

paste, 264

products and their uses, 257, 264

scales, uses of, 154

skins, uses of, I 53

supply to London, 7

value of imports in the United Kingdom, 2 I

Fish skin, applications of, 259 leather, 259

Fisheries, French, I 7

Irish, I2

of North America, I3

value of exports of British, II

statistics of those of foreign countries, $\mathbf{2 I}$ 
Fishery products, imports of, in $\mathbf{1 8 7 0}$, 21

French fisheries, value of, 17 herring fishery, 57 fishery, boats employed, I8

Fur seal, 203

\section{G.}

Gall of the carp used as a dye, 152

Galuchat, 263

Garoon shell, 286

Garum, 265

Gelose, or seaweed isinglass, 324, $327,328,335$

Gilbackre isinglass, 25I

Glove sponge, 159

Green snail shell of commerce, 293, 399

Grotto shells, 299

Guanine, 266

H.

Hake, $25 \mathrm{I}$

Halibut, 128

Hard head sponge, I75

Hard-shell clam, 146

Harp seal, 202

Helmet shells, 273

Herring brands, definitions of, 47 fishery of France, 56

of Holland, 54

of Norfolk, 47

of North America, $5^{8}$

of Norway, $5^{8}$

of Scotland, 43

oil, 218

Herrings, exports from Norway, 2 I statistics of cure and export from Scotland, 46 weight of, sent per Great

Hood seal, 202 Eastern, 5I

I.

Iceland fisheries, 36,38

Imports of the fisheries, statistics of, I I Indian fish oils, 216
Indian isinglass, 243

Iodine, 313

Isinglass, description and preparation of, 238

value of our imports, 21

J.

Japan seaweeds, 329

Ju-ka, 254

K.

Kabiljauw, 256

Kelp weed, 322

Keratosa, I6o

King-crab, 90

Kippered herrings, $5 \mathbf{I}$

Klipfish (dried cod), exports from Norway, 21

\section{L.}

Last of herrings, definition of, 52

Laver, 336

Leather from fish skins, 153

Lobster canning, or tins, 96

pots, 97

spawn, use of, 94

fishery in Norway, 99 of America, 95

Lobsters, curious names for, 92

British, 9I

exports from Norway, 2 I

statistics of exports from Norway, 100

Lofoden fisheries, 36

London, fish supply to, 7 , ro

Louar oil, 2I 7

\section{M.}

Maara shells, 387

Machorian isinglass, $25 \mathrm{I}$

Mackerel, commercial classification of, 72

fishery, British, 67

French, 17, 68

North American, 69

Norway, 68 
Madrague, definition of, 89

Madrepore for paving and building, 152

Manatus, 209

Manila pearl shells, 378,385

Marine salt, 339 silk, 306

Matanza, definition of, 86

Maties, definition of, 47

Medicinal uses of shells, 302, 303

Menhaden fish preserved in oil, 8I oil, 221

Moss-bunker, or menhaden, $8 \mathbf{I}$

Mother-of-pearl, applications of, in China, 397 articles made of, $37 \mathrm{I}$ British imports, 382

Mother-of-pearl shells, commercial varieties of, 377 from Western Australia, 395

value of our imports, 21

Mussel fishery of France, 18 shells, uses of, 298

\section{N.}

Nautilus shells, 296, 30I

Nets, size and kind of, 49

Newfoundland cod fishery, 26

Norfolk herring fishery, 48

North American fisheries, I3, I4 herring fishery, 58

Norway cod fishery, 32

$$
\text { isinglass, } 25 \mathrm{I}
$$

Nuoc-mam, 265

$$
\text { herring fishery, } 58
$$

\section{O.}

Octopods, II 7

Oils, fish, I 53

from marine mammals, 198

Opercula, uses of, 302

Orchella weed, value of the imports, 2 I

Organ-pipe coral, 440

Ormer shell, 398

Ottoman sponge fishery, 183

Oolachan oil, 154, 219

Oyster fisheries, American, I 39

British, I3 I
Oyster fisheries of France, 18, 135, 138

Oysters of Australia, I44

P.

Painter's mussel, 269

Paires doubles, 147

Palolo, I2I

Panama pearl fishery, 420

pearl shells, 378

Papier-mâché work, 3\$1, 400

Paris, consumption of fish in, 19

Pearl buttons, 372

of oysters in, I35

Pearl fisheries, 402

of Western Australia, 427

of Persian Gulf, 418

of Ceylon, 409

of Panama, 420

Pearl inlaying, $38 \mathbf{I}$

mussel, Chinese, 4I I

Pearls, commerce in, in England, 403 classification of, 417 imported into France, 418

from Labuan, 424

from Pacific Islands, 424

quantities of, 405

used by the North American

Indians, 420

value of the imports, 21,418

various colours of, 405

Pilchard fishery, 60

Pilchards cured in oil as sardines, 64 statistics of catch and exports, 63

Pilgrim shells, 398

Pink pearls, 408

Piracuru fish, 250

Poggies, a kind of fish bait, 7 I

Polypi, I 7

Pomfret, I 30

Porgy, a name for the menhaden fish, 221

Porpoise oil, 208

Prussian amber, 465

Q.

Queen conch shell, 273, 293 
$\mathrm{R}$.

Rau-cau, 325

Ray skin, 262

Razor clam, 146

Reef or fine toilet sponge, I75

Ribbon isinglass, $25 \mathrm{I}$

River pearls, 428

Rouen oil, I 54

Roumanian amber, 477

Round clam, 146

Russian isinglass, 24I

S.

Saddle Rock oyster, 142

Salmon, aggregate value of British and Irish fisheries, 74

as food, 6

in British Columbia, 76

statistics of London sales, 74

Salmon fishery, 73

in New Brunswick, 75

in Norway, 75

Salt in Australia, 348

in Austria, 344

in California, 344

in Cochin China, 347

in India, 346

in Portugal, 345

in the United States, 344

manufacture in France, 339

Sandre oil, 215

Sankka or shell bracelet, 291

Sardine fishery of France, 17, 77 oil, 217

Sardines, American, 81

Sawfish, oil from, 216 used as manure in Japan, 8r

Scabeccio, definition of, 87

Scales of fish, usees of, 258

Scallop shells, uses of, 298

Scotch pearls, 429

Seal fishery, I99

$$
\text { oil, } 290
$$

Seal skins, 202

exported from Norway, 2I value of the imports, 2 I

Sea-urchins, I2 I

Seaweed and its uses, 3 II

collection of, in France, 317 in Japan, 3I 7
Seaweed for manure, 314

Seer-fish, I 30 as food, $32 \mathrm{I}$

Seine nets, 62

Sephen skin, 262

Sepia, 303

Shad fishery in North America, 60

Shagreen, 263

Shank or chank shell, 289

Shark skin, 26r

Shark fins, 235, 237 fishery, 226

Sharks, varieties of, 226

Sheep-wool sponge, 176

Shell bangles or bracelets, 288 cameos, 274

fish-hooks, 297 sand, 285

Shells as currency, 278, 28I calcined, 270 composition of, 268 domestic uses of, 297 sales of, in London, 27 I useful applications of, 270 value of British imports; 287

Shrimp fishery, English, 102

Shrimps, dried, trade in, 104

Silicious sponges, 194

Singapore, imports of fish, 15

Slips, a name for soles, I 29

Snoods, definition of, 27

Soles, I 29

South Sea pearl shells, 377

Spent fish, definition of, 47

Spermaceti or head matter, 205

Sponge, chemical analysis of, 178 descriptions of, 155

fishery of Tunis, I90

for stuffing beds, 178

value of imports, 2 I

Sponge fisheries, American, I70 of the Bahamas, 174

Sponges, commercial grades of, 159 cultivation of, 182

French classification of, 193 imports of, from the Mediter. ranean, 192

scientific divisions of, $15^{6}$

Soft clam, 146

of the Mediterranean, 183

Spring herrings, 52

Squids for fish bait, 120

Stock-fish or round-fish, 32 
Sturgeon, 240, 253

Suleah fish, 243

Sulu pearl shells, 377

Swordfish, 118

$$
\text { T. }
$$

Tangle, 336

Tiger cowry, 279

Tinned lobsters, 96

Tongues, a name for soles, I 29

Tortoiseshell boats, 360

$$
\text { combs; } 35^{\circ}
$$

British imports, 363

description of, $35 \mathrm{I}$

imports into France, 364 manufacture, 354

value of the imports, 2 I

Train oil and blubber, 205

$$
\text { exported from Norway, } 21
$$

Trawlers, number of, in the British

- seas, 8

Tree oysters, $42 \mathrm{I}$

Trepang fishery, I05 mode of curing, 112 varieties of, I07, I08, II4

Trumpet shells, 286, 299

Turbo shells, 300

Turk's cap shell, 294, 400
Tunny fishery, 83 oil, 85,218

Turbot, 130

Turtle, edible or green, 364

Turtle eggs, 368 modes of cooking, 366

Tuticorin pearl fishery, $4 \mathrm{I} 3$

Tyrian purple, 304

V.

Velvet sponge, 175

Venetian shells, 277

Vesiga, definition of, 242

Vog, definition of, 36

W.

Walrus, 204

Wampum, 28I

Whalebone or fins, imports of, 206

Whale fishery, 204 or train oil, value of imports, 21

Western Australian pearl fishieries, 427

West Indian isinglass, 25 L $^{\circ}$

Wool sponge, I59 . - : 

THIS BOOK IS DUE ON THE IAST DATE than

\section{STAMPED BELOW}

AN INITIAL FINE OF 25 CENTS WILL BE ASSESSED FOR FAILURE TO RETURN THIS BOOK ON THE DATE DUE. THE PENALTY WILL INCREASE TO 50 CENTS ON THE FOURTH DAY AND TO \$1.00 ON THE SEVENTH DAY OVERDUE.

APR 211933

$24 ; n^{\prime} 581 W$

JAN 201948

NOV 211990

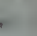




\section{UNIVERSITY OF CALIFORNIA LIBRARY}




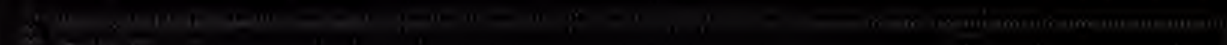

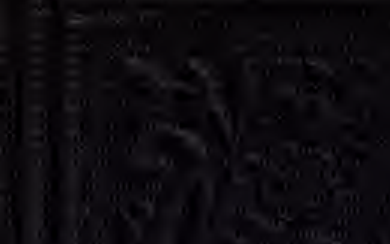

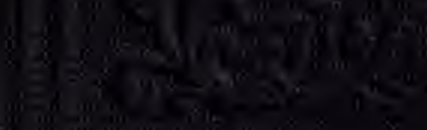

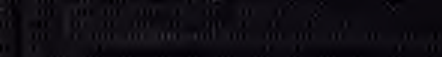

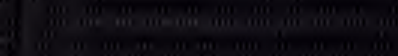

in in

8 !

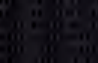

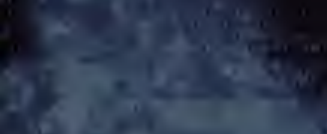

$x^{2}$

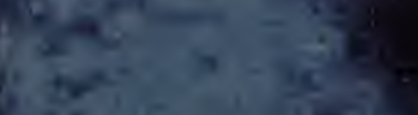

1. 1

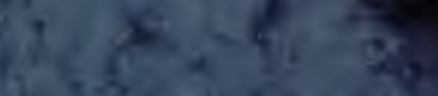

